\title{
Type studies on Parmotrema (Parmeliaceae, Ascomycota) with salazinic acid
}

\author{
Adriano Afonso Spielmann ${ }^{1}$ \& Marcelo Pinto Marcelli²
}

\section{Article info}

Received: 6 Aug. 2020

Revision received: 17 Nov. 2020

Accepted: 23 Nov. 2020

Published: 29 Dec. 2020

Associate Editor

Alice Gerlach

\begin{abstract}
The species of Parmotrema with salazinic acid were revised, based on the types of the accepted names, as well as their synonyms. Descriptions for 66 species are given and the synonymy, chemistry, distribution and taxonomic affinities of each species discussed. Three new species are described: Parmotrema austromaculatum sp. nov., P. bifidum sp. nov. and $P$. clercianum sp. nov. One new combination in Parmelinella is made, P. afrocetrata comb. nov., as well as 13 new combinations in Parmotrema: P. acanthifolium comb. nov., P. concors comb. nov., P. foliolosum comb. nov., P. granulare comb. nov., P. lividotessellatum comb. nov., P. magnum comb. nov., P. maximum comb. nov., P. nudum comb. nov., $P$. petropoliense comb. nov., $P$. radiatum comb. nov., $P$. reterimulosum comb. nov., $P$. sieberi comb. nov. and $P$. warmingii comb. nov. One new name, Parmotrema elixii nom. nov. is proposed for Rimelia pustulata. Two lectotypifications are made: Parmotrema erubescens and P. ruminatum. Twelve taxa remain without definite status and are included in the nomina inquirenda.
\end{abstract}

Key words: lichens, Brazil, Parmelia, Rimelia, Canomaculina, Rimeliella, Parmelinella.

\section{Introduction}

Our previous inventory of Parmeliaceae from the Central Rio Grande do Sul (Spielmann 2005; Spielmann \& Marcelli 2009) pointed out the existence of a cosmopolitan assembly of lichenized fungi with complex taxonomic problems, constituted by species of Parmotrema and the formerly separated genera Canomaculina, Rimelia and Rimeliella that shared the common feature of the presence of medullar salazinic acid. The latter genera were proposed as synonyms of Parmotrema by Blanco et al. (2005) and these taxa are currently called 'parmotremoid lichens'.

The initial goal was to accomplish a revision of the species recorded from São Paulo, Brazil, and later work on the revision for all the Brazilian species. Nevertheless, we soon realized that the taxonomic and nomenclatural problems involved affected all known species of parmotremoid lichens with salazinic acid, including their synonyms. Since the first step in a monographic revision is to determine the correct application of the species names, we focused this study primarily on the types of the accepted names, as well their synonyms.

\footnotetext{
${ }^{1}$ Laboratório de Botânica, Instituto de Biociências, Universidade Federal de Mato Grosso do Sul, CEP 79070-900, Campo Grande/MS, Brazil

2 Instituto de Botânica, Núcleo de Pesquisa em Micologia, Caixa Postal 68041, CEP 04045-972, São Paulo/SP, Brazil

* Corresponding author e-mail: adriano.spielmann@ufms.br
}

\section{Generic delimitation}

In the following historical account, the emphasis was placed on those authors who proposed new names, new combinations and new species. Floras, lists and non-taxonomic literature were not included, except when necessary. The new and invalid names, new combinations and synonyms proposed are chronologically organized in Table 1.

\section{Parmotrema A. Massal.}

The history of parmotremoid lichens starts with the proposition of the genus Parmotrema (Massalongo 1860), which was based on one species of Parmelia, namely Parmelia perforata. The main generic character used by Massalongo was the presence of perforated apothecia (from the Latin parmo = shield, trema: hollow), at that time known only from that species. However, Parmotrema was not widely accepted. In fact, in the first detailed paper on Brazilian Parmeliaceae, Vainio (1890) used the name Parmelia, never mentioning the genus Parmotrema. On the other hand, Vainio's section Amphigymnia within Parmelia corresponded very well to Massalongo's concept of Parmotrema, as evidenced by Zahlbruckner (1907).

Later, Dodge (1959) raised Amphigymnia to the status of subgenus, the level used by Hale (1965) in his classic world monograph on the group. Meanwhile, few lichenologists (e.g. Choisy 1931, 1952; Dodge \& Baker 1938) used the name Parmotrema. 
Table 1. Chronological list of the species of parmotremoid lichens with salazinic acid.

\begin{tabular}{|c|c|c|c|}
\hline Year & Name & Name in the literature & Present paper \\
\hline 1803 & Parmelia perlata var. olivaria Ach. & Parmotrema pseudoreticulatum & Parmotrema pseudoreticulatum \\
\hline 1805 & Lichen perlatus $\alpha$ ciliatus Lam. \& DC & Parmotrema reticulatum & nomen inquirendum ${ }^{*}$ \\
\hline 1814 & Parmelia cetrata Ach. & Parmotrema cetratum & Parmotrema cetratum \\
\hline 1825 & Parmelia polita Fr. & Parmotrema cetratum & nomen inquirendum \\
\hline 1826 & Parmelia acanthifolia Pers. & Parmotrema cetratum & Parmotrema acanthifolium \\
\hline 1826 & Parmelia badia Pers. & Parmotrema cetratum & nomen inquirendum \\
\hline 1826 & Parmelia maura Pers. & Parmotrema cetratum & nomen inquirendum \\
\hline 1836 & Parmelia reticulata Taylor & Parmotrema reticulatum & Parmotrema reticulatum \\
\hline 1837 & Parmelia latissima Fée & Parmotrema latissimum & Parmotrema latissimum \\
\hline 1843 & Parmelia perforata var. ulophylla Meyen \& Flotow & Parmotrema cristiferum & Parmotrema cristiferum \\
\hline 1843 & Parmelia perforata var. replicata Meyen \& Flotow & Parmotrema cetratum & nomen inquirendum \\
\hline 1847 & Parmelia cristifera Taylor & Parmotrema cristiferum & Parmotrema cristiferum \\
\hline 1847 & Parmelia stuppea Taylor & Parmotrema stuppeum & Parmotrema stuppeum \\
\hline 1869 & Parmelia glaberrima var. flavescens Kremp. & Parmotrema flavescens & Parmotrema flavescens \\
\hline 1869 & Parmelia subsumpta Nyl. & Parmotrema subsumptum & Parmotrema subsumptum \\
\hline 1873 & Parmelia angustata Kremp. & Parmotrema cetratum & Parmotrema warmingii \\
\hline 1873 & Parmelia perforata var. corniculata Kremp. & Parmotrema cetratum & Parmotrema cetratum \\
\hline 1874 & Parmelia subcaperata Kremp. & Parmotrema subcaperatum & Parmotrema subcaperatum \\
\hline 1877 & Parmelia hildebrandtii Kremp. & Parmotrema cristiferum & Parmotrema cristiferum \\
\hline 1877 & Parmelia erubescens Stirt. & Parmotrema erubescens & Parmotrema erubescens \\
\hline 1877 & Parmelia reparata Stirt. & Parmotrema reparatum & Parmotrema reparatum \\
\hline 1880 & Parmelia urceolata var. nuda Müll. Arg. & Parmotrema subsumptum & Parmotrema subsumptum \\
\hline 1881 & Parmelia concors Kremp. & Parmotrema reticulatum & Parmotrema concors \\
\hline 1883 & Parmelia urceolata var. subcetrata Müll. Arg. & Parmotrema reticulatum & Parmotrema clavuliferum \\
\hline 1886 & Parmelia praeperlata Nyl. & Parmotrema reticulatum & Parmotrema reticulatum \\
\hline 1886 & Parmelia virens Müll. Arg. & Parmotrema reparatum & Parmotrema reparatum \\
\hline 1886 & Parmelia virens var. sorediata Müll. Arg. & Rimelia reticulata & Parmotrema subsumptum \\
\hline 1890 & Parmelia delicatula Vain. & Parmotrema delicatulum & Parmotrema delicatulum \\
\hline 1890 & Parmelia cetrata f. sorediifera Vain. & Parmotrema reticulatum & nomen inquirendum \\
\hline 1890 & Parmelia warmingii Vain. & Parmotrema cetratum & Parmotrema warmingii \\
\hline 1891 & Parmelia hildebrandtii f. sorediosa Müll. Arg. & Parmotrema cristiferum & Parmotrema cristiferum \\
\hline 1891 & Parmelia mesotropa f. sorediosa Müll. Arg. & Parmotrema cristiferum & Parmotrema cristiferum \\
\hline 1891 & Parmelia cetrata var. corniculata (Kremp.) Müll. Arg. & Parmotrema cetratum & Parmotrema cetratum \\
\hline 1892 & Parmelia virens f. isidiosa Müll. Arg. & Parmotrema subtinctorium & Parmotrema subtinctorium \\
\hline 1894 & Parmelia cetrata var. subisidiosa Müll. Arg. & Parmotrema subisidiosum & Parmotrema subisidiosum \\
\hline 1899 & Parmelia eurysaca Hue & Parmotrema eurysacum & Parmotrema eurysacum \\
\hline 1899 & Parmelia hypotropa var. imperialis Hue & Parmotrema subsumptum & Parmotrema subsumptum \\
\hline 1899 & Parmelia imperforata Nyl. & Parmotrema subcaperatum & Parmotrema subcaperatum \\
\hline 1899 & Parmelia leucosemotheta Hue & Parmotrema leucosemothetum & Parmotrema leucosemothetum \\
\hline 1899 & Parmelia leucosemotheta f. isidiata Hue & Parmotrema subtinctorium & Parmotrema subtinctorium \\
\hline 1899 & Parmelia lividotessellata Hue & Parmotrema reticulatum & Parmotrema lividotesselatum \\
\hline 1899 & Parmelia margaritata Hue & Parmotrema margaritatum & Parmotrema margaritatum \\
\hline 1899 & Parmelia mauriensis Hue & Parmotrema flavescens & Parmotrema flavescens \\
\hline 1899 & Parmelia maxima Hue & Parmotrema stuppeum & Parmotrema maximum \\
\hline 1899 & Parmelia reticulata f. nuda Hue & Parmotrema reticulatum & Parmotrema nudum \\
\hline 1902 & Parmelia petropoliensis Zahlbr. & Parmotrema subsumptum & Parmotrema petropoliense \\
\hline 1904 & Parmelia subcaperata f. ciliata Zahlbr. & Parmotrema delicatulum & Parmotrema delicatulum \\
\hline 1906 & Parmelia herrei Zahlbr. & Parmotrema cetratum & Parmotrema herrei \\
\hline 1909 & Parmelia claudelii var. clemensae Vain. & Parmotrema cristiferum & Parmotrema sieberi \\
\hline 1909 & Parmelia protoflavescens Zahlbr. & Parmotrema flavescens & Parmotrema flavescens \\
\hline 1909 & Parmelia pseudoflavescens Zahlbr. & Parmotrema flavescens & Parmotrema flavescens \\
\hline 1914 & Parmelia cetrata subsp. radiata Lynge & Parmotrema cetratum & Parmotrema radiatum \\
\hline 1914 & Parmelia magna Lynge & Parmotrema delicatulum & Parmotrema magnum \\
\hline 1914 & Parmelia moreliensis B. de Lesd. & Parmotrema moreliense & nomen inquirendum \\
\hline 1914 & Parmelia nylanderi Lynge & Parmotrema nylanderi & Parmotrema nylanderi \\
\hline 1914 & Parmelia radians Lynge & Parmotrema delicatulum & Parmotrema delicatulum \\
\hline 1914 & Parmelia rupta Lynge & Parmotrema ruptum & Parmotrema ruptum \\
\hline 1918 & Parmelia cetrata var. sorediifera f. platyloba Vain. & Parmotrema reticulatum & nomen inquirendum \\
\hline 1926 & Parmelia reterimulosa J. Steiner \& Zahlbr. & Parmotrema reticulatum & Parmotrema reterimulosum \\
\hline 1928 & Parmelia velutina Zahlbr. & Parmotrema subtinctorium & nomen inquirendum \\
\hline 1930 & Parmelia corrugis var. imperialis (Hue) Zahlbr. & Parmotrema subsumptum & Parmotrema subsumptum \\
\hline 1930 & Parmelia perforata var. ciliata Sambo & Parmotrema uruguense & nomen inquirendum \\
\hline
\end{tabular}


Table 1. Continued.

\begin{tabular}{|c|c|c|c|}
\hline Year & Name & Name in the literature & Present paper \\
\hline 1930 & Parmelia subtinctoria Zahlbr. & Parmotrema subtinctorium & Parmotrema subtinctorium \\
\hline 1931 & Parmelia pseudovirens Gyelnik & Parmotrema reticulatum & Parmotrema subsumptum \\
\hline 1931 & Parmelia protovirens Gyelnik & Parmotrema subtinctorium & nomen inquirendum \\
\hline 1934 & Parmelia cristifera f. cinerata Zahlbr. & Parmotrema cristiferum & nomen inquirendum \\
\hline 1939 & Parmelia leucoxantha f. firma Sambo & Parmotrema subsumptum & Parmotrema subsumptum \\
\hline 1940 & Parmelia cetrata f. granularis Asahina & Parmotrema reticulatum & Parmotrema granulare \\
\hline 1944 & Parmelia clavulifera Räsänen & Parmotrema clavuliferum & Parmotrema clavuliferum \\
\hline 1944 & Parmelia ramescens Zahlbr. & Parmotrema ramescens & Parmotrema ruminatum \\
\hline 1944 & Parmelia ruminata Zahlbr. & Parmotrema ruminatum & Parmotrema ruminatum \\
\hline 1945 & Parmelia pseudoreticulata Tavares & Parmotrema pseudoreticulatum & Parmotrema pseudoreticulatum \\
\hline 1947 & Parmelia cinerascens var. saxicola Räsänen & Parmotrema cetratum & nomen inquirendum \\
\hline 1947 & Parmelia perforata var. microspora Räsänen & Parmotrema cetratum & nomen inquirendum \\
\hline 1959 & Parmelia foliolosa C.W. Dodge & Parmotrema reticulatum & Parmotrema foliolosum \\
\hline 1959 & Parmelia gossweileri C.W. Dodge & Parmotrema cristiferum & nomen inquirendum \\
\hline 1959 & Parmelia imerinensis C.W. Dodge & Parmotrema cristiferum & nomen inquirendum \\
\hline 1959 & Parmelia menziesii C.W. Dodge & Parmotrema cetratum & nomen inquirendum \\
\hline 1959 & Parmelia sieberi C.W. Dodge & Parmotrema cristiferum & Parmotrema sieberi \\
\hline 1960 & Parmelia microdactyla Hale & Parmotrema delicatulum & Parmotrema magnum \\
\hline 1965 & Parmelia coralliformis Hale & Parmotrema coralliforme & Parmotrema coralliforme \\
\hline 1965 & Parmelia miranda Hale & Parmotrema mirandum & Parmotrema mirandum \\
\hline 1965 & Parmelia ramuscula Hale & Parmotrema ramusculum & Parmotrema ramusculum \\
\hline 1971 & Parmelia permaculata Hale & Parmotrema permaculatum & Parmotrema permaculatum \\
\hline 1973 & Parmelia parahypotropa W.L. Culb. & Parmotrema parahypotropum & Parmotrema parahypotropum \\
\hline 1974 & Parmelia spinibarbis Kurok. & Parmotrema spinibarbe & Parmotrema spinibarbe \\
\hline 1974 & Parmelia ultralucens Krog & Parmotrema ultralucens & Parmotrema ultralucens \\
\hline 1977 & Parmotrema concurrens Hale & Parmotrema concurrens & Parmotrema concurrens \\
\hline 1977 & Parmotrema enteroxanthum Hale & Parmotrema enteroxanthum & Parmotrema enteroxanthum \\
\hline 1977 & Parmotrema expansum Hale & Parmotrema expansum & Parmotrema expansum \\
\hline 1977 & Parmotrema neotropicum Kurok. & Parmotrema neotropicum & Parmotrema neotropicum \\
\hline 1977 & Parmotrema reitzii Hale & Parmotrema reitzii & Parmotrema reitzii \\
\hline 1979 & Parmotrema masonii Ferraro & Parmotrema masonii & Parmotrema masonii \\
\hline 1981 & Parmotrema paramoreliense W.L. Culb. \& C.F. Culb. & Parmotrema paramoreliense & Parmotrema paramoreliense \\
\hline 1987 & Canomaculina tandilensis Adler \& Elix & Parmotrema tandilense & Parmotrema tandilense \\
\hline 1987 & Canomaculina ventanica Adler \& Elix & Parmotrema ventanicum & Parmotrema ventanicum \\
\hline 1988 & Parmotrema austrocetratum Elix \& Johnston & Parmotrema austrocetratum & Parmotrema austrocetratum \\
\hline 1990 & Parmotrema mantiqueirense Hale & Parmotrema mantiqueirense & Parmotrema mantiqueirense \\
\hline 1992 & Parmotrema verrucisetosum Sipman & Parmotrema verrucisetosum & Parmotrema verrucisetosum \\
\hline 1993 & Rimeliella cristobaliae Ferraro \& Elix & Parmotrema cristobaliae & Parmotrema cristobaliae \\
\hline 1997 & Parmotrema lichexanthonicum Eliasaro \& Adler & Parmotrema lichexanthonicum & Parmotrema lichexanthonicum \\
\hline 1998 & Rimelia pontagrossensis Eliasaro \& Adler & Parmotrema pontagrossense & Parmotrema pontagrossense \\
\hline 2000 & Canomaculina laciniella Ferraro \& Elix & Parmotrema laciniellum & Parmotrema laciniellum \\
\hline 2001 & Parmotrema acutatum Kurok. & Parmotrema acutatum & Parmotrema acutatum \\
\hline 2001 & Parmotrema despectum Kurok. & Parmotrema despectum & Parmotrema despectum \\
\hline 2001 & Rimelia albinata K.H. Moon, Kurok. \& Kashiw. & Parmotrema albinatum & Parmotrema albinatum \\
\hline 2002 & Rimelia pustulata Elix \& Bawingan & Parmotrema pustulatum & Parmotrema elixii \\
\hline 2005 & Parmotrema afrocetratum Elix, Eb. Fischer \& Killmann & Parmotrema afrocetratum & Parmelinella afrocetrata \\
\hline 2007 & Parmotrema lacteum Marcelli \& Spielmann & Parmotrema lacteum & Parmotrema lacteum \\
\hline 2007 & Parmotrema pectinatum Jungbluth \& Marcelli & Parmotrema pectinatum & Parmotrema pectinatum \\
\hline
\end{tabular}

* - Names listed as nomen inquirendum are untypifiable because the type specimens are presumed lost, unavailable, or too fragmentary for study. See special part at page 498 .

Some years later, Hale (1974) reestablished the genus Parmotrema, including in it all the species previously included in his monograph (Hale 1965), as well as the species belonging to Vainio's (1890) Parmelia section Irregulares, which were not covered in Hale (1965). Initially, some lichenologists refused this classification (e.g., Krog \& Swinscow 1981), but later changed their approach (Krog \& Swinscow 1983; Swinscow \& Krog 1988). Currently, the name Parmotrema is widely accepted, although its exact delimitation is still controversial. About 350 species are known (Lücking et al. 2017; Spielmann, unpubl. data), of which 202 are recorded for Brazil (Aptroot, unpubl. data).

\section{Canomaculina Elix \& Hale and Rimeliella Kurok.}

Elix \& Hale (1987) proposed the genus Canomaculina for a group of species (the Parmelia pilosa group) that share (1) robust cilia, sharply spiky and usually furcated, (2) upper surface with effigurate maculae, and (3) filiform 
conidia $12-16 \mu \mathrm{m}$ long, recombining three species: Canomaculina consors, C. muelleri and C. pilosa. These had been previously studied by Hale $(1974,1976)$ inside the genus Parmelina Hale, at that time including species with lobes being adnate, narrow [(1) 2-4(-5) $\mathrm{mm}$ wide] and without usnic acid in the upper cortex.

A few years later, Kurokawa (1991) proposed the genus Rimeliella for seven species, then treated as Parmotrema, with wide lobes (5-15 $\mathrm{mm})$, and having as main characters (1) dimorphic rhizines, (2) undersurface brown to pale brown, (3) upper surface with effigurate maculae, and (4) usually little branched cilia.

Notwithstanding, Elix (1997) claimed that the only difference between Canomaculina and Rimeliella was the lobe width, and proposed the synonymization of Rimeliella under Canomaculina.

Presently, about 20 species that were at some time assigned to Canomaculina are known (Hale \& DePriest 1999) and 15 were already recorded for Brazil (Marcelli 2008).

\section{Rimelia Hale \& Fletcher}

The genus Rimelia was proposed by Hale \& Fletcher (1990) to accommodate a group of species (section Irregulares) that have (1) an upper cortex with reticulate maculae, (2) quite long (up to $2 \mathrm{~mm}$ ) not or little branched to squarrose rhizines that usually reach the lower margin of the lobes, (3) perforated apothecia, and (4) bacillar to filiform conidia 9-16 $\mu \mathrm{m}$ long. The most diagnostic character is, however, the presence of reticulate maculae, since there are some Parmotrema species with at least one of these features.

Based on molecular data, both Canomaculina and Rimelia were proposed as synonyms of Parmotrema (Blanco et al. 2005).

About 20 species of the former genus Rimelia are known today (Spielmann \& Marcelli 2006), 10 of them recorded from Brazil (Marcelli 2008). All are being treated as Parmotrema, as stated above.

\section{Species}

Acharius (1803) was the first to publish a species of parmotremoid lichen with salazinic acid, namely Parmelia perlata var. olivaria. This taxon was treated as Rimelia olivaria by Hale and Fletcher (1990). However, a proposal to reject it in favor of Parmotrema pseudoreticulatum (Hawksworth et al. 2003) was accepted (McNeill et al. 2006). Another species proposed by Acharius (1814) was Parmelia cetrata (Parmotrema cetratum), very frequently recorded in the lichenological literature and with an assumed worldwide distribution. Its morphological variation is quite expressive, and mainly for this reason, an extensive synonym list was accepted (Hale \& Fletcher 1990).

Lamarck \& De Candolle (1805) described Lichen perlatus $\alpha$ ciliatus, today a synonym of Parmotrema reticulatum (Hale \& Fletcher 1990).

Elias Fries, famous for his mycological contributions, also developed some studies with lichens. In his Systema
Orbis Vegetabilis (Fries 1825), he described Parmelia polita, today a synonym of Parmotrema cetratum (Hale $\&$ Fletcher 1990).

One year later, Persoon (in Gaudichaud-Beaupré 1826) proposed three species: Parmelia acanthifolia, P. badia and $P$. maura, all also placed as synonyms of Parmotrema cetratum by Hale \& Fletcher (1990).

Duby (1830) and Wallroth (1831) described, respectively, Parmelia perlata g ciliata and Parmelia perlata var. tentaculata. Both are considered synonyms of Parmotrema reticulatum (Hale and Fletcher 1990).

Then another widely distributed and very commonly recorded species was proposed: Parmelia reticulata (Mackay 1836). The main feature of this species, the reticulate pattern visible on the upper surface, was attributed to the maculae ['the surface marked with minute, whitish, elevated, reticulated lines' (Mackay 1836, p. 148)] and not to the lichen cracks, as sometimes mistaken by some lichenologists. This character, however, would be the cause of much confusion in the future, since the maculae are usually difficult to recognize and interpret (Brodo 1965). In other words, one would need to become familiarized with the maculae before recognizing them correctly.

In a consecutive publication, Taylor (1847) described P. cristifera and $P$. stuppea, both accepted today.

Apparently, the first illustration of parmotremoid lichen with salazinic was published by Fée (1837) when describing Parmelia latissima, a species still valid today. A few years later, Meyen and Flotow (1843) presented a beautiful illustration of Parmelia perforata var. replicata (now synonym of Parmotrema cetratum, according to Hale \& Fletcher 1990), based on specimens from Rio de Janeiro, Brazil. Another variety proposed in this paper, Parmelia perforata var. ulophylla, is a synonym of Parmotrema cristiferum (Hale 1965).

In 1866, Lindsay placed Parmelia reticulata Taylor as a variety of Parmelia laevigata, but this position was further rejected by his contemporaries (Hale $\&$ Fletcher 1990).

Krempelhuber $(1869,1873,1876 \mathrm{a} / \mathrm{b}, 1878,1881)$ published several new species and varieties. From these, Parmelia glaberrima var. flavescens, Parmelia subcaperata, and Parmelia uruguensis are accepted today. The name Parmelia glaberrima was rejected by Hale (1965), because it is a later homonym of Parmelia glaberrima (Fries 1825), a Lobaria species, according to that author. Parmelia angustata, $P$. perforata var. corniculata, and P. perforata f. integra are treated as synonyms of Parmotrema cetratum (Hale and Fletcher 1990). Parmelia hildebrandtii is a synonym of Parmotrema cristiferum (Hale 1965), while Parmelia concors belongs to of Parmotrema reticulatum (Hale \& Fletcher 1990).

Just one of the new species from Nylander (1869, $1878,1885,1886,1900)$, Parmelia subsumpta, is used today. His combination Parmelia flavescens was accepted at the species level as Parmotrema. Parmelia praeperlata is synonymous with Parmotrema reticulatum (Hale \& Fletcher 1990), while Parmelia imperforata belongs in Parmotrema subcaperatum (Hale 1965). 
Using his knowledge on conidia, Stirton (1877, 18771878), after discussing the differences between lichens from several parts of the world, proposed three species, two of them (Parmelia erubescens and P. reparata) are in current use. Parmelia owaniana is synonymous of Parmotrema cetratum (Hale \& Fletcher 1990).

Müller Argoviensis (1880, 1883, 1886, 1891a/b, 1892, 1894) was also prolific in the proposition of new names or new combinations. Nevertheless, only Parmelia cetrata var. subisidiosa (= Parmotrema subisidiosum) is still used today.

At the end of the 1800 s and early 1900 s, Vainio, the 'Father of Brazilian Lichenology' (Marcelli \& Ahti 1998), started his contributions involving Parmelia. His descriptions are clear and detailed, and his infrageneric classification scheme was outstanding, being the base of the classifications later developed (Feuerer 1998). Even so, from the species and varieties proposed (Vainio 1890, 1909a/b, 1918), just Parmelia delicatula persisted over time.

In 1896, Harmand described Parmelia perforata var. claudelii, and Vainio (1909a) accepted it as Parmelia claudelii. It is currently a synonym of Parmotrema stuppeum.

Detailed descriptions and remarks on the new species were published by Hue (1899), being Parmelia eurysaca, $P$. leucosemotheta and P. margaritata, names in use today (all as Parmotrema).

In his several contributions, Zahlbruckner (1902, $1904,1908,1909,1926,1928,1930 b)$ continued the tradition started by Vainio to present complete and accurate lichen descriptions. In addition, he is acknowledged for providing a complete list of known species of Parmelia (Zahlbruckner 1930a, 1934). Parmelia subtinctoria, $P$. ramescens, and P. ruminata (Magnusson \& Zahlbruckner 1944) are in current use.

Hale and Fletcher (1990) attributed to Jatta (1909) the publication of 'Parmelia perlata var. ciliata (Lam. \& DC.) Jatta'. However, in that paper, the name accepted by Jatta was 'Parmelia urceolata b. ciliata (DC.) Nyl.', that became a synonym of Parmotrema reticulatum.

Following the good examples of accurate descriptions presented by Vainio, Hue and Zahlbruckner, Lynge (1914, 1924), studying the Parmelia collected by Malme in South America, described Parmelia nylanderi and P. rupta, used today. Parmelia magna and $P$. radians are synonyms with Parmotrema delicatulum (Hale 1965). Parmelia hieronymi is synonymous of Parmotrema uruguense (Hale 1965 ) and Parmelia cetrata subsp. radiata is under Parmotrema cetratum (Hale \& Fletcher 1990).

While describing the lichens from Mexico collected by the Brother Arséne, Bouly de Lesdain (1914) proposed Parmelia moreliensis, currently in use.

Fink (in Fink \& Fuson 1919) published Parmelia ciliata, a superfluous combination, already done by Nylander (1878), and today listed as a synonym of Parmotrema reticulatum (Hale \& Fletcher 1990).

By this time, the application of the same names to species surely different was a quite common practice and very confusing in the literature. Du Rietz (1924a) contributed significantly to the clarification of the problems involving Parmelia perforata. However, his combination Parmelia trichothera var. claudelii (Du Rietz 1924b) is a synonym of Parmotrema stuppeum (Hale 1965).

Gyelnik (1931a, b, 1934) also contributed to the study of parmotremoid lichens. From the five names he proposed, none are currently in use. Parmelia amphygymnoides, Parmelia diffusoides and Parmelia pseudovirens are synonymous with Parmotrema reticulatum (Hale \& Fletcher 1990). Parmelia protovirens is listed under Parmotrema subtinctorium and Parmelia submesotropa under Parmotrema cristiferum (Hale 1965). Nevertheless, his understanding of the lichens and the nomenclatural aspects was quite ahead of his time (Hale 1990).

Cengia Sambo (1930, 1939a/b/c) worked with specimens from Brazil (Parmelia leucoxantha f. firma), Argentina and Ethiopia, proposing three infraspecific taxa, none of them in use today.

In his studies of the lichens of Taiwan (former Formosa), Asahina (1940) described Parmelia cetrata f. granularis. Later (Asahina 1952), he synonymized this taxon under Parmelia cetrata f. subisidiosa. Today, it is listed as a synonym of Parmotrema reticulatum (Hale \& Fletcher 1990).

Parmelia clavulifera, discovered by Räsänen (1944), was either believed to be a good species (Kurokawa 1991, Kurokawa \& Lai 2001, Moon et al. 2001) or a synonym of Parmotrema reticulatum (Hale \& Fletcher 1990, Divakar et al. 2005). The other propositions of Räsänen (1947), namely Parmelia perforata var. microspora and P. cinerascens var. saxicola, are synonyms of Parmotrema cetratum (Hale \& Fletcher 1990).

Magnusson (in Magnusson \& Zahlbruckner 1944) published one taxon in the group, Parmelia hawaiiensis, accepted today.

Another controversial species, recently studied using molecular tools (Divakar et al. 2005) is Parmelia pseudoreticulata (Tavares 1945).

Dodge (1959) published several new species or shifted to the species level many varieties of forms described by Hue and Müller Argoviensis. From his combinations, only Parmelia subisidiosa (today Parmotrema) is in current use.

Then we came to the contributions by Hale (1960, $1965,1971,1977$, and 1990). He studied many parmotremoid lichens, especially tropical species, doing a comprehensive revision of the existing names and proposing several new species, all in current use, but Parmelia microdactyla. The work of Hale is of fundamental importance since he could check the types, as well as a great amount of additional material, from all over the world. However, it seems that he used quite a broad species concept, accepting as synonyms many good taxa.

In those years, the chemical approach in lichenology was starting to use thin-layer chromatography (TLC). Using this technique and discussing in-depth the process of speciation in the lichenized fungi, Culberson (1973) and Culberson \& Culberson (1981) published Parmelia parahypotropa and Parmotrema paramoreliense, both accepted today. 
Very important contributions were also made by Kurokawa, with accurate descriptions and comments (Kurokawa 1974, 2001; Moon et al. 2001), maybe the main reason why all of his species are still in current use.

The combination of morphological and chemical features was always decisive in recognition of new species in Parmotrema. When lichexanthone was found for the first time in parmotremoid lichens, it justified the description of Parmelia ultralucens (Krog 1974), an isidiate species. Later, this substance was detected in three Brazilian species: the sorediate Parmotrema spinibarbe (Kurokawa 1984) and P. pontagrossense (Eliasaro \& Adler 1998), and P. lichexanthonicum (Eliasaro \& Adler 1997) without vegetative propagules.

At other times, an aberrant morphological feature can also raise the suspicion of a new taxon, as it occurred with Parmotrema arteagum, discovered in Mexico (Egan 1982). This species has very long conidia (16-23 $\mu \mathrm{m})$, very rare in Parmotrema.

Until the end of the 1970s, no species had been described by a Latin American lichenologist. Then, Ferraro (1979) published Parmotrema masonii, and Ferraro and Elix (1993, 2000) additionally discovered Rimelia cristobaliae and Canomaculina laciniella.
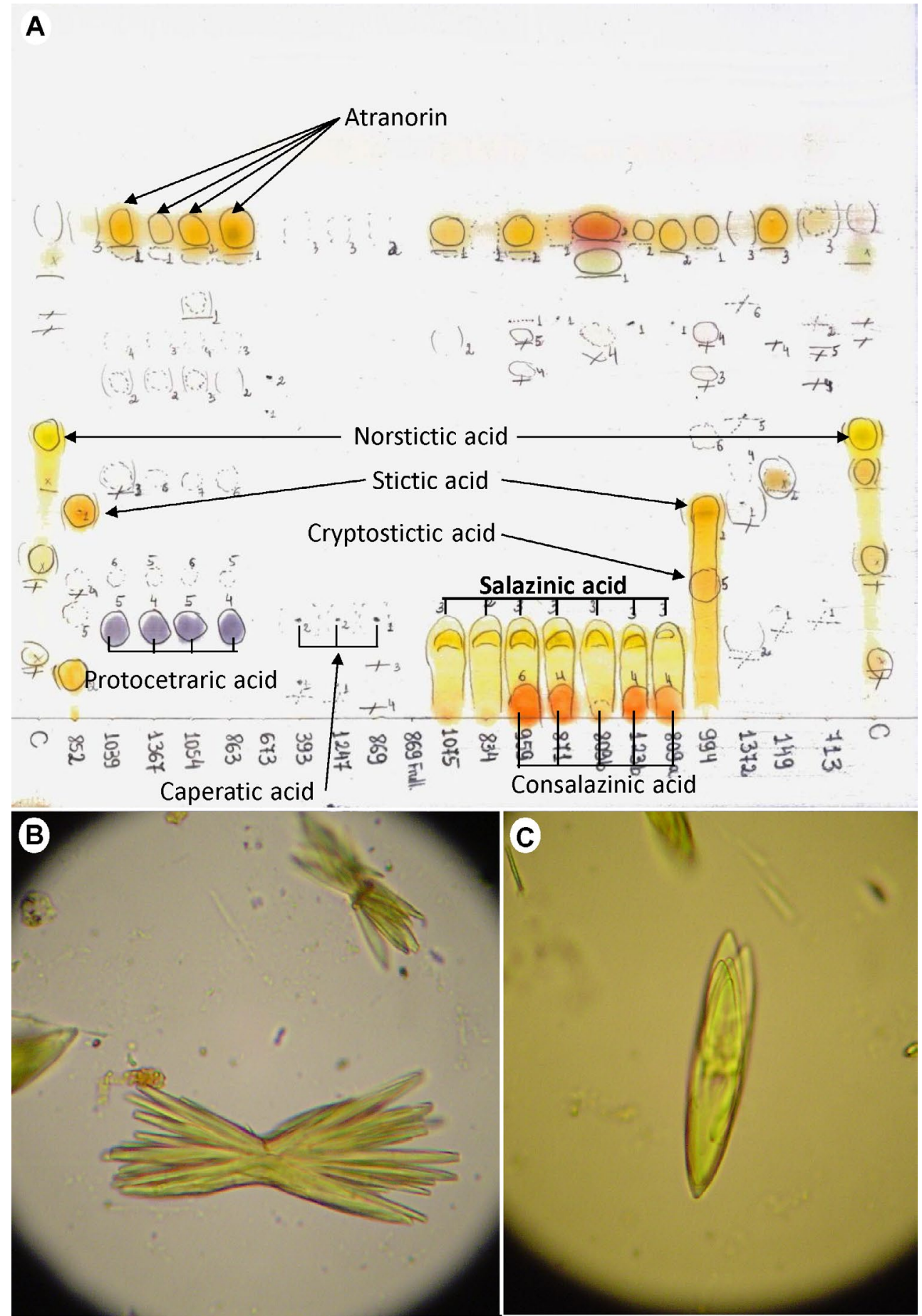

Figure 1. A - TLC plate showing several lichen substances in Solvent C; salazinic acid in bold (Photo L.S. Canêz); B and C - crystals of salazinic acid at the microscope $(100 \times)$. 
Adler (1988) did the first taxonomic doctoral thesis on Parmeliaceae in South America, where two species of parmotremoid lichens with salazinic acid were discovered: Canomaculina tandilensis and C. ventanica (Adler \& Elix 1987).

Several Australian and South American species were subjects of study by Elix and co-workers (Adler \& Elix 1987; Elix \& Johnston 1988; Ferraro \& Elix 1993, 2000; Elix et al. 2002, 2005; Benatti et al. 2008). In these papers, the chemical data provided are very valuable and carefully recorded.

Studying the lichens of the Guyana's and surrounding areas, Sipman and van Aubel (1992) published Parmotrema verrucisetosum, a unique species that presents ciliate verrucae in the upper surface. Sipman (2005) also deserves special acknowledgement for making available a relevant new version of a key to parmotremoid lichens in the Neotropics, originally made by Mason Hale.

In the 1990s, the Brazilian lichenologists started in-depth studies with parmotremoid lichens. Fleig (1997) made a revision of Parmotrema, Rimelia and Rimeliella of the Rio Grande do Sul, where a great set of material was studied, also including the types available.

Ribeiro (1998) worked with the Parmeliaceae from highlands of São Paulo, Rio de Janeiro and Minas Gerais. Inside the parmotremoid lichens, two new species were discovered: Parmotrema lobuliferum and P. neosubcrinitum (Marcelli \& Ribeiro 2002).
As one of the results of her doctoral thesis, Eliasaro (2001) also found two new species, both with lichexanthone (see above).

Several dissertations and theses worked with Brazilian Parmeliaceae, including parmotremoid lichens with salazinic acid (Canêz 2005; Spielmann 2005; Benatti 2005; Jungbluth 2006; Gerlach 2012; Cunha-Dias 2012; Buril 2015). These studies contained several new species, some already validly published: Parmotrema anchietanum, P. asperum, P. hypermaculatum (Benatti et al. 2008). Parmotrema fleigiae, P. lacteum and P. pectinatum (Marcelli et al. 2007), and Parmotrema marcellii (Gerlach \& Eliasaro 2014b).

Egan et al. (2016) presented a complete account of Parmotrema in Mexico, including several species with salazinic acid.

Recently, we had the opportunity to study the genus Parmotrema from the Galapagos Islands, Ecuador (Bungartz \& Spielmann 2019) and also discovered new species with salazinic acid: Parmotrema erectociliatum, P. marcellianum and $P$. saxoisidiatum.

\section{Salazinic acid}

Zopf, in 1897, named the acid he found in Stereocaulon salazinum as salazinic acid. Interestingly, the substance found by Zopf was not salazinic acid, rather it was norstictic acid (Asahina \& Shibata 1954; Lamb 1977). However,
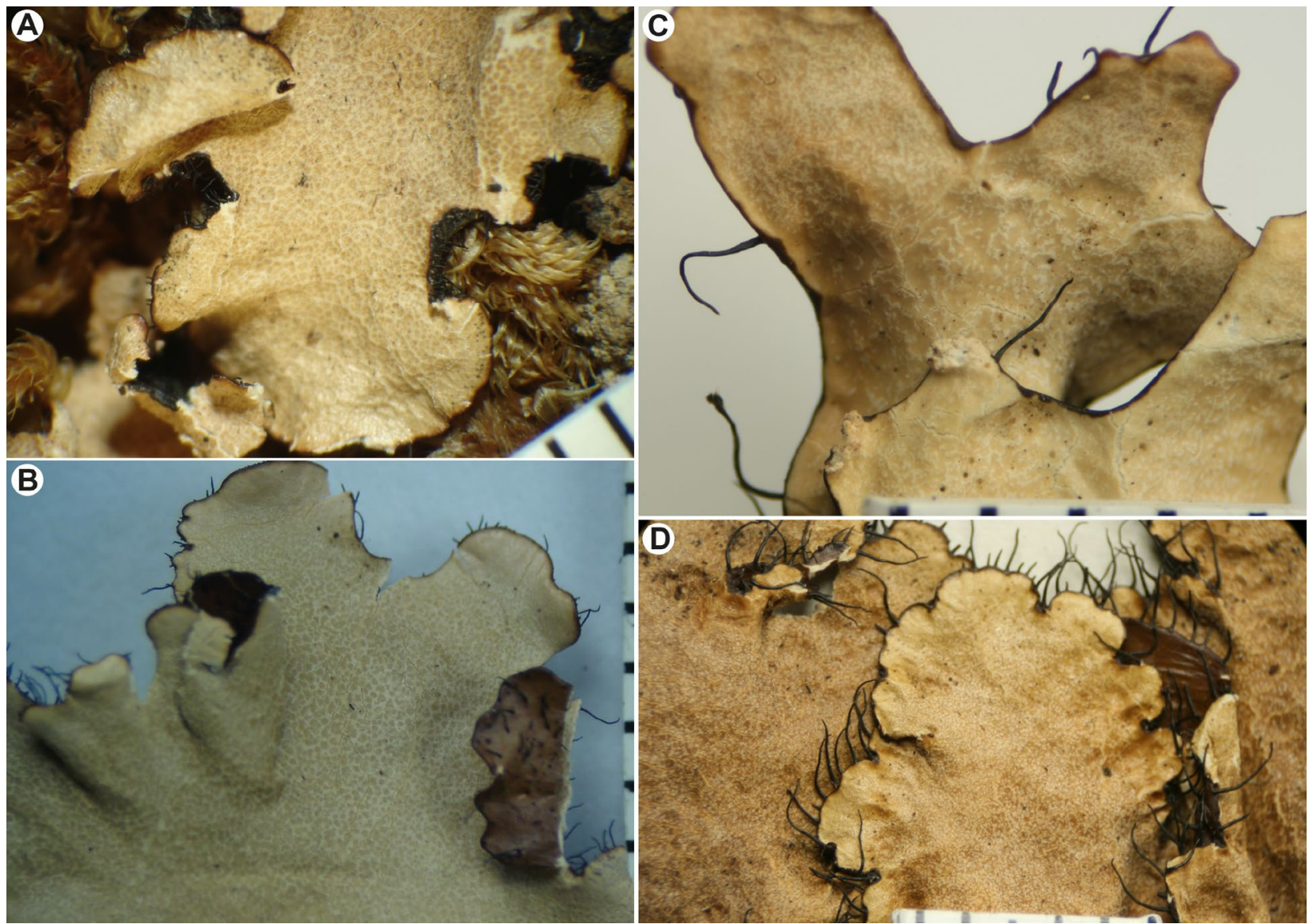

Figure 2. Reticulate maculae (A-B). A - isolectotype of Parmotrema reticulatum (BM); B - fresh specimen of Parmotrema reticulatum from Brazil. Effigurate maculae (C-D). C - holotype of Parmotrema paramoreliense (DUKE); D - Holotype of Parmotrema leucosemothetum (PC). Scales in milimeters. 

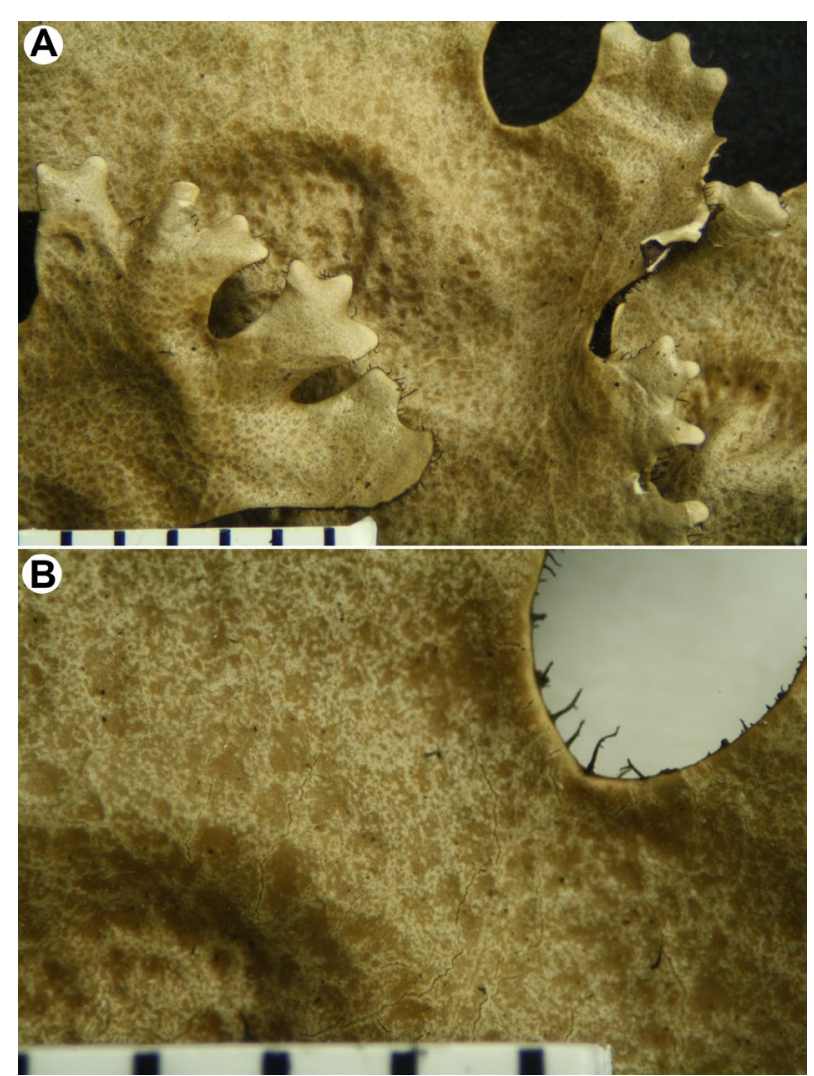

Figure 3. Pseudoreticulate maculae in the holotype of Parmotrema laciniellum (CTES). A - at low magnification; $\mathrm{B}$ - at high magnification. Scales in milimeters.

the name salazinic acid is not considered synonymous with norstictic acid but used for a different depsidone.

Asahina, in 1912, managed to isolate a large amount of salazinic acid from Parmelia cetrata [Parmotrema cetratum] (Asahina \& Shibata 1954). The recognition of this species as a source of salazinic acid was very important, because it is, together with Parmotrema reticulatum, frequently cited as a pattern for salazinic acid in chromatographic plates, as well as in lichen guides and manuals such as White and James (1985) and Orange et al. (2001).

Salazinic acid represents a depsidone and can be recognized in spot tests by the reaction $\mathrm{K}+$ yellow $\rightarrow$ blood red, C- and P+ deep yellow (Hale 1979; Orange et al. 2001 and our results). Under the microscope, the sections react $\mathrm{K}+$ deep yellow efflux forming very small, red crystals, different from the larger, needle-shaped crystals of norstictic acid. This also helps to distinguish the two substances in spot reactions, unless both are present (Lücking, pers. comm.). Although the recognition of color in spot tests is quite a variable feature, it seems that 'deep yellow' describes more appropriately the reaction of $\mathrm{P}$ with salazinic. It is different from the 'orange' color one obtains with $\mathrm{P}$ while studying specimens with protocetraric and or fumarprotocetraric acid.

In thin-layer chromatography, the salazinic acid has a Rf value 4 in solvent $C$ (Fig. 1A), 7 in solvent $B$, and 10 in solvent $\mathrm{A}$, forming orange spots on the plate (Orange et al. 2001). In microcrystallization using the reagent G.A.o-T., the salazinic acid forms small crystals described as 'masses of $\mathrm{Y}$ or $\mathrm{X}$ shape, the latter form bearing some resemblance to corn sheaves tied in the middle' (Lamb 1939; Fig. 1B) or as 'yellow boats' (Taylor 1967, Hale 1979; Fig. 1C).

\section{Material and methods}

Specimens were described using standard microscopic examinations. Anatomical sections of apothecia and pycnidia were hand-made with razor blades. Measurements were recorded from water mounts. Permanent slides were made for most types examined using resin PVLG $(8,33$ $\mathrm{g}$ of polyvinyl alcohol: $50 \mathrm{ml}$ of lactic acid: $50 \mathrm{ml}$ of distilled water: $5 \mathrm{ml}$ of glycerin) following Morton et al. (1993), adding cotton blue instead of Melzer's reagent, an adaptation introduced by Dr. Rosely A.P. Grandi (pers. comm.) to study anamorphic fungi in the Instituto de Botânica, SP, Brazil.

Spot tests were performed with potassium hydroxide $(\mathrm{K})$, sodium hypochlorite $(\mathrm{C})$, and para-phenylenediamine (P) for all specimens, except the oligotypes or when the chemical examination was not allowed by the herbarium curator. All taxa were also examined under UV light. Lichen substances were mainly identified by J.A. Elix (Canberra, Australia), from fragments of the types through TLC in solvent $\mathrm{C}$ and HPLC, following standard methods (Huneck \& Yoshimura 1996, Bungartz 2001, Orange et al. 2001). Published data based on the types studied were also included, if considered reliable.
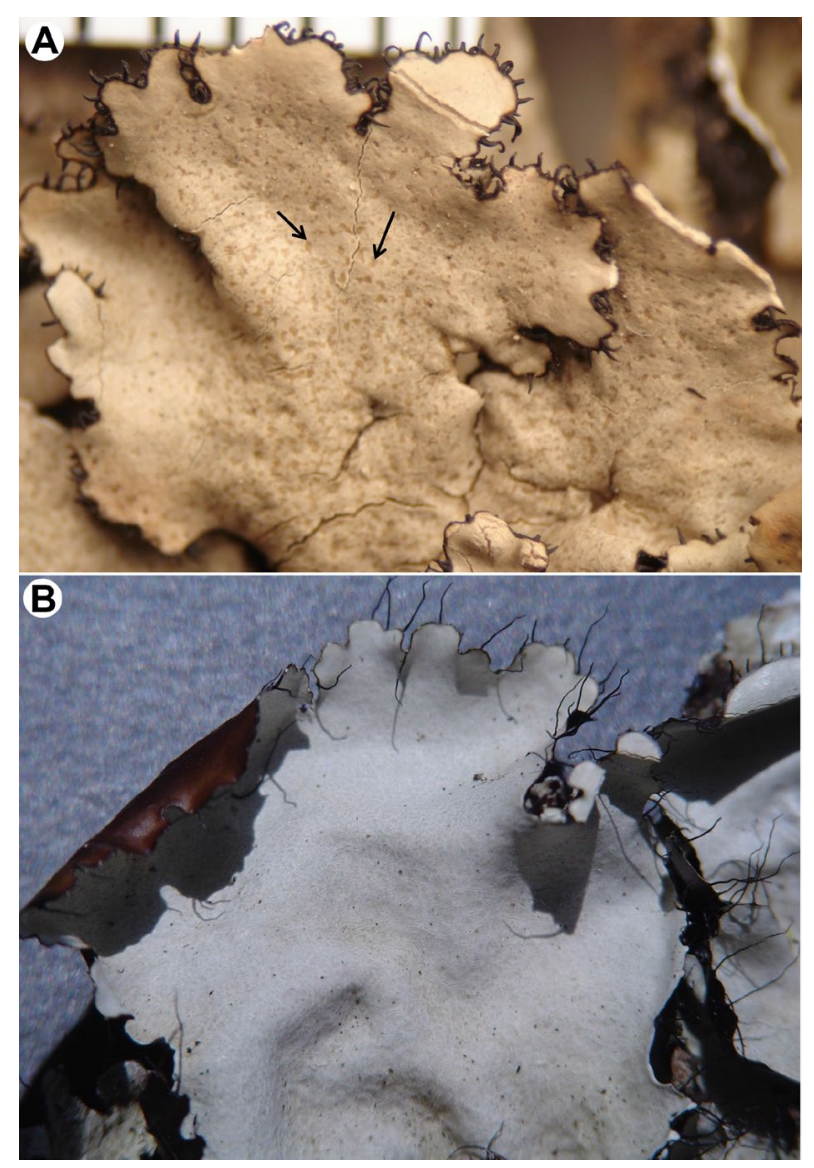

Figure 4. Hypermaculate thallus. A - holotype of Parmotrema ventanicum (BAFC), the arrows pointing to spaces without maculae; B Parmotrema austromaculatum (Spielmann 1342). Scales in milimeters. 


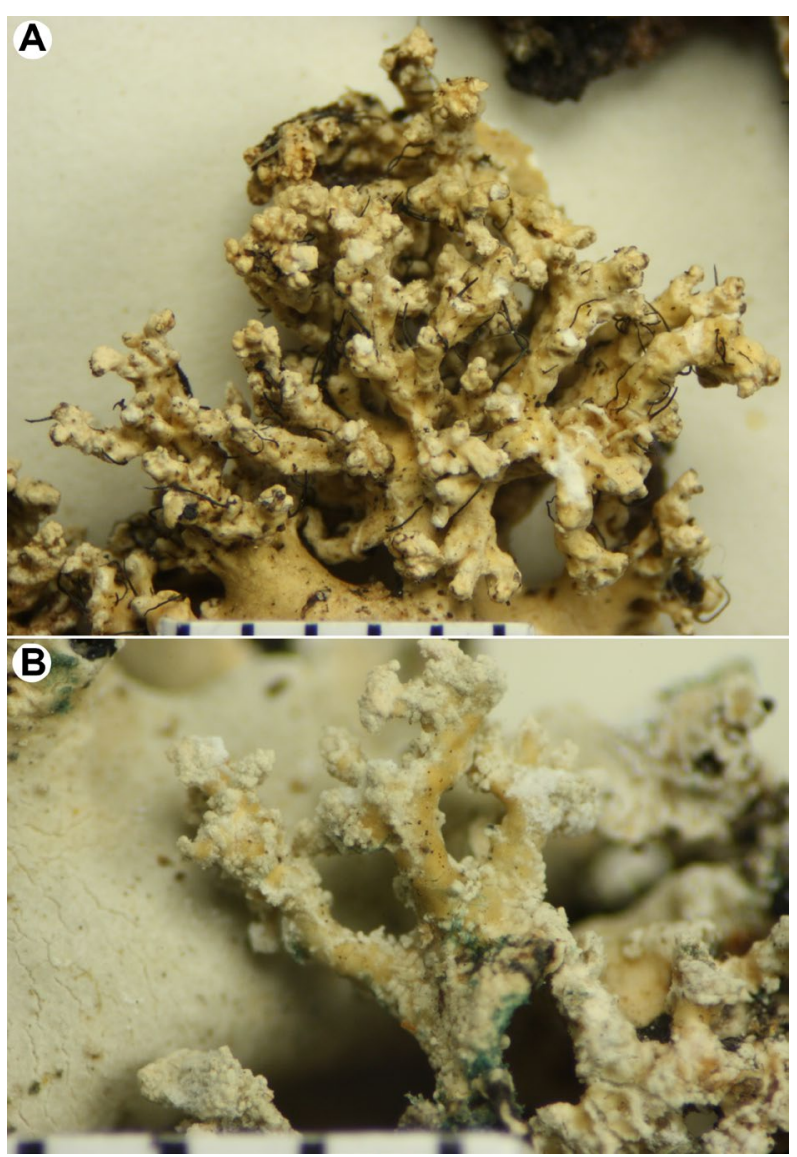

Figure 5. Arbusculae. A - ciliate arbusculae, holotype of Parmotrema coralliforme (US); B - sorediate arbusculae, holotype of Parmotrema ramusculum (BM). Scales in milimeters.

All specimens studied were also scanned at high resolution (1200 dpi). The resulting images were deposited in a data bank (http://parmotrema.myspecies.info/). Minute important features were also photographed coupling a digital camera (Canon EOS) with a stereomicroscope using a tripod.

The protocol used to describe the species (File S1) was an adaptation of that used by the GEL (Grupo de Estudos Liquenológicos) of the Instituto de Botânica (see Canêz \& Marcelli 2006, Marcelli et al. 2007). Besides the usually employed terms to define the maculation of the upper surface - reticulate (Fig. 2A-B) and effigurate (Fig. 2C-D) - two additional terms require explanation:

i) pseudoreticulate maculae (Fig. 3) - this pattern is formed by the confluence of abundant punctiform or effigurate maculae, resulting in a 'reticulate pattern' on the upper surface, when seen at low magnification or with the unaided eye. However, true originally reticulate maculae usually give origin to reticulate cracks, while in pseudo-reticulate species the cracks have usually an origin independent from the maculae. Example: Parmotrema laciniellum.

ii) hypermaculate (Fig. 4) - when the whitish macular regions are very abundant and cover most of the surface, i.e., the algae-free parts are by far more extensive than the green ones, rendering the thallus a distinctive milkish-grey or a very whitish color. Examples: Parmotrema austromaculatum, $P$. hypermaculatum and $P$. ventanicum.
A third term, iii) arbuscula (pl. arbusculae) (Fig. 5), was used for the structures named as 'coralloid isidia' by Hale (1965) since they are different from anything that could be called 'isidia' in other species. Arbusculae look like bushes or cauliflowers, with a thick, somewhat cylindrical basis and a much ramified upper portion. Examples: Parmotrema coralliforme and $P$. ramusculum.

The curators of the following herbaria kindly loaned specimens (acronyms follow Index Herbariorum): ASU, B, BAFC, BM, C, CANB, CHR, COLO, CTES, DUKE, F, FI, G, H, ICN, K, L, LD, M, MIN, MSC, O, P, RO, S, SP, TNS, TUR, UPS, UPCB, US, W, and WU. The herbarium FH did not send specimens, but made available the opportunity to study specimens at Farlow for two weeks. A twoweek stay was also performed in F, and four days in ICN.

\section{Results and discussion}

In the following account, 67 species of parmotremoid lichens with salazinic acid are described, commented on and illustrated. The revisionary work resulted in the recognition of three new species, 13 new combinations in Parmotrema, and one new combination in Parmelinella. Due to several aspects, 12 taxa remain in the Nomina inquirenda.

It was realized that the present species concept in the Parmotrema with salazinic acid is unsatisfactory since several well-defined species were 'hidden' under long lists of synonyms, usually accepted uncritically in numerous treatments. Even when trying to use a narrow species concept, some particular problems remain unsolved, like the present concept of Parmotrema cetratum and $P$. reticulatum. Since this study is primarily based on the types available, it cannot be considered a taxomic revision or an attempt to recognize species. Rather, the main idea was to provide the foundation for future phylogenetic revisions by providing detailed data on names and types.

\section{Worldwide key to the species of Parmotrema with salazinic acid}

Note: species marked with an asterisk $\left(^{*}\right)$ were not examined in detail here, and the protologues are indicated. The main key sections are indicated by subheaders to facilitate quicker access.

1 Thallus with vegetative propagules (isidia, arbusculae, soredia, isidioid soredia, pustules or schizidia) ... 2 Thallus without vegetative propagules ....... 50

2(1) Thallus with isidia or arbusculae (which may become

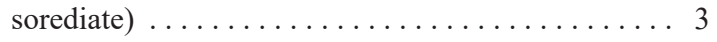
Thallus with soredia, isidioid soredia, pustules or schizidia ....................... 14

Thallus with isidia or arbusculae (which may become sorediate)

3(2) Thallus with typical isidia ............. 4

Thallus with arbusculae (Fig. 5) . . . . . . . 13

4(3) Cilia absent, medulla yellow ..... P. enteroxanthum Cilia present, medulla white (if cilia uncommon, see P. concurrens $) \ldots \ldots \ldots \ldots \ldots \ldots \ldots \ldots \ldots$ 
5(4) Upper cortex yellowish (usnic acid present) . . . . 6 Upper cortex greenish gray or grayish (atranorin as principal substance) ............... 7

6(5) Maculae conspicuous, effigurate, undersurface uniformly brown, rhizines dimorphic . . . . . . P. neotropicum

Maculae inconspicuous, apparently hypermaculate; undersurface black except for the marginal zone, rhizines monomorphic . . . . . . flavescens

7(5) Cespitose cilia common; medulla UV+ yellow (lichexanthone) .............. P.tralucens Cespitose cilia absent; medulla UV- (lichexanthone absent) $\ldots \ldots \ldots \ldots \ldots \ldots \ldots \ldots \ldots \ldots$

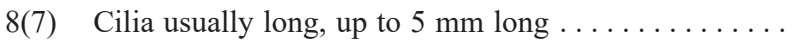
..... P. neosubcrinitum* (Marcelli \& Ribeiro 2002) Cilia usually shorter, up to $2 \mathrm{~mm}$ long .

9(8) Cilia sparse; maculae absent; medulla with gyrophoric and hypoconstictic acids (TLC) .....P. concurrens Cilia frequent to usually abundant; maculae evident, reticulate or effigurate; medulla without gyrophoric or hypoconstictic acids $\ldots \ldots \ldots \ldots \ldots \ldots \ldots$

10(9) Maculae reticulate; undersurface black ........ 11 Maculae effigurate, undersurface brown to dark brown ....................... 12

11(10) Isidia simple to coralloid, sparsely to abundantly ciliate; corticicolous ............. P. subisidiosum Isidia simple to sparsely branched, eciliate; saxicolous ....P. saxoisidiatum* (Bungartz \& Spielmann 2019)

12(10) Undersurface uniformly brown and veined; isidia ciliate present, sometimes breaking into soredioid granules; upper cortex yellowish (sometimes very difficult to observe), with usnic acid (minor); norlobaridone absent ................. Peotropicum Undersurface dark brown to black in the central zone, without veins (only slightly rugose to papillate); isidia not ciliate, remaining entire; upper cortex not yellowish (without usnic acid); norlobaridone present ........

P. subtinctorium

13(3) Arbusculae ciliate and esorediate; cilia abundant; undersurface dark brown; maculae effigurate. .......... $\ldots \ldots \ldots \ldots \ldots \ldots \ldots$ P. coralliforme Arbusculae eciliate and sorediate; cilia scarce; undersurface black; maculae punctiform..... . P. ramusculum

Thallus with soredia, isidioid soredia, pustules or schizidia

14(2) Upper cortex yellow or yellowish (dried specimens), K-; usnic acid present $\ldots \ldots \ldots \ldots \ldots \ldots \ldots . \ldots \ldots$ Upper cortex gray or brownish (dried specimens), $\mathrm{K}+$ yellow; usnic acid absent $\ldots \ldots \ldots \ldots \ldots 17$

15(14) Corticicolous; sorediate but not forming pustules; medulla C-, with hypoconstictic acid, without gyrophoric acid ........................ P. mirandum

Saxicolous; with soredia-producing pustules; medulla $\mathrm{C}+$ rose, with gyrophoric acid, without hypoconstictic acid $\ldots \ldots \ldots \ldots \ldots \ldots \ldots \ldots \ldots \ldots \ldots \ldots$

16(15) Thallus lobate, lobes $1-4.5 \mathrm{~mm}$ wide; cilia frequent to absent in some lobes

P. nylanderi
Thallus laciniate, laciniae $0.8-3 \mathrm{~mm}$ wide; abundantly ciliate

P. pectinatum

17(14) Thallus with abundant flaking off areolae (schizidia; Fig. 8B) .............. P. austrocetratum

Thallus with soredia, isidioid soredia or pustules (if pustules flaking off together with the areolae, see $P$. elixii and P. ruminatum) ............... 18

18(17) Thallus with isidioid soredia, formed by sorediose clusters ....................... lacteum

Thallus with soredia or pustules, not forming isidioid structures .................... 19

19(18) Thallus with pustules, which can produce soredia or not ......................... 20

Thallus without pustules, with soredia ....... . 29

20(19) Upper surface emaculate . . . . . . . . . . . . . . . P. fleigiae* (Marcelli et al. 2007) Upper surface hypermaculate or with maculae effigurate or reticulate $\ldots \ldots \ldots \ldots \ldots \ldots \ldots \ldots \ldots \ldots \ldots$

21(20) Upper surface hypermaculate (Fig. 4); cilia robust, tapering $\ldots \ldots \ldots \ldots \ldots \ldots \ldots \ldots \ldots \ldots \ldots$ ventanicum

Upper surface with maculae effigurate or reticulate (if also hypermaculate see $P$. marcellii); cilia simple or furcated, but not robust nor tapering $\ldots \ldots \ldots \ldots 22$

22(21) Maculae effigurate; lacinulae present; cilia frequently long (up to $3 \mathrm{~mm}$ ) and furcate (Fig. 40B) ........ ...................... petropoliense Maculae reticulate or upper surface becoming hypermaculate (see P. marcellii); lacinulae present or absent; cilia absent (see P. ruminatum) or if present, simple to squarrose (see $P$. granulare) or rarely furcate (see $P$. marcellii), usually shorter ............... 23

23(22) Cilia absent . . . . . . . . . . Puminatum

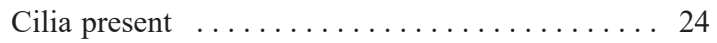

24(23) Pustules not forming soredia; lacinulae absent . . 25 Pustules forming soredia; lacinulae present or absent

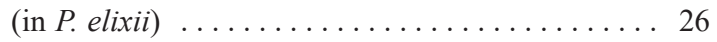

25(24) Maculae reticulate; conidia filiform, 9-12.5 $\mu \mathrm{m}$ long. . $\ldots \ldots \ldots \ldots \ldots \ldots \ldots \ldots$ P. nudum Maculae reticulate or upper surface becoming hypermaculate; conidia bacilliform, 3-6 $\mu \mathrm{m}$ long ....... ....... P. marcellii* (Gerlach \& Eliasaro 2014b)

26(24)Lacinulae absent $\ldots \ldots \ldots \ldots \ldots$. elixii Lacinulae present $\ldots \ldots \ldots \ldots \ldots \ldots \ldots 27$

27(26) Corticicolous; cilia simple to squarrose . P. granulare Saxicolous; cilia simple ............. 28

28(27) Lobes sublaciniate, usually $1-3 \mathrm{~mm}$ wide; lacinulae abundant ....P. anchietanum* (Benatti et al. 2008) Lobes subrotund, usually $2-6.5 \mathrm{~mm}$ wide; lacinulae sparse ......... P. asperum* (Benatti et al. 2008)

29(19) Cilia absent or rare; conidia sublageniform .... 30 Cilia present; conidia unciform (see P. parahypotropum), filiform or unknown $\ldots \ldots \ldots \ldots \ldots \ldots \ldots . \ldots 1$

30(29) Maculae absent; ascospores large $(24-35 \times 12-20 \mu \mathrm{m})$ $\ldots \ldots \ldots \ldots \ldots \ldots \ldots$. cristiferum 
Maculae punctiform to effigurate; ascospores medium-sized $(12-17 \times 6-9 \mu \mathrm{m})$ P. stuppeum

31(29) Lacinulae present (rare in P. concors) . . . . . . 32 Lacinulae absent ................. 40

$32(31)$ Maculae absent $\ldots \ldots \ldots \ldots \ldots \ldots \ldots \ldots \ldots$ Maculae present ..................... 34

33(32) Cilia simple, up to $1.2 \mathrm{~mm}$ long, thin, $0.02-0.05 \mathrm{~mm}$ wide ................. P. albinatum

Cilia simple to furcate or dichotomous, up to $2.5 \mathrm{~mm}$ long, usually thickened, $0.04-0.1 \mathrm{~mm}$ wide . . . . . . . ..................... maximum

34(32) Maculae reticulate (if reticulate to upper surface becoming hypermaculate see $P$. livido-tesselatum) .... . 35 Maculae effigurate (if effigurate to hypermaculate see P. margaritatum) ................. 38

35(34) Cilia simple to furcate, up to $3.5 \mathrm{~mm}$ long; maculae strong .............. P. lividotessellatum Cilia simple, rarely furcate, up to $1.5 \mathrm{~mm}$ long; maculae

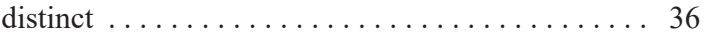

36(35) Soralia submarginal, usually labriform (rarely on lacinulae)

P. reticulatum

Soralia capitate, distinctly stalked, i.e., forming at the tips of distinctly elongated, lacinulate lobes (clavulae) . . . 37

37(36) Clavulae mostly blackened below, rarely with few, white

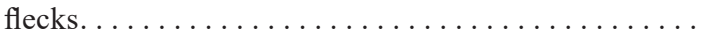
.. . P. marcellianum ${ }^{*}$ (Bungartz \& Spielmann 2019) Clavulae typically white below (cream color in herbarium) ............... clavuliferum

38(34) Soralia growing towards the undersurface; conidia unciform; medulla with norstictic and galbinic acids

P. parahypotropum

Soralia not growing towards the undersurface; conidia filiform or unknown; medulla without norstictic and galbinic acids ...................... 39

39(38) Lacinulae rare; cilia often stout and spiky, simple to furcate (Fig. 15A) . . . . . . . . . concors Lacinulae abundant (Fig. 33A); cilia simple.

P. margaritatum

40(31) Cilia mainly cespitose (Fig. 49B); medulla UV+ yellow (lichexanthone) $\ldots \ldots \ldots \ldots \ldots \ldots \ldots \ldots \ldots$ Cilia mainly simple; medulla UV- (without lichexanthone) .................... 42

41(40) Soredia produced in botryose structures (Fig. 49C) ... ...................... P. spinibarbe Soredia not produced in botryose structures $\ldots \ldots \ldots \ldots \ldots \ldots \ldots$. pontagrossense

42(40) Maculae absent $\ldots \ldots \ldots \ldots \ldots \ldots \ldots \ldots . \ldots 43$

Maculae present $\ldots \ldots \ldots \ldots \ldots \ldots \ldots \ldots 44$

43(42) Lobes narrow (2-6 mm wide); cilia erect (i.e., mostly turned upwards and thus perpendicular to the lobe edge), mostly simple ..................... .. . P. erectociliatum* (Bungartz \& Spielmann 2019) Lobes broad (8-25 mm wide); cilia horizontal, simple to furcated (Fig. 48C) . . . . . . . . . P. sieberi

44(42) Maculae reticulate (if reticulate to upper surface becoming hypermaculate, see P. foliolosum) . . . . . . . 45
Maculae effigurate (if punctiform to effigurate, see P. pseudoreticulatum) ............... 46

45(44) Cilia simple, up to $1.5 \mathrm{~mm}$ long; conidia 11-16 $\mu \mathrm{m}$ long ............... reterimulosum

Cilia simple to rarely furcated, shorter, up to $0.5 \mathrm{~mm}$ long; conidia 15-26 $\mu \mathrm{m}$ long ...... P. foliolosum

46(44) Thallus laciniate; cilia long (up to $5 \mathrm{~mm}$ long) ...... .................... paramoreliense Thallus lobate; cilia shorter (up to $3 \mathrm{~mm}$ long) . . 47

47(46) Undersurface black; cilia short, up to $0.5 \mathrm{~mm}$ long . . . .................. pseudoreticulatum

Undersurface light to dark brown, rarely blackish-brown in central areas; cilia longer, up to $3 \mathrm{~mm}$ long ... 48

48(47) Rhizines monomorphic ....... P. leucosemothetum Rhizines dimorphic .................. 49

49(48) Soralia growing towards the undersurface ........ .................... P. subsumptum

Soralia growing towards the upper surface ... P. reitzii

Thallus without vegetative propagules

50(1) Upper cortex yellowish or grayish yellow (usnic acid with or without atranorin) $\ldots \ldots \ldots \ldots \ldots \ldots . \ldots 5$

Upper cortex greenish gray or grayish (atranorin as dominant substance; if usnic acid also present, see $P$. subcaperatum; if traces of usnic acid, see P. laciniellum) . . . . 54

51(50) Upper surface with effigurate maculae; rhizines dimorphic ................. subcaperatum Upper surface without maculae; rhizines monomorphic ........................ 52

52(51) Cilia up to $0.7 \mathrm{~mm}$ long; medulla $\mathrm{C}-$, without gyrophoric acid . . . . . . . . . . . . . . . . . . P. masonii

Cilia up to $2.8 \mathrm{~mm}$ long; medulla $\mathrm{C}+$ rose or $\mathrm{C}-$, gyrophoric acid present in variable concentration .... 53

53(52) Thallus lobate, lobes broad (5-15 mm wide); apothecial disc usually lacerate, amphithecium rugose to scrobiculate ....................... P. magnum

Thallus sublaciniate, sublaciniae narrow (1-3.5 mm wide); apothecial disc entire, amphithecium smooth . . .................... delicatulum

54(50) Thallus totally laciniate (Figs. 24, 55B), laciniae narrow (up to $3 \mathrm{~mm}$ ) .................... 55

Thallus lobate or wide-laciniate $(2-5 \mathrm{~mm}$ or even

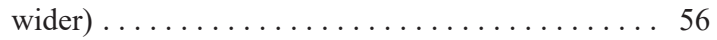

55(54) Cilia simple . . . . . . . . . . . P. warmingii Cilia usually branched (Fig. 24B) . . . . . P. herrei

56(54) Upper surface with ciliate warts (Fig. 55A) . . . . . . . $\ldots \ldots \ldots \ldots \ldots \ldots \ldots$. verrucisetosum Upper surface without ciliate warts $\ldots \ldots \ldots 57$

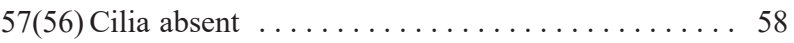

Cilia present $\ldots \ldots \ldots \ldots \ldots \ldots \ldots \ldots . \ldots . \ldots 59$

58(57) Lobes broad, 6-25 mm wide; maculae absent; conidia sublageniform ............ latissimum

Lobes narrow, 1-5 mm wide; maculae effigurate; conidia filiform

P. acutatum 
59(57) Cilia mainly cespitose; medulla UV+ yellow (lichexanthone) ............... P. lichexanthonicum Cilia simple or furcated; medulla UV- (without lichexanthone $\ldots \ldots \ldots \ldots \ldots \ldots \ldots \ldots \ldots \ldots$

60(59) Lobes markedly convolute (Fig. 14A). . P. clercianum Lobes plane . . ............... 61

61(60) Thallus foliose to subfruticose; conidia 16-23 $\mu \mathrm{m}$ long ............ P. arteagum* (Egan 1982) Thallus distinctly foliose; conidia shorter, up to $19 \mu \mathrm{m}$

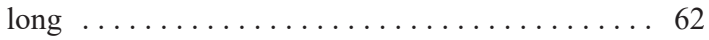

62(59) Thallus with abundant marginal lobules .......... ....... P. lobuliferum* (Marcelli \& Ribeiro 2002) Thallus usually without marginal lobules (if adventitious lobules present see P. ruptum) .......... 63

63(60) Maculae absent ........... P. mantiqueirense Maculae present .................... 64

64(63) Undersurface pale brown to brown blackish; maculae primarily effigurate; lacinulae absent ....... 65

Undersurface black; maculae effigurate, reticulate or hypermaculate; lacinulae present or absent .... 68

65(64) Cilia usually furcated (Fig. 10B); maculae strong (Fig. 10C) . . . . . . . . . . . . . . . . . . 66 Cilia rarely furcated; maculae weak to distinct . . 67

66(65) Cilia thick; rhizines monomorphic ...... P. bifidum Cilia thin; rhizines dimorphic P. uruguense $^{*}$ (Hale 1965)

67(65) Undersurface extensively light brown; usnic acid

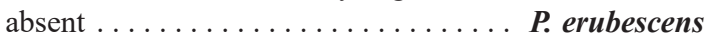
Undersurface brown to blackish-brown; usnic acid present $\ldots \ldots \ldots \ldots \ldots \ldots \ldots \ldots$ P. subcaperatum

68(64) Maculae primarily effigurate (sometimes upper surface becoming hypermaculate) . . . . . . . . . . 69 Maculae primarily reticulate or upper surface becoming hypermaculate, never effigurate $\ldots \ldots \ldots \ldots 75$

69(68) Rhizines dimorphic . . . . . . . . . . . . . 70 Rhizines monomorphic ............. 71

70(69) Lacinulae present; medulla with norlobaridone ..... ..................... Pristobaliae Lacinulae absent; medulla without norlobaridone .... ....................... reparatum

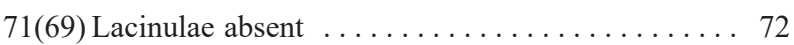
Lacinulae present (if sublacinulate see $P$. despectum) $\ldots \ldots \ldots \ldots \ldots \ldots \ldots \ldots \ldots \ldots \ldots$

72(71) Cilia simple ............ P. permaculatum Cilia mostly furcate (Fig. 21B) ...... P. expansum

73(71) Cilia short, up to $0.5 \mathrm{~mm}$ long ...... P. laciniellum Cilia longer, up to $2.2 \mathrm{~mm}$ long ... . . . . . . . 74

74(73) Thallus distinctly lacinulate; cilia abundant, robust and tapering ......P. tandilense $^{*}$ (Adler \& Elix 1987) Thallus only with sublacinulae; cilia frequent, simple, not tapering . .............. despectum

75(67) Lacinulae present (if sublacinulate see P. ruptum) . 76 Lacinulae absent 80
76(75) Maculae reticulate, distinct but never strong P. cetratum

Maculae reticulate to upper surface becoming hypermaculate, strong, $\ldots \ldots \ldots \ldots \ldots \ldots \ldots \ldots \ldots \ldots \ldots$

77(76) Apothecia perforate . . . . . . . . . . . . 78

Apothecia imperforate . . . . . . . . . . . . . 79

78(77) Lacinulae with acute apices, ornate with black outlined pycnidia ................ P. eurysacum

Lacinulae often spatulate or with the apex enlarged, pycnidia without black outline... P. austromaculatum

79(77) Cilia short, up to $0.5 \mathrm{~mm}$ long ........ P. ruptum

Cilia longer, up to $2.6 \mathrm{~mm}$ long . . . . . . . . . ....... P. hypermaculatum* (Benatti et al. 2008)

80(75) Cilia usually simple, up to $1 \mathrm{~mm}$ long; conidia $6.5-9 \mu \mathrm{m}$ long................... acanthifolium

Cilia usually squarrose, up to $2 \mathrm{~mm}$ long; conidia $10-15$ $\mu \mathrm{m}$ long $\ldots \ldots \ldots \ldots \ldots \ldots \ldots$ P. radiatum

\section{Taxonomy}

Parmotrema acanthifolium (Pers.) Spielmann \& Marcelli, comb. nov.

(Fig. 6A)

\section{MycoBank MB 838183}

Basionym: Parmelia acanthifolia Pers., in Gaudichaud-Beaupré, Voyage autour du monde, exécuté sur les corvettes l'Uranie et la Physcienne, sur les ordres du Cap. L. de Freycinet, en 1817-1820, Botanique, p. 197. 1826.

Type: Brazil. Rio de Janeiro: corticicolous, Gaudichaud 13 (holotype - PC!)

Description (based on holotype). Thallus brownish (herbarium), lobate, corticicolous, $9 \mathrm{~cm}$ broad. Lobes irregularly branched, laterally overlapped, 2-7 mm wide, surface continuous, smooth, lustrous, becoming irregularly cracked towards the center; apical zone rounded; margin crenate to sinuous, slightly undulated. Maculae reticulate to extensive (hypermaculate), sometimes inconspicuous, laminal, not originating cracks. Cilia black, simple or rarely with lateral branchlets, up to $1 \mathrm{~mm}$ long, 0.02-0.06 mm wide, abundant. Lacinulae, pustules, soredia and isidia absent. Medulla white. Undersurface impossible to describe in detail since the thallus is totally glued to a paper sheet, apparently black, lustrous, smooth to rugose or papillate; marginal zone brown, lustrous, 1-2 mm wide, rhizinate to papillate, with an attenuated limit; rhizines black, simple to squarrose, up to $2 \mathrm{~mm}$ long, 0.01-0.05 mm wide, apparently abundant.

Apothecia cupuliform, 2-10 $\mathrm{mm}$ in diameter, stipitate, submarginal, margin crenate to sinuous, amphithecium maculate, smooth or irregularly pitted, disc dark brown, epruinose, perforate at maturity; ascospores ellipsoid, 13.5-15 × 8.5-10 $\mu \mathrm{m}$, episporium ca $1 \mu \mathrm{m}$. Pycnidia submarginal, conspicuous, with or without prominent margin, abundant, ostiole black; conidia short-filiform, 6.5-9 $\times \sim 1 \mu \mathrm{m}$.

Chemistry. Atranorin (minor), chloroatranorin (trace), salazinic acid (major) and consalazinic acid (minor). 
Cortex $\mathrm{K}+$ yellow, UV-; medulla $\mathrm{K}+$ yellow $\rightarrow$ blood red, $\mathrm{C}-, \mathrm{KC}-, \mathrm{P}+$ strong yellow, $\mathrm{UV}-$.

Remarks. Parmotrema acanthifolium is distinct by the lobate thallus with reticulate maculae or hypermaculate, the short conidia $(6.5-9 \mu \mathrm{m})$ and the absence of lacinulae. This species is close to P. cetratum, and was already considered a synonym (Hale \& Fletcher 1990). However, the hypermaculate thallus and shorter conidia (10-14 $\mu \mathrm{m}$ in $P$. cetratum according to Hale \& Fletcher 1990) seem to be sound characters to recognize $P$. acanthifolium as a separate species. Parmotrema ruptum, another close species, has imperforate apothecia, longer conidia (10$12.5 \mu \mathrm{m})$, shorter ascospores $(10-12.5 \times 6-7.5)$ and a distinct bare marginal zone on the undersurface. Apparently, one of the first authors to accept Parmelia acanthifolia as a good taxon was Vainio (1890), applying this name to specimens gathered by him in Sítio (nowadays Municipality of Antonio Carlos, Minas Gerais, Brazil). Afterwards, Müller Argoviensis (1893) reported the species to Costa Rica, Hue (1895) to California (USA), Zahlbruckner (1909) included it in his key to the Brazilian Parmelia,
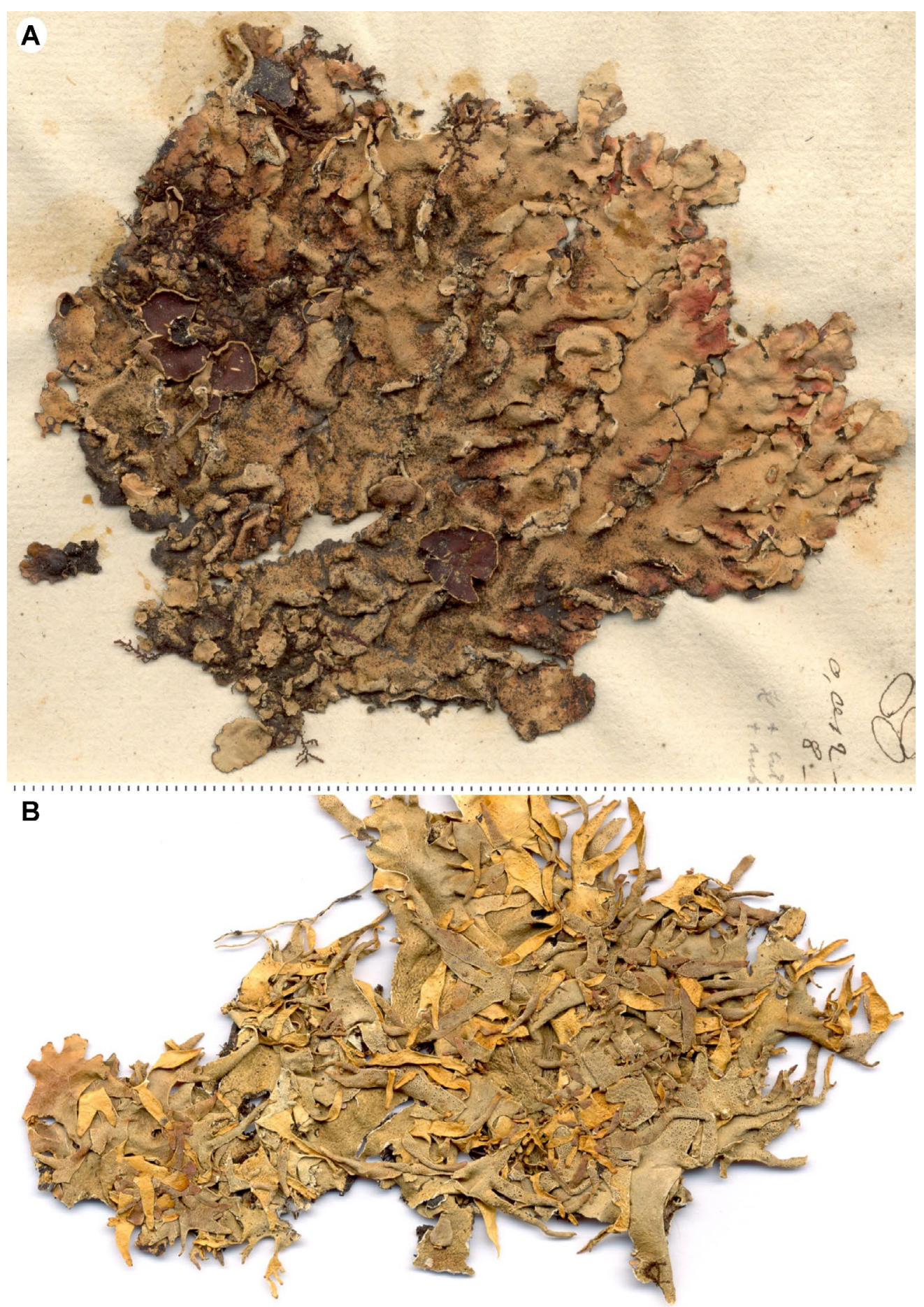

111IIIIIIIIIIIIIIIIIIIIIIIIIIIIIIIIIIIIIIIIIIIIIIIIIIIIIIIIIIIIIIIIIIIIIIIIIIIIIIIIIIIIIIIIIII

Figure 6. A - lectotype of Parmotrema acanthifolium (PC); B - holotype of Parmotrema acutatum (US). Scales in milimeters. 
and Lynge (1924) mentioned it for Uruguay. Hale (1960) questioned the record of Vainio (1890), stating that it was based on Parmelia subcaperata, but he was unable to review the report from Lynge (1924), because that specimen was probably destroyed in Berlin during the Second World War.

In the protologue (Gaudichaud-Beaupré 1826), only one specimen was cited, and so it is the holotype (Shenzhen Code, article 9.1 Note 1), not a lectotype as suggested by Hale \& Fletcher (1990).

Distribution. USA (Hue 1895), Costa Rica (Müller Argoviensis 1893), Brazil (Vainio 1890) and Uruguay (Lynge 1924). In Brazil, it was recorded from Minas Gerais (Vainio 1890) and Rio de Janeiro (Gaudichaud-Beaupré 1826).

Parmotrema acutatum Kurok., Bulletin of the National Science Museum Tokyo, Ser. B, 27(1): 3. 2001.

Type: Mexico. Nayarit: near Tepic, Rt. 15, Km. 865, on tree, July 1961, M. Wirth 26 (holotype - US!; isotypes - TNS, US!).

Description (based on holotype). Thallus pale brownish (herbarium), lobate (but abundantly lacinulate), loosely adnate, corticicolous, $9.5 \mathrm{~cm}$ broad. Lobes irregularly branched, somewhat crowded, 1-5 mm wide, surface continuous to irregularly cracked, smooth, sublustrous to opaque, becoming rugose and reticulately cracked in the older parts; apical zone subtruncate; margin smooth to sublacinulate, undulated. Maculae distinct, effigurate or rarely pseudoreticulate in some lacinulae, laminal, originating cracks. Cilia absent (but see the Comments below). Lacinulae simple, furcated or usually with lateral branches, present in the whole thallus, plane to slightly canaliculated, apex acute, up to $1.5 \mathrm{~mm}$ long, $0.5-3 \mathrm{~mm}$, undersurface beige. Pustules, soredia and isidia absent. Medulla white. Undersurface black, sublustrous to lustrous, smooth to rugulose or papillate, rarely veined, with numerous cracks; marginal zone beige, opaque to sublustrous, 2-6 mm wide, naked, with sharp limit, smooth, slightly to strongly rugose or rarely with subtle veins; rhizines black, simple to less frequently branched, up to $1.5 \mathrm{~mm}$ long, $0.05-0.1 \mathrm{~mm}$ wide, frequent, irregularly distributed.

Apothecia absent. Pycnidia submarginal to laminal, almost exclusively on the lacinulae, conspicuous, usually with prominent margin, frequent, ostioles black; conidia filiform, $10-19 \times \sim 1 \mu \mathrm{m}$.

Chemistry. Atranorin (minor), chloroatranorin (trace), salazinic acid (major), consalazinic acid (minor). Cortex $\mathrm{K}+$ yellow, $\mathrm{UV}-$; medulla $\mathrm{K}+$ yellow $\rightarrow$ blood red, $\mathrm{C}-$, $\mathrm{KC}-, \mathrm{P}+$ strong yellow, $\mathrm{UV}-$.

Remarks. Parmotrema acutatum is recognized by the effigurate maculae (sometimes pseudoreticulate), abundant lacinulae, black undersurface (beige under the lacinulae) and the absence of cilia. Parmotrema eurysacum also develops abundant lacinulae, but can be easily distinguished by the presence of long cilia (up to $3.5 \mathrm{~mm}$ ) and the hypermaculate upper surface.
Additionally, the lacinulae are curiously ornate with black outlined pycnidia and their undersurface is black, the conidia are short-filiform, 6-9 $\mu \mathrm{m}$ long, and the medulla also produces gyrophoric acid. Another species with long lacinulae is P. laciniellum, which in turn also has effigurate maculae, but develops abundant, short cilia (up to $0.5 \mathrm{~mm}$ ).

When describing P. acutatum, Kurokawa (2001) illustrated one specimen that is labeled in US as isotype. Actually, the sheet has two thalli, one of them with wider lobes $(3-10 \mathrm{~mm})$ and relatively less lacinulate that the other specimen and the holotype. These two specimens, nevertheless, agree in the general features with the holotype.

Parmotrema acutatum was originally described as an eciliate species (Kurokawa 2001), and we agree with Kurokawa in this point. However, rare structures are present in both the margin and upper surface of two lacinulae in the holotype, and in three lobes and lacinulae in the isotype. All but one of these structures can be soundly considered adventitious rhizines, yet additional specimens can prove if this is really an eciliate species.

Distribution. Mexico (Kurokawa 2001; Egan et al. 2016).

Parmotrema albinatum (Moon, Kurok. \& Kashiw.) Blanco, Crespo, Divakar, Elix \& Lumbsch, Mycologia 97(1): 157. 2005.

(Fig. 7)

Basionym: Rimelia albinata K.H. Moon, Kurok. \& Kashiw., Journal of Japanese Botany 76(6): 322. 2001.

Type: USA Hawaii: Molokai Island, Molokai District, below Puu Kolekole, $21^{\circ} 05^{\prime} \mathrm{N}, 156^{\circ} 54^{\prime} \mathrm{W}$, about $1150 \mathrm{~m}$ alt., on soil, November 4, 1997, Y. Ohmura 4210 (holotype - TNS!; isotype - BISH).

Description (based on holotype). Thallus whitish, sublaciniate, loosely adnate, terricolous, $6.5-10 \mathrm{~cm}$ broad; sublaciniae irregularly branched, crowded, $2-5 \mathrm{~mm}$ wide; surface continuous to minutely notched, rarely cracked, smooth to irregular, lustrous, pruinose in the lobes apices; apical zone rounded; margin crenate to sublacinulate, undulated. Lacinulae simple to furcated, localized in the whole thallus, usually plane, sometimes slightly canaliculated, apex acute when without soredia, although frequently sorediate, then capitate or growing backwards, $0.5-2.5 \times 0.3-1.5 \mathrm{~mm}$, underside beige. Maculae absent (see Remarks below). Cilia black, simple, thin, $0.5-1.2 \times$ $0.02-0.05 \mathrm{~mm}, \pm$ abundant. Soralia concolor to the thallus, capitate, extensive or labriform, formed on the lacinulae apices or in some margins, which become involute; soredia subgranular. Isidia and pustules absent. Medulla white. Undersurface black (beige under the lacinulae and sorediate lobes), lustrous, papillate, rarely with scars; marginal zone dark brown, lustrous, $1.5-2 \mathrm{~mm}$ wide, rhizinate or sometimes without rhizines, with an attenuated limit, smooth to papillate; rhizines black, simple, branched near the apices or squarrose, $0.5-2 \times 0.01-0.06 \mathrm{~mm}$, abundant, \pm evenly distributed.

Apothecia absent. Pycnidia laminal to submarginal, especially abundant in the lacinulae, conspicuous, frequent, ostiole black; conidia filiform, 7.5-10 $\times \sim 1 \mu \mathrm{m}$. 
Chemistry. Atranorin, salazinic and trace of lobaric acid (Moon et al. 2001). Cortex K+ yellow, UV-; medulla K+ yellow $\rightarrow$ blood red, $\mathrm{C}-$, $\mathrm{KC}-$, $\mathrm{P}+$ strong yellow, $\mathrm{UV}-$.

Remarks. Parmotrema albinatum is characterized by the sorediate and short-lacinulate thallus with medullar salazinic acid and traces of lobaric acid. The upper surface is distinctly whitish, probably caused by the very thick upper cortex. It is close to $P$. clavuliferum, a species producing long lacinulae and which instead of lobaric acid produces only fatty acids (Kurokawa 1979).

The maculae are absent in this species. Nevertheless, the upper cortex is as white as the maculae normally are in Rimelia-like species, and what one can see in P. albinatum is just an inconspicuous surface relief in a reticulate pattern.

The specimen preserved in TNS is labeled as the holotype, and one of its parts was illustrated in the protologue, so probably the isotype is in BISH. This information is contrary to that published in the same protologue (Moon et al. 2001). There is no statement if the three parts in the holotype collection are from the same thallus, and only one of them was illustrated in the protologue. They are, notwithstanding, similar in every respect and seem to really be parts of the same specimen. A label with the holotype, made by K.H. Moon in 1998, gives the following chemistry: atranorin, norlobaridone and salazinic acid. One other label (undated, but with Kurokawa's handwriting), asserts that the specimen Ohmura 4210 has atranorin, salazinic acid and lobaric acid $(++)$. The last information is taken, at the moment, as correct since it was published in the protologue.

The terricolous habit of the holotype (Fig. 7B) is very rare in this group of species (apparently just known in $P$. herrei). However, in the protologue one saxicolous and one corticicolous specimen are additionally listed. So maybe the substrate, in this case, is not an important feature to be considered.

Distribution. Hawaiian Islands (Moon et al. 2001).
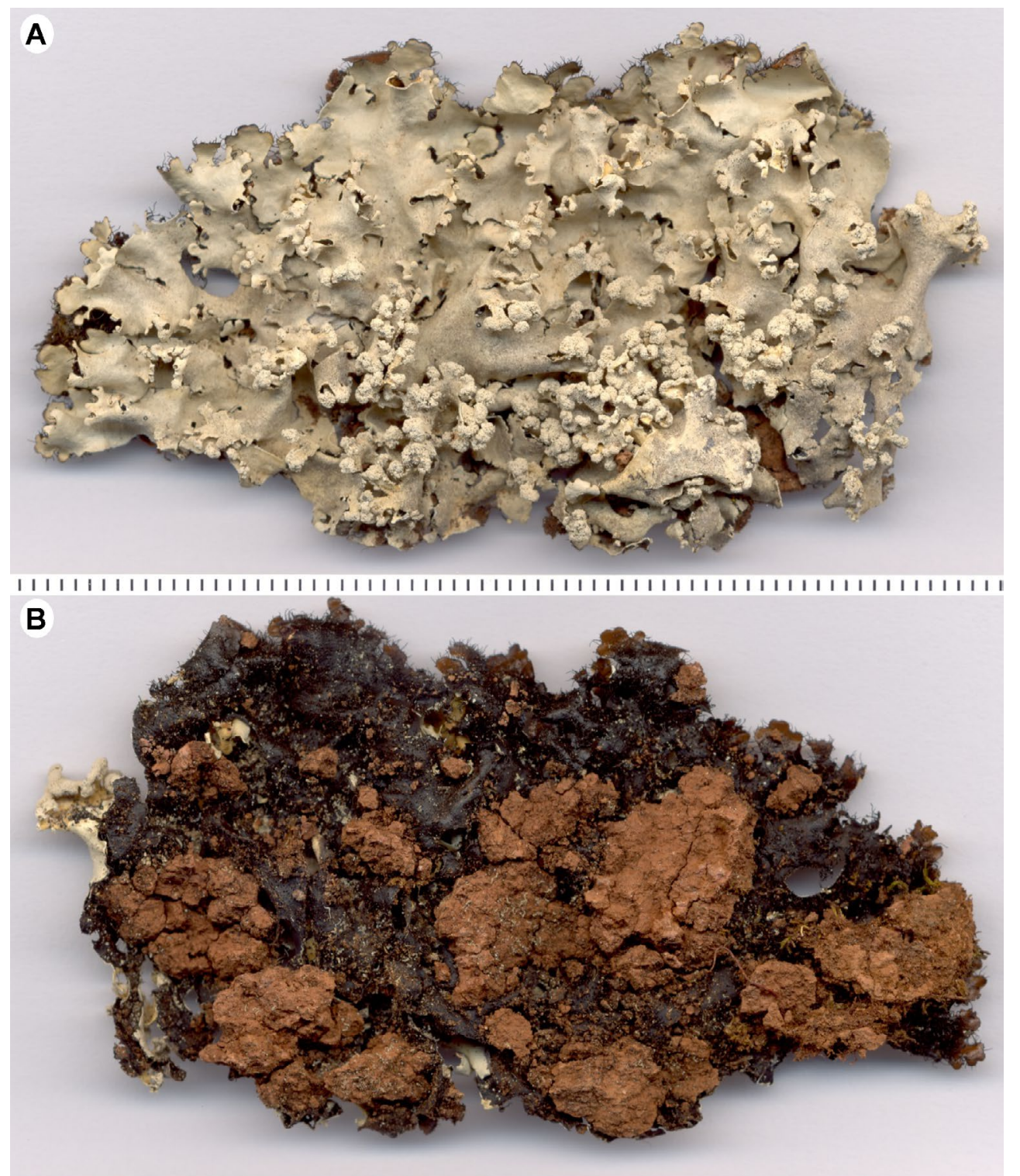

Figure 7. Holotype of Parmotrema albinatum (TNS). A - upper surface; B - undersurface. Scales in milimeters. 
Parmotrema austrocetratum Elix \& Johnston, Mycotaxon 31(2): 495.1988

(Fig. 8)

Type: New Zealand. North Island: Taranaki Land District, New Plymouth, Burgess Park, $60 \mathrm{~m}$, on tree trunk in remnant forest, 07.V.1980, J.A. Elix 7979 (holotype - CHR!; isotype - CANB!).

$\equiv$ Rimelia austrocetrata (Elix \& Johnston) Hale \& Fletcher, The Bryologist 93(1): 26. 1990.

Description (based on holotype). Thallus beige (herbarium), lobate, loosely adnate, corticicolous, $12.5 \times 8 \mathrm{~cm}$ broad; lobes irregularly branched, laterally overlapped, 6-9 mm wide; surface lustrous, pruinose in some places, reticulate or cracked, the reticulations giving rise to a pattern resembling a mosaic of areolae, the areolae can develop revolute margins and finally flake off (schizidia), showing the medulla, in the central part of the thallus convex areolae can be seen, usually associated with a strong rugosity of the thallus; apical zone rounded; marginal zone undulate, margin crenate. Maculae distinct, reticulate, laminal, originating areolae mosaics. Cilia black, simple or sometimes squarrose, $0.1-1.6 \times 0.02-0.05 \mathrm{~mm}$, abundant in some lobes. Lacinulae simple or little branched, plane to canaliculated, apex usually acute, sometimes rounded or truncate, $0.5-7 \times 0.2-1.4 \mathrm{~mm}$. Pustulae, soredia and isidia absent. Medulla white. Undersurface not seen (thallus pasted in a paper card).

Apothecia cupuliform to urceolate, lacerate when well-developed, 2-14 $\mathrm{mm}$ in diameter, stipitate, laminal to submarginal, margin smooth to slightly crenate, sometimes denticulate, amphithecium maculate, smooth to scrobiculate, disc pale brown, epruinose, perforate only in some very old apothecia; ascospores ellipsoid, 12.5-15 $\times 8.5-10 \mu \mathrm{m}$, episporium 1-1.5 $\mu \mathrm{m}$. Pycnidia submarginal to laminal, especially abundant in some lacinulae, conspicuous, usually without prominent margin, ostiole black; conidia filiform, $8-25 \times \sim 1 \mu \mathrm{m}$.

Chemistry. Atranorin, chloroatranorin, salazinic acid, consalazinic acid and trace of protocetraric acid (Elix \& Johnston 1988). Cortex K+ yellow, UV-; medulla K+ yellow $\rightarrow$ blood red, $\mathrm{C}-, \mathrm{KC}-, \mathrm{P}+$ strong yellow, $\mathrm{UV}-$.

Remarks. Parmotrema austrocetratum is distinguished by the formation of schizidia (Fig. 8B) and lacinulae, and the presence of salazinic acid. Elix \& Johnston (1988) described the formation process of wrinkles by means of pressured areolae of the upper cortex, which also can flake out, and called them dactyls. However, the more appropriate term is schizidia, as already suggested by Moon et al. (2001), who placed P. austrocetratum as a synonym of $P$. hawaiiense, a position we do not agree with since $P$. hawaiiense does not develop lacinulae, but develops a smooth upper surface and produces smaller conidia $(10-15 \mu \mathrm{m})$. Another close species is the eciliate and pustulate $P$. ruminatum (see comments under this species).

The holotype of $P$. austrocetratum is a well-developed specimen in an excellent state of preservation. Notwithstanding, it is totally glued by the undersurface to a paper card so that it is impossible to describe the underside characters. Near the specimen there is a label with the chemical composition: atranorin, chloroatranorin, salazinic acid (major) and consalazinic acid, determined by TLC. This information differs a little from the published one, where traces of protocetraric acid were also noted.

The isotype (CANB) is also glued by the underside. Unfortunately, as no additional specimens of $P$. austrocetratum were seen, the undersurface features could not be studied.

The correct number of the holotype is J.A. Elix 7979, not J.A. Elix 4645, as published in the protologue (Elix \& Johnston 1988). This aspect was also annotated by Streimann (label with the isotype).

It was very hard to find pycnidia with conidia. After some attempts, very short ones were found (7-12.5 $\mu \mathrm{m})$. However, on a final attempt very long ones (up to $25 \mu \mathrm{m}$ long) appeared. As far as we know, this is a new record in Parmotrema, followed by Parmotrema arteagum (conidia up to $23 \mu \mathrm{m}$, according to Egan 1982).

Distribution. Australia and New Zealand (Elix \& Johnston 1988; Galloway 2007).

Parmotrema austromaculatum Spielmann \& Marcelli, sp. nov.

(Figs 4B, 9A)

\section{MycoBank MB 838179}

Diagnosis: Differs from P. cetratum by the strong reticulate maculae or lobes often hypermaculate, conspicuous lacinulae, wider lobes, longer cilia and the naked, lustrous lower margin of the lobes.

Type: Brazil. Rio Grande do Sul: Municipality of Boqueirão do Leão, Linha Sinimbuzinho, Perau da Nega, 29²0'17.2"S, $52^{\circ} 26^{\prime} 33.6^{\prime \prime} \mathrm{W}, 430 \mathrm{~m}$, saxicolous, left margin of the stream, close to the vertical slope, open place, 23.II.2004, A.A. Spielmann \& L.S. Canêz 1111 (holotype - SP).

Description (based on holotype). Thallus greenish gray, lobate, loosely adnate, saxicolous, $18 \mathrm{~cm}$ broad. Lobes irregularly branched, laterally overlapped to crowded, 5-30 mm wide, surface smooth to reticulately cracked, sometimes pruinose, opaque to sublustrous, becoming notched and reticulately cracked towards the center; apical zone rounded, plane to strongly concave; margin crenate to broadly crenate, ascendant or revolute, undulated; lateral margin usually ascendant and revolute, regular to undulated, often lacinulate. Maculae strong, reticulate or hypermaculate, laminal, originating cracks or not. Cilia black, usually simple, rarely furcated, sinuous, often ascendant, especially at the lobe apices, 1-3.5 $\times 0.03-$ $0.10(-0.15) \mathrm{mm}$, abundant. Lacinulae plane to concave, simple to furcated or irregularly branched, sometimes subpalmate, often spatulate or with the apex enlarged, rounded or concave, or apex acute to truncate, abundant, $0.5-6 \times 0.5-7 \mathrm{~mm}$, lower surface black, brown, or rarely white variegated. Pustules, soredia and isidia absent. Medulla white. Undersurface black, lustrous, mainly smooth to sometimes rugulose or slightly papillate, rarely veined, with cracks; marginal zone dark brown, occasionally black or rarely pale brown or white variegated, lustrous, 1-7 mm wide, naked, with an attenuated limit, 

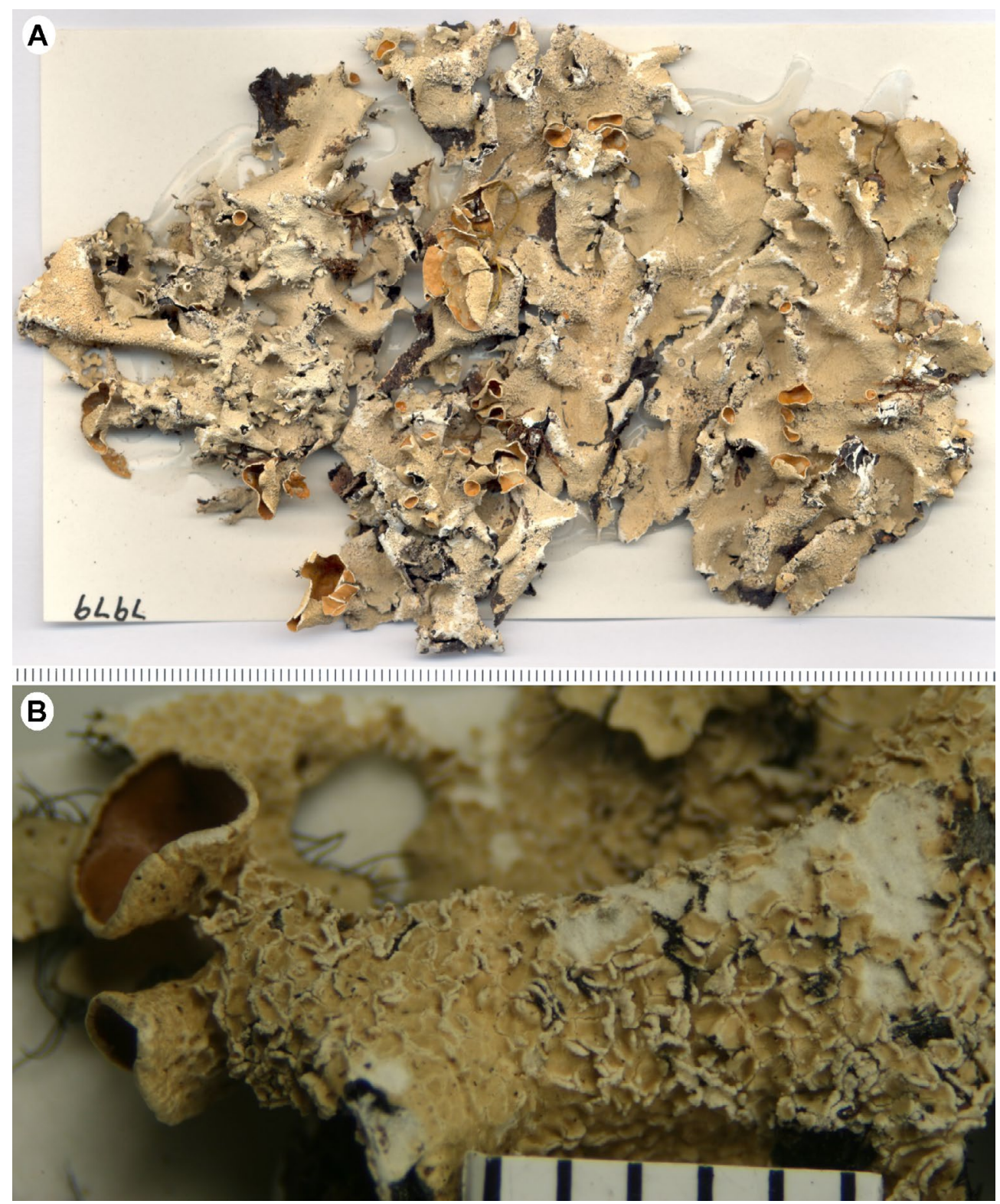

Figure 8. Holotype of Parmotrema austrocetratum (CHR). A - thallus; B - upper surface with schizidia. Scales in milimeters.

smooth to rugulose or papillate; rhizines black, usually simple, sometimes furcated or irregularly branched, 0.3-4 $\times 0.02-0.2 \mathrm{~mm}$, frequent, distributed in groups.

Apothecia concave to cupuliform or \pm urceolate, 2-6 $\mathrm{mm}$ in diameter, stipitate, submarginal, margin smooth to crenulated or incised, amphithecium maculate, smooth to rugose, disc brown, epruinose, entire to lacerated, perforate at maturity; ascospores broadly ellipsoid, $10-12.5 \times 8-9 \mu \mathrm{m}$, episporium $\sim 1 \mu \mathrm{m}$. Pycnidia submarginal, conspicuous, with prominent margin, frequent especially in the lacinulae, ostiole black; conidia filiform, (7.5-) 9-11.5 $\times \sim 1 \mu \mathrm{m}$.

Chemistry. Atranorin, salazinic acid and consalazinic acid. Cortex $\mathrm{K}+$ yellow, UV-; medulla $\mathrm{K}+$ yellow $\rightarrow$ blood red, $\mathrm{C}-, \mathrm{KC}-, \mathrm{P}+$ strong yellow, $\mathrm{UV}-$.

Etymology. Latin austro = south, and macula - stain.

Remarks. Parmotrema austromaculatum is characterized by the strong reticulate maculae, often hypermaculate, conspicuous lacinulae, wide lobes (up to $30 \mathrm{~mm}$ ), long cilia (up to $3.5 \mathrm{~mm}$ ) and the naked lower margin of the lobes. The patter of maculation is similar to that found in P. hypermaculatum (Benatti et al. 2008), a species with imperforate apothecia. It can be confused with to $P$. cetratum, which is rhizinate in the lower margin of the lobes and never hypermaculate, and to Parmotrema eurysacum, which can be differentiated by the lacinulae with submarginal pycnidia ornate with a black outline.

The species is abundant at the type locality. Additional specimens studied revealed only minor differences: thalli varied from 6 to $30 \mathrm{~cm}$ broad. Lacinulae were 40.4-20.0 $\times 0.5-8 \mathrm{~mm}$. Cilia reached up to $5 \mathrm{~mm}$ of length, and conidia were $7.5-14 \mu \mathrm{m}$ long.

Distribution. Known thus far from the type locality, but probably quite frequent in Southern Brazil.

Additional specimens examined. BRAZIL. Rio Grande do Sul: Municipality of Boqueirão do Leão, Linha Sinimbuzinho, 
Perau da Nega, $29^{\circ} 20^{\prime} 02.2^{\prime \prime} \mathrm{S}, 52^{\circ} 26^{\prime} 27.9^{\prime \prime} \mathrm{W}, 440 \mathrm{~m}$ alt., on rock at stream margin, open place, 24.II.2004, A.A. Spielmann \& L.S.

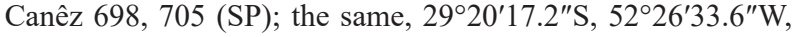
$430 \mathrm{~m}$ alt., saxicolous, left margin of the stream, near the steep slope, open place, 23.II.2004, A.A. Spielmann \& L.S. Canêz 1340, 1341, 1342, 1343, 1344, 1345, 1358, 1365 (SP).

Parmotrema bifidum Spielmann \& Marcelli, sp. nov.

(Figs 9B, 10A-C)

MycoBank MB 838180

Diagnosis: Similar to Parmotrema expansum, but distinguished by the brown underside with a naked and shiny dark brown marginal zone.

Type: Brazil. Mato Grosso: Serra da Chapada [presently Chapada dos Guimarães], Bocca da Serra, ad rupes, 15.VI.1894, G.O.A. Malme (holotype - S!).

Description (based on holotype). Thallus milky grayish, lobate, loosely adnate, saxicolous, $11 \mathrm{~cm}$ broad. Lobes irregularly branched, laterally overlapped, 3-7 mm wide, with a distinct black line, thickened at the sinuses, surface continuous, smooth, lustrous, becoming strongly cracked and sometimes rugose towards the center, the cracks usually perpendicular to the lobe axis; apical zone rounded; margin sinuous-incised, undulated. Maculae strong, effigurate, laminal, originating cracks. Cilia black, simple to usually furcated, sometimes more branched, up to $1 \mathrm{~mm}$ long, usually thick, $0.05-0.15 \mathrm{~mm}$ wide, abundant. Lacinulae, pustules, soredia and isidia absent. Medulla white. Undersurface pale brown, opaque to sublustrous, usually smooth, slightly rugose or papillate in some areas, without cracks; marginal zone dark brown, shiny, 1-3 mm wide, naked, with an attenuated limit, smooth or rarely papillate; rhizines dark brown, simple or less frequently furcated or irregularly branched, up to $2 \mathrm{~mm}$ long, usually thickened, (0.2-) 0.5-0.2 mm wide, abundant, irregularly distributed, leaving several areas naked.

Apothecia cupuliform, 1.5-9 $\mathrm{mm}$ in diameter, substipitate, submarginal, margin usually involute, smooth to irregularly incised, amphithecium maculate, rugose-foveolate, disc pale to dark brown, epruinose, perforate or imperforate; ascospores ellipsoid, 11-14 × 6.5-7.5 $\mu \mathrm{m}$, episporium $0.5-1 \mu \mathrm{m}$. Pycnidia submarginal or sometimes advancing over the lamina, conspicuous, without prominent margin, abundant, ostiole black; conidia short-filiform, $6-10 \times \sim 1 \mu \mathrm{m}$.

Chemistry. Atranorin (minor), chloroatranorin (trace), salazinic acid (major), consalazinic acid (minor), protocetraric acid (trace). Cortex $\mathrm{K}+$ yellow, $\mathrm{UV}-$; medulla $\mathrm{K}+$ yellow $\rightarrow$ blood red, $\mathrm{C}-, \mathrm{KC}-, \mathrm{P}+$ strong yellow, $\mathrm{UV}-$.

Etymology. Latin bifidus $=$ split. Split in the middle, in reference to the cilia.

Remarks. Parmotrema bifidum is distinguished by the thickened furcated cilia, strong effigurate maculae, and the brown underside with a naked and shiny dark brown marginal zone. It must be noted that the under marginal zone is darker than the center, a rare pattern inside Parmotrema with salazinic acid (present also in P. petropoliense).
Parmotrema expansum also develops furcated cilia and effigurate maculae; however, has a distinct shiny jet-black undersurface. Another similar species is the sorediate Parmotrema concors, known from Australia. The shiny under marginal zone and branched cilia can be compared with $P$. lichexanthonicum, which contains lichexanthone and has weak maculae. Strongly effigurate maculae occur in $P$. leucosemothetum, distinguished by the simple longer cilia (up to $3 \mathrm{~mm}$ ).

The cilia of $P$. bifidum resemble those of Parmotrema consors, a common Brazilian species that contains only fatty acids (Spielmann \& Marcelli 2009). On the other hand, in this species the cilia are usually turned down, while in P. bifidum they are prostrate or ascending.

Lynge (1914), when describing Parmelia cetrata subsp. radiata, listed two specimens, one from Paraguay and another from Brazil. Later on, Hale (1960) made the typification of this taxon choosing the specimen from Paraguay as lectotype. Hale \& Fletcher (1990) placed $P$. cetrata subsp. radiata as synonymous of Parmotrema cetratum. This taxon actually constitutes a good species, $P$. radiatum (see comments under it). The Brazilian syntype is not conspecific with it, and it is here being described as $P$. bifidum.

Distribution. Known only from the type locality.

Parmotrema cetratum (Ach.) Hale, Phytologia 28(4): 335. 1974.

Basionym: Parmelia cetrata Ach., Synopsis Methodica Lichenum: 198. 1814.

Type: USA Pennsylvania: Muhlenberg s.n. (lectotype H-ACH 1329!; isolectotype - UPS, photo!).

$\equiv$ Rimelia cetrata (Ach.) Hale \& Fletcher, The Bryologist 93(1): 26. 1990.

= Parmelia perforata Ach. var. corniculata Kremp. Videnskabelige meddelelser fra den Naturhistoriske forening i Kjöbenhavn 5: 11. 1873.

Type: Brazil. Rio de Janeiro: Warming 323 (lectotype - M!).

$\equiv$ Parmelia cetrata var. corniculata (Kremp.) Müll. Arg., Hedwigia 30: 228. 1891. According to Hale \& Fletcher (1990).

Description (based on lectotype). Thallus brownish (herbarium), lobate, corticicolous (fide Acharius 1814), $3.5 \mathrm{~cm}$ broad. Lobes irregularly branched, 2-5 mm wide, surface continuous, smooth, lustrous, becoming reticulately cracked towards the center; apical zone slightly rounded to acute; margin smooth, plain to slightly undulated. Maculae distinct, reticulate, laminal, originating cracks. Cilia black, simple to furcated, up to $1.3 \mathrm{~mm}$ long, $0.02-$ $0.05(-0.1) \mathrm{mm}$ wide, abundant. Lacinulae absent (present in the isolectotype). Pustules, soredia and isidia absent. Medulla white. Undersurface black, lustrous, smooth, with cracks; marginal zone absent; rhizines black, apparently simple or squarrose, up to $1 \mathrm{~mm}$ long, abundant.

Apothecium plane (probably pressed), $1.7 \mathrm{~mm}$ in diameter, probably stipitate and laminal, margin incise to deeply incised, disc blackish brown, epruinose, perforate; ascospores ellipsoid, 12.5-15 × 8-10 $\mu \mathrm{m}$, episporium $1-1.5 \mu \mathrm{m}$. Pycnidia laminal, conspicuous, without prominent margin, frequent, ostiole black; conidia not 


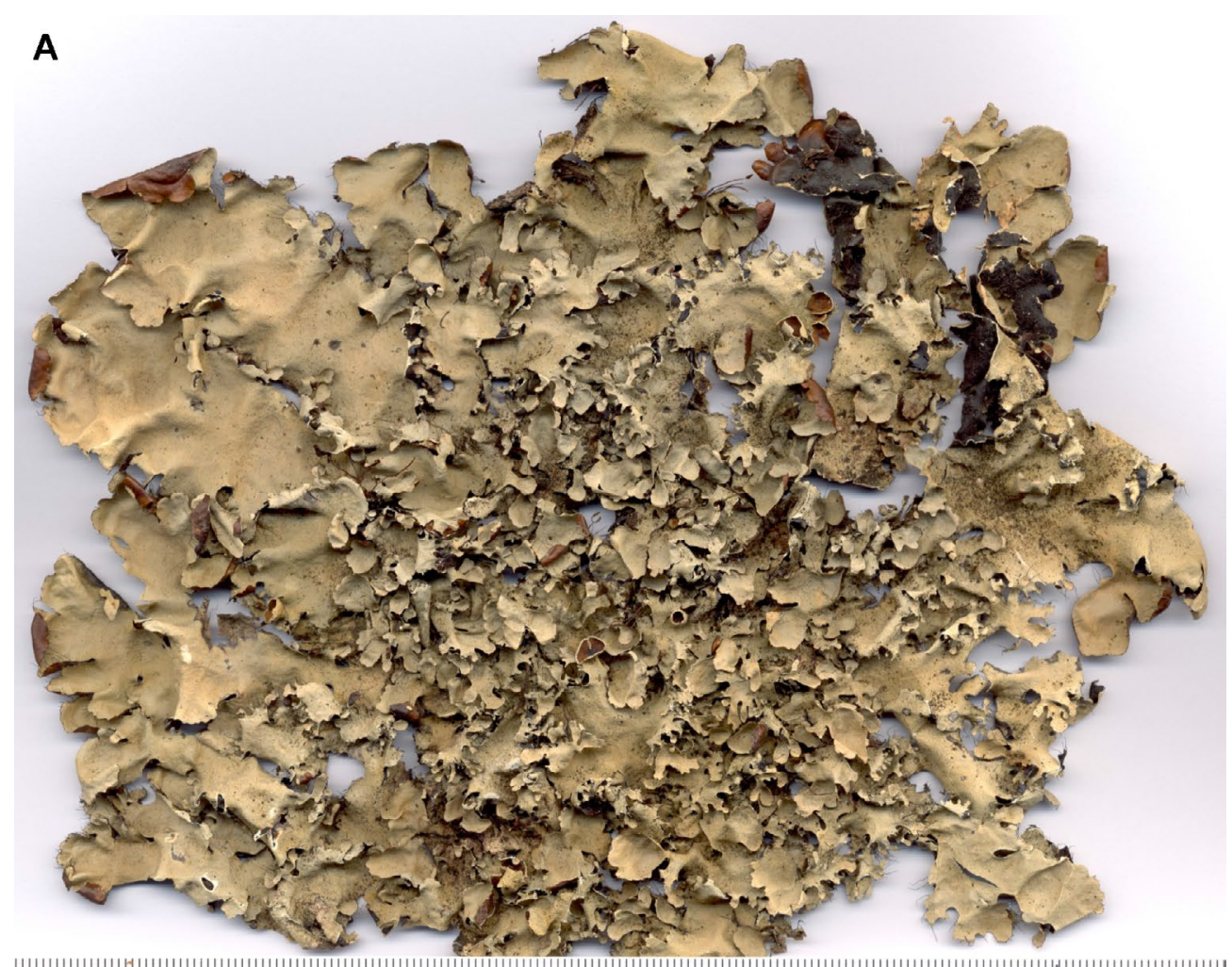

||||||||||||||||||||||||||||||||||||||||||||||||||||||||||||||||||||||||||||||||||||||||||||||||||||||||||||||||||||||||||||||||||||||||||||||||||||||||||||||||||||||||||||||||||

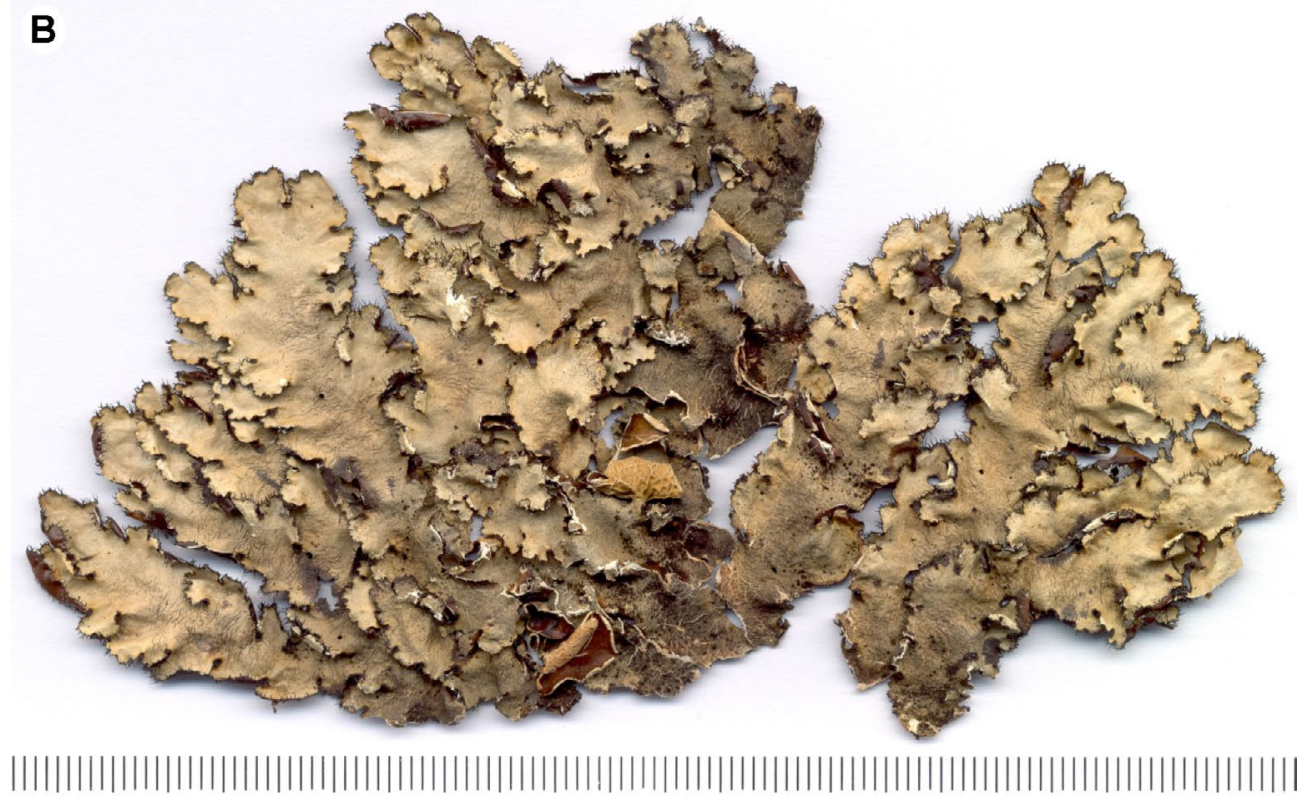

Figure 9. A - holotype of Parmotrema austromaculatum (SP); B - holotype of Parmotrema bifidum (S). Scales in milimeters.

found (10 pycnidia examined), but the conidia of Parmelia perforata var. corniculata (lectotype) are filiform, $9-12.5 \times \sim 1 \mu \mathrm{m}$.

Chemistry. Atranorin (minor), chloroatranorin (trace), salazinic acid (major), consalazinic acid (minor). Cortex $\mathrm{K}+$ yellow, UV-; medulla $\mathrm{K}+$ yellow $\rightarrow$ blood red, $\mathrm{C}-$, $\mathrm{KC}-, \mathrm{P}+$ strong yellow, $\mathrm{UV}-$.

Remarks. Parmotrema cetratum is recognized by the reticulate maculae, the absence of propagules, the presence of salazinic acid, and lobate thallus, usually with lacinulae (Fig. 11B). This species is part of a complex and misunderstood group, and several good, but frequently abundantly lacinulate species has been synonymized under $P$. cetratum based on the combination of a small set of characters observed.

While studying the rich lichenized mycota of Southern Brazil, Fleig (1997) and Eliasaro (2001) found significant differences in the maculation of the specimens. Spielmann (2005) asserted that some morphologically distinct specimens could be good taxa. Divakar et al. (2005) through molecular data, also pointed out the necessity to revise $P$. cetratum and its synonyms, since specimens from Costa Rica tentatively identified as this species were morphologically and molecularly distinct from the Uruguayan ones. 

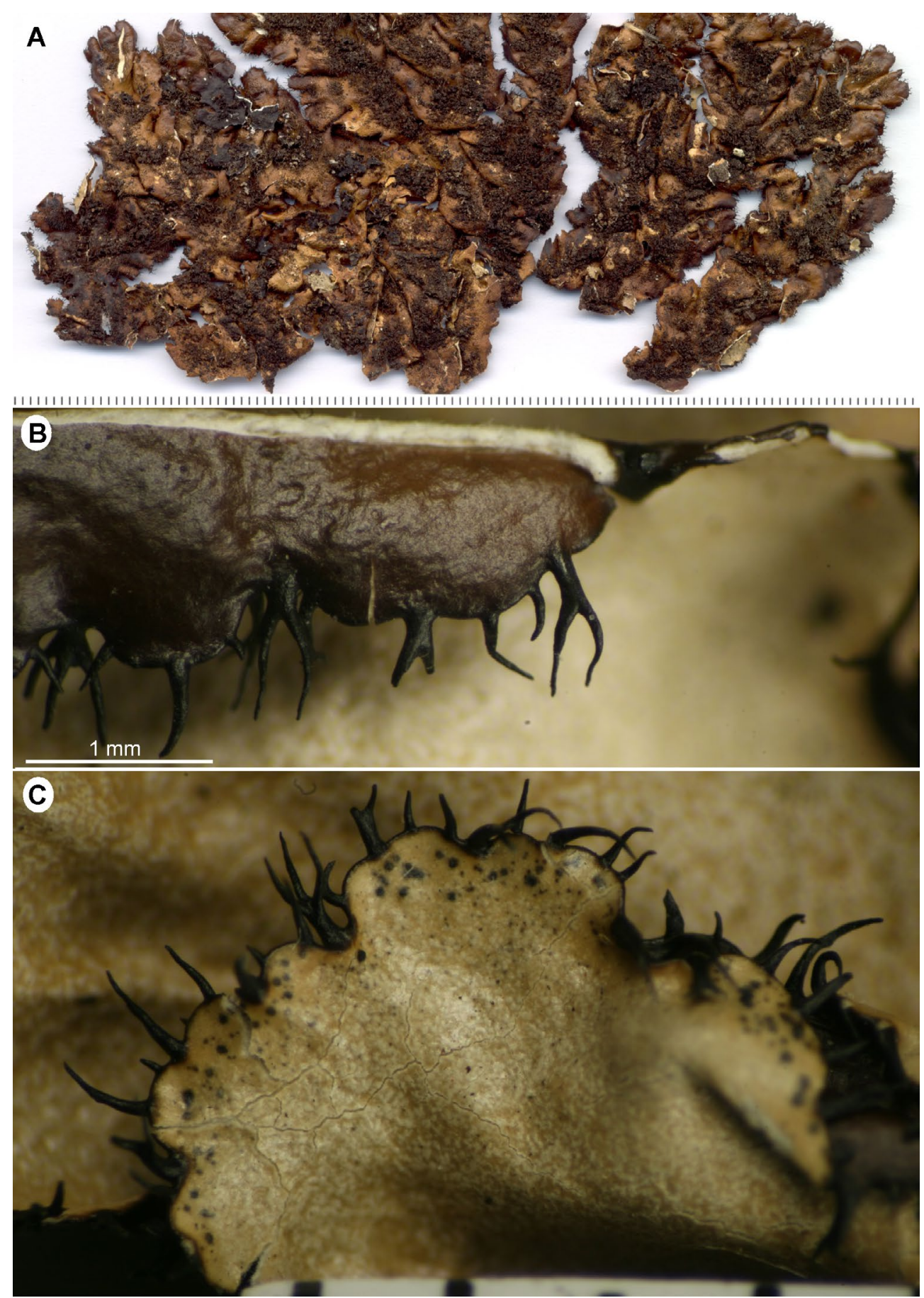

Figure 10. Holotype of Parmotrema bifidum (S). A - undersurface; B - furcated cilia; C - uppersurface showing the strong effigurate maculae and robust, tapering cilia. Scales in milimeters, except as indicated.

The revision of the types of the synonyms showed that significant morphological differences were hidden under the name $P$. cetratum, a species that probably is much more restricted in its distribution, maybe centered in Eastern North America and perhaps extending to other temperate climates. Therefore, we are proposing some synonyms (see Hale \& Fletcher 1990) as distinct species: Parmotrema acanthifolium, P. radiatum and $P$. warmingii. See the comments under each of these taxa for more detailed information.

Other synonyms are placed as nomina inquirenda, since the types were not seen or, chiefly because their size or preservation condition, do not have sufficient well-preserved characters to clarify their status: Parmelia cinerascens var. saxicola, P. maura, P. menziesii, P. perforata var. microspora, $P$. perforata var. replicata and $P$. polita.

However, there is still a large number of specimens with divergent features (like very short cilia, imperforate apothecia, etc.) to which the only available name is 'Parmotrema cetratum'. Undoubtedly, only a dedicated revision to this species complex can help to delimitate their taxa more properly.

The lectotype of P. cetratum $(\mathrm{H})$ is a poor specimen, $3.5 \mathrm{~cm}$ broad, although with a well-developed apothecium, mixed with one Parmelia sp. and glued on a paper. It was 
consequently very difficult to study the undersurface. Moreover, the interpretation of thallus morphology was difficult. We called the thallus lobate, although it could be only part of a larger lobed specimen since signs of another glued specimen are visible.

Unfortunately, conidia were not found in the lectotype, and so we referred to the conidial data from the lectotype of Parmelia perforata var. corniculata. Future studies including the isolectotype (UPS) and additional specimens recently discovered in the PH Herbarium (Lendemer \& Hewitt 2002) are fundamental to verify this feature since Hale \& Fletcher (1990) did not inform the specimen from which the ascospores and conidial data were furnished. Also, the type from Parmelia cetrata is from the USA, while that of $P$. perforata var. corniculata is from Brazil. This last specimen is well-developed and undoubtedly closer to the concept more commonly used today for Parmotrema cetratum. It has ascospores 15-17.5 $\times 10-11.5 \mu \mathrm{m}$, the episporium $1.5 \mu \mathrm{m}$ thick.

The herbarium UPS sent a photograph of the isolectotype of $P$. cetratum, represented by a quite larger thallus, apparently without apothecia, but with more developed lacinulae. It seems to agree well with the lectotype. The same Parmelia sp. is also growing with the specimen so it is probably from the same locality or maybe it was before glued together with the lectotype.

The typification of $P$. cetratum was made by Hale \& Fletcher (1990). We do not know, however, how these
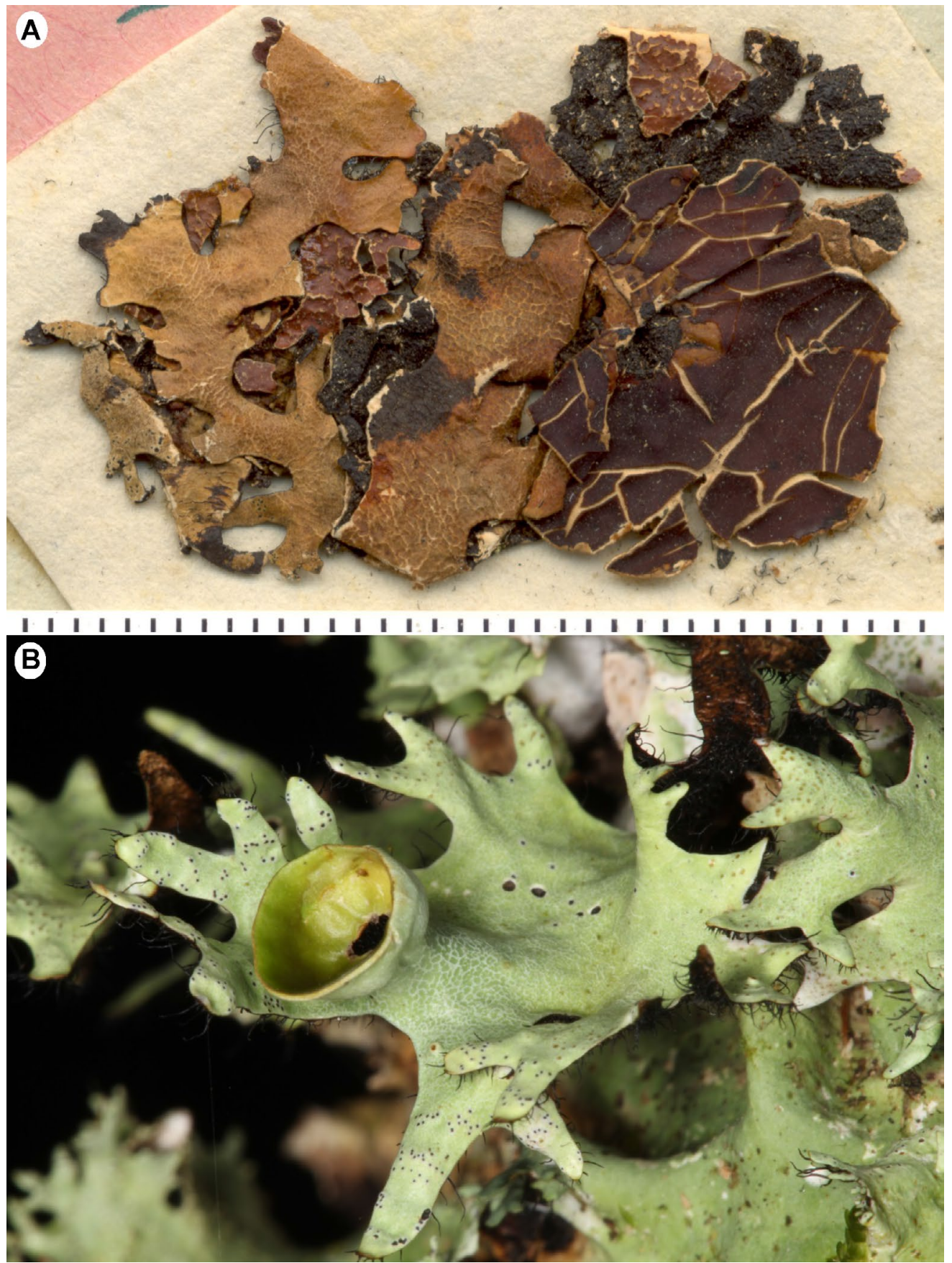

Figure 11. Parmotrema cetratum. A - lectotype $(\mathrm{H}-\mathrm{ACH}) ; \mathrm{B}$ - fresh specimen from Brazil, showing perforate apothecium, reticulate maculae and lacinulae (Spielmann 11227). Scales in milimeters. 
authors concluded that the type locality was Pennsylvania since both the protologue and the lectotype $(\mathrm{H})$ indicate only 'America Septentrionalis'.

As we are proposing changes in the circumscription of this species, at present, we cannot have a real idea of the 'true' distribution of Parmotrema cetratum. The references below are maintained, however, as a guide to the current literature on this name.

Distribution. North America (Hale \& Fletcher 1990; Brodo et al. 2001; Nash \& Elix 2002c; Esslinger 2008; Egan et al. 2016), Central America (Feuerer 2008), South America (Hale \& Fletcher 1990), Africa (Krog \& Swinscow 1981; Swinscow \& Krog 1988; Hale \& Fletcher 1990; Aptroot 1991), Asia (Awasthi 1976; Kurokawa \& Lai 2001), and Oceania (Elix 1994; Galloway 1985; Malcolm \& Galloway 1997; Louwhoff \& Elix 1999),

In South America it is known from Venezuela (Vareschi 1973), Peru (Feuerer 2008), Bolivia (Feuerer et al. 1998), Brazil (Marcelli 2004), Paraguay (Lynge 1914), Uruguay (Lynge 1924; Osorio 1972, 1992b, 1995, 2003), Argentina (Lynge 1924; Osorio 1976; Hale \& Fletcher 1990; Adler 1992; Calvelo \& Liberatore 2002) and Chile (Feuerer 2008). In Brazil it was recorded from Minas Gerais (Lynge 1914, 1924; Hale \& Fletcher 1990; Ribeiro 1998), Mato Grosso (Lynge 1914), Paraná (Osorio 1977a,b; Fleig 1997; Eliasaro 2001), Rio de Janeiro (Lynge 1924), Rio Grande do Sul (Spielmann 2006), Santa Catarina (Marcelli 1992; Osorio 1997; Fleig 1997; Gumboski \& Eliasaro 2011) and São Paulo (Marcelli 1991, 1992; Ribeiro 1998; Benatti \& Marcelli 2008).

Additional specimens examined. BRAZIL. Rio Grande do Sul: Caraá. APA Municipal do Caraá, Trilha da nascente do rio dos Sinos, Comunidade de Colônia Fraga, 21.IX.2014, $29^{\circ} 42^{\prime} 27.69^{\prime \prime}$ S, $50^{\circ} 17^{\prime} 28.70^{\prime \prime} \mathrm{W}, 410 \mathrm{~m}$ alt., A.A. Spielmann, S.A. Martins, N.M. Koch, E. Gumboski \& R. Lücking 11227 (CGMS). PARAGUAY. Chaco: Estancia Elsita on Rio Monte Lindo Chico, c. 250 Km W. of Concepción 01.VI.1947, C. Chr. Olrog., L13348 (S).

Parmotrema clavuliferum (Räsänen) Streimann, Bibliotheca Lichenologica 22: 93. 1986.

(Fig. 12)

Basionym: Parmelia clavulifera Räsänen, Annales Botanici Societatis Zoologicae Botanicae Fennicae 20(3): 4.1944.

Type: Oceania. Tahiti: ad corticem arboris, 1868, Dr. med. Bouffon vel E. Vieillard (lectotype - H!; paratype - H!).

$\equiv$ Rimelia clavulifera (Räsänen) Kurok., Journal of Japanese Botany 66(3): 158. 1991.

= Parmelia urceolata var. subcetrata Müll. Arg., Flora 66: 46. 1883.

Type: Australia. Queensland: prope Toowoomba, 1881, Hartmann s.n. (lectotype - G!).

Description (based on lectotype). Thallus brownish (herbarium), lobate, apparently loosely adnate (pasted in a paper card), corticicolous, $12.5 \mathrm{~cm}$ broad. Lobes irregularly branched, more or less crowded, 2-7.5 mm wide, surface continuous to cracked, smooth to irregularly pitted (i.e., with small depressions), lustrous, becoming strongly cracked in the center; apical zone rounded; margin crenate, plane to undulated. Lacinulae simple to dichotomous, localized mainly in the center of the thallus, usually canaliculated and 'closing' (i.e., joining the margins and becoming solid) from the apices to the bases, apex acute and with a black tip when esorediate, capitate to extensive and finally 'T-like' when sorediate, $0.5-4(-7.5) \times 0.2-1 \mathrm{~mm}$; undersurface cream color, erhizinate or with sparse rhizines. Maculae distinct, reticulate, laminal, originating cracks. Cilia black, simple or rarely subsquarrose, $0.2-1.5 \times 0.02-0.04 \mathrm{~mm}$, few. Soralia capitate to sometimes growing backwards, on the lacinulae apices; soredia subgranular to farinose. Isidia and pustules absent. Medulla white. Undersurface (difficult to analyze, since the thallus is pasted on a paper card) black, lustrous, slightly rugose to papillate; marginal zone brown to dark brown, lustrous, 2.5-3 mm wide, naked to more usually rhizinate, with an attenuated limit, papillate; rhizines black, simple or sometimes squarrose, up to $3 \mathrm{~mm}$ long, $\sim 0.05 \mathrm{~mm}$ wide, abundant, distributed in groups.

Apothecia absent. Pycnidia laminal, mainly on the lacinulae, conspicuous, frequent, ostiole black; conidia filiform, 7.5-12.5 $\times \sim 1 \mu \mathrm{m}$.

Chemistry. Atranorin (minor), chloroatranorin (trace), salazinic acid (major), consalazinic acid (minor). Cortex $\mathrm{K}+$ yellow, UV-; medulla $\mathrm{K}+$ yellow $\rightarrow$ blood red, $\mathrm{C}-$, $\mathrm{KC}-, \mathrm{P}+$ strong yellow, UV-.

Remarks. Parmotrema clavuliferum is recognized by the reticulate maculae and the abundant closed lacinulae with the soralia at the apices. Some authors already realized that it is different from $P$. reticulatum (e.g. Streimann 1986; Kurokawa 1991; Moon et al. 2001; Elix 2001; Killmann \& Fischer 2005), while others (e.g. Awasthi 1976; Divakar et al. 2001) concluded that it is conspecific with $P$. reticulatum. Based on the types here studied, we can conclude they are distinct species. In a recent study, Ahn \& Moon (2016) found molecular support for this conclusion.

In a recent study based on Galapagos Islands specimens (Bungartz \& Spielmann 2019) we realized that the distinct laciniate lobes with capitate soralia, present in both Parmotrema clavuliferum and $P$. marcellianum, could be recognized by a different name, 'clavulae'. This constitutes an additional morphological feature to distinguish these species from $P$. reticulatum. In $P$. marcellianum, the lobes are abundantly ciliate and the undersurface of the clavulae are mostly blackened, while in P. clavuliferum the lobes are unfrequently ciliate and the clavulae are usually white (cream color in herbarium specimens) below.

The lectotype $(\mathrm{H})$ is well-preserved and developed. The cilia are very few. However, many rhizines protrude from the lower surface and look like cilia. The thallus is pasted on a paper card, so the description of the undersurface was not complete. Although a small portion of one thallus, also numbered ' 2 ' like the major one, is pasted by the upper surface. It is difficult to assign it to Parmelia clavulifera on the absence of lacinulae. So we preferred to take the data only from the bigger thallus.

The correct information from the types is not clear. Räsänen (1944) asserted that the collections were from Tahiti made by Dr. med. Bouffon or E. Vieillard. Hale 
\& Fletcher (1990) also listed Tahiti, but only Vieillard as the collector. In the lectotype packet there is an annotation by T. Ahti, dated February 2002, indicating that the collector is probably E. Vieillard and the locality is possibly New Caledonia.

The paratype $(\mathrm{H})$ is represented by a more laciniate, robust thallus (the lectotype is more delicate), with rhizines strongly squarrose-branched. The cilia also are more distinctly squarrose than that of the lectotype.
The lacinulae are similar, however, and clearly assigns this species within the circumscription of Parmelia clavulifera.

The lectotype of Parmelia urceolata var. subcetrata (G) agrees well with Parmotrema clavuliferum, both morphologically and chemically, and although it was called 'holotype' by Sammy (1985), we are following Hale \& Fletcher (1990) in their typification, since in the protologue (Müller Argoviensis 1883) it is clear that another

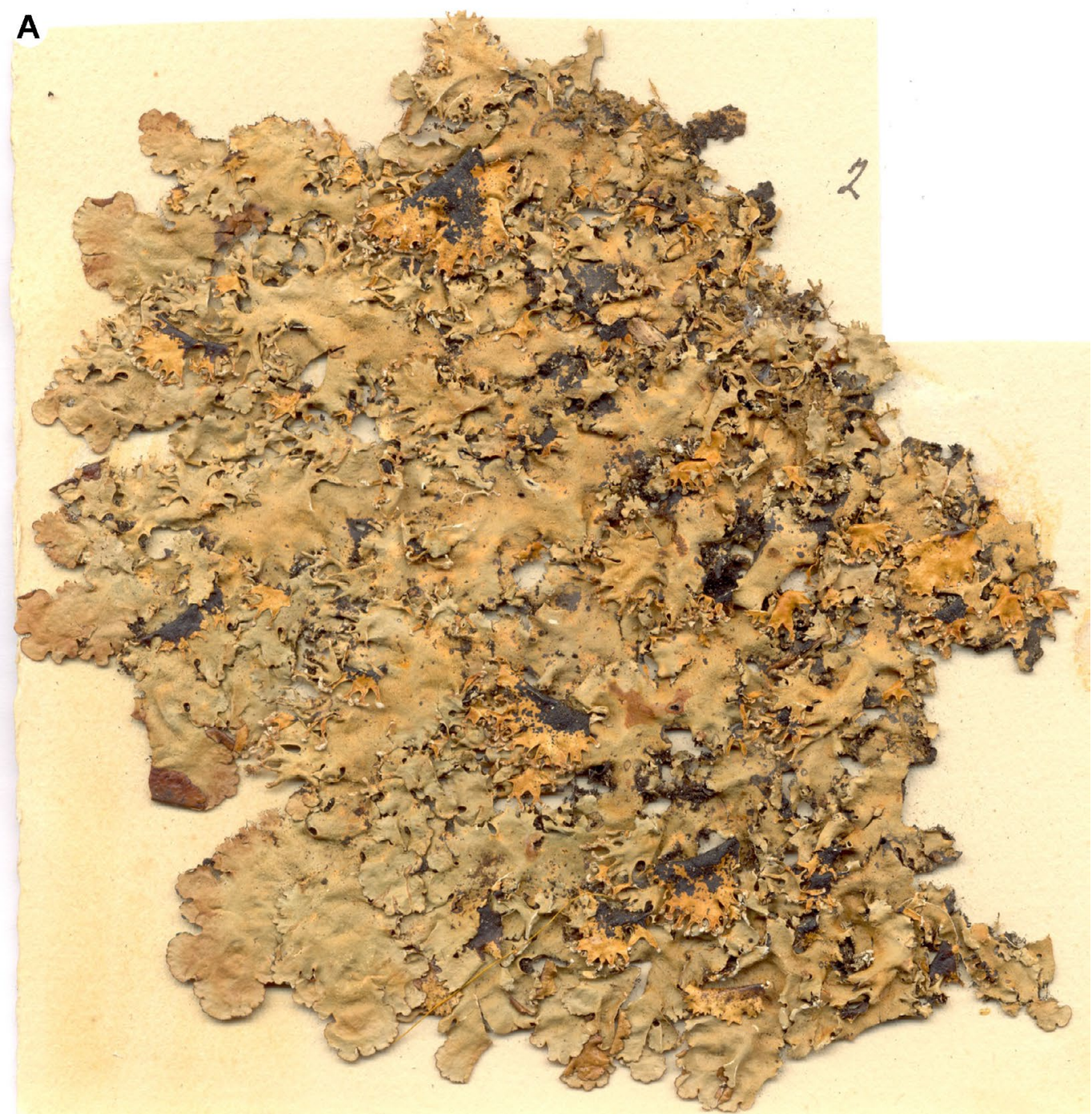

|||||||||||||||||||||||||||||||||||||||||||||||||||||||||||||||||||||||||||||||||||||||||||||||||||||||||||||||||||||
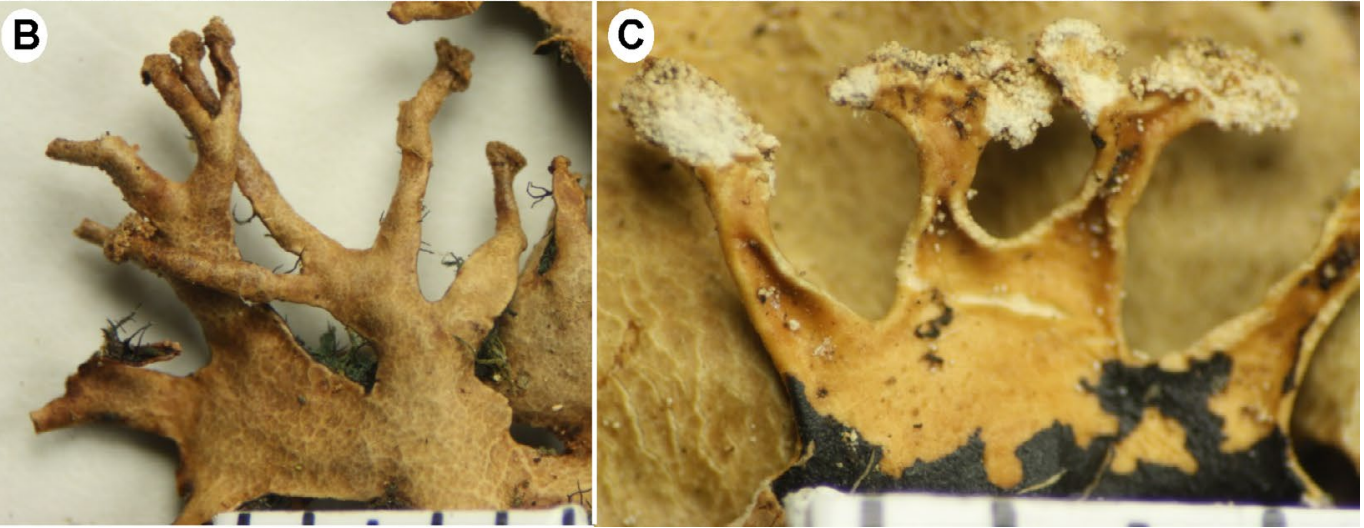

Figure 12. Parmotrema clavuliferum. A - lectotype $(\mathrm{H})$; B - paratype $(\mathrm{H})$, showing the lacinulae; $\mathrm{C}$ - lectotype $(\mathrm{H})$ showing the undersurface of lacinulae. Scales in milimeters. 
specimen was also seen ('ad Twofold Bay'). This taxon was transferred from the synonymy of $P$. reticulatum to P. clavuliferum. Unfortunately, apothecia are absent, and conidia were not found ( 20 pycnidia examined).

Several records from Brazil (e.g. Spielmann 2005, Benatti 2005; Jungbluth 2006) were based on different lichens that were not yet studied in detail by us. Actually, they can represent a different, although widely distributed species (see comments under $P$. cetrata $\mathrm{f}$. sorediifera in the Nomina inquirenda).

Distribution. Hawaii (Moon et al. 2001), Galapagos Islands (Bungartz \& Spielmann 2019), Asia (Feuerer 2008; Ohmura et al. 2012; Ahn \& Moon 2016), Oceania (Lamb 1963; Feuerer 2008), and Brazil. In Brazil, it was recorded from MG (Barros \& Xavier Filho 1972), RS (Spielmann \& Marcelli 2009) and SP (Barros \& Xavier Filho 1972; Jungbluth 2006; Benatti \& Marcelli 2008).

Parmotrema clercianum Spielmann, sp. nov.

(Figs 13, 14A)

MycoBank MB 838181

Diagnosis: Differs from Parmotrema convolutum by the production of salazinic acid and the lobes markedly maculate.

Type: Brazil. Mato Grosso do Sul: Municipality of Jaraguari, Furnas do Dionísio, $20^{\circ} 08^{\prime} 54.3^{\prime \prime} \mathrm{S}, 54^{\circ} 34^{\prime} 15^{\prime \prime} \mathrm{W}, 430 \mathrm{~m}$ alt., corticicolous, inside Cerrado forest, slightly shaded, 15.VI.2012, A.A. Spielmann 11000 (holotype - CGMS).

Description (based on holotype). Thallus subcoriaceous, greenish grey, lobate, loosely adnate, corticicolous, $16 \mathrm{~cm}$ broad. Lobes subdichotomously branched, strongly convolute, and discrete, quite crowded in the center, 2-10 mm wide, surface continuous, smooth to slightly rugose, lustrous to sublustrous, becoming slightly rugose and reticulately cracked towards the center; apical zone rounded; margin smooth to crenate, plane to undulated. Maculae distinct, extensive (hypermaculate) in the lobe apices, becoming reticulate to mainly pseudoreticulate towards the center of the thallus, sometimes originating cracks. Cilia inconspicuous, black, simple or rarely squarrose, $0.1-0.3 \times 0.02-0.05 \mathrm{~mm}$, rare. Lacinules, pustules, soredia and isidia absent. Medulla white. Undersurface black, lustrous, rugose, markedly papillate, with or without cracks; marginal zone brown, lustrous, 0.5-2,5 mm wide, naked, with attenuated limit, smooth to rugose; rhizines black, simple to squarrose, up to $0.1-1.3 \times 0.02-0.15 \mathrm{~mm}$, abundant to tomentose, evenly distributed.

Apothecia urceolate, $1.4-8 \mathrm{~mm}$ in diameter, stipitate, laminal to submarginal on the lobe apices, margin smooth to crenate, amphithecium maculate, smooth to rugose, disc brown, epruinose, perforate at maturity; ascospores ellipsoid to broadly ellipsoid, $12-18 \times 7-8 \mu \mathrm{m}$, episporium $\sim 1 \mu \mathrm{m}$. Pycnidia submarginal, conspicuous, usually with prominent margin, abundant only in the apotheciate lobes, elsewhere absent, ostiole black; conidia filiform, $10-12.5 \times \sim 1 \mu \mathrm{m}$.

Chemistry. Atranorin (minor), salazinic acid (major), consalazinic acid (minor) [chemical determination by Neli

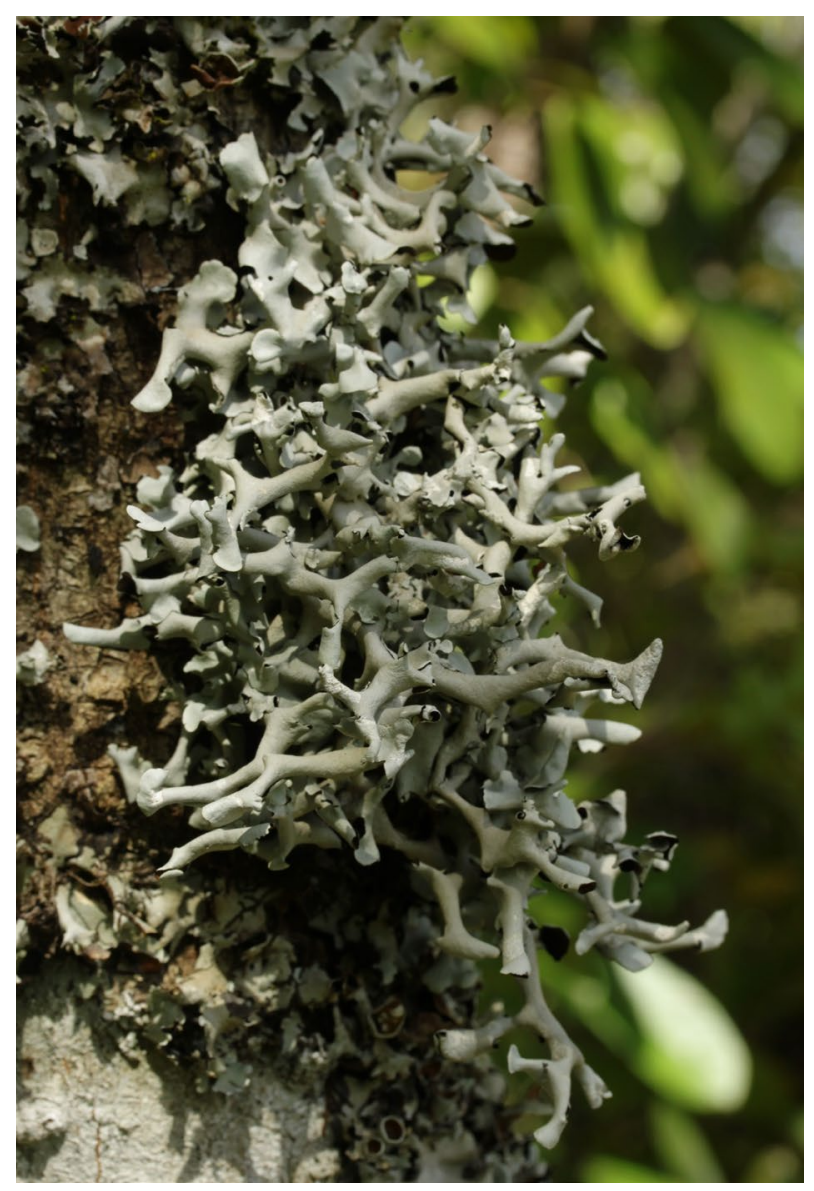

Figure 13. Holotype of Parmotrema clercianum (CGMS) in the natural habitat (Brazilian Cerrado).

K. Honda]. Cortex $\mathrm{K}+$ yellow, UV-; medulla $\mathrm{K}+$ yellow $\rightarrow$ blood red, $\mathrm{C}-$, $\mathrm{KC}-$, $\mathrm{P}+$ strong yellow, $\mathrm{UV}-$.

Etymology. The name of this species is dedicated to Philippe Clerc, a great lichenologist and herbarium manager, who helped to make several types of Parmotrema available for this study. Philippe also influenced Brazilian lichenology in particular for accepting Camille Truong and Alice Gerlach as his students, then advancing the knowledge of Usnea.

Remarks. Parmotrema clercianum is quite easy to recognize because of the markedly convolute lobes, unique in Parmotrema with salazinic acid. The most similar species is Parmotrema convolutum, an Australian endemic that differs by the chemistry (stictic acid, major, without salazinic acid) and the absence of maculae (Elix \& Johnston 1988).

Distribution. Known only from the type collection in Mato Grosso do Sul, Brazil.

Parmotrema concors (Kremp.) Spielmann \& Marcelli, comb. nov.

(Figs 14B, 15A)

MycoBank MB 838185

Basionym: Parmelia concors Kremp., Verhandlungen der zoologisch-botanischen Gesellschaft in Wien 30: 329-342. 1881.

Type: Australia, Kings Island, on bark, Neate s.n. (holotype-M!). 
Description (based on holotype). Thallus brownish (herbarium), lobate, loosely adnate, corticicolous, $9 \times 7 \mathrm{~cm}$. Lobes irregularly branched, crowded, (2.5-) 4-7 mm wide, surface continuous or subscrobiculate, sometimes cracked, smooth, lustrous, becoming strongly cracked in the center; apical zone rounded; margin crenate to sublacinulate, undulated. Lacinulae rare, hardly distinct, often simple or bifurcate, sometimes spatulate, localized mainly in the thallus center, usually plane, apex rounded or acute, $1-2.5 \times 0.5-2 \mathrm{~mm}$. Maculae distinct, effigurate, laminal, forming dense groups and sometimes assuming a reticulate look in the lobe apices. Cilia black, often stout and spiky, straight or curved, simple to furcated, 0.2-1.5 $\times 0.02-0.1 \mathrm{~mm}$, abundant. Pustules and isidia absent. Soralia usually brown, labriform to growing backwards, usually subapical and submarginal turning lobes margins involute, or in the lacinulae apices, or sometimes orbicular and laminal; soredia granular. Medulla pale salmon (maybe herbarium color - possibly white when fresh). Undersurface black, lustrous, rugose, papillate, with cracks; marginal zone dark brown, lustrous, 1-3 mm wide, naked, with a attenuated limit, smooth to rugose or finely papillate; rhizines dimorphic, black or sometimes with brown apices, simple or rarely branched, slender or thickened, $0.2-2 \times 0.01-0.15 \mathrm{~mm}$, abundant, almost evenly distributed.
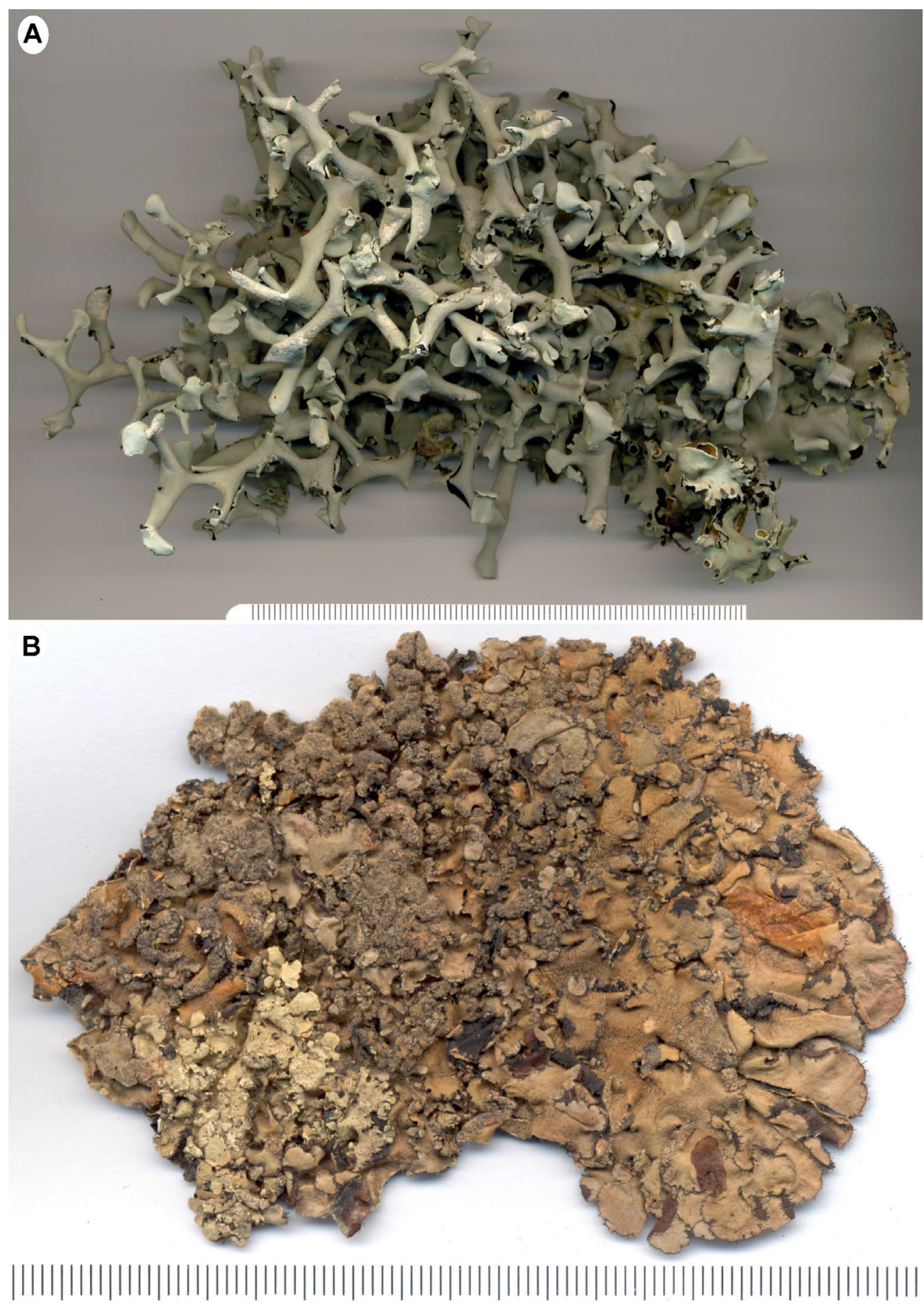

Figure 14. A - holotype of Parmotrema clercianum (CGMS); B - holotype of Parmotrema concors (M). Scales in milimeters. 
Apothecia unknown. Pycnidia not found, although numerous black, submarginal spots are present, yet without conidia.

Chemistry. Atranorin (minor), chloroatranorin (trace), salazinic acid (major), consalazinic acid (minor). Cortex $\mathrm{K}+$ yellow, $\mathrm{UV}-$; medulla $\mathrm{K}+$ yellow $\rightarrow$ blood red, $\mathrm{C}-$, $\mathrm{KC}-, \mathrm{P}+$ strong yellow, UV-.

Remarks. Parmotrema concors can be distinguished by the effigurate maculae, the naked under margin and the spiky, often furcated cilia. This species was treated as a synonym under P. reticulatum (Hale \& Fletcher 1990). Nevertheless, the effigurate maculae, the thickened, often bifurcate cilia, and the dimorphic rhizines, leave no doubt that it is a typical Canomaculina in the Elix (1997) sense. It also has a distinct naked brown marginal zone. Parmotrema reticulatum has slender cilia, sometimes with a small lateral branch, but not furcated at all, and a rhizinate marginal zone with a very narrow brown naked margin. One species that share some features in common with $P$. concors is the esorediate $P$. bifidum.

Distribution. Australia (Krempelhuber 1881; Hale \& Fletcher 1990).

Parmotrema concurrens Hale, Mycotaxon 5(2): 432. 1977

(Fig. 15B)

Type: Brazil. Pernambuco: Buíque, May 1970, saxicolous, L. Xavier Filho 752 (holotype - US!).

Description (based on holotype). Thallus grayish, lobate, loosely adnate, saxicolous, pieces up to $5 \mathrm{~cm}$ broad. Lobes irregularly branched, laterally overlapped to \pm crowded, 3-10 mm wide, surface continuous, smooth, sublustrous to opaque, sometimes becoming irregularly cracked in the center; apical zone rounded; margin crenate to sublacinulate, undulated. Maculae absent. Cilia black, simple, up to $1 \mathrm{~mm}$ long, 0.02-0.05 mm wide, few. Lacinulae, pustules and soredia absent. Isidia concolor to the thallus, apex dark brown to black, usually simple, sometimes branched or aggregated in small coralloid formations, up to $0.3 \mathrm{~mm}$ high, $0.05-0.2 \mathrm{~mm}$ wide, erect, firm to friable, apex rarely ciliate, laminal to marginal. Medulla white. Undersurface black, opaque, usually finely rugulose, less frequently smooth or papillate, with cracks; marginal zone brown or rarely pale brown, sublustrous, $1-4 \mathrm{~mm}$ wide, naked, with an attenuated limit, smooth, papillate or slightly rugose; rhizines black, simple or rarely furcated or irregularly branched, up to $2 \mathrm{~mm}$ long, $0.02-0.1 \mathrm{~mm}$ wide, frequent, distributed in groups.

Apothecia absent. Pycnidia submarginal or laminal, conspicuous, with or without prominent margin, frequent, ostiole black; conidia short-filiform, 6-10 $\times \sim 1 \mu \mathrm{m}$.

Chemistry. Atranorin (minor), chloroatranorin (minor), salazinic acid (major), consalazinic acid (minor), gyrophoric acid (minor), hypoconstictic acid (minor), norhypoconstictic acid (minor). Cortex $\mathrm{K}+$ yellow, UV-; medulla $\mathrm{K}+$ yellow $\rightarrow$ blood red, $\mathrm{C}-, \mathrm{KC}-, \mathrm{P}+$ strong yellow, UV-.
Remarks. Parmotrema concurrens is characterized by the isidiate thallus without maculae, the unfrequent cilia to rare cilia and the combination of salazinic acid, gyrophoric acid and hypoconstictic acid and allied in the medulla. The similar P. ultralucens can be distinguished by the presence of lichexanthone (medulla UV+ yellow) and absence of gyrophoric acid. It also can resemble some saxicolous $P$. tinctorum with narrow lobes, although not related at all, since this last species is eciliate and has lecanoric acid (Hale 1965).

The holotype collection is formed by several thalli or parts of the same thallus. Hale (1977) reported in the protologue thallus $5-8 \mathrm{~cm}$ broad, however, it is possible that he included measurements from the additional examined specimens. The medulla is slightly rose in some areas, perhaps an effect of the decomposition of the salazinic acid.

A description based on several specimens, including apotheciate ones, can be found in Buril (2015).

Distribution. Venezuela (Feuerer 2008), and Brazil, where it was reported from Pernambuco (Hale 1977, Buril 2015).

Additional specimens examined. BRAZIL. Pernambuco: Caruaru, saxicolous, 12 April 1957, E.B. Correia, Universidade do Recife, Instituto de Micologia, 11656, 11658 (US).

Parmotrema coralliforme (Hale) Hale, Phytologia 28(4): 335. 1974

(Figs 4A, 16A)

Basionym: Parmelia coralliformis Hale, Contributions from the United States National Herbarium 36(5): 324. 1965.

Type: Mexico. Chiapas: Mature pine forest on mountainside, 2340 m alt., $18 \mathrm{Km}$ southeast of San Cristóbal on highway 190, on deciduous tree, 24.III.1960, M.E. Hale \& T.R. Soderstrom 20287 (holotype - US!; isotypes - REN, S!).

Description (based on holotype). Thallus pale brownish (herbarium), lobate, loosely adnate, corticicolous, $12.5 \mathrm{~cm}$ broad. Lobes irregularly branched, laterally overlapped to crowded, 3-12 mm wide, surface continuous, smooth, lustrous, becoming cracked towards the center; apical zone rounded; margin broadly crenate to incised, undulated. Maculae distinct, effigurate, laminal, originating effigurate cracks. Cilia black, simple to sometimes furcated or rarely dichotomous, up to $1.5 \mathrm{~mm}$ long, sometimes very thick, 0.04-0.15 mm, abundant. Lacinulae forming arbuscular structures up to $10 \mathrm{~mm}$ high, coralloid-branched, branches flattened to terete, usually ciliate, surface scrobiculate, not sorediate, but with abundant nodules specially in the apices. Pustules, soredia and isidia absent. Medulla white. Undersurface (based in the S isotype): dark brown, lustrous, smooth to papillate or rarely with inconspicuous veins, without cracks; marginal zone yellowish brown, lustrous, 2-12 mm wide, rhizinate, with an attenuated limit, smooth; rhizines black, simple to squarrose, up to $1 \mathrm{~mm}$ long, thin, $0.01-0.05 \mathrm{~mm}$ wide, abundant, evenly distributed.

Apothecia absent. Pycnidia submarginal or rarely laminal, conspicuous, without prominent margin, frequent, ostiole black; conidia not found ( $\sim 30$ pycnidia examined). 


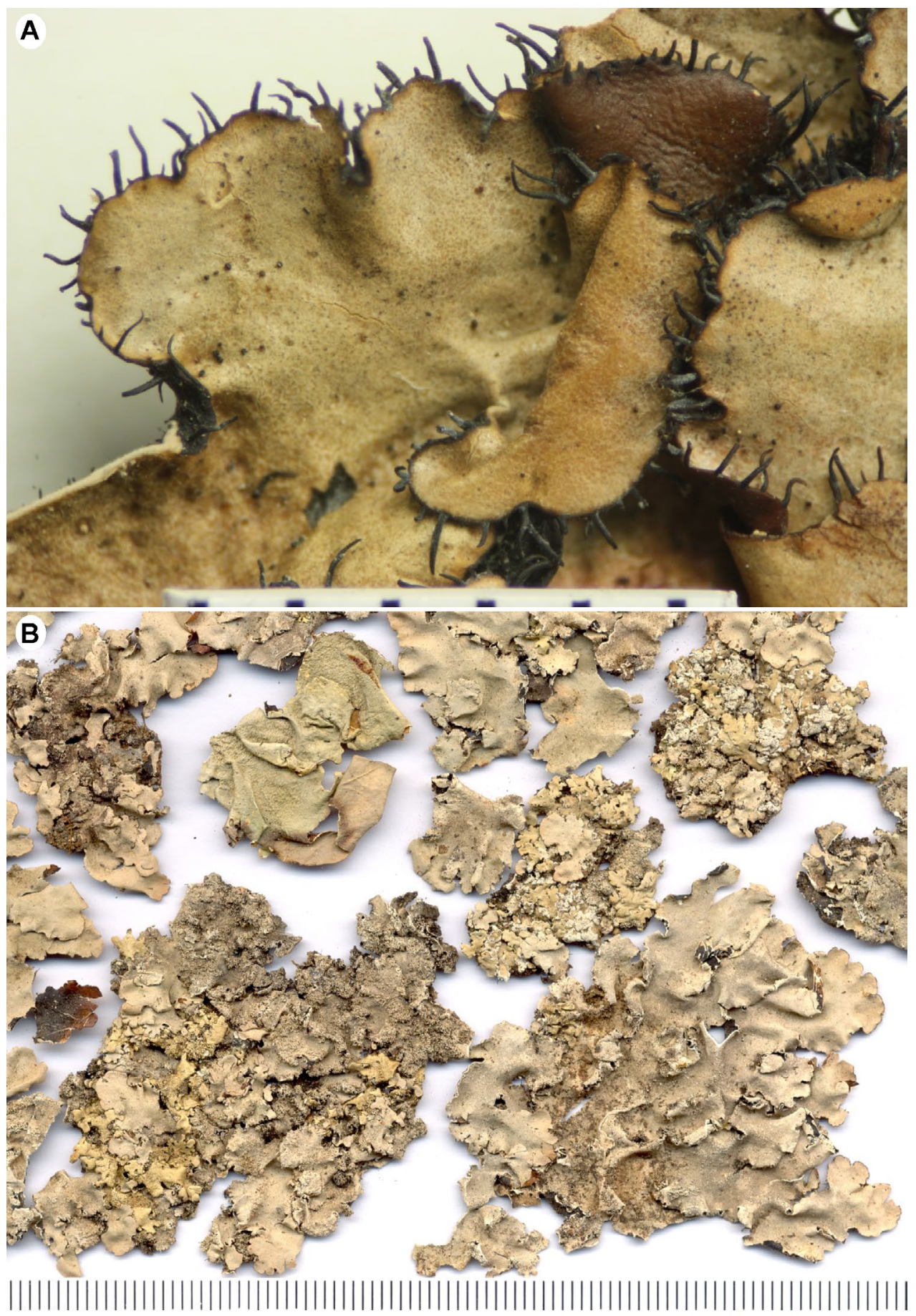

Figure 15. A - holotype of Parmotrema concors (M); B - part of the holotype of Parmotrema concurrens (US). Scales in milimeters.

Chemistry. Atranorin (minor), chloroatranorin (trace), salazinic acid (major), consalazinic acid (minor). Cortex $\mathrm{K}+$ yellow, UV-; medulla $\mathrm{K}+$ yellow $\rightarrow$ blood red, $\mathrm{C}-$, $\mathrm{KC}-, \mathrm{P}+$ strong yellow, $\mathrm{UV}-$.

Remarks. Parmotrema coralliforme is distinguished by the arbuscular structures, which are usually ciliate, and esorediate, the effigurate maculae and the pale brown and rhizinate marginal zone in the undersurface. It can be compared to $P$. ramusculum, which develops eciliate and strongly sorediate arbuscular structures, has punctiform maculae, sparse cilia (abundant in P. coralliforme) and the black naked marginal undersurface. See under
P. ramusculum comments about other species. In Parmotrema coralliforme, the effigurate maculae give rise to distinct cracks, also effigurate. This phenomenon is not common in the species here investigated, since the cracks are usually irregular or reticulate, independent from the type of macula.

The arbuscular structures sometimes break, exposing the white medulla, but true soredia are totally absent.

The isotype (S) agrees well with the holotype. It has more ciliate fascicular structures and, as the holotype, abundant pycnidia; however, no conidia were found. Since the holotype is glued to a card, the isotype was used to describe the underside. 
Distribution. Mexico (Hale 1965; Egan et al. 2016) and Guianas (Sipman 1999).

Parmotrema cristiferum (Taylor) Hale, Phytologia 28(4): 335. 1974.

(Fig. 16B)

Basionym: Parmelia cristifera Taylor, London Journal of Botany 6: 165. 1847.

Type: India. Calcutta: Wallich s.n. (lectotype - FH!).

= Parmelia perforata var. ulophylla Meyen \& Flotow, Novorum Actorum Academiae Caesareae Leopoldino-Carolinae Naturae Curiosum 19, suppl. 1: 218. 1843.

Type: USA Hawaiian Islands: Oahu (lectotype - G!).

= Parmelia hildebrandtii Kremp., Linnaea 41: 139. 1877.

Type: Comoro Islands. Johanna Island: $400 \mathrm{~m}$ alt., an der Rinde von Bäumen (besonders Cycas), an hehten stellen im Walde, Hildebrandt 1866c (holotype - M!; isotypes - BM!, K!).

= Parmelia hildebrandtii f. sorediosa Müll. Arg., Flora 74: 376. 1891.

Type: Comoro Island. Schweinfurth s.n. (lectotype - G!; isotype $-\mathrm{K})$, according to Hale (1965).

$=$ Parmelia mesotropa f. sorediosa Müll. Arg., Flora 74: 377. 1891.

Type: India. Cachar: Keenan (holotype - G!).

Description (based on lectotype). Thallus cream, lobate, apparently loosely adnate, $16 \times 14 \mathrm{~cm}$. Lobes strongly undulated, irregularly branched, laterally overlapped and difficult to distinguish one from the other, $10-18 \mathrm{~mm}$ wide, surface usually cracked; apical zone rounded and crisped; margin strongly sorediate and crispate-undulated. Maculae absent. Soralia whitish, linear continuous or interrupted, sometimes labriform, mainly marginal, although some present in thalline crests, rarely orbicular or capitate, or in small 'columns'; soredia farinose to granular. Lacinulae, cilia, pustules and isidia absent. Medulla white or with the upper part slightly rose (maybe due to eumitrins). Undersurface black, lustrous, strongly papillate, with scars; marginal zone absent or cream under the soralia, opaque, 1-2 mm wide, naked, with a sharp limit, smooth or rugose; rhizines black, simple, up to $1 \mathrm{~mm}$ long, few, distributed in groups.

Apothecia concave, small (up to $2.5 \mathrm{~mm}$ in diameter), substipitate, laminal, margin smooth, sorediate, amphithecium sorediate, disc brown, epruinose, imperforate; ascospores ellipsoid, 24-35 × 12-20 $\mu \mathrm{m}$, episporium 2-3 $\mu \mathrm{m}$. Pycnidia apparently rare (there are several black spots that remember pycnidia, however without any tissue inside); conidia not found ( $\sim 30$ pycnidia studied), but according to Vainio (1909a), the conidia are sublageniform, 5-7 $\mu \mathrm{m}$ long.

Chemistry (TLC in solvent C, HPLC - J.A. Elix, 28.X.1998, label with the holotype in FH). Atranorin (minor), chloroatranorin (trace), salazinic acid (major), consalazinic acid (trace), eumitrin A1 (minor), eumitrin A3 (trace), unknowns (minor/trace). Cortex $\mathrm{K}+$ yellow, $\mathrm{UV}-$; medulla $\mathrm{K}+$ yellow $\rightarrow$ blood red, $\mathrm{C}-, \mathrm{KC}-, \mathrm{P}+$ strong yellow, UV-.

Remarks. Parmotrema cristiferum is characterized by the upper cortex with atranorin, linear marginal soralia, sublageniform conidia and large ascospores (24-35 $\times 12-20 \mu \mathrm{m})$. It is a usually eciliate species, although cilia can rarely be found in some specimens. It can be compared to $P$. stuppeum that also develops marginal soralia, but otherwise has smaller ascospores (12-17 $\times$ 6-9 $\mu \mathrm{m}$, according to Hale 1965). The type is glued by the underside, so only some marginal zones were studied.

Parmelia cristifera was described by Taylor (1847), who cited four specimens, without designating the type. They are, therefore, syntypes: 'Calcutta, Wallich; Mauritius, Dr. Wright; Brazil, Gardner; Demerara, Mr. Parker'. It seems appropriate to analyze each specimen separately (see also Krog \& Swinscow 1981):

i) India, Calcutta, Wallich s.n., was selected as the lectotype of Parmelia cristifera (see Berry 1941; Dodge 1959; Hale 1965);

ii) Brazil, Gardner, is the holotype of Parmelia gardneri C.W. Dodge (Dodge 1959);

iii) Mauritius, Dr. Wight (not 'Wright' as cited in the protologue) represents one syntype of Parmelia cristifera. And, at the same time, it is one specimen cited in the protologue of Parmelia sieberi (Dodge 1959);

iv) Demerara (Guyana), Mr. Parker, is not Parmelia cristifera, since salazinic acid is lacking (medulla $\mathrm{K}-$ ). There is a label from Krog pointing out the existence of only fatty acids (TLC), and another one from Hale (May 8, 1959) determining this species as Parmelia sanctae-crucis Vain. Krog \& Swinscow (1981) asserted that it belongs to Parmelia praesorediosa Nyl. Presently, both species are synonyms of Parmotrema praesorediosum (Nyl.) Hale.

Seemingly, the first author to choose the specimen Wallich s.n. (FH!) as lectotype was Berry (1941). He left a label (signed E.C.B.) in 1938 pointing this out. Nevertheless, the ascospores measurements $(6-8 \times$ 2-4 $\mu \mathrm{m})$ published in 1941 are certainly a typographical error, since such small ascospores are not known in Parmotrema.

Lindsay (1866) made comments about the Gardner specimen from Brazil, i.e., Parmotrema gardneri. Müller Argoviensis (1888) asserted that the Calcutta specimen was sterile, while the Brazilian one was fertile. However, the two types (FH!) are clearly fertile. Merrill (1909) reported Parmelia cristifera to the United States and Hawaii, distinguishing it from P. latissima.

Lynge (1914), when describing Malme's collections from Mato Grosso, Brazil, found ascospores with 22-27 $\times 10.5-14 \mu \mathrm{m}$, with an episporium $2 \mu \mathrm{m}$ wide. These are a little smaller than that published by Hale (1965): 26-35 $\times 13-18 \mu \mathrm{m}$, episporium 3-4 $\mu \mathrm{m}$.

Lamb (1963) cited one variety and two forms of Parmelia cristifera: P. cristifera var. abissinica Cengia Sambo is actually Flavopunctelia flaventior (Hale 1980; Hale \& DePriest 1999). Parmelia cristifera f. pallida is a synonym of Parmotrema perlatum (Hale 1965), and finally $P$. cristifera f. cinerata corresponds to Parmotrema cristiferum (Hale 1965).

This is one of the cases where Hale (1965) choose to illustrate additional specimens examined instead of the type material, one from Mexico (Hale 20073, Fig. 5) and the other from Formosa (Taiwan) (Ogata s.n., Fig. 16). 
These were not asked for on loan. Even so, we prefer to choose the lectotype from $\mathrm{FH}$ to illustrate here.

We failed to find conidia in the lectotype, and so we are relying on Vainio (1909a), who observed that 'Secundum specimen no. 35399 in herb. Nyl. var. cristifera apotheciis instructa est cupuliformibus, breviter pedicellatis, imperforatis, disco testaceo rufo, sporis long. 0,026-0,032 mm., crassit. 0,015-0,018 mm, pycnoconidiis sublageniformibus, long. 0,005-0,007 mm., crass. $0,001 \mathrm{~mm}$ (secund. annot. Nylanderi in specimine a Jardin lecto e loco incerto)'.
It is difficult to know the substrate of the syntypes. The protologue (Taylor 1847) gives no indication.

We studied two specimens of Parmelia perforata var. ulophylla from G. One is sorediate ('A'), sterile, with strongly crisped lobes and occasional cilia (up to $0.5 \mathrm{~mm}$ long) in one part of the thallus. Therefore, it clearly matches with Parmotrema cristiferum, when compared with the lectotype (FH!). The occasional cilia were realized by Meyen \& Flotow (1843).

The second thallus ('B') has two imperforate apothecia, reticulate maculae and cracks, being a Parmotrema

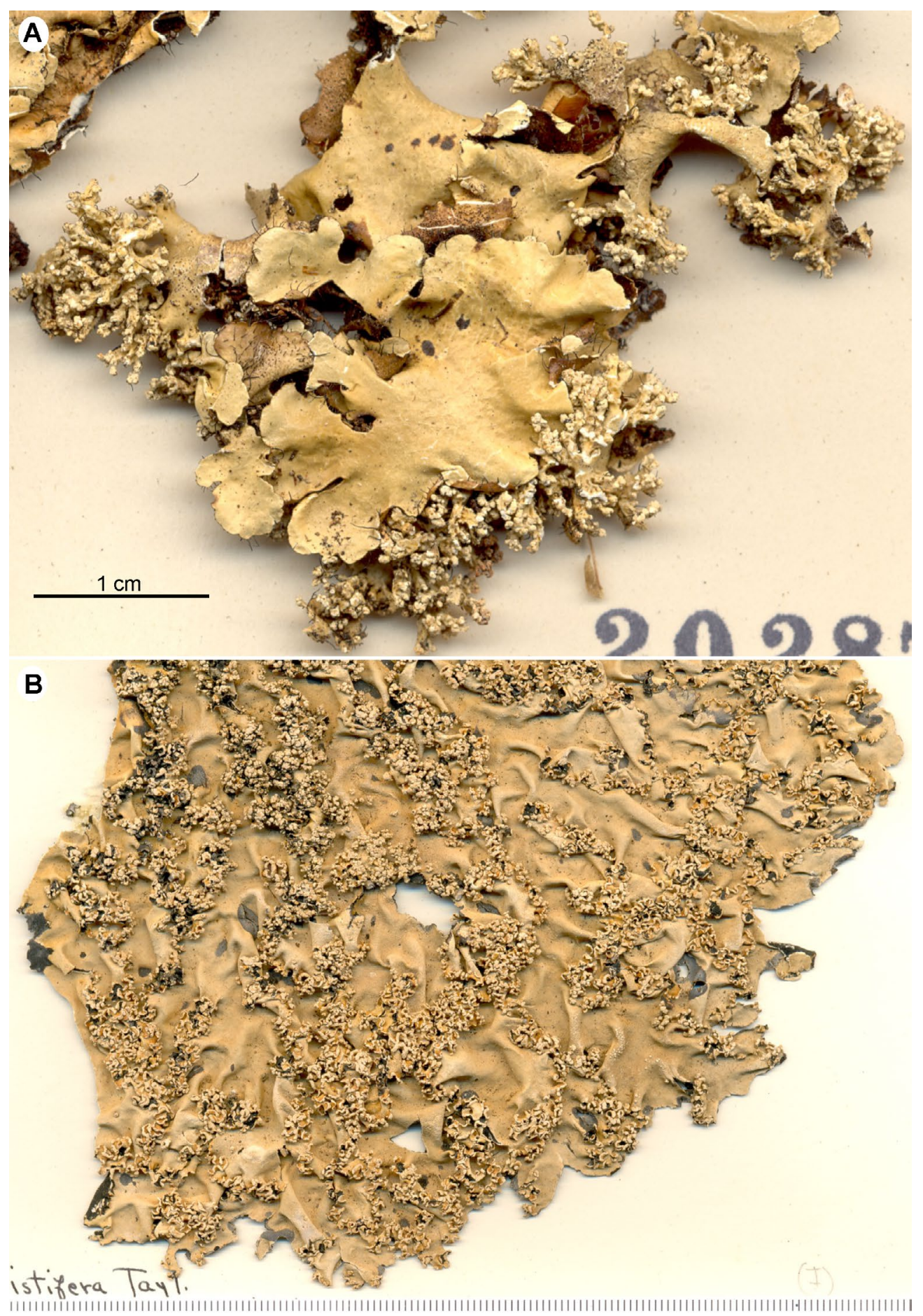

Figure 16. A - part of the holotype of Parmotrema coralliforme (US); B - lectotype of Parmotrema cristiferum (FH). Scales in milimeters, except as indicated. 
that would be classified in the former genus Rimelia. There is an anonymous annotation of the ascospores (14$17 \times 8-11 \mu \mathrm{m})$, confirming they are very different from those of $P$. cristiferum. The actual status of this specimen remained unclear and was not further investigated here since it is in a poor condition.

We performed chemical studies on both thalli and found the same results: atranorin (minor), chloroatranorin (trace), salazinic acid (major), consalazinic acid (minor), and an unknown fatty acid Rfc 20 (minor).

Krempelhuber (1877) described P. hildebrandtii with ascospores 11-15 × 11-12 $\mu \mathrm{m}$. These dimensions differ strongly from those accepted for Parmotrema cristiferum. Krog \& Swinscow (1981) already wondered about the identity of this species and pointed out it could be compared to $P$. stuppeum on the ascospore size basis.

Hale (1965) stated that there were isotypes in BM and $\mathrm{K}$, but did not indicate the location of the holotype, as well as Winnem (1975). Actually, the holotype of $P$. hildebrandtii is located in $\mathrm{M}$, as we discovered after consultation with the curator, Dr. Andreas Beck. It is a well-developed specimen, composed of three pieces, two of them certainly part of the same thallus, and the third part with several apothecia (as indicated by Krempelhuber 1877). Seven attempts to find ascospores were made in the more mature apothecia, but without success. Conidia, however, are sublageniform, 5-7 $\times \sim 1 \mu \mathrm{m}$, matching the conidia of $P$. cristiferum. In the exsiccate, Krempelhuber left a drawing of the asci with ascospores. The sizes given are $11-15 \times 11-12 \mu \mathrm{m}$.

In the apothecium from the $\mathrm{K}$ specimen, the hymenium is strongly guttulate and little developed since only few ascospores were found, some clearly immature. They measure 20-29 × 10-14 $\mu \mathrm{m}$, the episporium 2-2.5 $\mu \mathrm{m}$, close to the accepted dimensions for $P$. cristiferum.

Unfortunately, pycnidia are absent in the K specimen. The specimen from BM has submarginal pycnidia with sublageniform conidia $6.5-8.5 \times \sim 1 \mu \mathrm{m}$, agreeing with the accepted Parmotrema cristiferum and equal to that found in the holotype of $P$. hildebrandtii.

In conclusion, probably Krempelhuber found immature ascospores, and therefore Parmelia hildebrandtii is a synonym of Parmotrema cristiferum.

With the BM specimen, there is an annotation made by B. Winnem, dated 22.II.1974, informing that atranorin and salazinic acid were found (TLC).

Hale (1965) referred Parmelia hildebrandtii f. sorediosa with one lectotype in $\mathrm{G}$ and one isotype in $\mathrm{K}$. The curator of $\mathrm{K}$ Herbarium informed us that some specimens were not sent, because they could have been deposited at the Natural History Museum.

The specimen received from $G$ consists of a small, sorediate thallus with sublageniform conidia, 5-8 $\times \sim 1 \mu \mathrm{m}$. The chemical study revealed atranorin (minor), chloroatranorin (trace), salazinic acid (major), and consalazinic acid (minor). Although the eumitrins are lacking, it is morphologically similar to $P$. cristiferum, and thus we agree with the synonymization proposed by Hale (1965). However, the K specimen could provide additional evidence, e.g. the size of ascospores, which are quite large in P. cristiferum.
Hale (1965) asserted that the holotype of Parmelia mesotropa $\mathrm{f}$. sorediosa would be deposited in $\mathrm{K}$, while the isotype in G. We have received two specimens from these herbaria. The specimen in $\mathrm{G}$ is labeled as holotype (contrary to the information given in Hale 1965). Morphologically and chemically, it agrees well with the lectotype of $P$. cristiferum, and so it is accepted here as a synonym. The chemistry was reported in a label by Elix (3.X.1998), through TLC in solvent C and HPLC: atranorin (major), chloroatranorin (trace), salazinic acid (major), consalazinic acid (minor), eumitrin A1 (trace), eumitrin A3 (trace).

The specimen from $\mathrm{K}$ available for the study has marginal soredia and a naked lower margin, clearly a Parmotrema, without cilia. The cortex is $\mathrm{K}+$ yellow, $\mathrm{UV}-$, the medulla $\mathrm{K}-, \mathrm{C}+$ red, $\mathrm{KC}+$ red, $\mathrm{P}-$. Since it has lecanoric acid, it probably belongs to Parmotrema austrosinense. The conidia are filiform, $9-13 \times \sim 1 \mu \mathrm{m}$. There is no annotation from Hale, so maybe he did not see this specimen. There is also no indication whether this is a type.

Therefore, for the moment, we are accepting the $G$ specimen as the holotype.

Distribution. North America (Merrill 1909; Berry 1941; Hale 1965; Brodo et al. 2001; Egan et al. 2016), Central America (Hue 1899; Hale 1965), South America (Hue 1899; Hale 1965), Africa (Hue 1899; Hale 1965; Krog \& Swinscow 1981), Asia (Taylor 1847; Vainio 1909a; Hue 1899; Hale 1965; Chen et al. 2005; Divakar \& Upreti 2005) and Oceania (Merrill 1909; Hue 1899; Hale 1965; Elix 1994; Louwhoff \& Elix 1998). In South America it is known from Venezuela, British Guiana, Suriname, Colombia (Hale 1965), Ecuador, Galápagos (Bungartz \& Spielmann 2019), Peru (Hale 1965), Bolivia (Kukwa et al. 2012) and Brazil (Hale 1965). In Brazil, it was recorded from Mato Grosso (Lynge 1914), Minas Gerais (Zahlbruckner 1905), Paraná (Donha 2005) and São Paulo (Zahlbruckner 1909; Hale 1965; Marcelli \& Benatti 2010).

Parmotrema cristobaliae (Ferraro \& Elix) Blanco, Crespo, Divakar, Elix \& Lumbsch, Mycologia 97(1): 157. 2005

(Fig. 17A)

Basionym: Rimeliella cristobaliae Ferraro \& Elix, Mycotaxon 49: 406. 1993.

Type: Argentina. Corrientes: Depto. Ituzaingó, Rincón Ombú Chico, L.I. Ferraro, S. Tressen, A. Schinini \& M. Gonzales 687, 25.IV.1975 (holotype - CTES!).

$\equiv$ Canomaculina cristobaliae (Ferraro \& Elix) Elix, Mycotaxon 65: 477. 1997.

Description (based on holotype). Thallus brownish (herbarium), lobate, loosely adnate, corticicolous, $10.5 \mathrm{~cm}$ broad. Lobes irregularly branched, \pm crowded, $3-10 \mathrm{~mm}$ wide, surface continuous to cracked, smooth to notched, lustrous, becoming reticulate cracked towards the center; apical zone rounded to abundantly lacinulate; margin deeply crenate to sublacinulate, undulated. Maculae distinct, effigurate, although sometimes assuming a pseudoreticulate aspect, laminal, originating cracks or not. Cilia black, simple to rarely squarrose or furcated, usually short, 
up to $0.7 \mathrm{~mm}$ long, $0.02-0.04 \mathrm{~mm}$ wide, abundant. Lacinulae irregularly branched to subdichotomous, present in the whole thallus, plane to slightly convex, apex rounded, truncate or acute, 2-7 × 1-6 mm. Isidia, soredia and pustules absent. Medulla white. Undersurface black, lustrous, smooth or papillate, with cracks; marginal zone brown to dark brown, lustrous, 1-3 mm wide, rhizinate and papillate, with an attenuated limit; rhizines black, dimorphic, short rhizines simple, up to $0.5 \mathrm{~mm}$ long, $0.01-0.04 \mathrm{~mm}$ wide, abundant, evenly distribute, long rhizines usually subsquarrose to irregularly branched, up to $2 \mathrm{~mm}$ long, 0.04-0.06 mm wide, frequent, distributed in groups.
Apothecia \pm plane, $6-10 \mathrm{~mm}$ in diameter, stipitate, margin smooth to slightly incise, undulated, amphithecium maculate, rugose, disc brown, epruinose, perforate; ascospores ellipsoid, 12-14 × 7.5-9 $\mu \mathrm{m}$, episporium $1-1.5 \mu \mathrm{m}$. Pycnidia laminal or more commonly submarginal, conspicuous, with or without prominent margin, abundant, ostiole black; conidia filiform, 9-14 $\times \sim 1 \mu \mathrm{m}$.

Chemistry. Atranorin, chloroatranorin, salazinic acid (major), norlobaridone (major), consalazinic acid (minor/ trace), loxodin (minor/trace) (Ferraro \& Elix 1993).
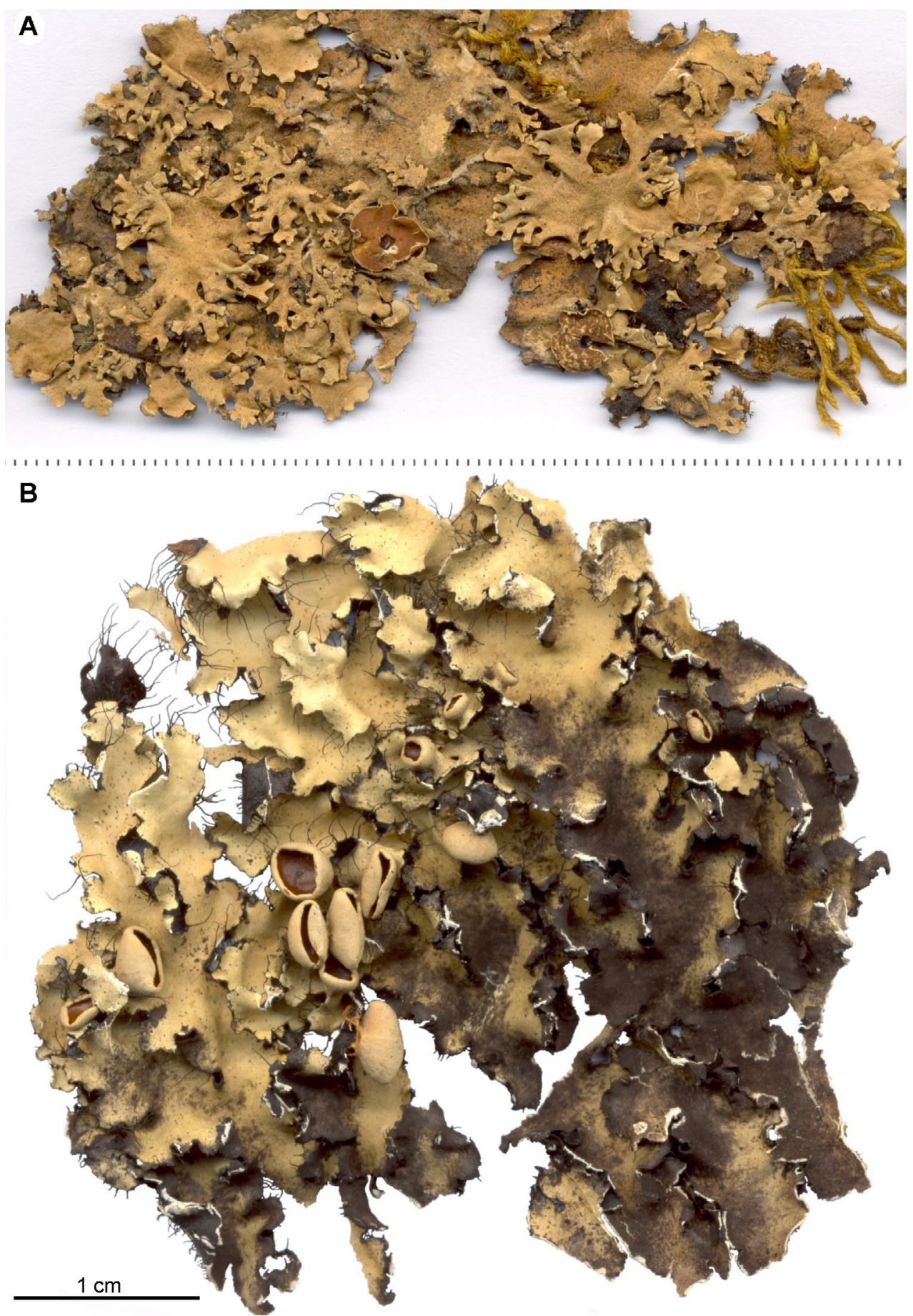

Figure 17. A - holotype of Parmotrema cristobaliae (CTES); B - holotype of Parmotrema delicatulum (TUR-V). Scales in milimeters, except as indicated. 
Cortex $\mathrm{K}+$ yellow, UV-; medulla $\mathrm{K}+$ yellow $\rightarrow$ blood red, $\mathrm{C}-, \mathrm{KC}-, \mathrm{P}+$ strong yellow, $\mathrm{UV}-$.

Remarks. Parmotrema cristobaliae is distinguished by the strongly lacinulate thallus without vegetative propagules, the effigurate maculae, dimorphic rhizines and the production of salazinic acid and norlobaridone. Pseudoreticulate maculae are also present.

Ribeiro (1998) reported P. cristobaliae to Minas Gerais, Brazil. However, the study of the specimen Marcelli \& Yano 23972 (SP) shows that it belongs to another taxon, probably $P$. subcaperatum. In this way, P. cristobaliae remains known only to Argentina and Bolivia.

The holotype from CTES is a well-developed specimen, fertile and fully lacinulate. Some features of the lobes are difficult to evaluate since the thallus is, for the most part, covered by the lacinulae.

The correct orthography of the specific epithet is cristobaliae instead of cristobalii, because the honored person is a female, as pointed out by Ribeiro (1998) and Hale \& DePriest (1999). It follows the Article 60.8 of the Shenzen Code.

Distribution. South America, where it was recorded from Bolivia andArgentina (Ferraro \& Elix 1993).

Parmotrema delicatulum (Vain.) Hale, Phytologia 28(4): 335. 1974.

(Fig. 17B)

Basionym: Parmelia delicatula Vain., Acta Societatis pro Fauna et Flora Fennica 7(1): 35. 1890.

Type: Brazil. Minas Gerais: Catas Altas, Caraça [nowadays Parque Natural do Caraça], 1885, Vainio (holotype - TUR-V! isotypes - BM!, FH!, M, UPS).

$=$ Parmelia radians Lynge, Arkiv för Botanik 13(13): 85 . 1914.

Type: Brazil. Minas Gerais: Municipality of São João d'el Rey [del Rei], G.O.A. Malme 203 (holotype - S!; isotype-MO).

= Parmelia subcaperata f. ciliata Zahlbr., Bulletin de L'Herbier Boissier Ser. 2, 4: 135. 1904.

Type: Brazil. Minas Gerais: Morro de São Sebastião, Damazio 940 (holotype - W; isotype - G!).

Description (based on holotype). Thallus yellowish, blackening toward the center, sublaciniate, loosely adnate, saxicolous, $4.5-5 \mathrm{~cm}$ broad. Sublaciniae irregularly branched, contiguous with laterally overlapped or crowded margins, 1-3.5 mm wide, surface continuous, smooth, lustrous, becoming cracked in the center; apical zone rounded, or subtruncate; margin crenate to sublacinulate, undulated. Cilia black, simple or sometimes furcated, $1.5-2.8 \times 0.03-0.1 \mathrm{~mm}$, abundant in the young regions. Lacinulae, maculae, pustules, soralia and isidia absent. Medulla white. Undersurface black, lustrous, smooth, papillate or slightly rugose, with numerous scars; marginal zone usually absent, i.e., black, or rarely dark brown, lustrous, 1-1.2 mm wide, naked, smooth or with few papillae; rhizines black, simple or rarely furcated next to the apex, $0.2-1.5 \times 0.01-0.05 \mathrm{~mm}$, frequent, irregularly distributed.

Apothecia cupuliform, $1.3-4.3 \mathrm{~mm}$ in diameter, substipitate, submarginal, margin smooth or slightly crenate with small incisions, amphithecium smooth, pruinose, maculate, eciliate, disc dark brown, epruinose, imperforate; ascospores ellipsoid, 11-12.5 × 7.5-9 $\mu \mathrm{m}$, episporium $0.5-1 \mu \mathrm{m}$. Pycnidia submarginal, rarely laminal, conspicuous, with or without prominent margin, abundant, ostiole black; conidia short-filiform, straight or slightly curved, 7.5-9 $\times \sim 0.5 \mu \mathrm{m}$.

Chemistry (TLC in solvent C, HPLC - J.A. Elix, 07.V.1996, label with the holotype in TUR-V). Usnic acid (minor), salazinic acid (major), consalazinic acid (minor), gyrophoric acid (minor), hypoconstictic acid (minor), lecanoric acid (trace). Cortex $\mathrm{K}+$ yellow, $\mathrm{UV}$-; medulla $\mathrm{K}+$ yellow $\rightarrow$ blood red, $\mathrm{C}-, \mathrm{KC}-, \mathrm{P}+$ strong yellow, UV-.

Remarks. Parmotrema delicatulum can be recognized by the yellowish thallus (usnic acid) composed of narrow sublaciniae (1-3.5 mm wide) and developing long cilia. The closest species is $P$. magnum, distinguished by the wider lobes (5-15 mm), shorter cilia (up to $1.5 \mathrm{~mm}$ ) and the abundance of medullar gyrophoric acid (C+ rose). Additionally, the amphithecia are smooth in P. delicatulum and strongly rugose in P. magnum. However, examination of fresh specimens and molecular studies could bring new insight into these species. We can preliminarily hypothesize that $P$. delicatulum s.str. is more or less restricted in distribution, growing only in the mountains of Minas Gerais and Rio de Janeiro, while P. magnum can be found in these same places and extends to the south, reaching Rio Grande do Sul and Uruguay.

The holotype of $P$. delicatulum has the upper surface blackening towards the center, but it seems derived from the herbarium preservation or the age of the specimen.

The BM isotype agrees well with the features of the holotype, but only immature ascospores were found. The isotype from $\mathrm{M}$ was not found by the curator (A. Beck, pers. comm.). According to Hale (1965), there is an isotype of Parmelia delicatula in UPS, however, this specimen was not available for the study, and only a picture could be seen.

The holotype of Parmelia radians has a strongly pruinose upper surface, cilia more commonly furcated and a more plane and adnate thallus than Parmotrema delicatulum. Its chemical study (TLC in solvent C, HPLC J.A. Elix, 10.V.1996) revealed the presence of usnic acid (minor), salazinic acid (major), consalazinic acid (minor) and hypoconstictic acid (trace). This profile makes it also more similar to $P$. delicatulum than to $P$. magnum, which contains gyrophoric acid (major) and does not produce hypoconstictic acid. Its conidia are short-filiform, 6-9 $\times 1 \mu \mathrm{m}$, matching both $P$. delicatulum and $P$. magnum. Unfortunately, apothecia are not known in $P$. radians, so no additional features could be compared and we are accepting this taxon as a synonym of $P$. delicatulum.

According to Hale (1965), the holotype of Parmelia subcaperata f. ciliata is stored in $\mathrm{W}$, but it has not been so far located there (Igersheim, pers. comm.). The isotype preserved in $\mathrm{G}$ presents the same morphology and chemistry as the holotype of $P$. delicatulum, being clearly a synonym. It has conidia slightly shorter $(5-7.5 \mu \mathrm{m})$ and ascospores slightly longer $(12.5-13.5 \mu \mathrm{m})$ when compared with the holotype of $P$. delicatulum. 
Distribution. South America, where it is reported from Venezuela (Feuerer 2008), Brazil (Zahlbruckner 1909, 1930a; Hale 1965; Fleig 1997), Paraguay (Osorio 1970), Uruguay (Hale, 1965) and Argentina (Osorio 1981). In Brazil, it is known from Mato Grosso do Sul (Fleig \& Riquelme 1991), Minas Gerais, Paraná, Rio de Janeiro (Hale 1965) and Rio Grande do Sul (Spielmann 2006).

Parmotrema despectum Kurok., Bulletin of the National Science Museum Tokyo, Ser. B, 27(1): 5. 2001.

(Fig. 18A)

Type: USA Virginia: King George Co., Along Rt. 623 near Rt. 301, C.F. Reed 59408 (holotype - US!).

Description (based on holotype). Thallus brownish in the central part and usually becoming brownish-red toward the lobe apices (herbarium), lobate, more or less coriaceous, apparently loosely adnate, corticicolous, about $10 \mathrm{~cm}$ broad. Lobes irregularly branched, laterally overlapped, 7-13 mm wide, surface usually more or less scrobiculate, sublustrous, becoming cracked towards the center; apical zone roughly rounded; margin sublacinulate or sometimes irregularly erose-incised, undulated. Maculae weak to more frequently distinct, effigurate to extensive (hypermaculate). Cilia black, simple, 0.5-2.2 × 0.05-0.1 mm, frequent. Subacinules simple or sometimes dichotomously branched, present in the whole thallus, plane, apex usually acute, $0.3-3 \times 0.2-1.5 \mathrm{~mm}$. Pustules, soredia and isidia absent. Medulla white. Undersurface black, lustrous, rugose to smooth in some areas, sometimes conspicuously veined, with cracks; marginal zone absent reddish brown, lustrous, $0.5-4 \mathrm{~mm}$ wide, naked or less frequently rhizinate, with an attenuated limit, smooth to rugose or veined, sometimes papillate; rhizines black, simple to
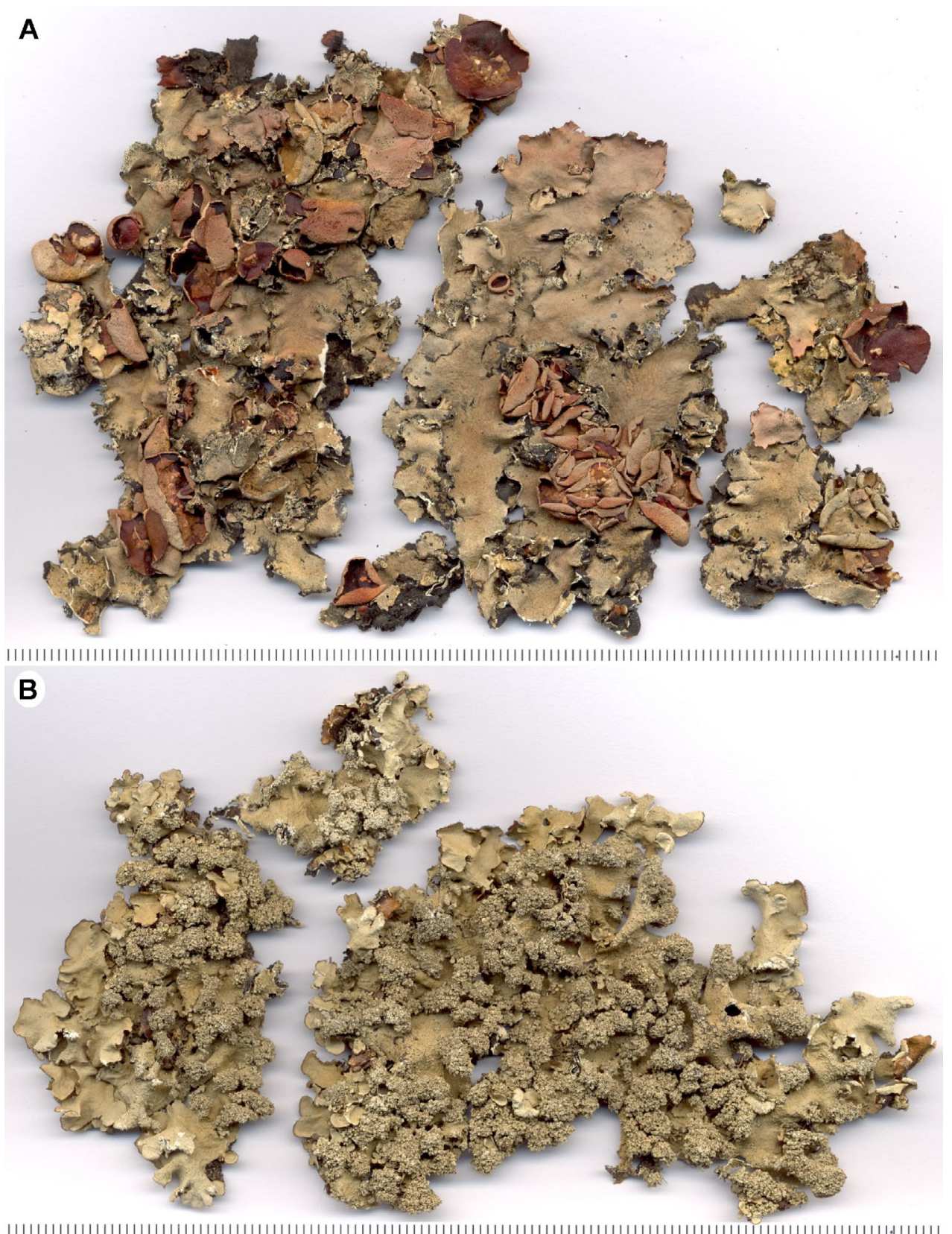

Figure 18. A - holotype of Parmotrema despectum (US); B - isotype of Parmotrema elixii (CANB). Scales in milimeters. 
irregularly branched, $0.4-2.1 \times 0.05-0.1(-0.15) \mathrm{mm}$, abundant, distributed mainly in groups.

Apothecia usually cupuliform (although the specimen was visibly pressed down) or urceolate, 5-15 $\mathrm{mm}$ in diameter, stipitate, apparently submarginal, margin usually curled in, smooth to crenate, less frequently incised and rarely dentate eciliate, amphithecium maculate, disc dark brown, epruinose, perforated in some apothecia only; ascospores ellipsoid to oval, 13-16.5 $\mu \mathrm{m} \times 6.5-9 \mu \mathrm{m}$, episporium $\sim 1 \mu \mathrm{m}$. Pycnidia submarginal, conspicuous, with or without prominent margin, abundant, ostiole black; conidia short-filiform, 7.5-10 $\times \sim 1 \mu \mathrm{m}$.

Chemistry. Atranorin (minor), chloroatranorin (trace), salazinic acid (major), consalazinic acid (minor). Cortex $\mathrm{K}+$ yellow, UV-; medulla $\mathrm{K}+$ yellow $\rightarrow$ blood red, $\mathrm{C}-$, $\mathrm{KC}-, \mathrm{P}+$ strong yellow, $\mathrm{UV}-$.

Remarks. Parmotrema despectum is characterized by weak maculation of the upper cortex (although sometimes with more or less distinct or extensive maculae), the presence of only sublacinulae and the quite short cilia (when compared with the long ciliate species). Parmotrema eurysacum can be distinguished by the conspicuous lacinulae, the wider lobes, widely perforated apothecia and the mainly smooth undersurface (almost constantly rugose in $P$. despectum). For more comparisons, see comments under this species and under Parmotrema reparatum.

Distribution. USA and Mexico (Kurokawa 2001; Egan et al. 2016).

Parmotrema elixii Spielmann \& Marcelli, nom. nov.

(Fig. 18B)

MycoBank MB 838182

Basionym: Rimelia pustulata Elix \& Bawingan, Mycotaxon 81: 252. 2002.

Type: Australia. Western Australia: Mt Clarence, Albany, $35^{\circ} 02^{\prime} \mathrm{S} .117^{\circ} 54^{\prime} \mathrm{W}, 230 \mathrm{~m}$ alt., dry sclerophyll forest with large granite outcrops, on shaded granite ledges, 15.IX.1994, J.A. Elix, H.T. Lumbsch \& H. Streimann 41377 (holotype - CANB; isotype - CANB!, HO, PERTH!).

$\equiv$ Parmotrema pustulatum (Elix \& Bawingan) O. Blanco, A. Crespo, Divakar, Elix \& Lumbsch, Mycologia 97(1): 157, 2005, nom. illeg. (later homonym), non Parmotrema pustulatum Louwhoff \& Elix, Mycotaxon 75: 199. 2000.

Description (based on isotype from CANB). Thallus brownish (herbarium), lobate, loosely adnate, saxicolous, 6-9 cm broad. Lobes irregularly branched, \pm crowded, 2-10 mm wide, surface continuous or cracked, smooth or slightly rugose, lustrous, becoming rugose and reticulate cracked towards the center, in some areas the areolae flaking off; apical zone rounded; margin smooth to crenate or sublacinulate, undulated. Maculae distinct, reticulate, laminal, originating cracks. Cilia black, simple, short, up to $0.5 \mathrm{~mm}$ long, $0.02-0.05 \mathrm{~mm}$ wide, frequent. Lobules spatulate, frequently formed from the pustules, $0.5-2 \times 0.4-1.5 \mathrm{~mm}$. Pustules \pm capitate, usually forming dense aggregates, laminal and submarginal, originating soredia-like structures. Lacinulae, isidia and true soredia absent. Medulla white. Undersurface black, lustrous, usually papillate or rugose, with cracks; marginal zone dark brown, lustrous, 1-3 mm wide, rhizinate, with an attenuated limit, papillate; rhizines black, simple to branched, up to $1.5 \mathrm{~mm}$ long, $0.02-0.1 \mathrm{~mm}$ wide, frequent, irregularly distributed.

Apothecia unknown. Pycnidia immature, submarginal, inconspicuous, without prominent margin, rare, ostiole black; conidia not found (10 pycnidia examined).

Chemistry (TLC in solvent C, HPLC - J.A. Elix, 07.XI.2002, label with the isotype in CANB). Atranorin (minor), chloroatranorin (minor), salazinic acid (major), consalazinic acid (minor). Cortex $\mathrm{K}+$ yellow, UV-; medulla $\mathrm{K}+$ yellow $\rightarrow$ blood red, $\mathrm{C}-, \mathrm{KC}-, \mathrm{P}+$ strong yellow, UV-.

Etymology. Dedicated to J.A. Elix, one of the giants in Lichenology.

Remarks. Parmotrema elixii is distinguished by the reticulate maculae, the medulla with salazinic acid, short cilia (up to $0.5 \mathrm{~mm}$ long) and principally by the production of pustules, usually forming dense aggregates. It can be compared to $P$. granulare that also has reticulate maculae, but otherwise distinct lacinulae with individualized pustules (i.e., not forming aggregates), and $P$. anchietanum Marcelli, Benatti \& Elix (see Benatti et al. 2008), characterized by the narrow (1-3 $\mathrm{mm})$ and lacinulate lobes.

The new name $P$. elixii is here being proposed to the species earlier known as Rimelia pustulata Elix \& Bawingan (Elix et al. 2002). That species is clearly different from Parmotrema pustulatum (Louwhoff \& Elix 2000), which is emaculate and without salazinic acid. When Blanco et al. (2005) synonymized the genus Rimelia under Parmotrema, they proposed the combination 'Parmotrema pustulatum (Elix \& Bawingan) O. Blanco, A. Crespo, Divakar, Elix \& Lumbsch' to Rimelia pustulata, so creating a later homonym and, therefore, the necessity of a new name.

We did not have access to the holotype, however CANB sent an isotype. It is well-developed and all features could be described. In the isotype from PERTH, however, the underside was not studied, since the lichen is glued to a paper card. Even so, it agrees well with the CANB isotype.

Distribution. Philippines and Australia (Elix et al. 2002).

Parmotrema enteroxanthum Hale, Mycotaxon 5(2): 434. 1977.

(Fig. 19A)

Type: Venezuela. Merida: La Carbonera, sector El Pedregal, on rocks in open pasture, $2100 \mathrm{~m}$ alt., 19-III-1975, M.E. Hale \& M. Lopez Figueiras 44177 (holotype - US; isotypes - MERF, UPS!).

Description (based on isotype from UPS). Thallus whitish-grey, lobate, loosely adnate, saxicolous, $9 \mathrm{~cm}$ broad; lobes irregularly branched, crowded, $0.5-1.3 \mathrm{~mm}$ wide, surface continuous to irregularly cracked, sometimes flaking off some parts of the upper cortex, smooth, lustrous to opaque, becoming cracked in the center; apical 

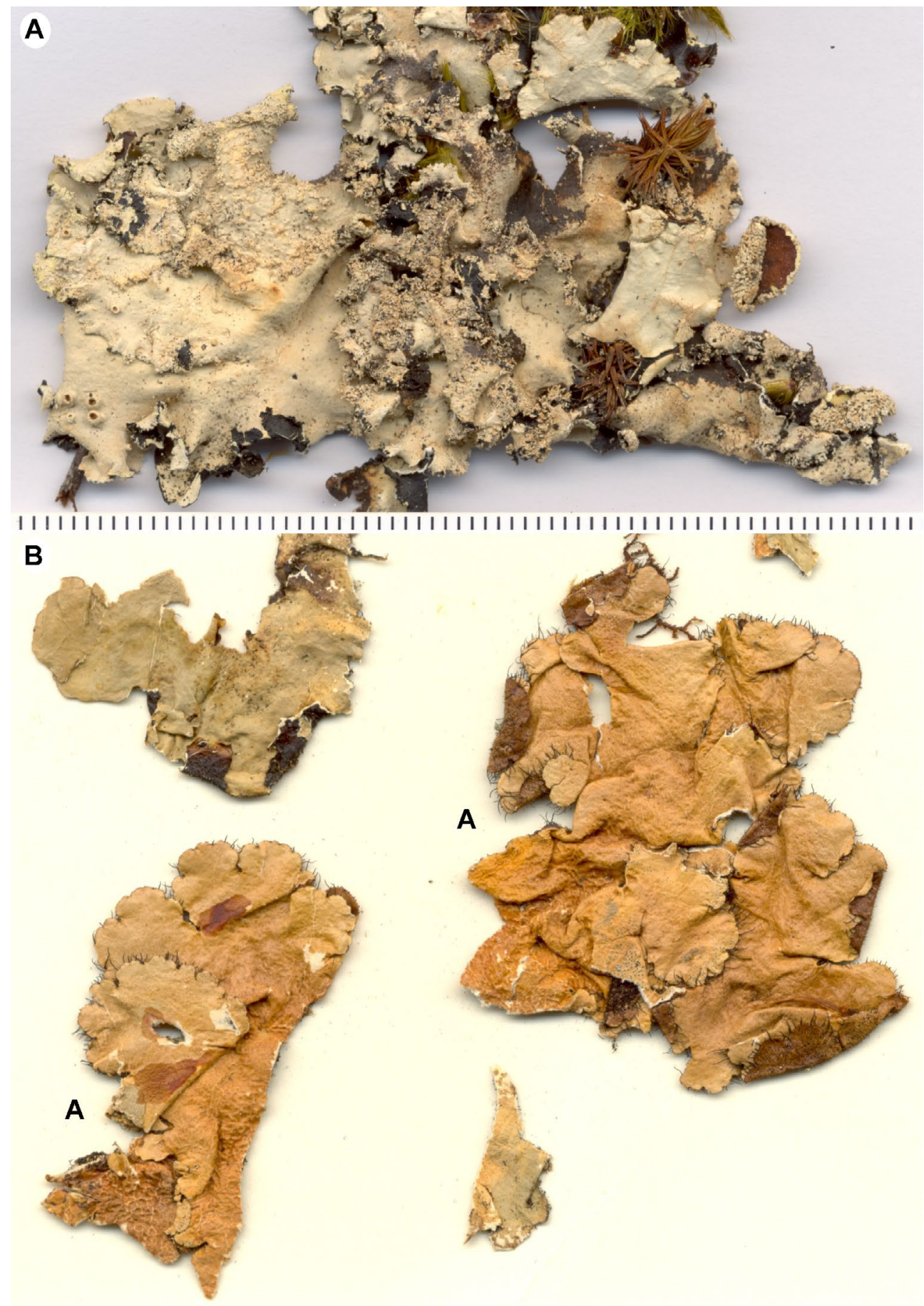

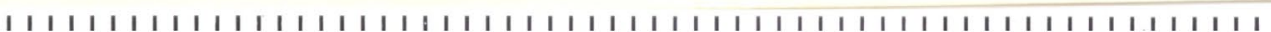

Figure 19. A - isotype of Parmotrema enteroxanthum (UPS); B - lectotype of Parmotrema erubescens (BM). Scales in milimeters.

zone rounded; margin smooth or irregular, undulated. Maculae and cilia absent. True isidia absent. Dactyloid structures concolor to the thallus, simple to coralloid, up to $1 \mathrm{~mm}$ high, usually thick and inflated, $0.2-0.8 \mathrm{~mm}$ wide, erect, firm or friable, then leaving a yellow tuft of medulla, apex eciliate Pustules laminal, extensive, giving raise to schizidioid or dactyloid structures. Lacinulae and soredia absent. Medulla entirely yellow or more frequently only the under portion. Undersurface black, lustrous, smooth, slightly rugose or papillate, rarely veined, strongly cracked; marginal zone absent (black) or pale to dark brown, lustrous, $1.5-4 \mathrm{~mm}$ wide, naked, with an attenuated to sharp limit, smooth; rhizines black, simple or rarely branched, up to $1.5 \mathrm{~mm}$ long, $0.01-0.1 \mathrm{~mm}$ wide, frequent, distributed in groups.

Apothecia cupuliform, 1-7.5 $\mathrm{mm}$ in diameter, stipitate, laminal to submarginal, margin crenate to incised, usually involute, amphithecium smooth to strongly pustulate, emaculate or with faint maculae, disc brown, epruinose, imperforate; ascospores ellipsoid to slightly reniform 30-35 × 14-19 $\mu \mathrm{m}$, episporium 2.5-4.5 $\mu \mathrm{m}$. Pycnidia mainly submarginal, conspicuous, without prominent margin, abundant, ostiole black; conidia sublageniform, 5-6.5 $\times 1 \mu \mathrm{m}$. 
Chemistry atranorin (minor), chloroatranorin (trace), salazinic acid (major), consalazinic acid (minor). Cortex $\mathrm{K}+$ yellow, UV-; medulla $\mathrm{K}+$ yellow $\rightarrow$ blood red, $\mathrm{C}-$, $\mathrm{KC}-, \mathrm{P}+$ strong yellow, $\mathrm{UV}-$.

Remarks. Parmotrema enteroxanthum can be recognized by the yellow medulla (at least the inferior portion), swollen and dactyloid isidia, sublageniform conidia and large ascospores (30-35 $\mu \mathrm{m}$ long).

The holotype collection from US and the isotype from MERF were not available for the study. The isotype in UPS is composed of two parts that, presumably, are part of one single thallus. However, it is interesting to note that one part has well-developed isidia, while the other does not. In the other features, however, both parts are identical, including the yellow medulla and large ascospores.

As far as we know, there are no other species of Parmotrema with salazinic acid and yellow medulla.

Distribution. Venezuela (Hale 1977), Colombia (Aguirre-C \& Rangel-CH 2007) and Bolivia (Flakus et al. 2016).

Additional specimens examined. VENEZUELA. Mérida: La Carbonera, sector El Pedregal, 2100 m, rocks in open pasture, 19 March 1975, M.E. Hale \& M. López Figueiras 44163 (US). Táchira: Slopes of Pico Banberas, above Betania, Páramo de Tama, 2600 m, disturbed mossy forest, 26 March 1975, M.E. Hale \& M. López Figueiras 45393 (US).

Parmotrema erubescens (Stirt.) Krog \& Swinscow, The Lichenologist 15(2): 127-130. 1983.

(Fig. 19B)

Basionym: Parmelia erubescens Stirt., Scottish Naturalist 4: 201.1878.

Type: Australia. Queensland: near Brisbane, F.M. Bailey 11 (lectotype-BM!, two larger pieces marked 'A', here designated: MBT 395070).

三Canomaculina erubescens (Stirt.) Elix, Mycotaxon 65: 477. 1997.

Description (based on lectotype). Thallus brown reddish (herbarium), lobate, loosely adnate, 3-4 cm broad. Lobes irregularly branched, laterally overlapped, 2-10 mm wide, surface continuous, smooth to scrobiculate, lustrous, becoming rugose, cracked and more deeply scrobiculate towards the center; apical zone rounded; margin broadly crenate to incised, undulated. Maculae distinct, effigurate, sometimes the irregular dots connecting in pseudoreticulate formations, laminal, originating cracks or not. Cilia black, simple or rarely furcated, up to $2 \mathrm{~mm}$ long, thin to thickened 0.02-0.06 mm wide, abundant. Lacinulae, pustules, soredia and isidia absent. Medulla white. Undersurface light brown or blackish brown only in the very center, lustrous, smooth to papillate, without cracks; marginal zone absent; rhizines black, dimorphic, the shorter ones simple to furcated or less frequently squarrose, up to $0.5(-1) \mathrm{mm}$ long, thin, $0.01-0.05 \mathrm{~mm}$ wide, abundant, evenly distributed; the longer ones up to $1.5 \mathrm{~mm}$ long, thickened, 0.05-0.1 mm wide, simple or branched, apparently frequent and distributed in groups.

Apothecia absent (according to Elix 1997, ascospores $10-12 \times 8-10 \mu \mathrm{m})$. Pycnidia submarginal to laminal, conspicuous, without prominent margin, frequent, ostiole black; conidia filiform, $8-11 \times \sim 1 \mu \mathrm{m}$.

Chemistry atranorin (minor), chloroatranorin (trace), salazinic acid (major), consalazinic acid (minor). Cortex $\mathrm{K}+$ yellow, UV-; medulla $\mathrm{K}+$ yellow $\rightarrow$ blood red, $\mathrm{C}-$, $\mathrm{KC}-, \mathrm{P}+$ strong yellow, $\mathrm{UV}-$.

Remarks. Parmotrema erubescens can be recognized by the brown reddish distinctly scrobiculate upper surface, effigurate maculae, dimorphic rhizines, brown undersurface and absence of propagules.

Hale (1965) first regarded Parmelia erubescens as conspecific with $P$. subcaperata. In this way, he was followed by Winnem (1975), Kurokawa (1991) and Elix (1994). Krog \& Swinscow (1981), however, segregated P. erubescens based on the absence of usnic acid (present in P. subcaperatum) and the presence of norlobaridone, which they found only in the African specimens. Actually, the lichen they named as $P$. erubescens could be another species, since the considerations constant in the item 'Circumscription of the species' and in Table 13 (Krog \& Swinscow 1981: 156) lled to the conclusion that the specimens with salazinic acid and norlobaridone are 'unnamed'. Some years later, Ferraro \& Elix (2000) described Parmotrema cristobaliae based on this chemical combination. So, the material studied by Krog \& Swinscow (1981) must be revised. These authors also referred the species to Brazil although without citing the specimens examined.

Finally, Elix (1997) became convinced that P. erubescens and $P$. subcaperata are distinct species, based on several aspects (see Table and comments under P. subcaperatum).

Unfortunately, the lectotype of $P$. erubescens lacks apothecia, and the specimens seen by Elix (1997) were not studied here. Nevertheless, the conidial size we found is very close to that found by him $(10-14 \mu \mathrm{m})$ and his description also matches the features we observed in the holotype.

The collection F.M. Bailey 11 at BM was selected by Rogers (1982) as lectotype. However, it is a mixed collection constituted by five thallus fragments glued on a paper card. Only two of them, the larger pieces, undoubtedly represent $\mathrm{P}$. erubescens according to the protologue, now marked "A"; these are here being selected as new lectotype, superseeding Rogers's original selection. The three other thalli (marked 'B') belong to another, unidentified species, with the upper surface grayish green, inconspicuous maculae, few cilia, the undersurface mostly black, brown only in the narrow marginal zone, and bacillar or slightly sublageniform conidia $5-6 \times \sim 1 \mu \mathrm{m}$; probably with stictic acid (medulla $\mathrm{K}+$ yellow, $\mathrm{C}-, \mathrm{KC}-, \mathrm{P}+$ orange).

The description of the lectotype underside is very incomplete, since the thalli are glued to the paper.

Distribution. South America (Kukwa et al. 2012), Africa (Krog \& Swinscow 1981; Swinscow \& Krog 1988) and Oceania (Winnem 1975; Krog \& Swinscow 1981; Swinscow \& Krog 1988; Elix 1997). In South America, it was 
recorded from Bolivia (Kukwa et al. 2012) and Brazil (Krog \& Swinscow 1981)

Parmotrema eurysacum (Hue) Hale, Phytologia 28(4): 336. 1974.

(Fig. 20)

Basionym: Parmelia eurysaca Hue, Nouvelles Archives du Muséum d'Histoire Naturelle de Paris, sér. 4(1): 194. 1899.

Type: Mexico. 1865-1866, M. Borgeau (holotype - P!).

Description (based on holotype). Thallus brownish, lobate, loosely adnate, corticicolous, $13.5 \mathrm{~cm}$ broad. Lobes irregularly branched, laterally overlapped to \pm crowded in the center, 5-13 mm wide, surface continuous, smooth, opaque to sublustrous, pruinose in some lobe apices; apical zone rounded; margin sinuous, undulated. Maculae extensive (hypermaculate). Cilia black, simple, up to $3.5 \mathrm{~mm}$ long, $0.05-0.1 \mathrm{~mm}$ wide, frequent. Lacinulae simple to furcated, plane or rarely subcanaliculated, apex acute, 3-10 × 0.4-2.5 mm, undersurface black to dark brown or sometimes with brown stains. Pustules, soredia and isidia absent. Medulla white or slightly salmon (salazinic acid?). Undersurface black, lustrous (satin-like),
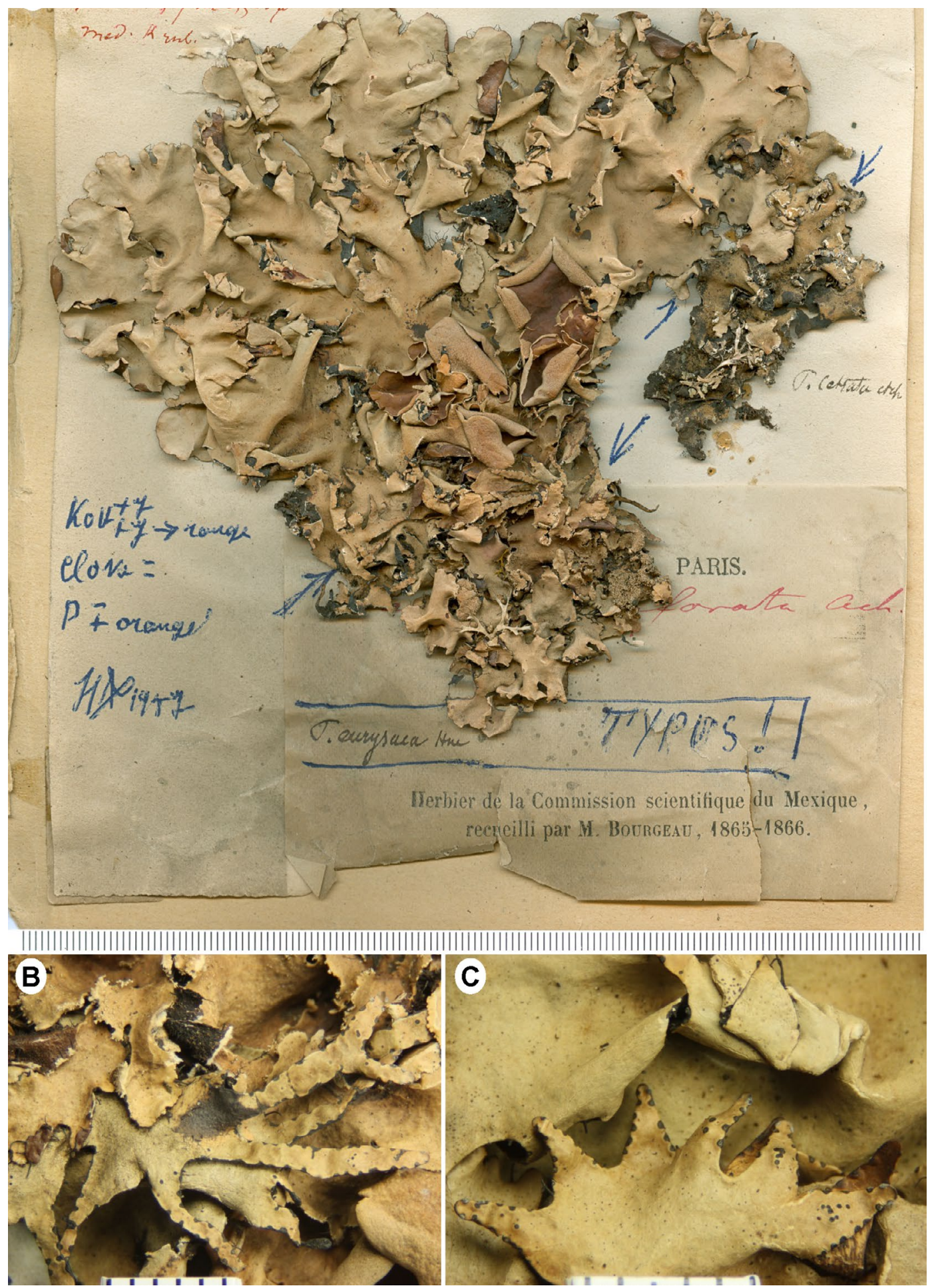

Figure 20. Holotype of Parmotrema eurysacum (PC). A - thallus; B and C - lacinulae. Scales in milimeters. 
smooth or sometimes slightly rugulose, with cracks; marginal zone brown to pale brown, lustrous, 2-5 $\mathrm{mm}$ wide, naked, with attenuated limit, smooth; rhizines black or dark brown near the marginal zone, simple to richly squarrose or irregularly branched, up to $2 \mathrm{~mm}$ long, 0.01-0.15 mm wide, frequent, evenly distributed, although leaving several naked areas.

Apothecia cupuliform, 4-22 $\mathrm{mm}$ in diameter, substipitate, margin involute, smooth to irregularly incised, amphithecium maculate, smooth or minutely scrobiculate, disc brown to dark brown, epruinose, widely perforate; ascospores ellipsoid, $12-15 \times 7.5-9 \mu \mathrm{m}$, episporium $\sim 1 \mu \mathrm{m}$. Pycnidia restricted to the lacinulae, [sub]marginal or subapical, conspicuous, with prominent margin and a distinct black outline, frequent, ostiole brown; conidia short-filiform, 6-9 $\times \sim 1 \mu \mathrm{m}$.

Chemistry. Atranorin (minor), chloroatranorin (trace), salazinic acid (major), consalazinic acid (minor), gyrophoric acid (minor). Cortex $\mathrm{K}+$ yellow, $\mathrm{UV}-$; medulla $\mathrm{K}+$ yellow $\rightarrow$ blood red, $\mathrm{C}-$, $\mathrm{KC}-$, $\mathrm{P}+$ strong yellow, $\mathrm{UV}-$.

Remarks. Parmotrema eurysacum is distinguished by the conspicuous lacinulae ornate with almost marginal black outlined pycnidia, the hypermaculate upper surface, long simple cilia, and the black undersurface with a bare, brown marginal zone. The wide lobes apparently emaculate (hypermaculate) make this species comparable to $P$. latissimum, which lacks lacinulae, has larger ascospores (27-35 $\mu \mathrm{m}$ long) and sublageniform conidia. Hale (1965) compared P. eurysacum to $P$. stuppeum, sorediate and with sublageniform conidia. The types of $P$. stuppeum studied here, however, are almost eciliate. Parmotrema acutatum also develops abundant lacinulae, but is eciliate, has longer conidia, 10-19 $\mu \mathrm{m}$, and the upper surface with effigurate maculae. One interesting feature of $P$. eurysacum is the black distinct outline around the pycnidia, which has, contrary to all species here seen, brown ostioles. These pycnidia are apparently marginal, however, the ostiole is open at the upper surface of the lacinulae.

Fleig (1997) proposed P. ruptum and P. expansum as synonyms of P. eurysacum. Parmotrema ruptum has reticulate maculae (sometimes hypermaculate) and rare, usually simple and shorter cilia (up to $0.5 \mathrm{~mm}$ ), while $P$. expansum (see below) presents effigurate maculae,

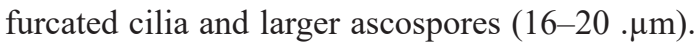

Hale \& DePriest (1999) proposed P. permaculatum as a synonym of $P$. eurysacum. Nevertheless, $P$. permaculatum lacks lacinulae, has effigurate maculae, shorter cilia (up to $2 \mathrm{~mm}$ ), and sometimes a white mottled marginal zone on the undersurface.

Based on the literature, we proposed a key and table assuming that all species inside the 'Parmotrema eurysacum complex' are good (Spielmann 2005), which proved to be effective after the types have been studied here.

Kurokawa (2001) asserted that in P. eurysacum the lacinulae are white in the undersurface, but this not happens with the holotype, where they are clearly black or at best dark brown or with some brown stains.
Distribution. North America (Hale 1965; Kurokawa 2001; Egan et al. 2016), South America (Kurokawa 2001), Africa (Krog \& Swinscow 1981) and Oceania (Elix 1994). In South America, it was reported from Brazil, Minas Gerais (Kalb 1982; Kurokawa 2001) and Rio Grande do Sul (Fleig 1997).

Additional specimens examined. MEXICO. Tamaulipas: Sierra de San Carlos, Vicinity of El Milagro, Cerro Zamora, 22.VIII.1930, H.H. Bartlett 11098, Herbarium Groenhart No. 1394 (L).

Parmotrema expansum Hale, Mycotaxon 5(2): 435. 1977.

Type: Costa Rica. San José: Patarrá, Desamparados, 1300 m alt., 04-VII-1948, on rocks, M. Guirós Calvo 1462 (holotype - US!; isotype - UPS).

Description (based on holotype). Thallus stramineous, lobate, loosely adnate, saxicolous, $21 \mathrm{~cm}$ broad. Lobes irregularly branched, laterally overlapped, 4-10 mm wide, with a thin to absent black line, surface continuous, smooth to slightly irregular, lustrous, usually pruinose at the lobe apices, becoming cracked and sometimes rugose towards the center; apical zone rounded; margin broadly crenate to deeply incised, undulated. Maculae distinct to strong, effigurate, sometimes very dense and becoming hypermaculate, laminal, originating cracks. Cilia black, simple to furcated or sometimes cespitose, up to $1.5 \mathrm{~mm}$ long, 0.04-0.1 mm wide, abundant. Lacinulae, pustules, soredia and isidia absent. Medulla white. Undersurface black, shiny, smooth to slightly rugose or reticulately veined, with cracks; marginal zone brown or stained with dark brown or black, lustrous to shiny, 2-4 mm wide, naked, with attenuated limit, smooth, slightly rugose or papillate, sometimes veined; rhizines black, simple or rarely branched near the apex, up to $1.5 \mathrm{~mm}$ long, $0.01-$ $0.05 \mathrm{~mm}$ wide, abundant, evenly distributed.

Apothecia \pm plane to cupuliform, 1-7 mm in diameter, substipitate, laminal, margin smooth to dentate, lacerate on old apothecia, sometimes forming ciliate lobes, amphithecium maculate, smooth to irregular, disc brown, epruinose, imperforate; ascospores ellipsoid, 16-20 × 9-11.5 $\mu \mathrm{m}$, episporium 1-1.5 $\mu \mathrm{m}$. Pycnidia submarginal to laminal, conspicuous, with or without prominent margin, abundant, ostiole black; conidia filiform, 7-12 $\times \sim 1 \mu \mathrm{m}$.

Chemistry. Atranorin (minor), chloroatranorin (trace), salazinic acid (major), consalazinic acid (minor). Cortex $\mathrm{K}+$ yellow, $\mathrm{UV}-$; medulla $\mathrm{K}+$ yellow $\rightarrow$ blood red, $\mathrm{C}-$, $\mathrm{KC}-, \mathrm{P}+$ strong yellow, $\mathrm{UV}-$.

Remarks. Parmotrema expansum is recognized by the effigurate maculae, commonly furcated cilia, black undersurface and ascospores medium-sized 16-20 $\mu \mathrm{m}$ long. It can be compared to $P$. bifidum, which also has furcated cilia, but presents somewhat darker and more ascendant lobes, a distinct black line in the lobe margins and the undersurface is pale brown. Other species with usually branched (cespitose) cilia also have lichexanthone in the medulla, like $P$. lichexanthonicum (without vegetative propagules) and P. spinibarbe (sorediate). 
Hale \& DePriest (1999) proposed P. expansum as a synonym of $P$. ruptum. However, $P$. ruptum is a clearly distinct species that has reticulate maculae (sometimes hypermaculate), rare, usually simple and shorter cilia (up to $0.5 \mathrm{~mm}$ ) and shorter ascospores $(10-12.5 \mu \mathrm{m}$ ).

The specimen Marcelli 2243, identified as P. expansum by Benatti (2005), was checked. It has similar cilia, but the overall morphology and color of the thallus, the shiny dark brown undersurface, the absence of effigurate maculae and the shorter conidia (6-9 $\mu \mathrm{m}$ according to Benatti 2005) make it not identifiable as $P$. expansum. Actually, it resembles those Parmotrema with both salazinic acid and lichexanthone, cited above. However, TLC analysis demonstrated only atranorin, salazinic and consalazinic acid. This chemical profile, combined with the features above can represent a new taxon. Unfortunately, it is sterile, so ascospores data could not be compared.

The holotype is constituted by two parts of the same thallus. The larger part was clearly cut at the middle, and perhaps that piece was sent to UPS, where the isotype is located (Hale 1977).

Distribution. Costa Rica and Brazil, where it was recorded from Minas Gerais (Hale 1977).
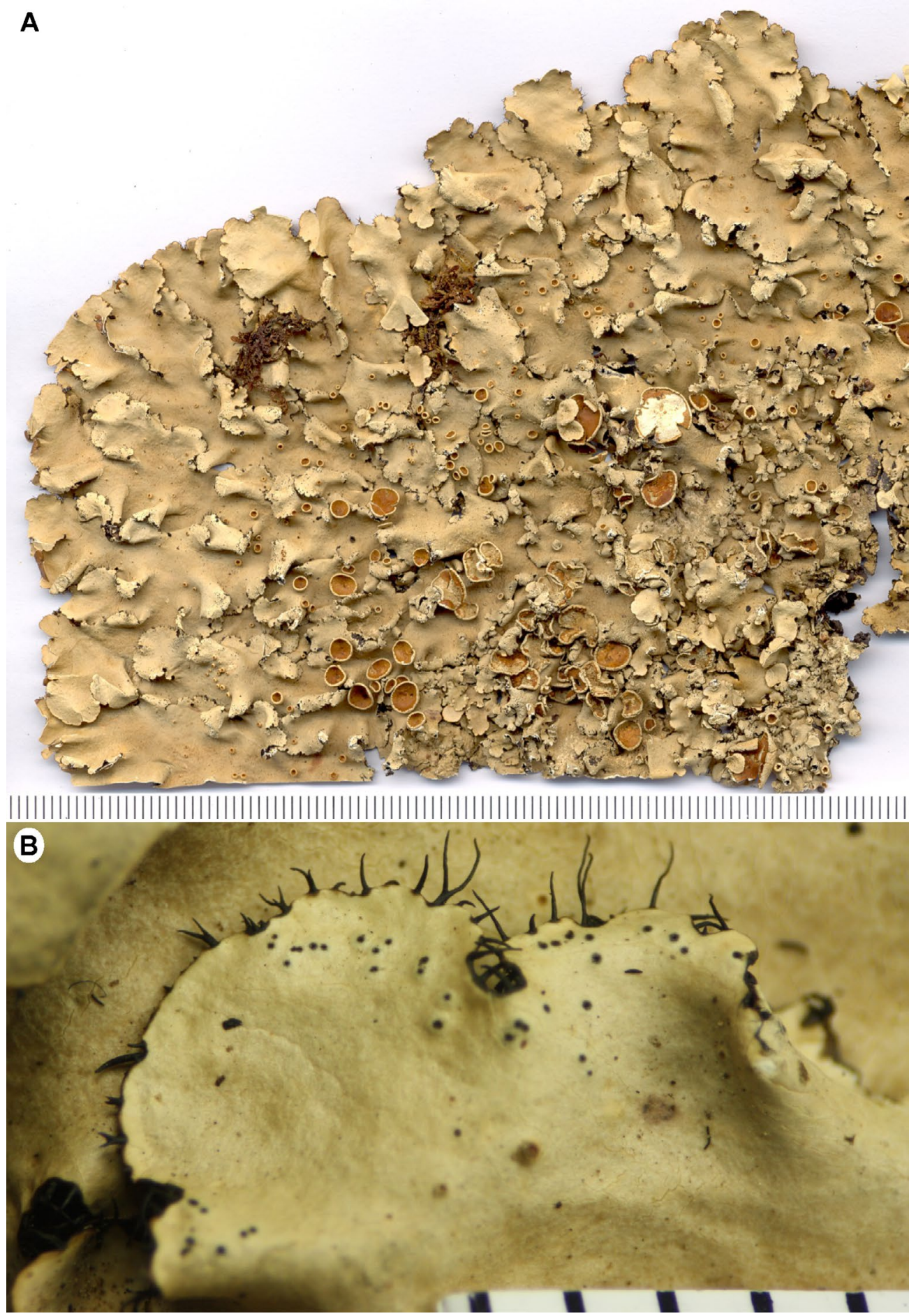

Figure 21. Holotype of Parmotrema expansum (US). A - thallus; B - lobe with furcated cilia and effigurate maculae. Scales in milimeters. 
Additional specimens examined. BRAZIL. São Paulo: São Sebastião, Centro de Biologia Marinha da USP (CEBIMAR), over rocks, 19.III.1988, M.P. Marcelli 2243 (SP).

Parmotrema flavescens (Kremp.) Hale, Phytologia 28(4): 336. 1974.

(Fig. 22A)

Basionym: Parmelia glaberrima var. flavescens Kremp., Flora 52(14): 223. 1869.

Type: Brazil. Rio de Janeiro: Rio de Janeiro, Glaziou 1833 (holotype - M!; isotype - H-NYL 35454!).

$\equiv$ Parmelia glaberrima f. flavescens (Kremp.) Kremp., Flora 59: 73.1876.

$\equiv$ Parmelia latissima f. flavescens (Kremp.) Müll. Arg., Linnaea 43: 32. 1880.

三Parmelia flavescens (Kremp.) Nyl., Flora 68: 607. 1885.

$\equiv$ Parmelia protoflavescens Zahlbr., Denkschriften der Mathematisch-Naturwissenschaftlichen Klasse der Kaiserlichen Akademie der Wissenschaften 83: 176. 1909. Illegitimate name based on Parmelia glaberrima $ß$ flavescens Kremp., according to Hale (1965).

= Parmelia pseudoflavescens Zahlbr., Denkschriften der Mathematisch-Naturwissenschaftlichen Klasse der Kaiserlichen Akademie der Wissenschaften 83: 176. 1909. Nomen nudum, according to Hale (1965).

= Parmelia mauriensis Hue, Nouvelles Archives du Muséum d'Histoire Naturelle de Paris, ser 4(1): 201. 1899.

Type: Mexico. San Luis de Potosí: Alrededores, Maury 7651 (holotype - PC!).

Description (based on holotype). Thallus yellowish $\tan$ (herbarium), lobate, loosely adnate, probably saxicolous, $15 \mathrm{~cm}$ broad. Lobes irregularly branched, crowded, 2-10 mm wide, surface continuous, usually smooth and lustrous; apical zone rounded; margin crenate to broadly crenate, or isidiate, undulated. Maculae inconspicuous, but extensive, do not forming cracks. Cilia black, simple or rarely furcated at the tip, $0.3-2 \mathrm{~mm}$, rare. Isidia with base concolor to the cortex, apex usually brown or sometimes concolor, simple to variously branched or coralloid, sometimes flattened, $0.1-2 \times 0.05-0.2 \mathrm{~mm}$, erect, firm, apex eciliate, mainly submarginal and marginal. Lacinulae, pustules and soredia absent. Medulla white. Undersurface black, lustrous, smooth, slightly rugose or papillate; marginal zone brown to dark brown, lustrous, 1-5 mm wide, naked, with an attenuated limit, smooth to slightly rugose or papillate; rhizines black, simple or furcated near the apices, up to $3 \mathrm{~mm}$ long, $0.05-0.1 \mathrm{~mm}$ wide, frequent, distributed in groups.

Apothecia absent. Pycnidia submarginal, conspicuous, without prominent margin, few, ostiole black; conidia short-filiform, 6-9 $\times \sim 1 \mu \mathrm{m}$.

Chemistry. Usnic acid (minor), atranorin (trace), salazinic acid (major), consalazinic acid (minor), gyrophoric acid (minor). Cortex $\mathrm{K}+$ yellow, $\mathrm{UV}-$; medulla $\mathrm{K}+$ yellow $\rightarrow$ blood red, $\mathrm{C}-, \mathrm{KC}-, \mathrm{P}+$ strong yellow, $\mathrm{UV}-$.

Remarks. Parmotrema flavescens is characterized by the presence of usnic acid, salazinic acid and isidia, together with the presence of only monomorphic rhizines. This combination is, as far as we know, unique in Parmotrema. Only P. neotropicum also produces isidia and has usnic acid, but is differentiated by the effigurate maculae and dimorphic rhizines. Related species with usnic and salazinic acids are $P$. delicatulum and $P$. masonii (without propagules) and the sorediate $P$. mirandum, $P$. nylanderi and $P$. pectinatum.

The holotype of $P$. flavescens (M) has a well-developed thallus, although somewhat friable, and is formed by some pieces that probably were part of the same thallus. The upper surface shows a peculiar pattern of whitish stains, which could well be characterized as maculae. However, we are not sure about the nature of this 'maculation', and maybe further anatomical studies could bring more information on the subject.

The isotype from $\mathrm{H}$ is undoubtedly part of the holotype. Together there is a part of a thallus of Cladonia, probably belonging to the $C$. verticillaris complex (according to Ahti \& Marcelli 1995). This could indicate that the type of $P$. flavescens is saxicolous.

The holotype of Parmelia mauriensis is constituted by two sheets, one with only one large thallus, and another with two thalli glued on a paper. The first was at some time already glued, as one can see looking at the undersurface, and it has a label from Hale dated 1962, indicating it as holotype. It is a large thallus with more cilia and abundant isidia. Apart from this, it agrees well with $P$. flavescens, including the conidia type and size. The second sheet contains two thalli that are possibly part of the same collection since the features are very similar.

Hale (1960) placed Parmelia microdactyla in the synonymy of $P$. delicatula and compared it to P. flavescens, the difference being the production of lobules instead of isidia. Indeed, rare flattened isidia can be seen in the holotype of $P$. flavescens. However, the total absence of isidia, together with a paler thallus, can set $P$. microdactyla closer to Parmotrema magnum.

The name Parmelia glaberrima Kremp. was rejected by Hale (1965), because it is a later homonym of Parmelia glaberrima Fries (Systema Orbis Vegetabilis 1: 283, 1825), a species of Lobaria, according to that author.

Distribution. North America (Hale 1965, Egan et al. 2016), Central America (Hue 1899, Hale 1965, Tenorio et al. 2002), South America (Hale 1965) and Africa (Müller Argoviensis 1880). In South America, it is known from Venezuela, Colombia (Hale 1965), Ecuador, Galapagos (Bungartz \& Spielmann 2019), Bolivia (Kukwa et al. 2012) and Brazil (Hale 1965), where it was recorded from Minas Gerais (Ribeiro 1998), Mato Grosso do Sul (Fleig \& Riquelme 1991), Paraná (Eliasaro 2001; Donha 2005; Gerlach \& Eliasaro 2014a), Pernambuco (Buril 2015), Rio de Janeiro (Krempelhuber 1869, 1876a; Nylander 1885; Hale 1965), Rio Grande do Sul (Fleig 1997), Santa Catarina (Gerlach \& Eliasaro 2014a) and São Paulo (Zahlbruckner 1909, Ribeiro 1998, Benatti 2005).

Parmotrema foliolosum (C.W. Dodge) Spielmann \& Marcelli, comb. nov.

(Fig. 22B-C)

\section{MycoBank MB 838184}

Basionym: Parmelia foliolosa C.W. Dodge, Annals of the Missouri Botanical Garden 46(1-2): 89. 1959. 


\section{A}
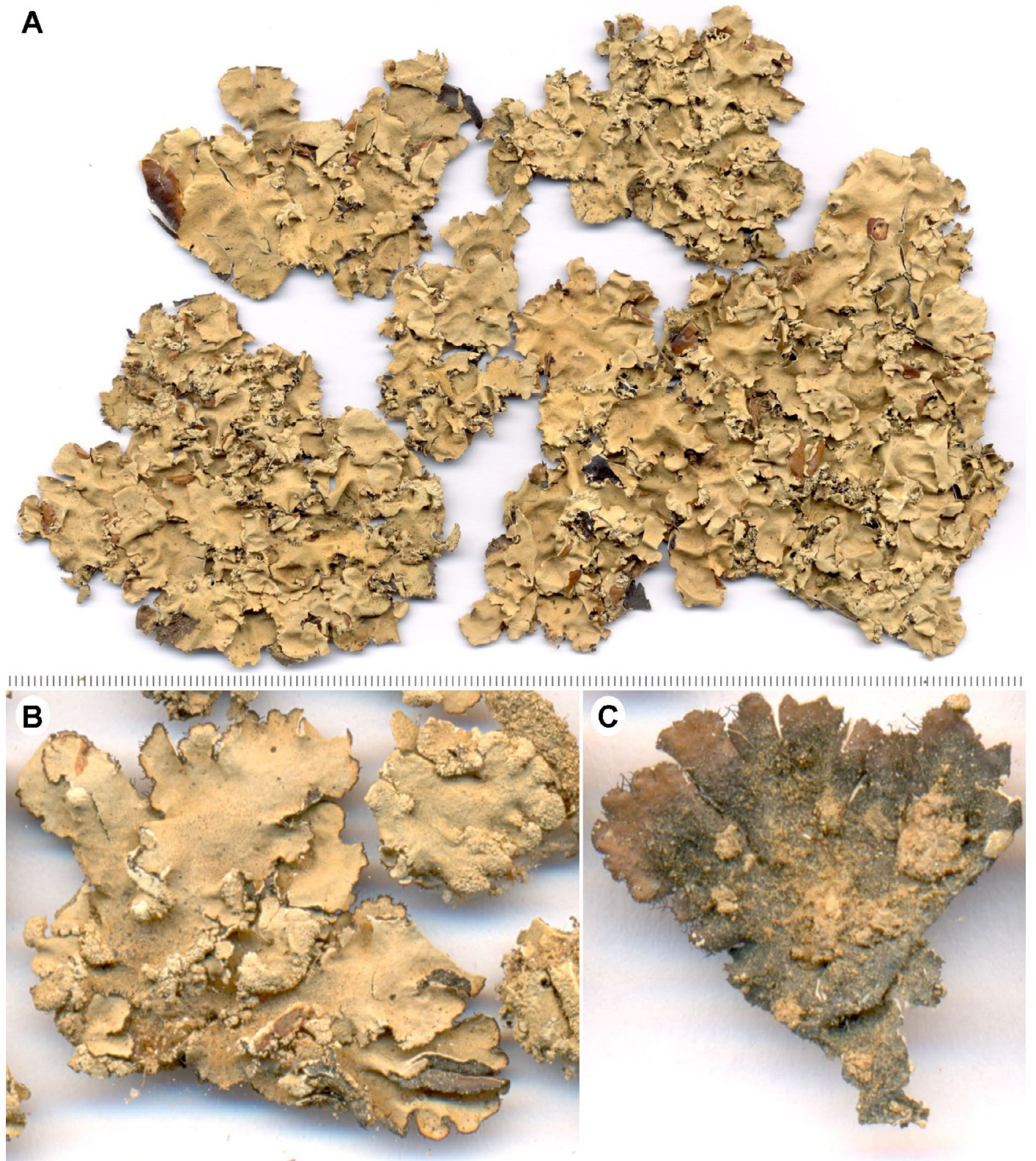

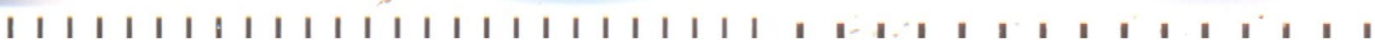

Figure 22. A - holotype of Parmotrema flavescens (M); B and C - holotype of Parmotrema foliolosum (FH), the hypermaculate upper surface (B) and the nude undersurface of the lobes (C). Scales in milimeters.

Type: Madagascar. East Imerina: Andrangolóaka [Dodge 1959 wrote 'Andrangolaoka'], terricolous, XI.1880, J.M. Hildebrandt (Comm. C. Rensch.), (holotype - FH!).

Description (based on holotype). Thallus grayish, lobate, loosely adnate, terricolous, formed by several pieces (according with the protologue reaching up to $6 \mathrm{~cm}$ ). Lobes irregularly branched, laterally overlapped, 1-6 mm wide, surface continuous, reticulate, sometimes cracked, smooth, and opaque, remaining continuous or becoming rugose in the older parts; apical zone rounded, often concave; margin usually crenate, sometimes sublacinulate, undulated. Maculae reticulate, laminal, sometimes extensive (hypermaculate), originating cracks. Cilia black, simple or rarely furcated, up to $0.5 \mathrm{~mm}$ long (usually shorter), abundant. Soralia usually in shapeless extensive formations, sometimes orbicular, often submarginal and turning the lobes involute; soredia farinose. Isidia, pustules and lacinulae absent. Medulla white. Undersurface black, lustrous, smooth or papillate, with few cracks; marginal zone dark brown, lustrous, 1-2 mm wide, naked or rarely rhizinate, with a attenuated limit, smooth or papillate; rhizines black, usually simple, sometimes thickened (as in Canomaculina) and branched, rarely squarrose, up to $1 \mathrm{~mm}$ long, abundant, more or less evenly distributed.

Apothecia absent. Pycnidia usually submarginal, conspicuous, without prominent margin, frequent, ostiole black; conidia filiform, (7-) 15-26(-30) $\times \sim 1 \mu \mathrm{m}$.

Chemistry. Atranorin (minor), chloroatranorin (trace), salazinic acid (major), consalazinic acid (minor), protocetraric acid (trace). Cortex $\mathrm{K}+$ yellow, UV-; medulla $\mathrm{K}+$ yellow $\rightarrow$ blood red, $\mathrm{C}-, \mathrm{KC}-, \mathrm{P}+$ strong yellow, $\mathrm{UV}-$. 
Remarks. Parmotrema foliolosum can be recognized by the reticulate to hypermaculate upper surface, short cilia (up to $0.5 \mathrm{~mm}$ ), long conidia (up to $30 \mu \mathrm{m}$ ), black marginal zone in the upper surface, and a brown nude marginal zone on the undersurface (Fig. 22C). There are also thickened and branched rhizines, resembling that of the former genus Canomaculina sensu Elix (1997). This species was placed as a synonym of $P$. reticulatum, which has only reticulate maculae (never hypermaculate) and shorter conidia (up to $12 \mu \mathrm{m}$ ).

Parmotrema foliolosum has the longest conidia of the genus, followed by those of $P$. austrocetratum (up to $25 \mu \mathrm{m}$ ) and $P$. arteagum (up to $23 \mu \mathrm{m}$, according to Egan 1982).

Distribution. Africa (Dodge 1959).

Parmotrema granulare (Asahina) Spielmann \& Marcelli, comb. et stat. nov.

(Fig. 23)

\section{MycoBank MB 838186}

Basionym: Parmelia cetrata f. granularis Asahina, The Journal of Japanese Botany 16: 593. 1940.
Type: Taiwan. Taichu: Keitau, 24.XII.1933, Y. Asahina 33125 (holotype - TNS!).

Description (based on holotype). Thallus brownish in herbarium, lobate, loosely adnate, corticicolous, $23 \times 16 \mathrm{~cm}$ broad. Lobes more or less radial, irregularly branched, contiguous, 4-11 mm wide, surface continuous, smooth, lustrous, becoming rugose and reticulated cracked in the center; apical zone rounded; margin broadly crenate, undulate or lacinulate. Lacinulae canaliculated, corniculate contorted, subdichotomous to subpalmate, localized in the whole thallus, but much more abundant in the center, apex usually acute, sometimes rounded, $1-12 \times 0.4-2 \mathrm{~mm}$. Maculae distinct, reticulate, laminal, originating cracks. Cilia black, simple to squarrose, $(0.1-) 1-2.5 \times 0.02-0.05 \mathrm{~mm}$, abundant. Pustules rugose to vesiculate, situated almost exclusively in the lacinulae, giving rise to soralia. Soralia pustular; soredia granular. Isidia absent. Medulla white. Undersurface black, lustrous, papillate, with numerous scars in the center; marginal zone brown, lustrous, 1-4 mm wide, naked, with an attenuated limit, papillate or with scarce rhizines, rarely veined; rhizines black, simple

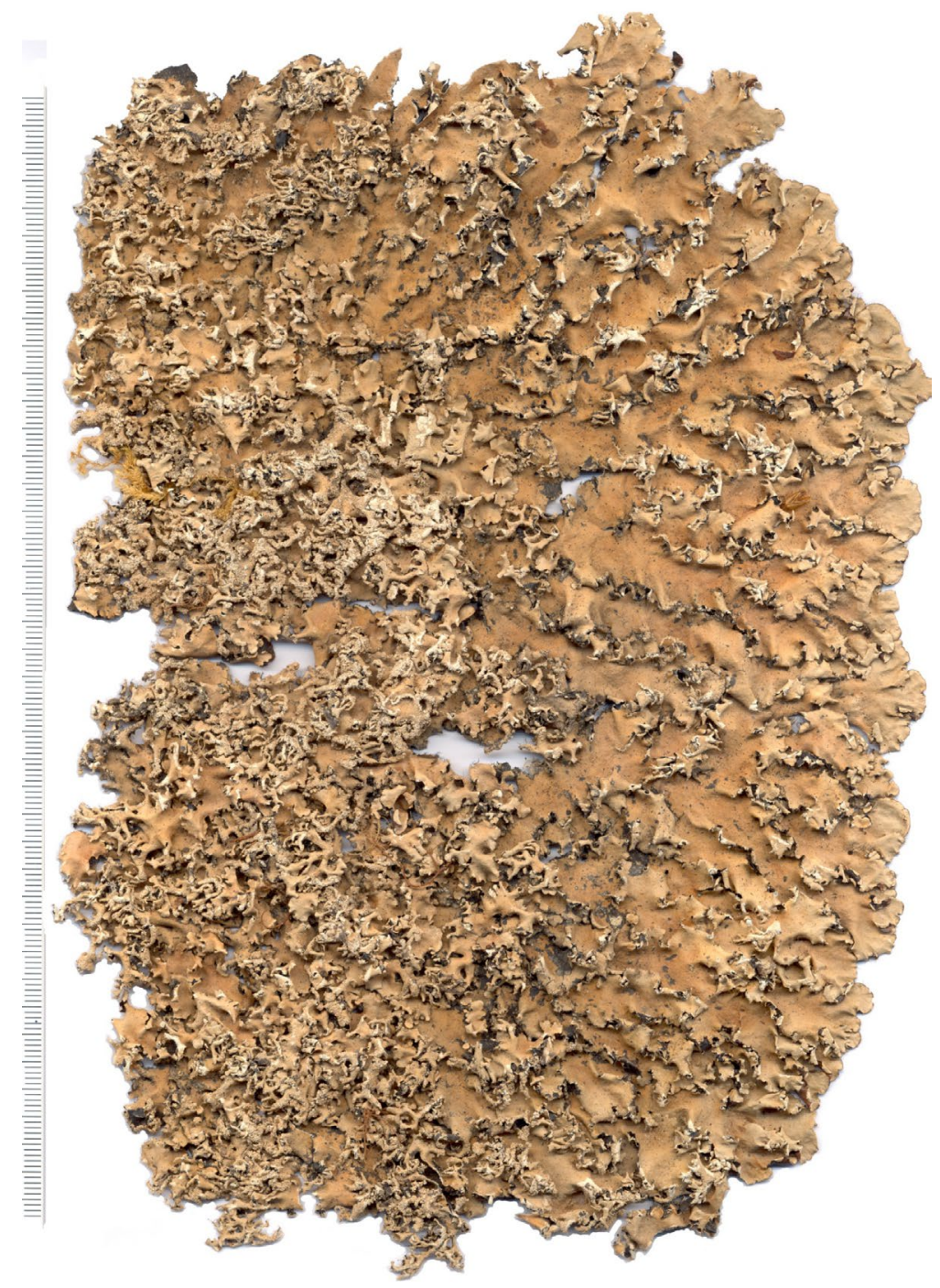

Figure 23. Holotype of Parmotrema granulare (TNS). Scales in milimeters. 
or squarrose, $(0.2-)$ 0.5-3 $\times 0.02-0.06 \mathrm{~mm}$, abundant, irregularly distributed.

Apothecia unknown. Pycnidia in the lacinulae, laminal or subapical, conspicuous, with or without prominent margin, few, ostiole black; conidia filiform, 7.5-13 $\times$ $\sim 0.5 \mu \mathrm{m}$.

Chemistry. Atranorin and salazinic acid. Cortex $\mathrm{K}+$ yellow, UV-; medulla $\mathrm{K}+$ yellow $\rightarrow$ blood red, $\mathrm{C}-$, $\mathrm{KC}-$, $\mathrm{P}+$ strong yellow, UV-.

Remarks. Parmotrema granulare is distinguished by the vesicular and rugose pustules along the lacinulae, the reticulate maculae, the ciliate margin and the presence of salazinic acid. The thallus is relatively large $(23 \times 16 \mathrm{~cm})$ with wide lobes $(4-11 \mathrm{~mm})$. This species was first described as Parmelia cetrata f. granularis (Asahina 1940). Afterward, Asahina (1952) placed it as a synonym of Parmelia cetrata f. subisidiosa Müll. Arg. Apparently it was studied only by Asahina himself, and fortunately, Hale \& Fletcher (1990) listed it as a synonym of $P$. reticulatum. However, $P$. reticulatum is a not pustulate species whose soralia are extensively submarginal or situated in short lacinulae $(0.5-2.2 \mathrm{~mm})$, has a smaller thallus $6.5-7 \mathrm{~cm}$, presents crowded lobes and shorter cilia $(0.1-1 \mathrm{~mm})$.

The holotype of $P$. granulare is well-developed, with the necessary features to characterize the species, except the apothecia. Fertile specimens, from the type locality (Taiwan) or close locations could bring more data about this taxon, known only by the holotype.

The presence of the numerous vesicular pustules probably led Asahina (1940) to propose the epithet 'granularis'.

Distribution. Taiwan (Asahina 1940, 1952).

Parmotrema herrei (Zahlbr.) Spielmann \& Marcelli, Bibliotheca Lichenologica 106: 217. 2011.

(Fig. 24)

Basionym: Parmelia herrei Zahlbr. in Herre, Proceedings of the Washington Academy of Sciences 7: 353. 1906.

Type: USA California: Santa Cruz Peninsula, Pilarcitos Canyon, two miles from sea, $200 \mathrm{ft}, \mathrm{V}$. 1904, Herre 516 (lectotype - FH!; isolectotypes - FH!, W!).

This combination has been recently proposed (Marcelli et al. 2011). The specimens cited below are tentatively placed as $P$. herrei, since although they present the overall resemblance of the lobes and cilia (including some of the characteristic furcated or more branched cilia), the same chemistry and the same substrate (rock, or in soil over rock), one of them (R. Santesson \& R. Moberg P49:13) develops some cracked areas, usually the older ones, that give rise to tiny lacinulae. Those seem to be features caused by some injuries. Apothecia are absent and pycnidia empty, so ascospores and conidia data could not be taken.

We emphasize that new collections from South America, including the highlands, are highly desirable to help to understand more this species. By the time, the known distribution of Parmotrema herrei is extended from the type locality (USA, California) to Argentina and Peru, South America.

Distribution. USA (California, type locality), Peru and Argentina.

Additional specimens examined. PERU. Huanuco: Prov. Dos de Mayo, $55 \mathrm{Km}$ (road distance) WNW of Huanoco, near Cayanillo, $09^{\circ} 50^{\prime} \mathrm{S}, 76^{\circ} 35^{\prime} \mathrm{W}, 3.800 \mathrm{~m}$ alt., on soil on boulder, 24.II.1981, R. Santesson \& R. Moberg P49:13 (UPS). Ancash: Prov. Huaraz, the pass $\mathrm{W}$ of Conococha (road Huaraz-Pativilca), $10^{\circ} 07^{\prime} \mathrm{S}, 77^{\circ} 23^{\prime} \mathrm{W}, \sim 3.900 \mathrm{~m}$ alt., on a boulder, 01.III.1981, R. Santesson \& R. Moberg P62:59 (UPS). ARGENTINA. Salta: Valle Encantado in the Sierra de Candado near top of escarpment, $25^{\circ} 12^{\prime} \mathrm{S}, 65^{\circ} 50^{\prime} \mathrm{W}, \sim 3100 \mathrm{~m}$, on sandstone, 25.V.1989, T.H. Nash 27839 (MIN).

Parmotrema laciniellum (Ferraro \& Elix) Blanco, Crespo, Divakar, Elix \& Lumbsch, Mycologia 97(1): 157. 2005.

(Figs 3, 25A)

Basionym: Canomaculina laciniella Ferraro \& Elix, Mycotaxon 74(2): 391. 2000.

Type: Argentina. Corrientes: Depto. Monte Caseros, Timboy Stream along Route 122, $13 \mathrm{Km}$ W of Monte Caseros, on trees at the forest margin, A. Schinini et al. 19705, 10.IX.1979 (holotype - CTES!; isotype - US).

Description (based on holotype). Thallus brownish (herbarium), lobate, loosely adnate, corticicolous, $13 \mathrm{~cm}$ broad. Lobes irregularly branched, laterally overlapped to \pm crowded, 3-7 mm wide, intensely lacinulate, surface continuous, smooth or with shallow rounded depressions, lustrous, becoming irregularly cracked towards the center; apical zone usually lacinulate. Maculae distinct, punctiform to mainly effigurate, sometimes becoming pseudoreticulate, laminal, originating cracks. Cilia black, simple or rarely with lateral branchlets, short, up to $0.5 \mathrm{~mm}$ long (usually shorter), $0.01-0.05 \mathrm{~mm}$ wide, abundant. Lacinulae simple or dichotomous, present in the whole thallus, plane to subcanaliculated, apex acute or rarely truncate, $1-15 \times 0.3-3.5 \mathrm{~mm}$, undersurface black or more commonly brown, rhizinate. Pustules, soredia and isidia absent. Medulla white. Undersurface black, lustrous, smooth to veined, with cracks; marginal zone brown, lustrous, 2-7.5 mm wide, rhizinate, with attenuated limit, papillate; rhizines black, simple to squarrose or irregularly branched, up to $2 \mathrm{~mm}$ long, very thin to sometimes thickened, $0.01-0.15 \mathrm{~mm}$ wide, but with transitional rhizines between the two extremes, \pm evenly distributed.

Apothecia cupuliform, 1-5 $\mathrm{mm}$ in diameter, stipitate, laminal or submarginal, margin smooth to incised or sometimes lacerate, amphithecium maculate, smooth to slightly scrobiculate, becoming longitudinally rugose and with deep depressions towards the base, disc pale brown to brown, epruinose, perforate at maturity; ascospores ellipsoid, $12-14 \times 7-9 \mu \mathrm{m}$, episporium $\sim 1 \mu \mathrm{m}$. Pycnidia subapical, occurring in the lacinulae, conspicuous, with or without prominent margin, frequent, ostiole black; conidia filiform, 9-16 $\times \sim 1 \mu \mathrm{m}$.

Chemistry (TLC in solvent C, HPLC - J.A. Elix, 24.VI.1999, label with the holotype): atranorin (minor), 

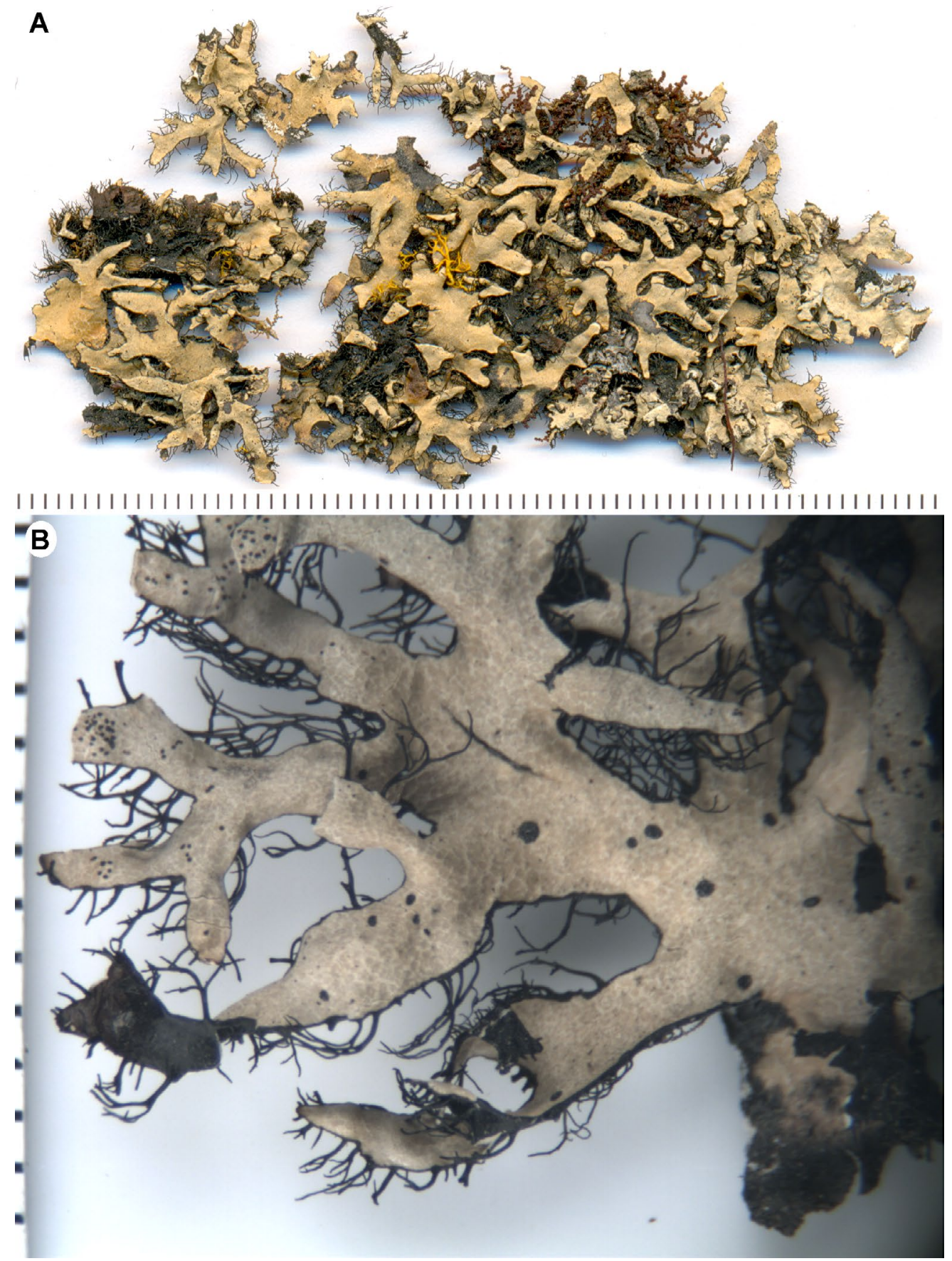

Figure 24. Parmotrema herrei. A - lectotype (FH); B - isolectotype (FH), showing reticulate maculae and branched cilia. Scales in milimeters.

chloroatranorin (minor), usnic acid (trace), salazinic acid (major), consalazinic acid (minor), protocetraric acid (trace). Cortex $\mathrm{K}+$ yellow, $\mathrm{UV}-$; medulla $\mathrm{K}+$ yellow $\rightarrow$ blood red, $\mathrm{C}-, \mathrm{KC}-, \mathrm{P}+$ strong yellow, $\mathrm{UV}-$.

Remarks. Parmotrema laciniellum is characterized by the abundant lacinulae, effigurate maculae, short cilia (up to $0.5 \mathrm{~mm}$ long) and black undersurface. Morphologically, it is quite close to a synonym of Parmotrema cetratum, namely Parmelia perforata var. corniculata, which can be differentiated by the strictly reticulate maculae (effigurate only near some apothecia), longer cilia and lacinulae with usually bare undersurface.

Parmotrema eurysacum and P. acutatum also develop long lacinulae. The first has long cilia (up to $3.5 \mathrm{~mm}$ ) and the upper surface hypermaculate, while the later is eciliate and with effigurate maculae.

Distribution. Bolivia (Flakus et al. 2016), Brazil (Gerlach \& Eliasaro 2014a) and Argentina (Ferraro \& Elix 2000). In Brazil it is known only from Santa Catarina (Gerlach \& Eliasaro 2014a).

Parmotrema lacteum Marcelli \& Spielmann, Bibliotheca Lichenologica 96: 215. 2007.

(Fig. 25B)

Type: Brazil. Rio Grande do Sul, Boqueirão do Leão, Cascata do Gamelão, saxicolous on the rocky wall downstream from the

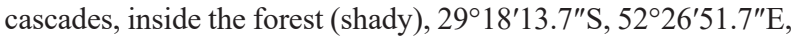
$500 \mathrm{~m}$ alt, 01.II.2004, A. A. Spielmann \& M. A. Sulzbacher 1307 (holotype - SP!). 
Parmotrema lacteum is recognized by the milk-white thallus coloration, the commonly subsquarrose cilia, the capitate sorediose clusters originating isidioid soredia, the orange pigment in the apices of the lacinulae, and the presence of salazinic and consalazinic acids. Parmotrema subisidiosum (Müll. Arg.) Hale (holotype - G) is distinguished by the shorter, simple cilia (up to $0.6 \mathrm{~mm}$ ), and the formation of marginal to laminal, simple to coralloid true isidia, $0.1-0.2 \times 0.05-0.15 \mathrm{~mm}$, that remain entire or can form granules, but not soredia. Parmotrema bonplandii (Mata) Blanco, Crespo, Divakar, Elix \& Lumbsch, produces norlobaridone and lichexanthone in the medulla (Mata García 1994). Finally, P. clavuliferum is somewhat similar in forming soredia on the lacinulae, but never produces isidioid structures.

This species has now the distribution extended to São Paulo in Brazil, Ecuador, Galapagos (Bungartz \& Spielmann 2019) and South Africa (Cape Province). The specimen from South Africa is tentatively assigned to this species, since although having the characteristic isidioid soredia in some lobes apices, it is quite fragmentary, and the black line margin is more developed when compared with the Brazilian specimens.

Distribution. In South America, known from Ecuador, Galapagos (Bungartz \& Spielmann 2019) and Brazil, Rio
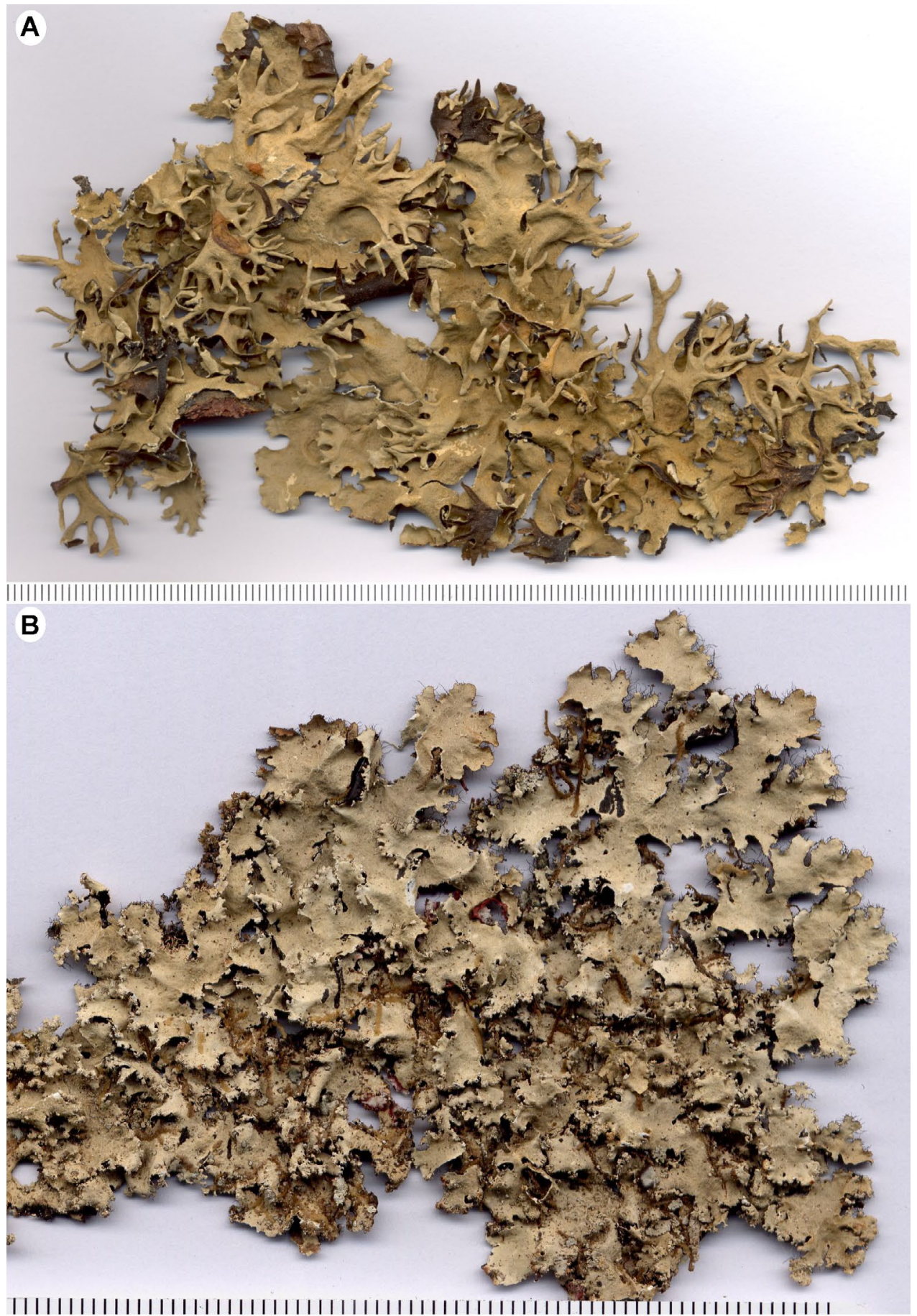

Figure 25. A - holotype of Parmotrema laciniellum (CTES); B - holotype of Parmotrema lacteum (SP). Scales in milimeters. 
Grande do Sul (Marcelli et al. 2007) and São Paulo. Also here reported from Africa, Cape Province.

Additional specimens examined. BRAZIL. Rio Grande do Sul: Municipality of Boqueirão do Leão, Cascata do Gamelão, saxicolous on the rocky wall downstream from the cascades, inside the forest (shady), $29^{\circ} 18^{\prime} 13.7^{\prime \prime} \mathrm{S} 52^{\circ} 26^{\prime} 51.7^{\prime \prime} \mathrm{W}, 500 \mathrm{~m}$ alt., 01.II.2004, A.A. Spielmann \& M.A. Sulzbacher 748, 751 (SP). São Paulo: Municipality of São Luís do Paraitinga, Parque Estadual da Serra do Mar, Núcleo Santa Virgínia, near the director's house, $23^{\circ} 19^{\prime} 43,0^{\prime \prime} \mathrm{S}, 45^{\circ} 08^{\prime} 26,3^{\prime \prime} \mathrm{W}, 915 \mathrm{~m}$ alt., corticicolous, field with forest in the surroundings, exposed, 14.I.2007, A.A. Spielmann, P. Jungbluth, L.S. Canêz \& M.J. Kitaura 3362 (SP). Idem, at Trilha da Pirapitinga, $23^{\circ} 20^{\prime} 17,2^{\prime \prime} \mathrm{S}$, $45^{\circ} 08^{\prime} 45,8^{\prime \prime} \mathrm{W}, 915 \mathrm{~m}$ alt., corticicolous, forest border, exposed, 14.I.2007, A.A. Spielmann, P. Jungbluth, L.S. Canêz \& M.J. Kitaura 3343 (SP). AFRICA. UNION OF SOUTH AFRICA. Cape Province: Table Mountain, Platte Klip, on rocks, $\sim 1000 \mathrm{~m}$ alt., 20.XII.1949, R.A. Maas Gesteranus 6821 (L).

Parmotrema latissimum (Fée) Hale, Phytologia 28(4): 337. 1974.

(Fig. 26A)

Basionym: Parmelia latissima Fée, Ess. Crypt., Suppl.: 119, pl. 38, fig. 4. 1837.

Type: Jamaica. S.c. (lectotype - G!; isolectotype - G!, Herbier Müller Arg.).

Description (based on lectotype). Thallus brownish, lobate, loosely adnate, $12.5 \mathrm{~cm}$ broad. Lobes irregularly branched, laterally overlapped, very large, 6-25 mm wide, surface continuous, smooth, lustrous, becoming slightly rugose and irregularly cracked in the center; apical zone rounded; margin smooth, undulated, occasionally with some adventitious lobules. Maculae absent. Cilia absent. Lacinulae, pustules, soredia and isidia absent. Medulla white. Undersurface (based on the isolectotype in $\mathrm{G}$, except the large nude marginal zone): black, lustrous, smooth to papillate in some restricted areas, with extensive cracks; marginal zone brown, lustrous, up to $15 \mathrm{~mm}$ wide, naked, with attenuated limit, smooth.

Apothecia concave to cupuliform, up to $15 \mathrm{~mm}$ in diameter, substipitate, laminal or submarginal, margin incised to lacerate, often involute, amphithecium maculate, rugose to irregularly areolate-cracked, disc dark brown, epruinose, imperforate or perforate in one apothecium; ascospores ellipsoid, large, 27-35 × 15-17 $\mu \mathrm{m}$, episporium 2-3 $\mu \mathrm{m}$. Pycnidia submarginal or less commonly laminal, conspicuous, with or without prominent margin, abundant, ostiole black; conidia sublageniform, 6-8 $\times \sim 1 \mu \mathrm{m}$.

Chemistry. atranorin (minor), chloroatranorin (minor), salazinic acid (major), consalazinic acid (minor). Cortex $\mathrm{K}+$ yellow, $\mathrm{UV}-$; medulla $\mathrm{K}+$ yellow $\rightarrow$ blood red, $\mathrm{C}-$, $\mathrm{KC}-, \mathrm{P}+$ strong yellow, $\mathrm{UV}-$.

Remarks. Parmotrema latissimum can be recognized by the wide lobes, sublageniform conidia and absence of cilia and propagules. The general morphology, conidia and ascospores are similar to those of $P$. cristiferum. This supports the idea that they constitute a species pair, as already asserted by Hale (1965). Parmotrema mantiqueirense also has wide lobes and lack propagules, but develops conspicuous cilia and has filiform conidia.

The lectotype of $P$. latissimum is totally glued to a paper card, so the underside could not be described with the exception of the marginal zone. Our brief description was based on the isolectotype (G!).

The typification of this species also requires some comments. From the three specimens we received upon request, two have Hale's annotations: 1) the specimen from 'Jamaica insula' (G00053795), with the label information about his publication and which exactly correspond to the plate published by Fée (1837), was annotated as 'isotype' [actually the lectotype] by Hale in $1962 ; 2)$ the specimen growing 'ad ramos cinchonarum' (G00053796), was annotated as 'Parmelia zollingeri Hepp' by Hale in 1962.

In our opinion, the specimen G00053975 is the lectotype of Parmelia latissima, designated by Hale, since it has the Hale's handwriting and exactly the same data cited by him in his monograph (Hale 1965).

The specimen G00053796 is actually composed of three glued thalli on a card. The thallus on the right of the card we labeled ' $\mathrm{A}$ '. It has a well-developed, imperforate apothecium, sublageniform conidia, $6-8 \times \sim 1 \mu \mathrm{m}$, ascospores ellipsoid, $27-33 \times 13-16.5 \mu \mathrm{m}$, episporium 2-3 $\mu \mathrm{m}$. The upper cortex contains probably atranorin $(\mathrm{K}+$ yellow) and the medulla is $\mathrm{K}+$ brownish, $\mathrm{C}-, \mathrm{KC}-$ and $\mathrm{P}+$ yellow $\rightarrow$ quickly orange (protocetraric acid?). The thallus on the left of the card (labeled 'B') has also sublageniform conidia $(6-8 \times \sim 1 \mu \mathrm{m})$ and the same reactions as the ' $\mathrm{A}$ ' thallus. In 1962, Hale labeled this specimen as Parmelia zollingeri. However, future studies are necessary since the list of synonyms of this species is long, and Hale (1965) apparently employed a broad species concept, accepting both specimens ciliate and eciliate as belonging to the same taxa (see also Elix 1998).

Finally, the thallus in the middle of the card (' $\mathrm{C}$ ') is an isidiate lichen with the upper cortex $\mathrm{K}+$ yellow (atranorin) and the medulla $\mathrm{K}-, \mathrm{C}+$ red, $\mathrm{KC}+$ red and $\mathrm{P}-$ (lecanoric acid), clearly belonging to Parmotrema tinctorum or some close species.

The third specimen (G00053794) available for the study has a label from Müller Argoviensis (dated 1896) indicating the published data from Fée (1837) and another from R.v. Aubel (dated 22.II.1985) indicating that this is the lectotype, according to Hale (1965). However, there are no Hale's annotations with this specimen; thus, we believe that Hale really never saw it. It is identical morphologically (including the sublageniform conidia) and chemically with the specimen G00053975, and so this specimen (G00053794) can be named as 'isolectotype'.

Distribution. North, Central and South America (Hale 1965; Egan et al. 2016), Asia (Hale 1965; Divakar \& Upreti 2005). In South America, it was reported from Venezuela, Colombia (Hale 1965), Ecuador, Galapagos (Bungartz \& Spielmann 2019), Peru (Hale 1965), Bolivia (Kukwa et al. 2012) and Brazil (Hale 1965). In Brazil, it was recorded from Mato Grosso (Hale 1965), Mato Grosso do Sul (Fleig \& Riquelme 1991) and Santa Catarina (Gumboski \& Eliasaro 2011). 
Parmotrema leucosemothetum (Hue) Hale, Phytologia 28(4): 337. 1974.

(Figs 2D, 26B, 27A)

Basionym: Parmelia leucosemotheta Hue, Nouvelles Archives du Muséum d'Histoire Naturelle de Paris, sér. 4(1): 192. 1899.

Type: Mexico. Surroundings of San Luis Potosí, December 1886, P. Maury 7650 (holotype - PC!).

三 Canomaculina leucosemotheta (Hue) Elix, Mycotaxon 65: 477. 1997.

Description (based on holotype). Thallus brownish (herbarium), lobate, loosely adnate, $13-15 \mathrm{~cm}$ broad. Lobes irregularly branched, laterally overlapped, 6-17 mm wide, surface continuous or irregularly cracked, smooth, with some irregular depressions, lustrous, becoming rugose and reticulately cracked towards the center; apical zone rounded; margin broadly crenate-incised or sublacinulate, undulated. Maculae strong, effigurate, laminal, originating cracks. Cilia black, simple and usually thickened and \pm tapering, up to $2.5(-3) \mathrm{mm}$ long, $0.04-0.1 \mathrm{~mm}$ wide, abundant. Soralia whitish, marginal or in the apex of the sublacinulae, linear interrupted; soredia farinose to subgranular. Lacinulae, pustules and isidia absent. Medulla white. Undersurface dark brown to blackish in some central areas, shiny, smooth to rugose and scrobiculate, also with some veins, with cracks; marginal zone absent or
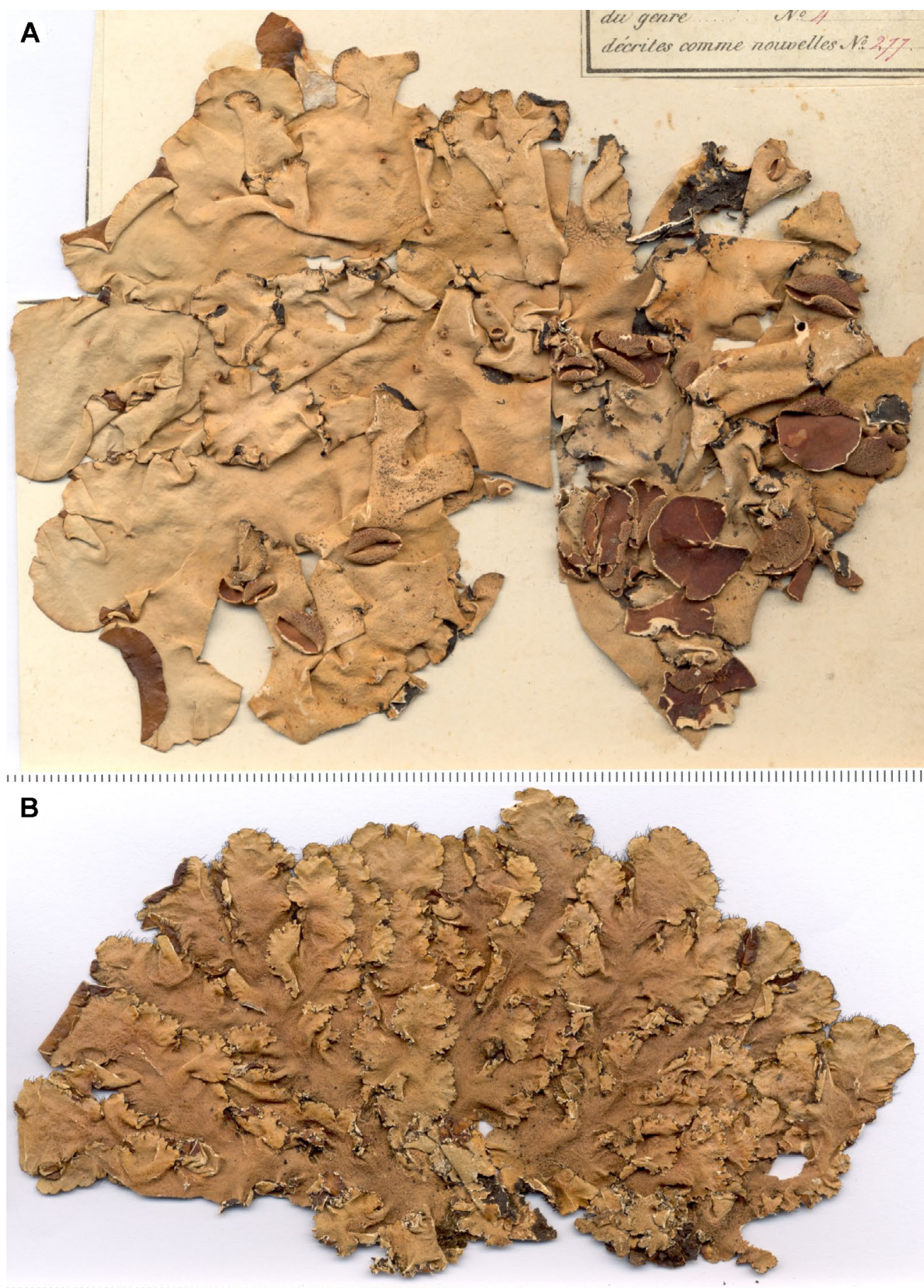

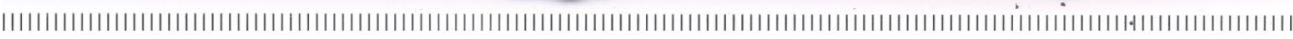

Figure 26. A - lectotype of Parmotrema latissimum (G); B - holotype of Parmotrema leucosemothetum (PC). Scales in milimeters. 


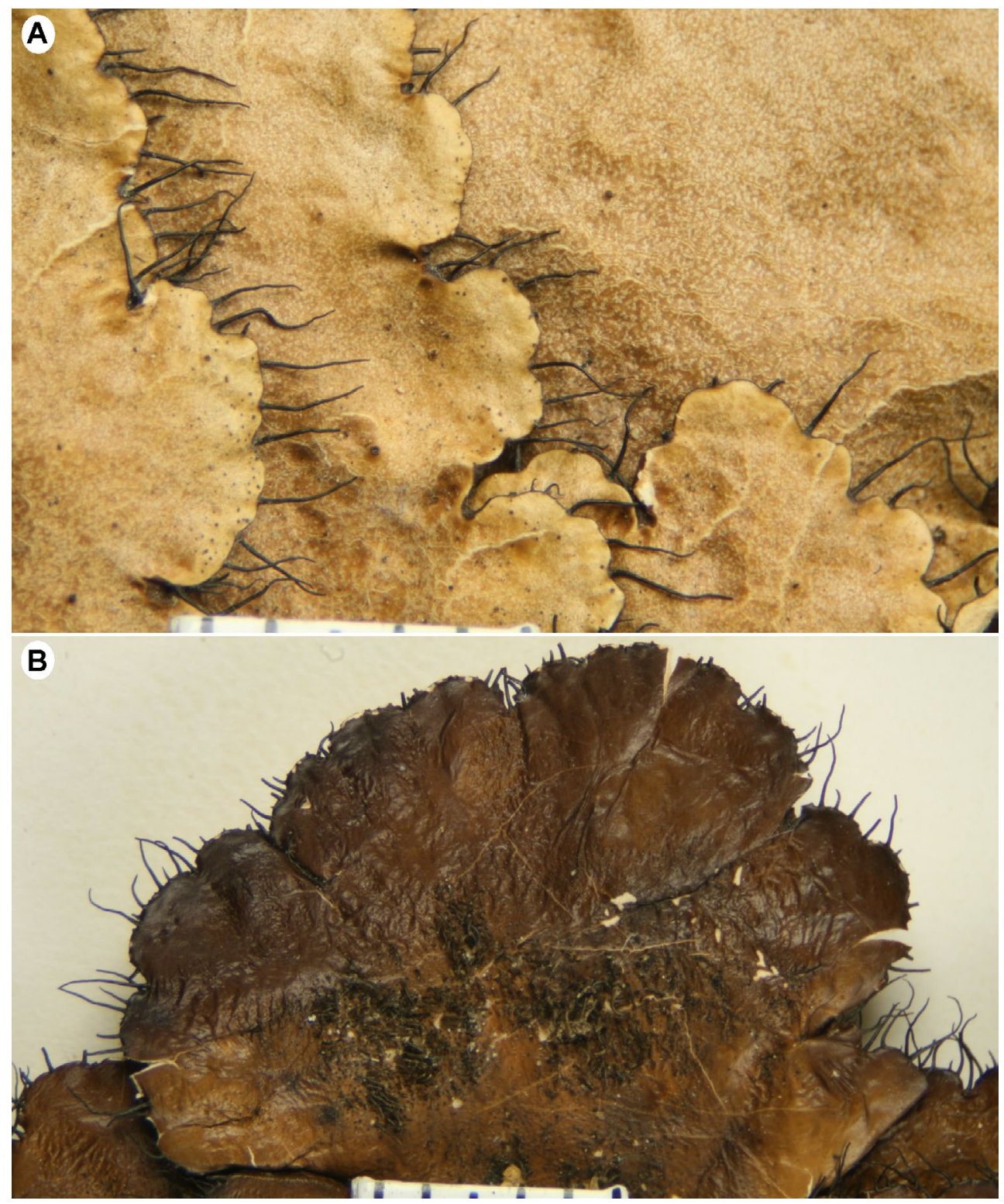

Figure 27. Holotype of Parmotrema leucosemothetum (PC). A -upper surface and cilia; B - undersurface of a lobe. Scales in milimeters.

usually dark brown and shiny, naked; rhizines black or concolor to the undersurface, monomorphic, up to $2 \mathrm{~mm}$ long, usually thickened, $0.02-0.2 \mathrm{~mm}$ wide, simple or irregularly branched, especially near the apices, abundant, distributed in groups.

Apothecia absent [according to Hale (1965), apothecia rare, \pm adnate, to $6 \mathrm{~mm}$ in diameter, amphithecium sorediate, disc imperforate or rarely perforate; ascospores $12-16 \times 7-10 \mu \mathrm{m}]$. Pycnidia submarginal to laminal, conspicuous, usually without prominent margin, frequent, ostiole black; conidia filiform, $8-12 \times \sim 1 \mu \mathrm{m}$.

Chemistry. Atranorin (minor), chloroatranorin (trace), salazinic acid (major), consalazinic acid (minor). Cortex $\mathrm{K}+$ yellow, $\mathrm{UV}-$; medulla $\mathrm{K}+$ yellow $\rightarrow$ blood red, $\mathrm{C}-$, $\mathrm{KC}-, \mathrm{P}+$ strong yellow, $\mathrm{UV}-$.

Remarks. Parmotrema leucosemothetum is characterized by the soralia almost exclusively marginal, the strongly maculate upper cortex (Fig. 2D), the simple, usually thickened and \pm tapering cilia (Fig. 27A), and the distinct bare marginal zone on the undersurface (Fig. 27B). It has been confused continuously with $P$. subsumptum, which has the marginal soralia growing backwards on the undersurface, scarce cilia (if present) and weak maculae. Parmotrema petropoliense, another close species, has slender bifurcate cilia.

A striking feature to note is that in P. leucosemothetum holotype the thickened rhizines are much more common than the slender ones. Usually, in this group (formerly Rimeliella), the contrary is the rule, i.e., the slender rhizines are more common than the thickened rhizines.

Krog \& Swinscow (1981) reduced P. leucosemothetum to synonymy of $P$. subsumptum, based on the variation they found in African species. Fleig (1997) accepted this synonym. However, those authors do not discuss some critical features to distinguish both species, namely the cilia and the maculation. Based on the types here studied, they are clearly distinct taxa, and the specimens identified by those authors should be revisited to clarify their identity.

Also, the record from Vareschi (1962) to Venezuela needs to be checked, since judging from the published 
picture, it seems to have reticulate maculae and capitate soralia growing in lacinulae, typical of the species formerly placed under Rimelia.

The holotype collection consisted of two larger well-preserved thalli and one smaller ( $5 \mathrm{~cm}$ broad), not as characteristic as the others. Apothecia are absent. Hale (1965) gave a description of apothecia he found probably in some additional specimens examined (see above in the description).

Distribution. Americas (Hue 1899, Hale 1965, Nash \& Elix 2002a, Egan et al. 2016), Africa (Winnem 1975, Hale 1965, Krog \& Swinscow 1981) and Asia (Kurokawa \& Lai 2001). In South America, it is known from Venezuela (Vareschi 1962, 1973), Bolivia (Kukwa et al. 2012), Brazil and Argentina (Hale 1965). In Brazil, it was recorded from Minas Gerais (Hale 1965), Paraná (Osorio 1977b), Rio Grande do Sul (Canêz 2005) and São Paulo (Hale 1965).

Parmotrema lichexanthonicum Eliasaro \& Adler, Mycotaxon 63: 49. 1997.

(Fig. 28A)

Type: Brazil. Minas Gerais: Municipality of Santana do Riacho, Serra do Cipó, Alto Palácio, $19^{\circ} 22^{\prime} \mathrm{S}, 43^{\circ} 32^{\prime} \mathrm{W}$, saxicolous, in 'campo rupestre', 01.II.1989, S. Eliasaro 807 (holotype - UPCB-24699!; isotypes - BAFC-37875! and CANB).

Description (based on holotype). Thallus brownish (herbarium), lobate, loosely adnate, saxicolous, $13 \mathrm{~cm}$ broad. Lobes irregularly branched, somewhat crowded, 5-15 mm wide, surface continuous or inconspicuously reticulate-cracked in some lobes, usually smooth, lustrous to opaque, becoming slightly cracked in the older lobes; apical zone more or less rounded to irregular; margin broadly crenate, sinuous, undulated. Maculae weak, effigurate or assuming a pseudoreticulate pattern, more visible in the amphithecia. Cilia black, simple or more usually cespitose, short $0.2-0.6(-1) \times 0.01-0.05 \mathrm{~mm}$, frequent, friable (sparse for almost all upper surface). Lacinulae, pustules, isidia and soredia absent. Medulla white. Undersurface black, lustrous, strongly papillate, with cracks, rarely veined; marginal zone absent to black or dark brown, lustrous, 1-3 mm wide, naked, with an attenuated limit, smooth or papillate; rhizines black, simple or rarely furcated, although sometimes difficult to ascertaining since usually the rhizines are glued in tufts by their apices, frequently short, $0.1-0.6(-1) \times 0.01-$ $0.04 \mathrm{~mm}$, very abundant, evenly distributed.

Apothecia cupuliform, 1-10 $\mathrm{mm}$ in diameter, stipitate, submarginal to laminal, margin smooth or sometimes deeply dentate, amphithecium maculate, rugose, disc dark brown, epruinose, perforate; ascospores slightly ovoid to ellipsoid, $14-16.5 \times 6.5-7.5 \mu \mathrm{m}$, episporium $\sim 1 \mu \mathrm{m}$. Pycnidia laminal to more usually submarginal, conspicuous, with or without prominent margin, abundant, ostiole black; conidia short-filiform, 6.5-9 $\times \sim 1 \mu \mathrm{m}$.

Chemistry. Atranorin (minor), chloroatranorin (trace), salazinic acid (major), consalazinic acid (minor), lichexanthone (minor). Cortex $\mathrm{K}+$ yellow, $\mathrm{UV}$-; medulla $\mathrm{K}+$ yellow $\rightarrow$ blood red, $\mathrm{C}-$, $\mathrm{KC}-$, $\mathrm{P}+$ strong yellow, $\mathrm{UV}+$ yellow.
Remarks. Parmotrema lichexanthonicum is characterized by the presence of cespitose cilia, medulla with lichexanthone and salazinic acid, and the absence of vegetative propagules. The presence of cespitose cilia in this species is remarkable (Ribeiro 1998). It is correlated with the presence of lichexanthone in the medulla. Similar species with salazinic acid and lichexanthone include $P$. pontagrossense and P. spinibarbe (sorediate), and P. ultralucens (isidiate).

While identifying specimens of Parmotrema lichexanthonicum, we realized that the medulla does not always show an evident bright yellow under the UV lamp. Donha (2005) noticed the same for $P$. pontagrossense and suggested the TLC analysis as essential to assure the presence of lichexanthone. However, in our observations we noted that the presence of cespitose cilia, combined with a dark reddish-brown shiny marginal zone, can be a indication of the medullar lichexanthone presence in Parmotrema species. A special study of the chemical composition of $P$. lichexanthonicum was performed by Micheletti et al. (2009).

Both the holotype and isotype are well-developed thalli, and the isotype (BAFC) agrees well with the holotype in all features. Indeed, the faint maculate upper surface is more easily seen in this thallus.

A concerning and relatively recent problem is the exploration of Brazilian lichens on a commercial scale. Christensen \& Sipman (1998) noted that Brazilian lichens were sold in European markets. They thought that one of the species was Parmotrema cetratum (Ach.) Hale. However, close examination of the specimens deposited in $\mathrm{C}$ proved they are actually Parmotrema lichexanthonicum. Therefore, it is possible that this apparently endemic lichens may be an endangered species.

Distribution. Known from Brazil, where it was recorded from Minas Gerais (Eliasaro \& Adler 1997; Ribeiro 1998) and São Paulo (Ribeiro 1998).

Parmotrema lividotessellatum (Hue) Spielmann \& Marcelli, comb. nov.

(Figs 28B, 29A-B)

\section{MycoBank MB 838187}

Basionym: Parmelia lividotessellata Hue, Nouvelles Archives du Muséum d'Histoire Naturelle de Paris, sér. 4(1): 191, plate V, fig. 2.

Type: Uruguay. Montevideo, Cerro Melones, saxicolous, June 18, 1876, Fruchart s.n. (lectotype - PC!; isotypes - TUR!).

Description (based on lectotype). Thallus brownish (herbarium), lobate, loosely adnate, saxicolous and over mosses, up to $27 \mathrm{~cm}$ broad (combining the parts). Lobes irregularly branched, somewhat crowded, growing in multiple directions (i.e., not radial), 5-15 mm wide, surface continuous to reticulate-cracked, opaque to lustrous, strongly maculate, pruinose in some lobe apices; apical zone rounded; margin sublacinulate, with well marked incisions. Maculae strong, reticulate, sometimes extensive (hypermaculate), originating cracks. Cilia black, simple to furcated, rarely more branched, sometimes thickened, $1-3.5 \times 0.05-0.2 \mathrm{~mm}$, abundant. Soredia farinose, initially 
coming from the margins of the areolae, coalescing with the age and forming plane or extensive, laminal or more commonly submarginal soralia, sometimes with a pustular appearance. Lacinulae simple, projected from the margin of the lobes, plane, apex rounded/to \pm truncate, up to $5 \mathrm{~mm}$ long, $0.5-2 \mathrm{~mm}$ wide. Isidia absent. Medulla white. Undersurface black, lustrous, usually papillate, less commonly smooth or rugose, with cracks; marginal zone dark brown, lustrous, 1.5-4 mm wide, naked, with an attenuated limit, usually smooth, rarely slightly papillate; rhizines black, simple or sometimes squarrose or furcated, $0.2-2.5 \times 0.02-0.1 \mathrm{~mm}$, abundant, irregularly distributed.
Apothecia concave, 5-6 $\mathrm{mm}$ in diameter, substipitate, laminal, margin incised (difficult to define since the apothecia are not in good conditions), amphithecium scrobiculate, disc brown, epruinose, apparently perforate; ascospores ellipsoid, $13 \times 6.5-7.5 \mu \mathrm{m}$, episporium $\sim 1 \mu \mathrm{m}$ (see the notes below). Pycnidia not found (several black structures investigated, but without conidia).

Chemistry (TLC in solvent C, HPLC - J.A. Elix, 25.II.1996, label with the isotype). Atranorin (major), chloroatranorin (minor), salazinic acid (major), consalazinic acid (minor). Color tests: cortex K+ yellow, UV-;
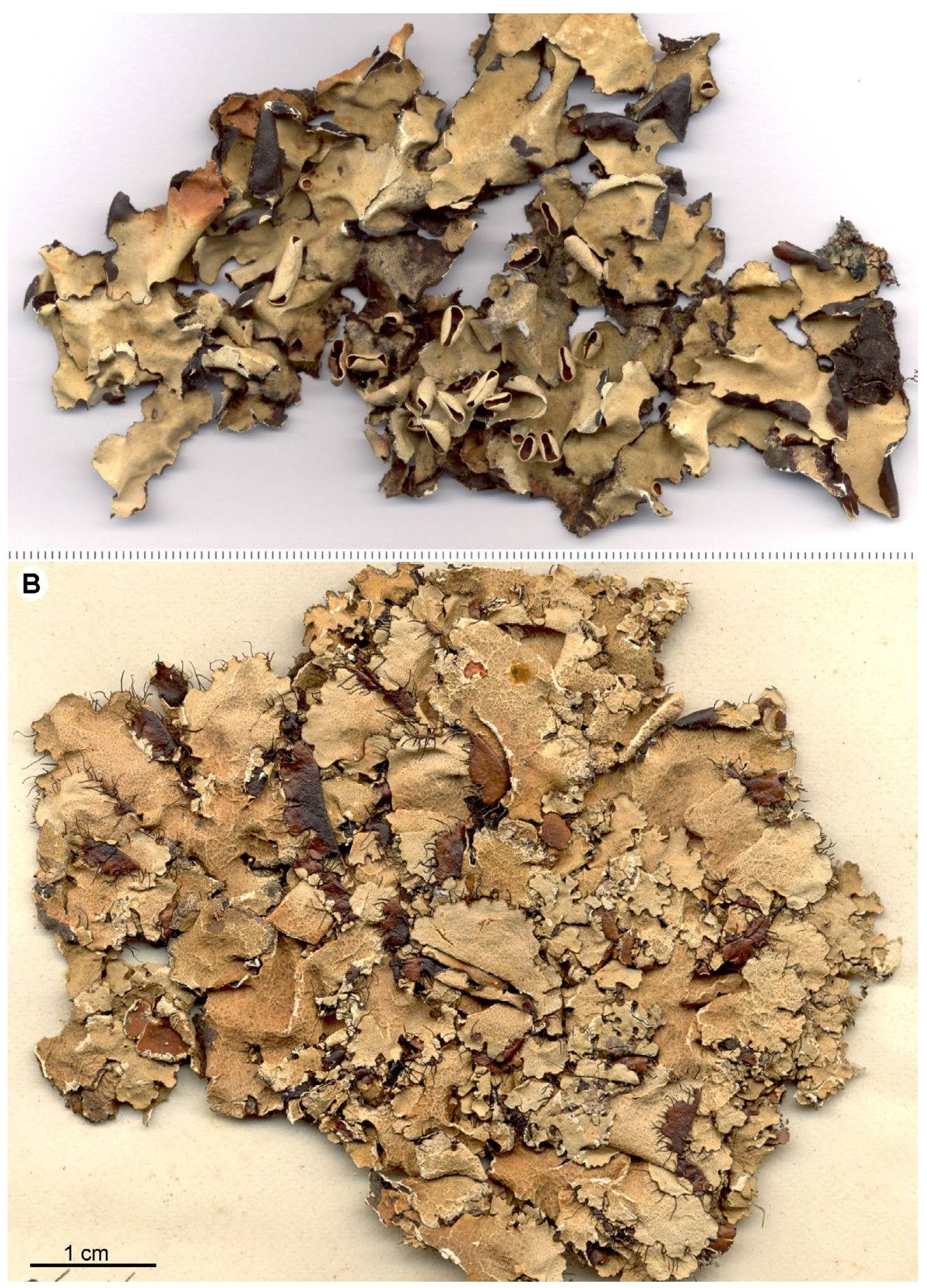

Figure 28. A - holotype of Parmotrema lichexanthonicum (UPCB); B - lectotype of Parmotrema lividotesselatum (PC). Scales in milimeters, except as indicated. 

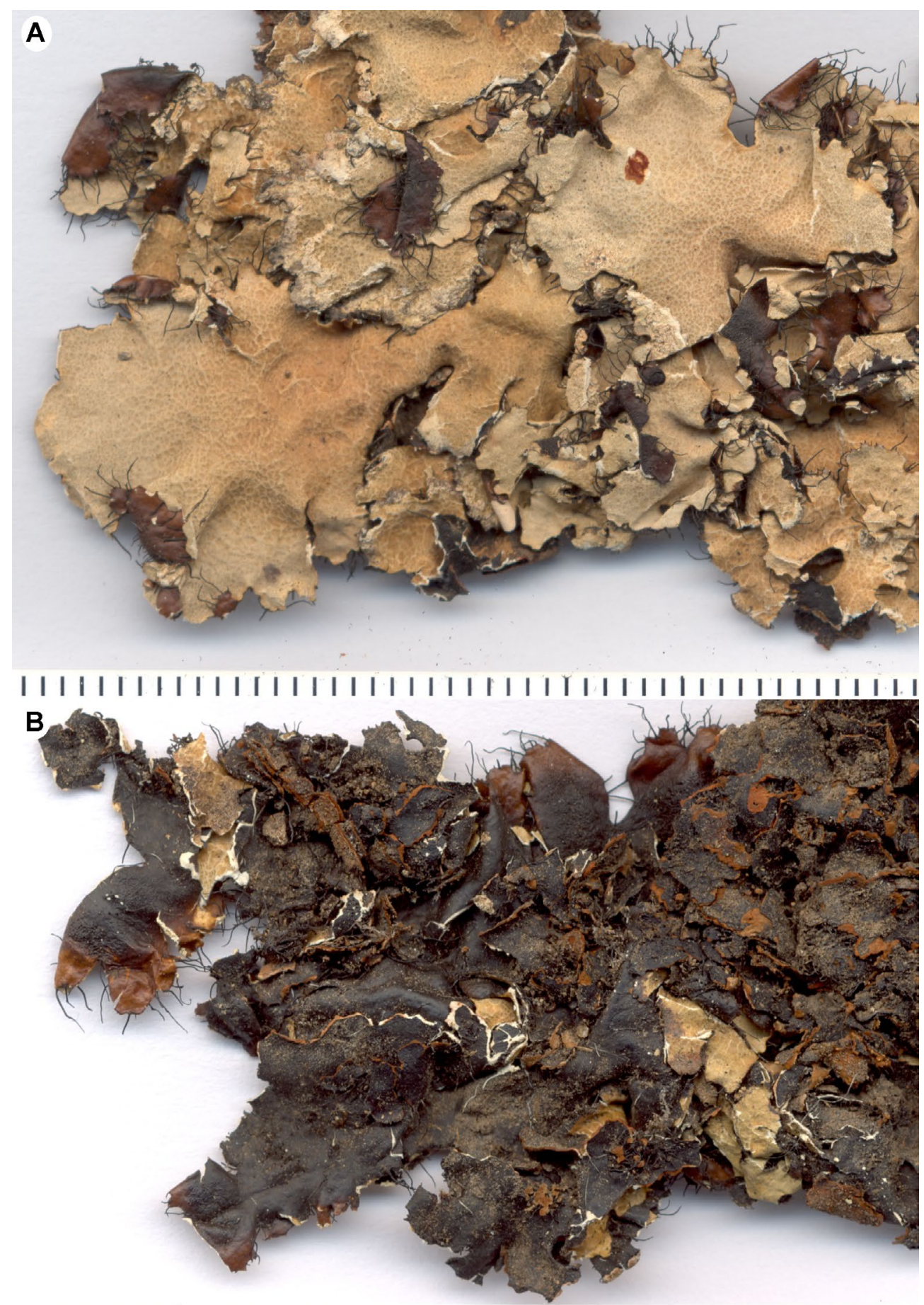

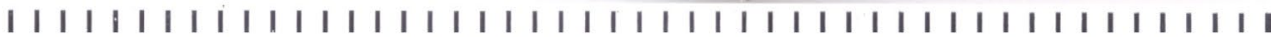

Figure 29. Isotype of Parmotrema livido-tesselatum (TUR). A - upper surface; B - undersurface. Scales in milimeters.

medulla $\mathrm{K}+$ yellow $\rightarrow$ blood red, $\mathrm{C}-, \mathrm{KC}-, \mathrm{P}+$ strong yellow, UV-.

Remarks. Parmotrema lividotessellatum has a wide and distinct bare zone on the underside, thickened, tortuous, tapering and usually furcated cilia, an upper surface strongly maculate, and the soralia often laminal and eruptive rose from the thallus cracks. Hale \& Fletcher (1990) situated this species as a synonym of Rimelia reticulata. Actually, this lichen is closer to Parmotrema austromaculatum, differing by the presence of soredia. It is also interesting to note that, in P. lividotessellatum, the sorediate lobes do not become involute, as commonly happens to other 'rimelioid' species.

The lectotype collection (PC) is composed of four thalli, or possibly parts of just one thallus, since Hue's (1899) thallus measurement was $27 \mathrm{~cm}$ wide, which agrees with our observation. One of the parts contains two smashed apothecia, and is glued to a paper with the annotation 'n. 33'. Apparently, Hue saw just one apothecia, the most developed, and we chose the second one to take the ascospore measurements, as to preserve the main apothecium. The hymenium is not well-developed, and just two ascospores were found. They are $13 \times 6.5-7.5$, 
so matching the variation described in the protologue $(12-16 \times 7-8 \mu \mathrm{m})$.

There are two samples preserved in TUR, numbered '02620' and '02621', which were part of the Herbarium Vainio. They are very similar in every feature with the lectotype from PC, and the labels are indicating 'isotype'. In fact, it seems clearly that they are parts of the collection from PC. However, Hue's (1899) original publication cited two collections: one from Uruguay and another from 'Africa meridionalis'. Probably this information led Hale \& Fletcher (1990) to choose the specimen from PC as lectotype, and the specimen from TUR (probably only the n. 02620 , since it is the only one with Hale annotations) as 'isolectotype'.

The specimen referred by Hue (1899) to South Africa needs to be revised since it can indicate an interesting distribution pattern.

Distribution. Uruguay and South Africa (Hue 1899; Zahlbruckner 1930a).

Parmotrema magnum (Lynge) Spielmann \& Marcelli, comb. nov.

(Fig. 30)

MycoBank MB 838188

Basionym: Parmelia magna Lynge, Arkiv för Botanik 13(13): 83. 1914.

Type: Brazil. Minas Gerais: Municipality of São João d'el Rey [del Rei], 31.VIII.1892, G.O.A. Malme 269 (holotype - S!; isotypes - LD!, MO, UPS!).

= Parmelia microdactyla Hale, Contributions from the United States National Herbarium 36(1): 21. 1960 (Fig. 31).

Type: Brazil. [Rio de Janeiro]: Municipality of Rio de Janeiro, 'På översta toppen av Corcovado' [at the very top of the Corcovado mountain], Fr. Widgren (holotype - UPS!; isotype - S!).

Description (based on holotype). Thallus yellowish, lobate, loosely adnate, probably saxicolous, $17 \mathrm{~cm}$ broad. Lobes irregularly branched, laterally overlapped to crowded, 5-15 mm wide, surface continuous, smooth, sublustrous, becoming slightly rugose towards the center; apical zone rounded; margin crenate to sinuous, undulated. Maculae absent. Cilia black, simple or furcated, up to $1.5 \mathrm{~mm}$ long, $0.05-0.1 \mathrm{~mm}$ wide, few. Lacinulae, pustules, soredia and isidia absent. Medulla white. Undersurface black, sublustrous, smooth to rugulose, papillate near the margins, or rarely with veins, with cracks; marginal zone dark brown, lustrous, 1-3.5 mm wide, naked, with an attenuated limit, smooth or rugulose; rhizines black, simple or rarely irregularly branched, delicate, up to $2.5 \mathrm{~mm}$ long, $0.02-0.06 \mathrm{~mm}$ wide, abundant, distributed in groups.

Apothecia flattened or cupuliform, usually lacerate and with the margins involute, up to $10 \mathrm{~mm}$ in diameter, short stipitate, submarginal, margin smooth or incise, amphithecium maculate, rugose or scrobiculate at maturity, disc brown, epruinose, imperforate; ascospores ellipsoid, $10-12.5 \times 7.5-8 \mu \mathrm{m}$, episporium $\sim 1 \mu \mathrm{m}$. Pycnidia submarginal, conspicuous, with or without prominent margin, frequent, ostiole black; conidia short-filiform, 6-7.5 $\times 1 \mu \mathrm{m}$.
Color tests: cortex $\mathrm{K}+$ yellow, $\mathrm{UV}-$; medulla $\mathrm{K}+$ yellow $\rightarrow$ blood red, $\mathrm{C}+$ rose, $\mathrm{KC}+$ red, $\mathrm{P}+$ strong yellow, $\mathrm{UV}-$.

Chemistry (TLC in solvent C, HPLC - J.A. Elix, 10.V.1996, label with the holotype in S). Usnic acid (minor), salazinic acid (major), consalazinic acid (minor), gyrophoric acid (major), lecanoric acid (trace).

Remarks. Parmotrema magnum can be recognized by the yellowish (usnic acid), large thallus (up to $17 \mathrm{~cm}$ ) and wide lobes $(5-15 \mathrm{~mm})$, with few cilia up to $1.5 \mathrm{~mm}$ long. The apothecia are usually lacerate, with a rugose to scrobiculate amphithecia. The medulla reacts $\mathrm{C}+$ rose, $\mathrm{KC}+\mathrm{red}$, an indicative of the abundance of gyrophoric acid. It is close to $P$. delicatulum, from which it was already considered a synonym (Hale 1965). However, $P$. delicatulum has a smaller sublaciniate thallus with narrow lobes (1-3.5 mm), cilia abundant, simple and longer (up to $2.8 \mathrm{~mm}$ ), and smooth entire amphithecia. Although the gyrophoric acid was reported from this species (see above), it is not abundant enough to cause a positive spot test, and so the medulla is $\mathrm{C}-, \mathrm{KC}-$. These differences are being considered here as discriminatory to maintain these taxa as distinct species. However, the examination of additional specimens shows that the cilia can be quite a variable feature. Future studies with additional specimens from a wider area may corroborate this positioning.

Parmelia microdactyla (Hale 1960, Fig. 31A) was distinguished based on the presence of marginal lobules (Fig. 31B) and very sparse cilia. Later on, Hale (1965) assumed this difference as a morphological variation, and situated $P$. microdactyla as a synonym of $P$. delicatula (together with $P$. magna). The holotype is represented by a well-preserved thallus $8.5 \mathrm{~cm}$ broad, with pruinose lobes (at the apices), abundant lobules and rare, short cilia (up to $0.5 \mathrm{~mm}$ long). It is also very close to Parmotrema flavescens, which isotype (S) was found growing together. However, no sign of isidia was found. The chemistry of the isotype was made through TLC in solvent C and HPLC (J.A. Elix, 10.V.1996), and revealed usnic acid (minor), salazinic acid (major), consalazinic acid (minor), gyrophoric acid (major), lecanoric acid (trace). The medulla of this specimen is $\mathrm{C}-, \mathrm{KC}+$ rose, and so intermediary between Parmelia delicatula and P. magna.

Unfortunately, apothecia are unknown in both Parmotrema microdactyla and P. flavescens, and so additional differences or similarities could not be compared. At the moment, we place $P$. microdactyla under P. magnum, because of the almost absence of cilia.

Distribution. Known for Brazil, being recorded from Minas Gerais (Lynge 1914, Hale 1960) and Rio de Janeiro (Hale 1960), and Uruguay.

Additional specimens examined. BRAZIL. Bahia: Municipality of Morro do Chapéu, Telebahia Tower, $\sim 6 \mathrm{~km} \mathrm{~S}$ of Morro do Chapéu, elev. $\sim 1000$ m. Campo Rupestre, B.M. Boom \& S.A. Mori 1242 (M); idem, Vale do Rio das Ondas, 5 Km NW of Barreiras, elev. $\sim 600 \mathrm{~m}$., sandstone cliffs and outcrops, on sandstone, 04.III. 1971, H.S. Irwin et al. 31525 (M); idem, 01.V.1961, H. Müller (M). URUGUAY. Rocha: Estancia Siete Cerros, II.1935, C.C. Hosseus 76 (M); idem, 20.III.1935, C.C. 


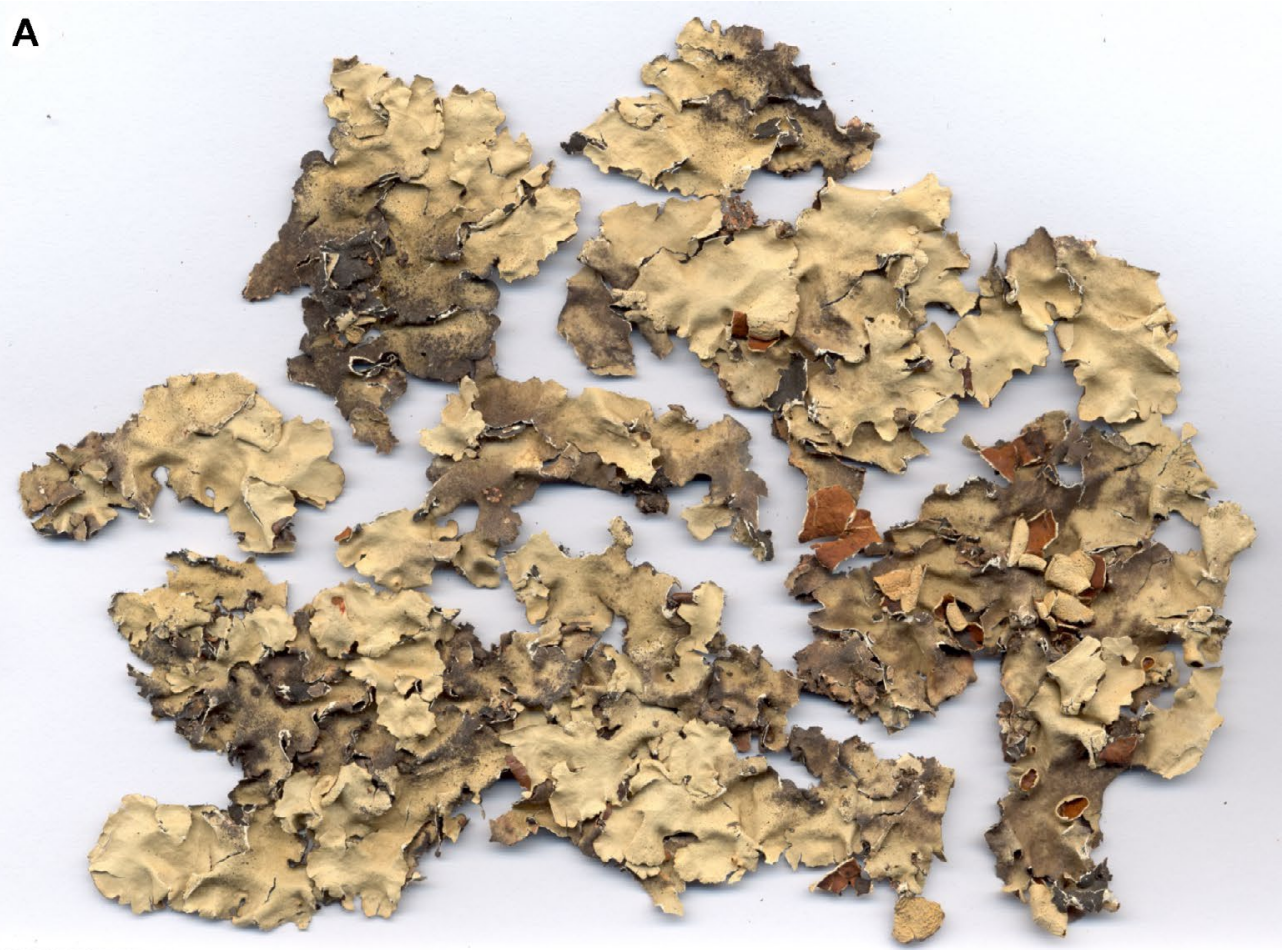

||||||||||||||||||||||||||||||||||||||||||||||||||||||||||||||||||||||||||||||||||||||||||||||||||||||||||||||||||||||||||||||||||||||||||||||||||||+||||||||

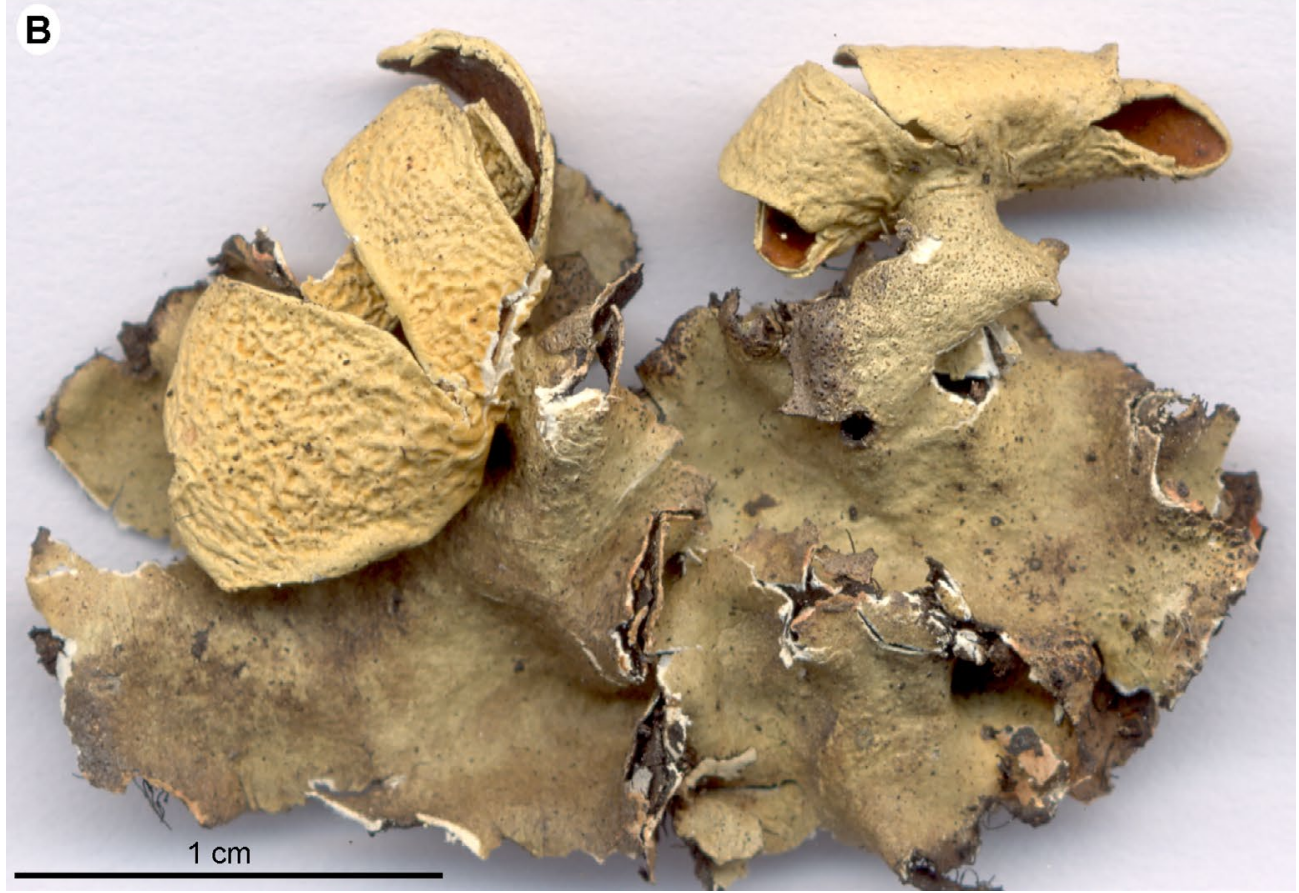

Figure 30. Parmotrema magnum. A - holotype (S); B - isotype (LD), showing the rugose and lacerate apothecia. Scale in milimeters or as indicated.

Hosseus 111 (M). Idem, Maldonado, Punta Ballena, Parque Lussich, $100 \mathrm{~m}$ alt., on sunny stones, 01.V.1961, H.S. Osorio 4608 (UPS).

Parmotrema mantiqueirense Hale, Bibliotheca Lichenologica 38: 113. 1990.

(Fig. 32)

Type: Brazil. Minas Gerais: Serra da Mantiqueira, Oberhalb von Vila Monte Verde, zwischen $1880 \mathrm{~m}$ und der Gipfelregion des Pedra Redonda in 2000 m, 3.VII.1979, K. Kalb s.n. (holotype -Kalb Herbarium; isotype - US!).

Description (based on isotype). Thallus whitish gray, lobate, loosely adnate, over rocks with mosses and plant debris, $11.5 \mathrm{~cm}$ broad. Lobes irregularly branched, laterally overlapped to quite crowded, 7-20 mm wide, surface continuous, smooth, lustrous, becoming irregularly scared and cracked towards the center; apical zone \pm rounded; margin broadly crenate to sublacinulate, undulated. Maculae absent. Cilia black, simple to furcated, up to $2.5 \mathrm{~mm}$ long, often thickened, $0.10-0.15 \mathrm{~mm}$ wide, frequent. Lacinulae, pustules, soredia and isidia absent. Medulla white. Undersurface black, lustrous, smooth, rugulose, papillate or rarely veined, with cracks; marginal zone brown, lustrous, 4-9 mm wide, naked or in part rhizinate, with an attenuated limit, smooth to slightly rugose 
or with rhizinal papillae; rhizines black, simple or rarely furcated, up to $4 \mathrm{~mm}$ long, $0.02-0.1 \mathrm{~mm}$ wide, abundant, evenly distributed.

Apothecia absent [according to Eliasaro (2001), apothecia laminal, adnate, $2-5 \mathrm{~mm}$ in diameter, margin smooth, disc brown, imperforate; ascospores 13-18 × 6-10 $\mu \mathrm{m}]$. Pycnidia laminal or more often submarginal, conspicuous, with or without prominent margin, abundant, ostiole black; conidia filiform, $8-12 \times \sim 1 \mu \mathrm{m}$.

Chemistry. Atranorin (minor), chloroatranorin (trace), salazinic acid (major), consalazinic acid (minor). Cortex $\mathrm{K}+$ yellow, UV-; medulla $\mathrm{K}+$ yellow $\rightarrow$ blood red, $\mathrm{C}-$, $\mathrm{KC}-, \mathrm{P}+$ strong yellow, $\mathrm{UV}-$.
Remarks. Parmotrema mantiqueirense is distinguished by the large, conspicuously ciliate lobes, filiform conidia and the absence of propagules. It is close to P. latissimum, an eciliate species with sublageniform conidia. Apothecia are absent in both holotype (Hale 1990) and isotype (seen here). However, Eliasaro (2001) found one fertile specimen from Paraná, Brazil (see above in the description).

In P. mantiqueirense, some rhizines can occupy part of the marginal zone, mainly in the form of 'rhizinal papillae' (Awasthi 1976) or 'rhizines in development' (Fleig 1997).

Distribution. South America, where it was reported from Brazil (Marcelli 2008). In Brazil, it was recorded from Minas Gerais (Hale 1990; Fleig 1997; Ribeiro 1998),
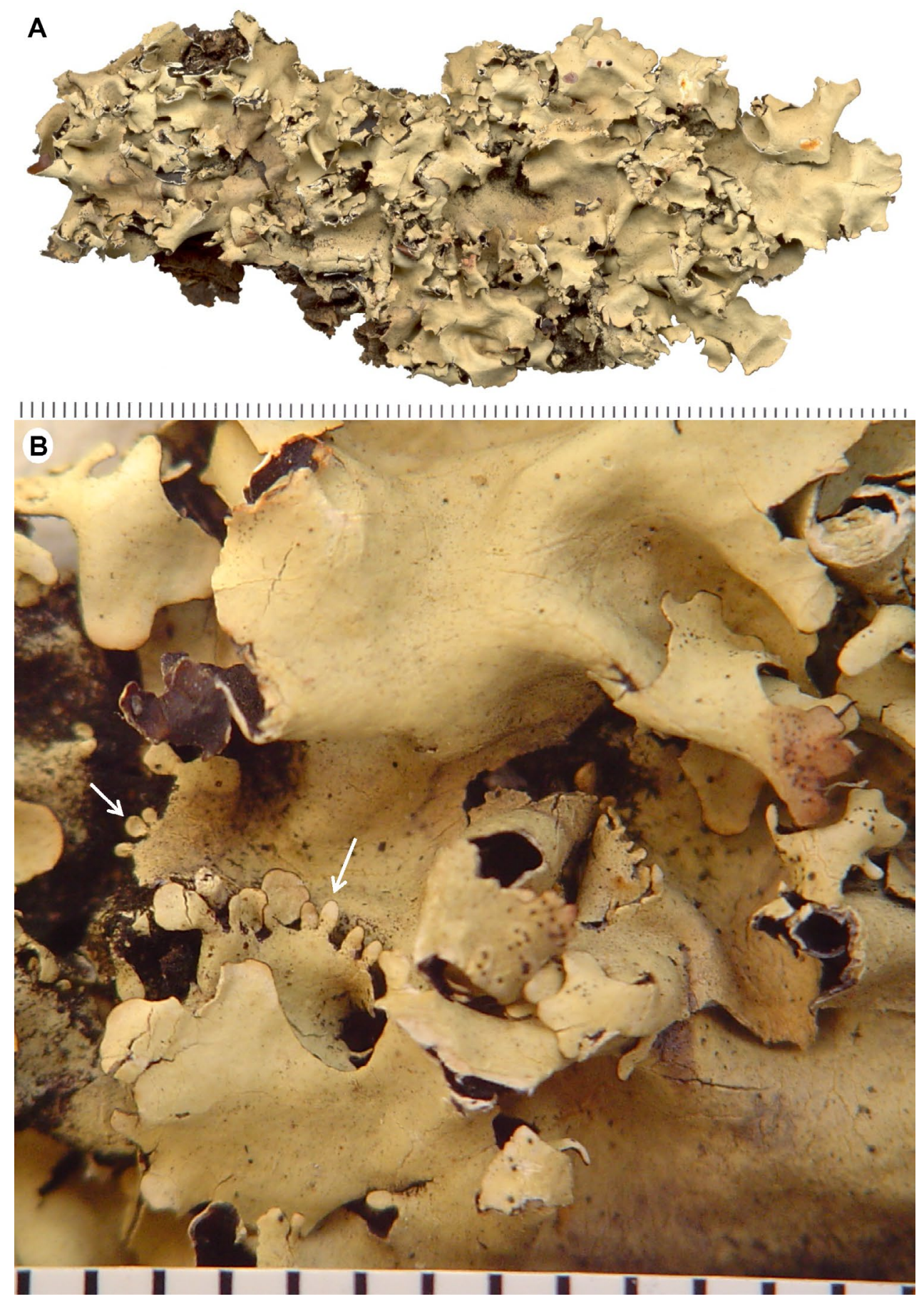

Figure 31. Holotype of Parmelia microdactyla (UPS). A - thallus; B - lobules (arrows). Scales in milimeters. 


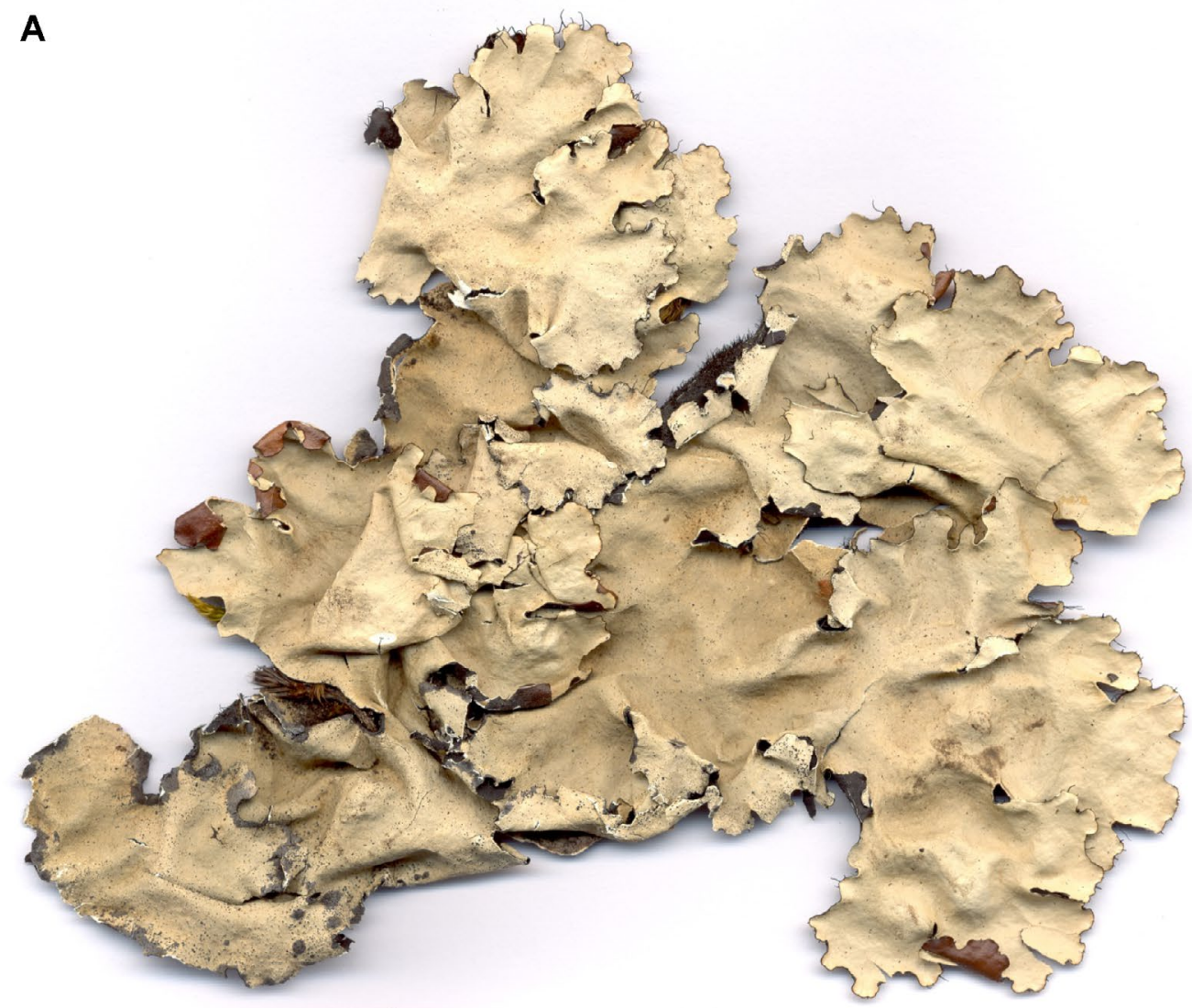

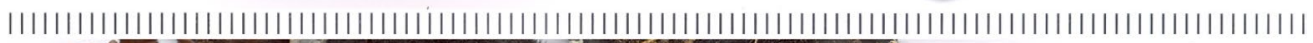

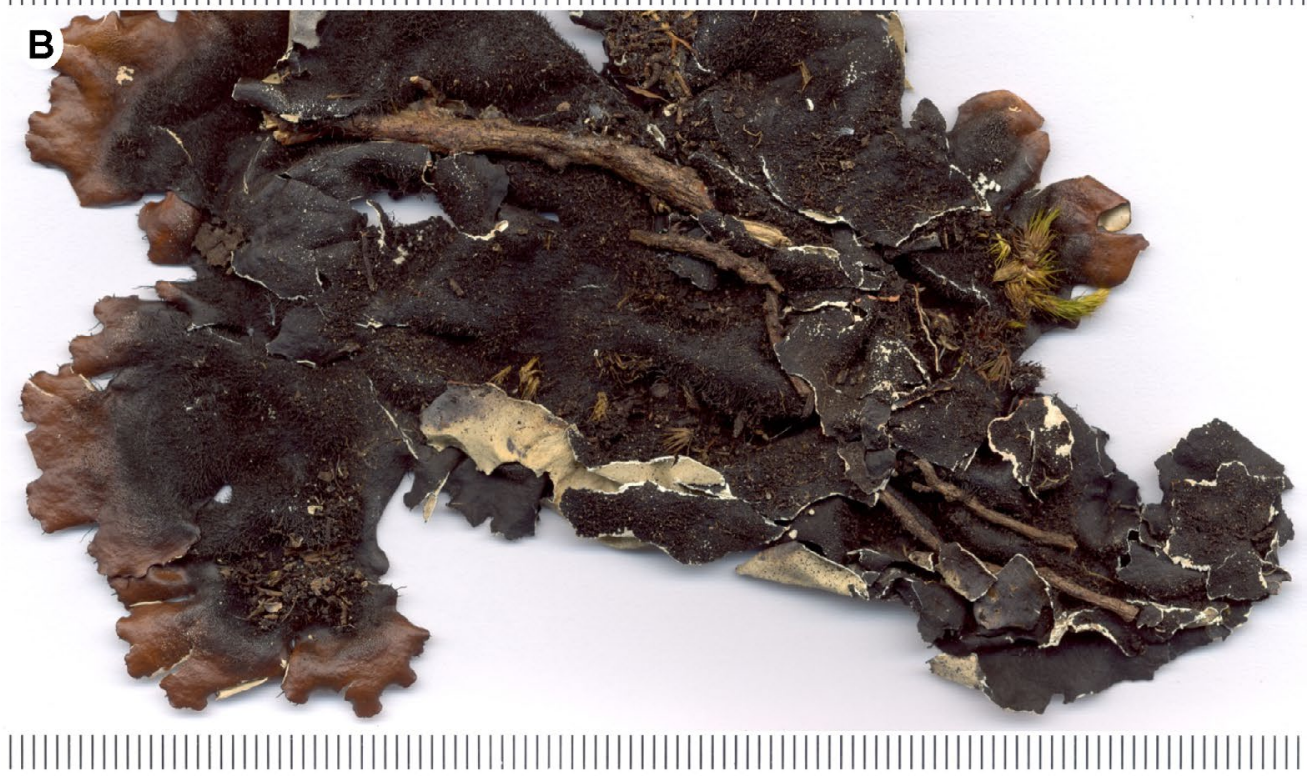

Figure 32. Isotype of Parmotrema mantiqueirense (US). A - upper surface; B - undersurface. Scales in milimeters.

Paraná (Fleig 1997; Eliasaro 2001) and Rio Grande do Sul (Canêz 2005; Spielmann 2005, 2006).

Parmotrema margaritatum (Hue) Hale, Phytologia 28(4): 337. 1974.

(Fig. 33A)

Basionym: Parmelia margaritata Hue, Nouvelles Archives du Muséum d'Histoire Naturelle de Paris ser. 4(1): 193. 1899.

Type: USA Ohio: corticicolous, Sullivant (holotype - PC!).

Description (based on holotype). Thallus brownish (herbarium), sublaciniate, loosely adnate, substrate, 6-17 cm broad. Sublaciniae crowded, 5-15 mm wide, surface continuous, smooth, opaque to sublustrous, becoming cracked towards the center; apical zone lacinulate, undulated and irregular. Maculae effigurate or sometimes punctiform, often joined and covering most of the thallus surface (hypermaculate), and so quite difficult to realize at first sight, laminal, not originating cracks. Cilia black, simple, up to $2 \mathrm{~mm}$ long, usually thickened, 0.04-0.12 mm wide, frequent. Lacinulae abundant, simple, dichotomous or irregularly branched, plane, apex usually acute, sometimes truncate, $2-10 \times 0.5-3 \mathrm{~mm}$. Soralia whitish, orbicular, 
subapical on the lacinulae, which can become involute as the soralia grows and become confluent; soredia farinose to subgranular. Pustules and isidia absent. Medulla white. Undersurface black, lustrous, smooth to slightly rugose or papillate, rarely veined, with abundant cracks; marginal zone dark brown, lustrous, 1-5 mm wide, naked, with an attenuated limit, smooth, slightly rugose or papillate; rhizines black, monomorphic, up to $2.5 \mathrm{~mm}$ long, $0.01-$ $0.4 \mathrm{~mm}$ wide, simple or irregularly branched, especially near the apices, few, distributed in groups.

Apothecia unknown. Pycnidia submarginal to laminal and restricted to the lacinulae, conspicuous, usually with prominent margin, abundant, ostiole black; conidia filiform, $10-15(-18) \times \sim 1 \mu \mathrm{m}$.

Chemistry. Atranorin (minor), chloroatranorin (trace), salazinic acid (major), consalazinic acid (minor). Cortex $\mathrm{K}+$ yellow, UV-; medulla $\mathrm{K}+$ yellow $\rightarrow$ blood red, $\mathrm{C}-$, $\mathrm{KC}-, \mathrm{P}+$ strong yellow, $\mathrm{UV}-$.

Remarks. Parmotrema margaritatum is distinguished by the abundantly lacinulate thallus, the soralia orbicular or confluent growing on the lacinulae, the effigurate maculae usually becoming hypermaculate, the thickened and simple cilia and the black undersurface, with a dark brown and erhizinate marginal zone. Also sorediate, P. petropoliense has pustuloid raised structures that give rise to soredia, long (up to $3 \mathrm{~mm}$ ) and frequently furcated cilia, brown undersurface with dichotomous rhizines and effigurate maculae.

The holotype collection is composed of six thalli. Three of them are glued on a paper, in one sheet (PC 0116176) and three are not glued on another sheet (PC 0116177). Both have full indications of collector, Hue's handwriting, etc., and actually, they are very similar in all features. Hale (1965) illustrated only part of the larger specimen from the sheet PC 0116177 , thus, if a lectotype must be chosen, this is probably the best choice, since the undersurface can also be adequately studied.

Distribution. North America (Hale 1965; Taylor 1967; Brodo et al. 2001; Egan et al. 2016) South America (Feuerer 2008), and Asia (Awasthi 1976; Chen et al. 2005; Divakar \& Upreti 2005). In South America, it was reported from Venezuela (Feuerer 2008) and Brazil. In Brazil it is known from Rio Grande do Sul (Canêz 2005) and Santa Catarina (Gerlach \& Eliasaro 2014a, as Parmotrema aff. margaritatum). Rio Grande do Sul (Canêz 2005).

Parmotrema masonii Ferraro, Hickenia 1(34): 191. 1979.

(Fig. 33B)

Type: Argentina. Corrientes: Depto. Concepción, Paso Crucecita, 20-VI-1974, L.I. Ferraro 215 (holotype - CTES!; isotype - US!; paratype - CTES!).

Description (based on holotype). Thallus yellowish, lobate, loosely adnate, corticicolous, $10 \mathrm{~cm}$ broad. Lobes irregularly branched, laterally overlapped, 2-10 mm wide, surface continuous, smooth, opaque, becoming strongly rugose and cracked towards the center; apical zone rounded; margin crenate, sometimes with deep sinuses, undulated. Maculae indistinct, punctiform, laminal. Cilia black, simple, usually tapering and turning upwards, up to $0.7 \mathrm{~mm}$ long, $0.05-0.1 \mathrm{~mm}$ wide, frequent. Lacinulae, pustules, soredia and isidia absent. Medulla white. Undersurface black, sublustrous, smooth, rugose, papillate, with cracks; marginal zone dark brown, sublustrous, 1-2.5 mm wide, naked, with an attenuated limit, smooth, rugose or papillate; rhizines black, simple or rarely branched, up to $1.5 \mathrm{~mm}$ long, $0.02-0.05(-0.1) \mathrm{mm}$ wide, abundant, \pm evenly distributed.

Apothecia cupuliform, $0.5-5.5 \mathrm{~mm}$ in diameter, short-stipitate, usually submarginal, margin crenate, frequently involute, amphithecium smooth to irregular or rugose, pruinose, disc brown, slightly pruinose, imperforate; ascospores ellipsoid to ovoid, 15-16.5 × 7.5-8 $\mu \mathrm{m}$, episporium $\sim 1 \mu \mathrm{m}$. Pycnidia submarginal, conspicuous, with or without prominent margin, abundant, ostiole black; conidia filiform, 7-12 $\times \sim 1 \mu \mathrm{m}$.

Chemistry. Usnic acid (minor), salazinic acid (major), consalazinic acid (minor), hypoconstictic acid (minor). Cortex $\mathrm{K}+$ yellowish, $\mathrm{UV}-$; medulla $\mathrm{K}+$ yellow $\rightarrow$ blood red, $\mathrm{C}-, \mathrm{KC}-, \mathrm{P}+$ strong yellow, $\mathrm{UV}-$.

Remarks. Parmotrema masonii is characterized by the short cilia (up to $0.7 \mathrm{~mm}$ ), the presence of salazinic and hypoconstictic acid and the absence of vegetative propagules. Related species include $P$. delicatulum (longer cilia and with different chemistry), P. flavescens (isidiate), P. mirandum, $P$. nylanderi and $P$. pectinatum (sorediate).

The holotype of $P$. masonii has the upper surface strongly rugose (resembling that of $P$. madylinae), short and tapering cilia. The isotype agrees very well with the holotype, except that it has slightly shorter ascospores 13.5-15 $\mu \mathrm{m}$ long and apothecia frequently irregularly 'coronate' with black dots, probably formed by some parasitic fungus. The paratype received from CTES presents several differences between the holotype and isotype: 1) larger, lacerate apothecia (up to $8 \mathrm{~mm}$ in diameter); 2) smaller ascospores, $10-12.5 \times 6-7.5 \mu \mathrm{m}$, episporium $0.5-1 \mu \mathrm{m} ; 3)$ upper surface only slightly rugose and 4) cilia usually thinner and longer (up to $1.5 \mathrm{~mm}$ ). Nevertheless, the conidia and overall morphology are similar.

The specimen from São Paulo (Marcelli \& Barbosa 35720) shares the same chemistry of $P$. masonii, but also has thinner and longer cilia (up to $1.5 \mathrm{~mm}$ ) and the upper surface is only slightly rugose. It does not produce apothecia, but the conidia data (filiform, $8-11 \times \sim 1 \mu \mathrm{m}$ according to a label from P. Jungbluth dated 2005) agree roughly with the measurements from the holotype. Since we did not have access to a rich collection of this species, it is premature to assign these differences to different taxa by the time.

Distribution. South America, where it was recorded from Bolivia (Kukwa et al. 2012), Argentina (Ferraro 1979), Brazil (Fleig 1997) and Paraguay (Fleig 1997). In Brazil, it is known from Rio Grande do Sul (Fleig 1997) and São Paulo (Jungbluth 2006). 


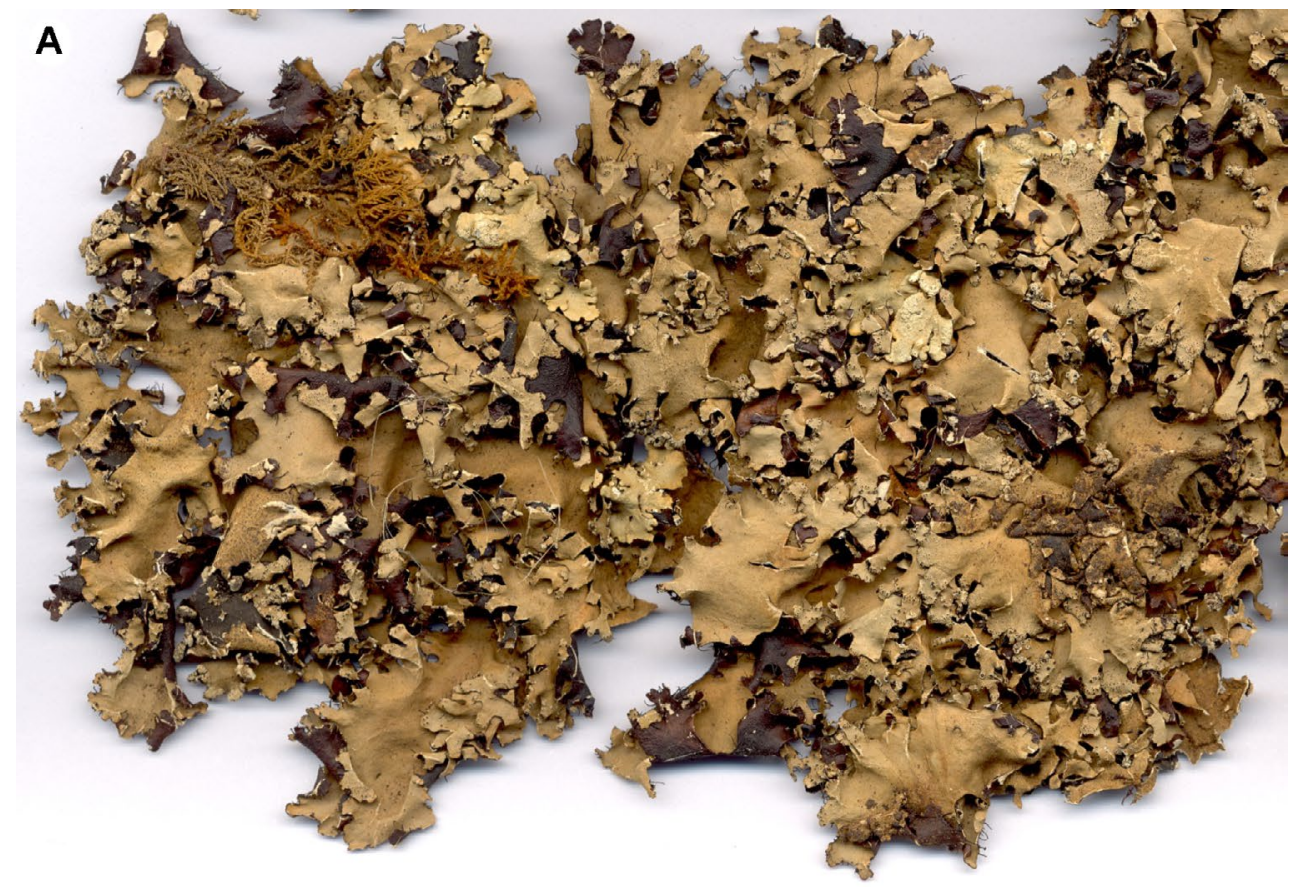

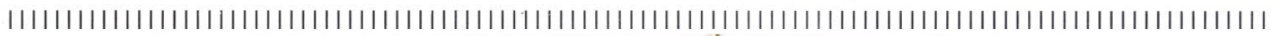

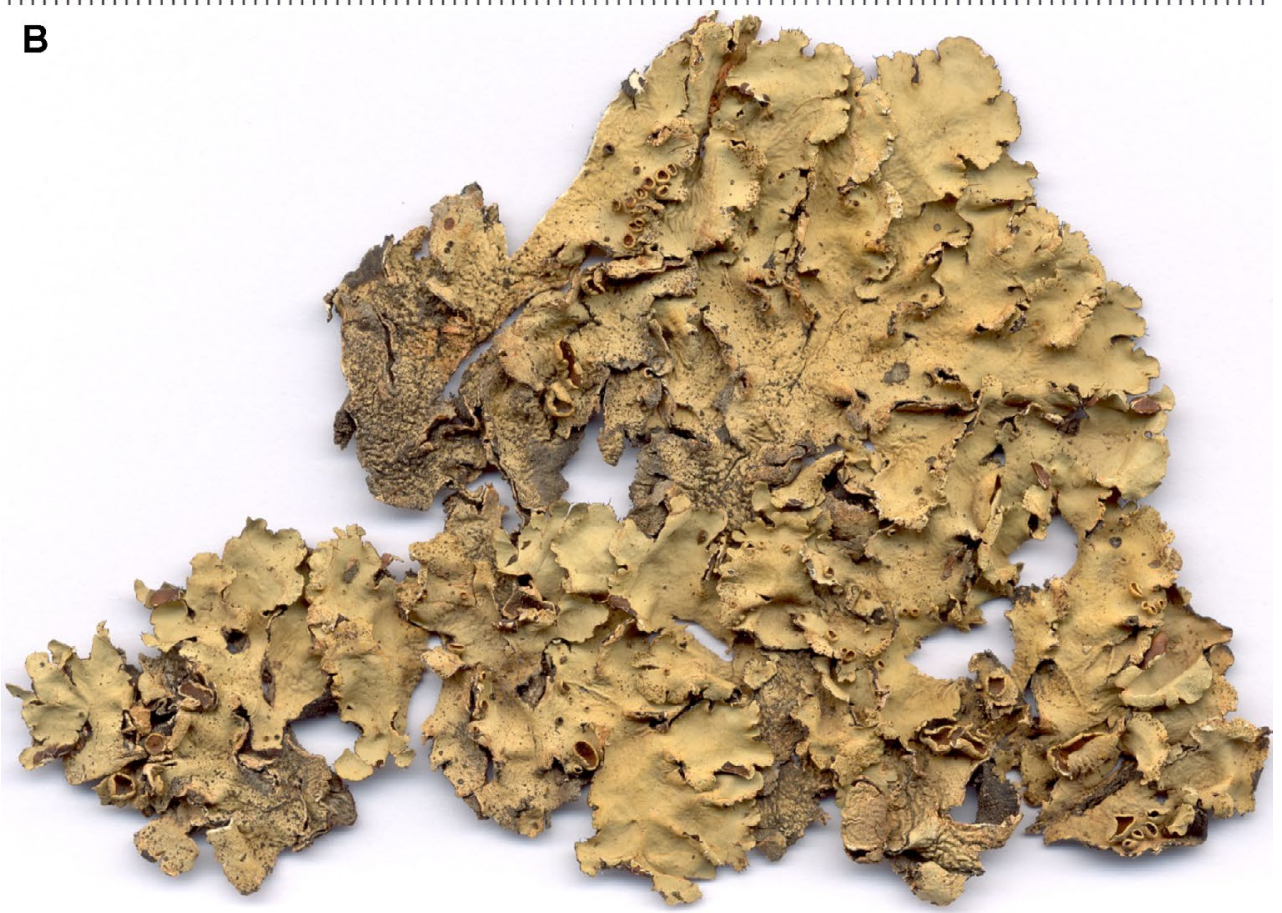

IIIIIIIIIIIIIIIIIIIIIIIIIIIIIIIIIIIIIIIIIIIIIIIIIIIIIIIIIIIIIIIIIIIIIIIIIIIIIIIIIIIIIII

Figure 33. A - part of the holotype of Parmotrema margaritatum (PC); B - holotype of Parmotrema masonii (CTES). Scales in milimeters.

Additional specimens examined. ARGENTINA. Corrientes: Depto. Concepción, Paso Crucecita, on Sapium sp. (Euphorbiaceae), 20-VI-1974, L.I. Ferraro 206 (CTES-78596). BRAZIL. São Paulo: Municipality of São Manuel, Fazenda Palmeira da Serra, private cerrado protected area, on tree trunk in the woods edge, 03.VI.2003, M.P. Marcelli \& S.B. Barbosa 35720 (SP).

Parmotrema maximum (Hue) Spielmann \& Marcelli, comb. nov.

(Fig. 34A)

MycoBank MB 838189

Basionym: Parmelia maxima Hue, Nouvelles Archives du Muséum d'Histoire Naturelle de Paris, ser. 4(1): 193. 1899.
Type: Mexico. Chimaleapan: Cerro de Santiago, near Lerma, apparently saxicolous, 26.VI.1890, Maury 3318 (holotype PC!).

Description (based on holotype). Thallus brownish (herbarium), lobate, loosely adnate, probably saxicolous, $13.5-17 \mathrm{~cm}$ broad. Lobes irregularly branched, laterally overlapped to \pm crowded, $0.5-25 \mathrm{~mm}$ wide, surface continuous, smooth or with rounded tiny depressions, lustrous, becoming irregularly cracked towards the center; apical zone rounded; margin broadly crenate to lacinulate, undulated to sinuous. Maculae absent or irregular and conspicuous in some lobes. Cilia black, simple to furcated or 
dichotomous, up to $2.5 \mathrm{~mm}$ long, usually thickened, 0.04 $0.1 \mathrm{~mm}$ wide, frequent. Lacinulae simple to dichotomous, plane, apex usually rounded, sometimes truncate or acute, up to $5 \mathrm{~mm}$ long, $0.5-5 \mathrm{~mm}$ wide. Pustules and isidia absent. Soralia linear continuous or sometimes growing backwards or becoming labriform, marginal and on the lacinulae apices; soredia farinose to granular. Medulla white. Undersurface black, lustrous, smooth to rugose or papillate; marginal zone absent (black) or brown to dark brown, lustrous, 2-6 mm wide, naked, with an attenuated limit, smooth, slightly rugose or papillate, with cracks; rhizines black, usually simple, less frequently irregularly branched, up to 3(-4) mm long, 0.01-0.1(-0.2) mm wide, abundant, irregularly distributed.
Apothecia plane (pressed down), 1-2.3 cm in diameter, apparently substipitate, margin smooth to incised or lacerate, amphithecium maculate, with irregular depressions or rugose, disc dark brown, epruinose, perforate or not; ascospores ellipsoid, 12.5-15 × 7-9 $\mu \mathrm{m}$, episporium $\sim 1 \mu \mathrm{m}$. Pycnidia submarginal, little conspicuous, without prominent margin, few, ostiole black; conidia short-filiform, $7-10 \times \sim 1 \mu \mathrm{m}$.

Chemistry. Atranorin (minor), chloroatranorin (trace), salazinic acid (major), consalazinic acid (minor). Cortex $\mathrm{K}+$ yellow, $\mathrm{UV}-$; medulla $\mathrm{K}+$ yellow $\rightarrow$ blood red, $\mathrm{C}-$, $\mathrm{KC}-, \mathrm{P}+$ strong yellow, $\mathrm{UV}-$.
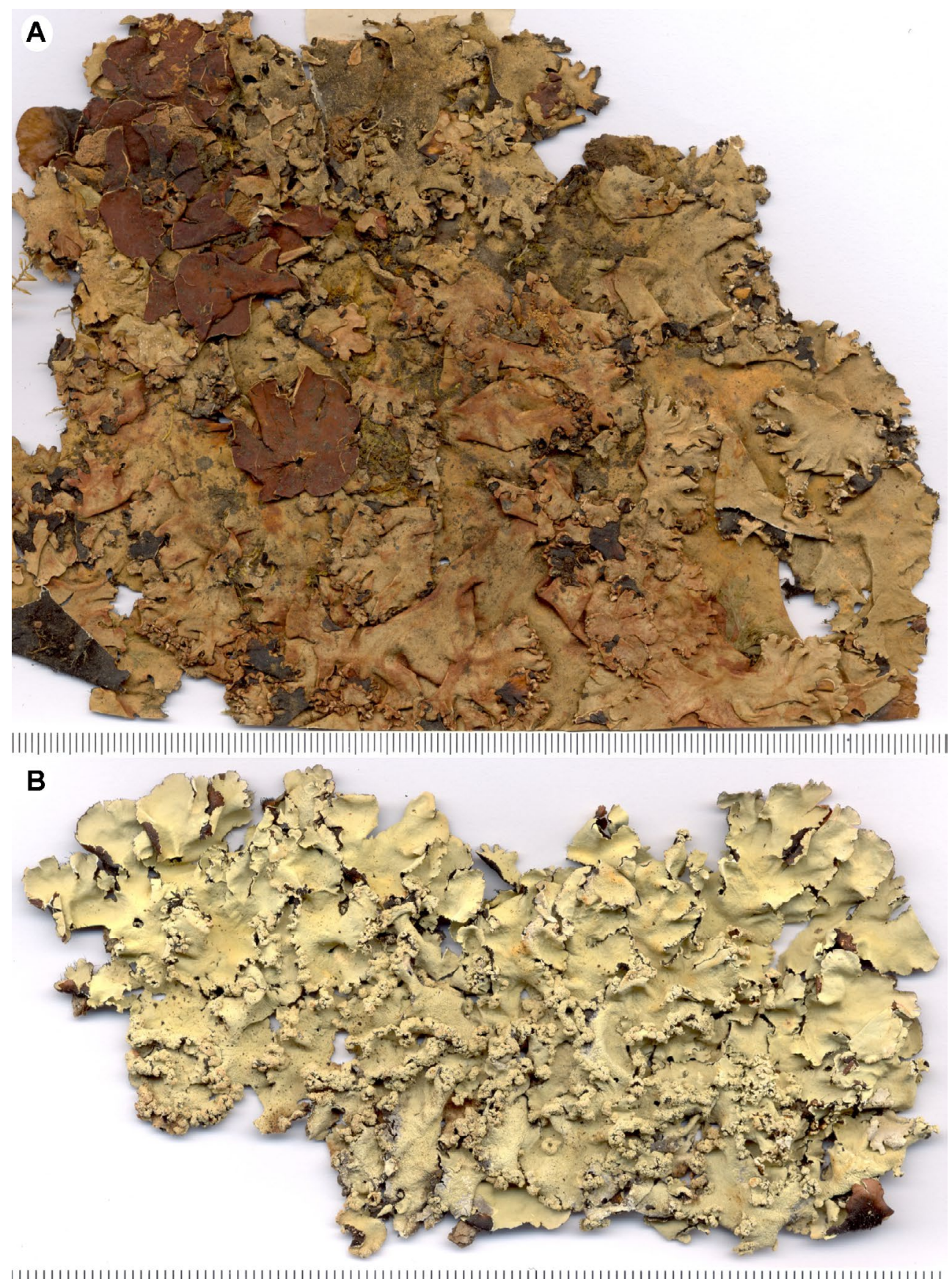

Figure 34. A - holotype of Parmotrema maximum (PC); B - holotype of Parmotrema mirandum (US). Scales in milimeters. 
Remarks. Parmotrema maximum is characterized by the presence of marginal soralia, also occurring at the apices of the lacinulae, the broad nude under margin, the size of ascospores and the short-filiform conidia. This species was up to now included in the synonymy of $P$. stuppeum, which however does not develop lacinulae and additionally has sublageniform conidia (Nash \& Elix 2002b). More similar morphologically is $P$. margaritatum (see Hue 1899; Hale 1979), however, distinct by the effigurate maculae.

The holotype is composed of two thalli, one of them bearing several apothecia and labeled ' 32 '. The second thallus is quite similar to the first; however, no apothecia are present, and it is not part of the first thallus. Morphologically and chemically both thalli are similar.

Distribution. Mexico (Hue 1899).

Parmotrema mirandum (Hale) Hale, Phytologia 28(4): 337. 1974.

(Fig. 34B)

Basionym: Parmelia miranda Hale, Contributions from the United States National Herbarium 36(5): 273. 1965.

Type: Mexico. Oaxaca: northwest of Tehuantepec, Km 686 on highway 190, Pine-scrub oak mountainside, on deciduous trees, elev. 1160 m, 31.III.1960, M.E. Hale \& T.R. Soderstrom 20653 (holotype - US!; isotypes - COLO!, DUKE!, LISU, MSC!, REN, S!, TNS!).

Description (based on holotype). Thallus yellowish, lobate, \pm adnate, corticicolous, $5.5-11 \mathrm{~cm}$ broad. Lobes irregularly branched, laterally overlapped to \pm crowded in the center, 4-9 mm wide, surface continuous, smooth to slightly scrobiculate or rugose, opaque, becoming irregularly cracked in some areas; apical zone rounded, often pruinose; margin broadly crenate, sometimes more incised, undulated. Maculae inconspicuous, irregular. Cilia black, simple or rarely furcated, $0.2-1(-1.5) \times$ $0.03-0.05 \mathrm{~mm}$, frequent. Soralia marginal and usually extensive, also in the apices of the sublacinulae, turning the lobe apices involute; soredia subgranular. Lacinulae, pustules and isidia absent. Medulla white or with red stains in some areas (salazinic acid in decomposition). Undersurface black, lustrous, rugose, papillate or rarely veined, with cracks; marginal zone brown or sometimes pale brown or with beige stains, lustrous, 1-4 mm wide, naked, with a sharp limit, smooth, rugose or papillate; rhizines black, simple, $0.2-1.5 \times 0.01-0.05 \mathrm{~mm}$, abundant, evenly distributed in the distal parts, but absent in large areas at the center.

Apothecia unknown. Pycnidia (from the MSC isotype) submarginal, conspicuous, with prominent margin, rare, ostiole black; conidia short-filiform, 6-9 $\times \sim 1 \mu \mathrm{m}$.

Chemistry. Usnic acid (minor), salazinic acid (major), consalazinic acid (minor), hypoconstictic acid (minor). Cortex $\mathrm{K}+$ yellow, UV-; medulla $\mathrm{K}+$ yellow $\rightarrow$ blood red, $\mathrm{C}-, \mathrm{KC}-, \mathrm{P}+$ strong yellow, $\mathrm{UV}-$.

Remarks. Parmotrema mirandum is recognized by the yellowish (usnic acid) sorediate thallus with salazinic acid and hypoconstictic acid. The discovery of hypoconstictic acid in this species places it close to Parmotrema masonii, suggesting it as the sorediate pair.

The holotype consists of three well-developed thalli, and by the great abundance of isotypes (some with two or three thalli), one can assume that the species was quite abundant in the type locality.

About 20 supposed pycnidia (it is difficult to prove if they will produce conidia or not, since they are actually only black dots on the surface, and under the microscope, no particular structure can be seen) were examined from the holotype; however, no conidia were found. Only one 'true' pycnidium was found in the isotype from MSC, from where the measurements were obtained.

The examined isotypes are similar in the overall morphology to the holotype; however, some particularities can be pointed out: the isotype from TNS has more distinct beige marginal zones on the undersurface, and they seem to be clearly associated with the lobes that produce soralia. The same is true for the isotype from MSC, which additionally has wider lobes, up to $14 \mathrm{~mm}$ wide. Large lobes (equally up to $14 \mathrm{~mm}$ ) were found in the isotype from S. Finally, the isotype from DUKE develops some strongly rugose pustulate-like areas in the thallus center.

Distribution. North America (Hale 1965; Egan et al. 2016), and South America, where it was recorded from Venezuela (Feuerer 2008), Bolivia (Kukwa et al. 2012) and Brazil (Feuerer 2008). In Brazil, it is known from Minas Gerais (Ribeiro 1998), Paraná (Eliasaro 2001), Pernambuco (Buril 2015) and São Paulo (Ribeiro 1998).

Additional specimens examined. MEXICO. Chiapas: $2 \mathrm{Km}$ North of highway 190 on road to Pueblo Nuevo, West of Chiapas, $1070 \mathrm{~m}$, pine pasture, on deciduous trees, 23 March 1960, M.E. Hale \& T.R. Soderstrom 20165 (US). Chiapas: 8 Km East of Teopisca on highway 190, $2020 \mathrm{~m}$, open pine-oak pasture, on deciduous trees, 24 March 1960, M.E. Hale \& T.R. Soderstrom 20346 (US).

Parmotrema neotropicum Kurok., Mycotaxon 5(2): 437. 1977

Type: Mexico. Chiapas: Pine-oak forest on mountainside, 2120 m alt., Km. 1145 on highway 190, west of San Cristóbal, on conifers, 25.III.1960, M.E. Hale \& T.R. Soderstrom 20190 (holotype - US!).

$\equiv$ Rimeliella neotropica (Kurok.) Kurok., Annals of the Tsukuba Botanical Garden 10: 6. 1991.

$\equiv$ Canomaculina neotropica (Kurok.) Elix, Mycotaxon 65: 477. 1997.

Description (based on holotype). Thallus buff yellowish, lobate, adnate to loosely adnate, corticicolous, $9.5 \mathrm{~cm}$ broad. Lobes irregularly branched, \pm crowded, $3-12 \mathrm{~mm}$ wide, surface continuous, with rounded depressions or cracked, smooth, sublustrous, becoming rugose and cracked in the center; apical zone rounded; margin crenate-incised, undulated. Maculae weak, effigurate, laminal, not originating cracks. Cilia black, simple or rarely furcated, up to $1.2 \mathrm{~mm}$ long, $0.02-0.1 \mathrm{~mm}$ wide, few. Isidia concolor to the thallus or paler, apex usually dark brown, simple to coralloid, up to $1 \mathrm{~mm}$ high, $0.05-0.5 \mathrm{~mm}$ wide, 

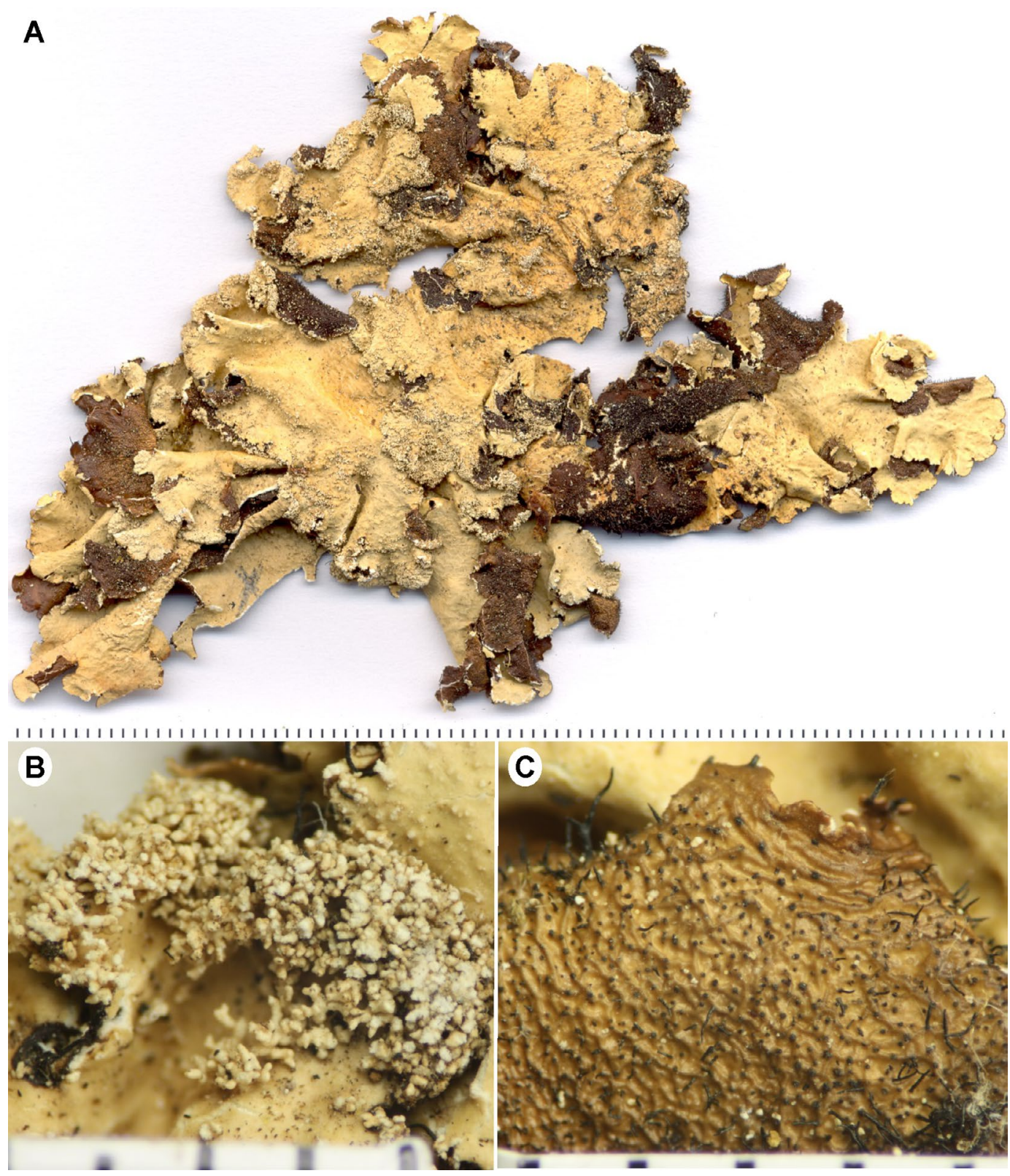

Figure 35. Holotype of Parmotrema neotropicum (US). A - thallus; B - isidia; C - undersurface. Scales in milimeters.

erect, firm or breaking into soredioid granules, sometimes with lateral cilia, laminal or more usually submarginal to marginal. Lacinulae, pustules and soredia absent. Medulla white. Undersurface dark brown to brown, lustrous or opaque, abundantly veined, without cracks; marginal zone absent; rhizines black, dimorphic, the shorter ones simple and usually curled, up to $1 \mathrm{~mm}$ long, $0.01-0.05 \mathrm{~mm}$ wide, abundant, evenly distributed; the longer ones up to $4 \mathrm{~mm}$ long, $0.05-0.15 \mathrm{~mm}$, usually irregularly branched, especially near the apex, few, distributed in groups.

Apothecia unknown. Pycnidia submarginal, conspicuous, without prominent margin, rare, ostiole black; conidia filiform, 7-11 $\times \sim 1 \mu \mathrm{m}$.

Chemistry. Atranorin (minor), chloroatranorin (trace), usnic acid (minor), isousnic acid (minor), salazinic acid (major), consalazinic acid (minor). Cortex $\mathrm{K}+$ yellow, $\mathrm{UV}-$; medulla $\mathrm{K}+$ yellow $\rightarrow$ blood red, $\mathrm{C}-$, $\mathrm{KC}-$, $\mathrm{P}+$ strong yellow, UV-.
Remarks. Parmotrema neotropicum is distinguished by the isidiate thallus, the isidia sometimes breaking up in soredioid granules, the effigurate maculae, the abundantly veined, brown undersurface with dimorphic rhizines and the presence of usnic acid. It can be confused with $P$. subtinctorium, but in this species the isidia remain entire, the undersurface is only slightly rugose to papillate, the usnic acid is absent, and it produces norlobaridone in the medulla.

The holotype is composed of two distinct thalli (i.e., not parts of the same thallus) that agree with each other in all relevant features.

Distribution. USA, Mexico, Cuba (Hale 1977; Kurokawa 1991; Egan et al. 2016). In South America, it was recorded from Venezuela (López-Figueiras 1986) Bolivia (Kukwa et al. 2012) and Brazil (Marcelli 2008). In Brazil, it was reported from Goiás (Kurokawa 1991), Minas Gerais (Ribeiro 1998), Paraná (Donha 2005), Pernambuco, 
Rio de Janeiro (Kurokawa 1991), Rio Grande do Sul (Fleig 1997) and São Paulo (Marcelli 1992; Marcelli \& Benatti 2008).

Additional specimens examined. VENEZUELA. Lara: Sierra Portuguesa, El Vigia, cercanías de Villa Nueva, en cafetales, 1100 m, corticicolous, 30 March 1979, M. López Figueiras \& M. E. Hale 19825 (US). Táchira: Vía Villa Paez-Betania, valley of Páramo de Tama, open rocky pastures, 2000-2300 m, 25 March 1975, M.E. Hale \& M. López Figueiras 45142 (US).

Parmotrema nudum (Hue) Spielmann \& Marcelli, comb. et stat. nov.

(Fig. 36A)

MycoBank MB 838190
Basionym: Parmelia reticulata f. nuda Hue, Nouvelles Archives du Muséum d'Histoire Naturelle de Paris, sér. 4(1): 177, plate V, fig. 2.

Type: Uruguay. Prope Montevideo, Cerro Melones, saxicolous, 1875 and 1876, Fruchart s.n. (lectotype - PC!).

Description (based on lectotype). Thallus brownish, sublaciniate, apparently loosely adnate, saxicolous, 6-11 cm broad; sublaciniae irregularly branched, crowded, (1-) 2-6 mm wide, surface continuous, reticulate, irregularly cracked towards the center, smooth to strongly rugose and forming pustules; apical zone truncate or slightly rounded, sometimes acute; margin usually broadly sinuous, plane to undulated. Maculae distinct, reticulate, laminal, originating cracks that take part in the formation

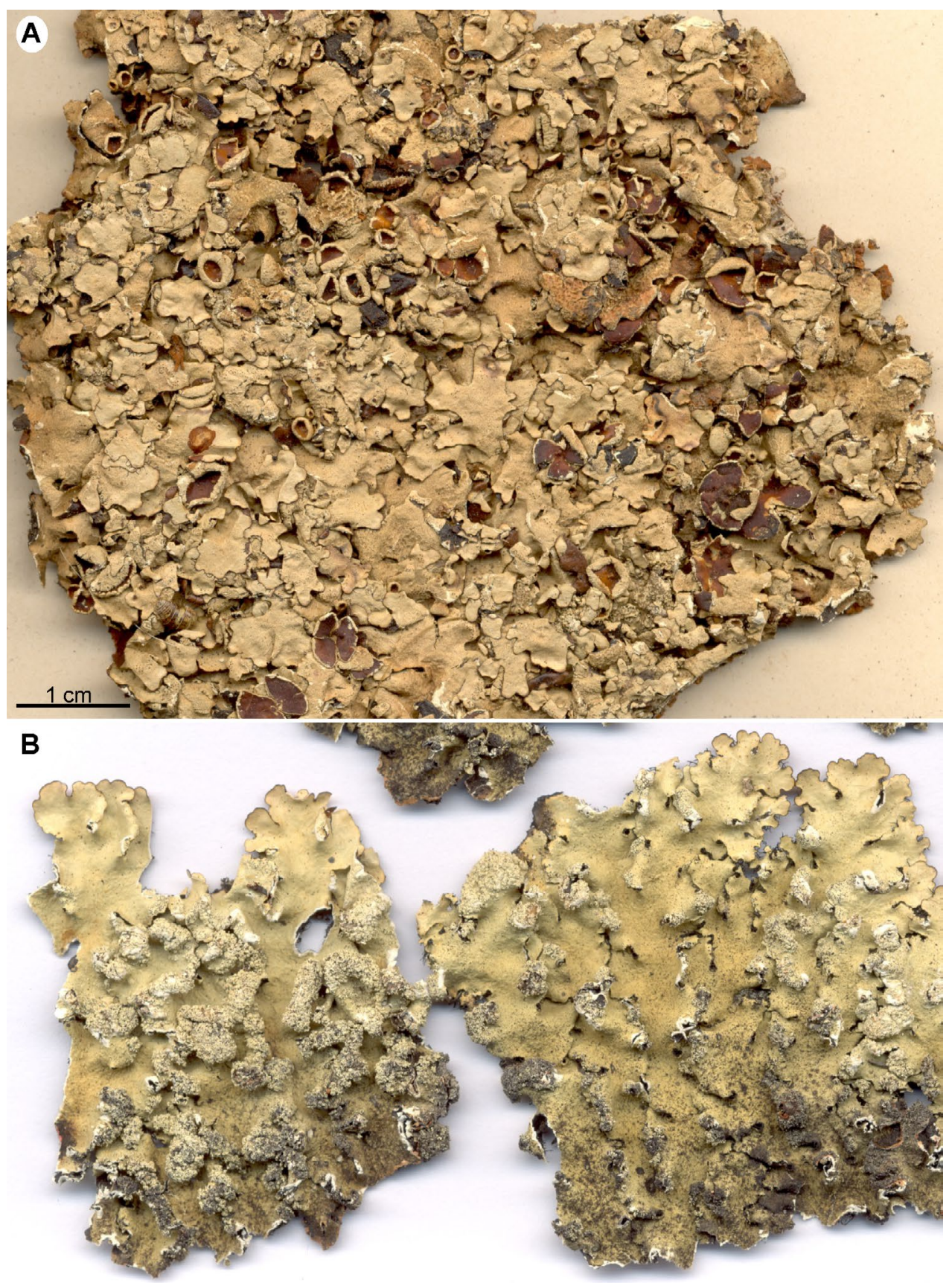

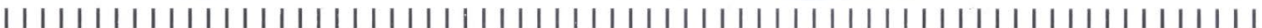

Figure 36. A - lectotype of Parmotrema nudum (PC); B - holotype of Parmotrema nylanderi (S). Scales in milimeters or as indicated. 
of the pustules; Cilia black, simple, 0.2-0.9 mm, abundant. Pustules rugose to shapeless, laminal, remaining entire, often formed in the areolae contact. Lacinulae, soredia and isidia absent. Isidia absent. Medulla white. Undersurface not well studied [thallus pasted in a paper card, description based on just a small part of one thallus], lustrous, smooth to rugose, with cracks; marginal zone dark brown, lustrous, up to $4 \mathrm{~mm}$ wide, rhizinate, with an attenuated limit, smooth or papillate; rhizines black, usually simple, up to $1 \mathrm{~mm}$ long, $0.01-0.05 \mathrm{~mm}$ wide, abundant, more or less evenly distributed.

Apothecia sometimes plane (probably pressed down) to more commonly concave, cupuliform or urceolate, up to $7 \mathrm{~mm}$ in diameter, substipitate, laminal, margin smooth to strongly pustulate, sometimes lacerate, amphithecium strongly maculate near the border, smooth, rugose (at times strongly) or pustulate, disc dark to light brown, epruinose, imperforate or rarely perforate at maturity; ascospores ellipsoid to oblong, $12-14 \times 7.5-9 \mu \mathrm{m}$, episporium $\sim 1 \mu \mathrm{m}$. Pycnidia mainly submarginal, conspicuous, usually with prominent margin, abundant, ostiole black; conidia filiform 9-12.5 $\times \sim 1 \mu \mathrm{m}$.

Chemistry. Atranorin (minor), chloroatranorin (trace), salazinic acid (major), consalazinic acid (minor). Cortex $\mathrm{K}+$ yellow, UV-; medulla $\mathrm{K}+$ yellow $\rightarrow$ blood red, $\mathrm{C}-$, $\mathrm{KC}-, \mathrm{P}+$ strong yellow, $\mathrm{UV}-$.

Remarks. Parmotrema nudum can be distinguished by the reticulate maculae and laminal pustules. This species was up to now considered a synonym of $P$. reticulatum (Hale $\&$ Fletcher 1990). However, the pustular upper surface and absence of soredia are sufficient features to distinguish these two species easily. It can be more properly compared to $P$. granulare, which has abundant lacinulae, but produces soredia, and $P$. ruminatum, an eciliate species where the pustules sometimes flake off the areolae.

The lectotype is well-preserved and developed, although glued to a paper, so that the underside could not be completely described.

Distribution. Uruguay (Hue 1899).

Parmotrema nylanderi (Lynge) Hale, Smithsonian Contributions to Botany 33: 54. 1976.

(Fig. 36B)

Basionym: Parmelia nylanderi Lynge, Arkiv för Botanik 13(13): 82. 1914.

Type: Brazil. Mato Grosso: Serra da Chapada [nowadays Chapada dos Guimarães], near São Jeronymo, supra rupes apricas, 03.VI.1894, G.O.A. Malme 2747 (holotype - S!).

$\equiv$ Parmelina nylanderi (Lynge) Hale, Phytologia 28(5): 483. 1974.

Description (based on holotype). Thallus yellowish, lobate, loosely adnate, saxicolous, 6-7.5 cm broad. Lobes irregularly branched, laterally overlapped, $1-4.5 \mathrm{~mm}$ wide, surface continuous or cracked, smooth, lustrous in the young regions, becoming dull rugose and cracked towards the center; apical zone rounded; margin crenate, marked by a distinct black line, sometimes sublacinulate, undulated. Maculae absent. Cilia black, simple or rarely bifurcated near the apex, usually short, and sometimes thickened, $0.2-1(-1.5) \times 0.05-0.1 \mathrm{~mm}$, frequent, although in some lobes totally absent. Pustules rugose or orbicular, or multiform, submarginal extensive, usually arranged in groups and advancing over the lamina, originating granular soredia. Lacinulae and isidia absent. Medulla white. Undersurface black, lustrous, smooth or rarely rugose, with cracks; marginal zone brown, lustrous, 1-2 mm wide, naked, with a sharp or attenuated limit, usually smooth, less frequently slightly rugose or papillate; rhizines black, simple, furcated or less frequently dichotomous, up to $2 \mathrm{~mm}$ long, thin to thickened, $0.02-0.1 \mathrm{~mm}$ wide, abundant, irregularly distributed.

Apothecia unknown. Pycnidia submarginal, inconspicuous, without prominent margin, few, ostiole black, immature; conidia not found ( 20 pycnidia examined).

Chemistry. Usnic acid (minor), salazinic acid (major), consalazinic acid (minor), hypoconstictic acid (minor), gyrophoric acid (minor). Cortex $\mathrm{K}-$, UV-; medulla $\mathrm{K}+$ yellow $\rightarrow$ blood red, $\mathrm{C}+$ rose, $\mathrm{KC}+$ reddish rose, $\mathrm{P}+$ strong yellow, UV-.

Remarks. Parmotrema nylanderi is distinguished by the lobate yellowish thallus (usnic acid), the presence of salazinic acid and gyrophoric acid in the medulla $(\mathrm{K}+$ yellow $\rightarrow$ red, $\mathrm{C}+$ rose), and the production of pustules. Another close species, which also produces pustular soredia, is Parmotrema pectinatum. It differs by the laciniate thallus with narrow laciniae $(0.8-3 \mathrm{~mm})$ copiously ciliate at the margins. Apothecia and conidia are unknown, however, and since they are also unknown in $P$. nylanderi, further collections are necessary to establish more concretely the similarities of these two species. Other species with salazinic acid and usnic acid do not have gyrophoric acid: P. mirandum (sorediate), P. delicatulum and P. masonii (without propagules) and $P$. flavescens (isidiate).

The holotype of $P$. nylanderi is constituted by four pieces, and could well be part of the same thallus. In the protologue (Lynge 1914), the thallus size is 6-7 cm. Nevertheless, this lichen was collected by Malme several years earlier, in 1894, and could well have cracked before the description.

Although Hale (1960) first defined the specimen Malme 2747 as holotype, later on (Hale 1976) he considered it to be a lectotype. However, since it is the only specimen recorded in the protologue (Lynge 1914), and as apparently there are no additional types, it must be categorized as holotype, according to the Article 9.1 Note 1 of the Shenzhen Code (Turland et al. 2017).

Distribution. Known only from Bolivia (Kukwa et al. 2012) and Brazil, where it was recorded from Minas Gerais (Ribeiro 1998), Mato Grosso (Lynge 1914; Hale 1960), Pernambuco (Buril 2015) and São Paulo (Hale 1976; Jungbluth 2006). The record from Ribeiro (1998) needs to be investigated, since it has negative thallus reactions (Jungbluth 2006). 
Parmotrema parahypotropum (W.L. Culb.) Hale, Phytologia 28(4): 338. 1974.

(Fig. 37)

Basionym: Parmelia parahypotropa W.L. Culb., The Bryologist 76(1): 29. 1973.

Type: Taiwan (Formosa). Kural: $250 \mathrm{~m}$ alt., 01.II.1964, Kurokawa 1487 (holotype - TNS!, isotype - DUKE!).

Description (based on holotype). Thallus pale brownish (herbarium), sublaciniate?, extensively lacinulate, loosely adnate, $5.5 \mathrm{~cm}$ broad. Sublaciniae dichotomous or irregularly branched, laterally overlapped to \pm crowded, 1.5-5 mm wide, surface continuous or sometimes with irregular depressions, smooth, opaque, becoming slightly rugose and cracked towards the center; apical zone rounded when without lacinulae; margin sinuous-incised or more commonly lacinulate, undulated. Maculae distinct, effigurate, laminal, rarely originating cracks. Cilia black, simple or furcated, up to $1.5 \mathrm{~mm}$ long, $0.03-0.08 \mathrm{~mm}$ wide, frequent. Lacinulae abundant, usually dichotomous, plane, apex rounded, truncate or acute, $1-6 \times 0.5-2 \mathrm{~mm}$. Soralia white, growing from the margin of the lobes and becoming extensive towards the undersurface, the sorediate lobes becoming crescent-shaped and crisped; soredia farinose to subgranular. Pustules and isidia absent. Medulla white. Undersurface black to dark brown in some lobes, beige under the lacinulae (probably white in fresh material),
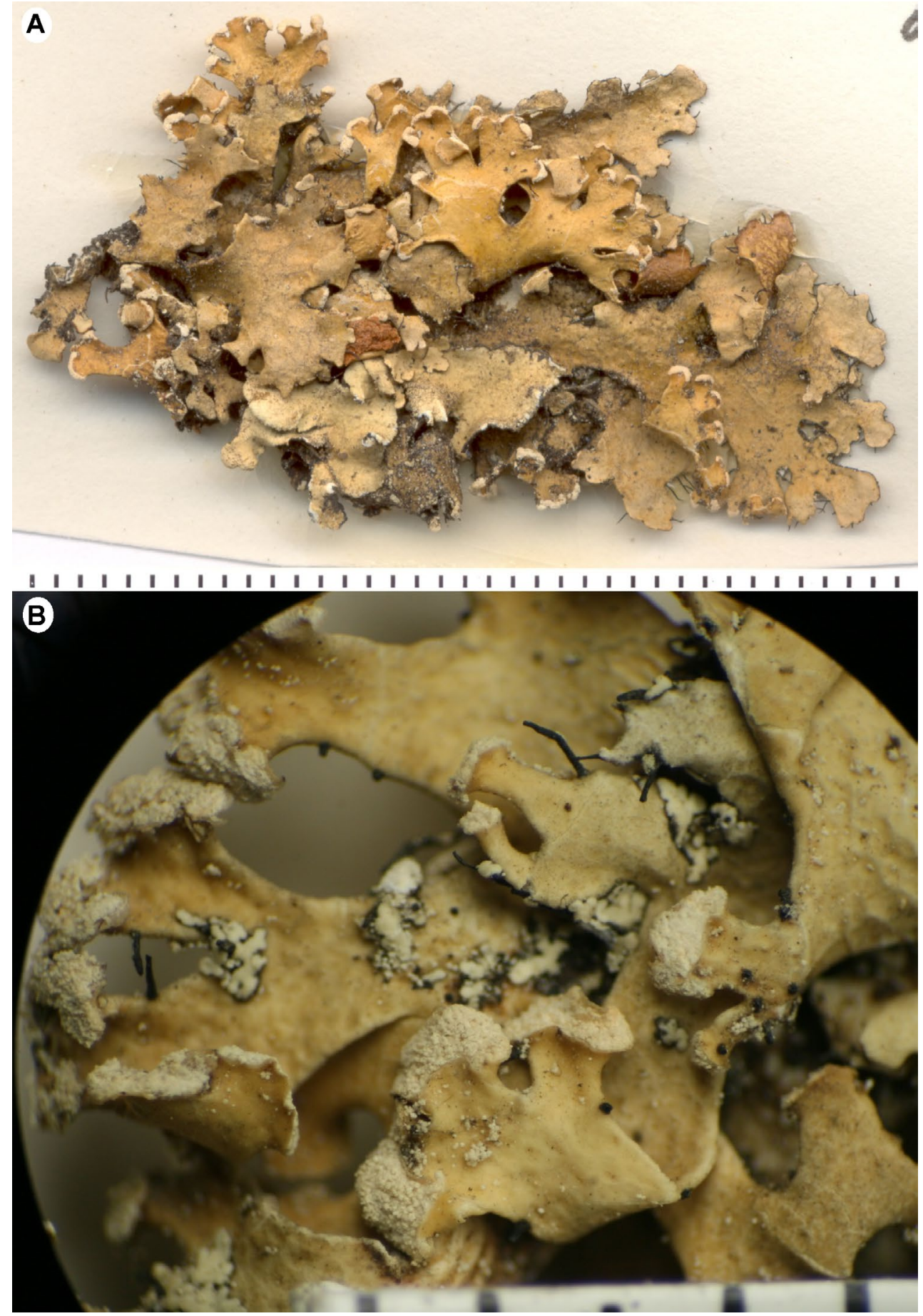

Figure 37. Holotype of Parmotrema parahypotropum (TNS). A - thallus; B - soralia. Scales in milimeters. 
lustrous, smooth or with reticulate veins, with few cracks; marginal zone brown or beige under the lacinulae, lustrous, 1-3 mm wide, naked, with an attenuated limit, usually slightly rugose or veined; rhizines black or rarely with pale brown apices, simple, usually glued to each other, up to $1 \mathrm{~mm}$ long, $0.02-0.1 \mathrm{~mm}$ wide, abundant, irregularly distributed.

Apothecia unknown. Pycnidia submarginal to laminal, conspicuous, with or without prominent margin, few, ostiole black; conidia unciform, $4-5 \times \sim 1 \mu \mathrm{m}$.

Chemistry. Atranorin (minor), chloroatranorin (minor), salazinic acid (minor), norstictic acid (major), galbinic acid (major), consalazinic acid (trace). Cortex $\mathrm{K}+$ yellow, $\mathrm{UV}-$; medulla $\mathrm{K}+$ yellow $\rightarrow$ slowly red-orange, $\mathrm{C}-$, $\mathrm{KC}-$, $\mathrm{P}+$ strong yellow, UV-.

Remarks. Parmotrema parahypotropum is characterized by the lacinulate thallus with marginal soralia that grow towards the undersurface, the effigurate maculae, unciform conidia and complex medullar chemistry, with salazinic, norstictic and galbinic acids. Soralia ontogeny is very similar to that found in P. subsumptum, the sorediate lacinulae usually becoming crescent-shaped or crisped. However, the abundant lacinulae, chemistry, conidia type, furcated cilia and absence of dimorphous rhizines can be used to set these species apart.

$P$. parahypotropum is the only known species with salazinic acid and unciform conidia, this last feature here being reported for the first time.

Distribution. Africa (Krog \& Swinscow 1981, Kurokawa 2003, Aptroot 2008), Asia (Culberson 1973) and Australia (Elix 1994).

Parmotrema paramoreliense W.L. Culb. \& C.F. Culb., The Bryologist 84(3): 311. 1981.

(Figs 2C, 38A)

Type: Mexico. Michoacán: $33 \mathrm{Km}$ E of Uruapan on the road to Patzcuaro, pine-oak woods, on a fallen branch of Pinus sp., 28.XII.1978, W.L. Culberson \& C.F. Culberson 18171 (holotype - DUKE!).

Description (based on holotype). Thallus pale buff (herbarium), laciniate, loosely adnate, corticicolous, $8 \mathrm{~cm}$ broad. Laciniae dichotomous or irregularly branched, laterally overlapped to somewhat crowded, 1-5.5 mm wide, surface continuous, smooth, opaque to sublustrous, becoming cracked in the center; apical zone acute or sometimes truncate; margin sinuous, plane, with a strong black line (Fig. 52). Maculae distinct, effigurate or sometimes forming strong rounded spots, laminal, originating cracks or not. Cilia black, simple or sometimes furcated, up to $5 \mathrm{~mm}$ long, usually thickened, $0.05-0.2 \mathrm{~mm}$ wide, frequent. Soralia capitate, orbicular or forming irregular agglomerations, subapical or laminal; soredia subgranular. Lacinulae, pustules and isidia absent. Medulla white. Undersurface black, lustrous, smooth to rugose, with cracks, widely naked; marginal zone absent or brown, lustrous, 1-5 mm wide, naked, with a sharp or attenuated limit, smooth to slightly rugose; rhizines black, irregular in size and ramification, simple to variously branched, up to $5 \mathrm{~mm}$ long, thin or thickened, $0.01-0.3 \mathrm{~mm}$ wide, sparse.

Apothecia unknown. Pycnidia submarginal or laminal, rare, ostiole black; conidia not found (five pycnidia examined).

Chemistry. Atranorin (minor), chloroatranorin (minor), salazinic acid (major), consalazinic acid (minor). Cortex $\mathrm{K}+$ yellow, $\mathrm{UV}-$; medulla $\mathrm{K}+$ yellow $\rightarrow$ blood red, $\mathrm{C}-$, $\mathrm{KC}-, \mathrm{P}+$ strong yellow, $\mathrm{UV}-$.

Remarks. Parmotrema paramoreliense can be recognized by the laciniate, sorediate thallus, effigurate maculae, black and widely naked undersurface, long cilia (up to $5 \mathrm{~mm}$ ) and variedly branched, sometimes very thick rhizines (up to $0.3 \mathrm{~mm}$ ). This is a strange species inside the group of Parmotrema with salazinic acid, being probably more related to the genus Everniastrum Hale ex Sipman (now Hypotrachyna suben. Everniastrum, see Divakar et al. 2013). Although the effigurate maculae and dimorphic rhizines could place P. paramoreliense together with the species of the former genus Rimeliella, the remaining features are not found in this group. Future investigations in the ascospores and conidia, not known up to now, can help to clarify the positioning of this taxon.

Although Culberson \& Culberson (1981) asserted that pycnidia are relatively common in this species, they are rare in the holotype, and no conidia could be seen.

Distribution. Americas (Culberson \& Culberson 1981, Egan et al. 2016).

Parmotrema pectinatum Jungbluth \& Marcelli, Bibliotheca Lichenologica 96: 220. 2007.

(Fig. 38B)

Type: Brazil. São Paulo: Municipality of Itirapina, SP-225 Road, $\mathrm{Km} \mathrm{111,} \mathrm{on} \mathrm{a} \mathrm{large} \mathrm{red} \mathrm{arenite} \mathrm{rock} \mathrm{emergent} \mathrm{above} \mathrm{the}$ cerrado forest canopy, in direct sunlight, $22^{\circ} 15^{\prime} \mathrm{S}, 47^{\circ} 49^{\prime} \mathrm{W}$, 770 m alt., 16.VI.1979, M.P. Marcelli, K. Kalb \& A.E. Luchi 16077 (holotype - SP!).

Chemistry. Usnic acid, salazinic acid, consalazinic acid and gyrophoric acid (Marcelli et al. 2007).

Remarks. This species was recently described for São Paulo (Marcelli et al. 2007) and is characterized by a laciniate thallus with narrow laciniate $(0.8-3 \mathrm{~mm})$, and abundantly ciliate lobes. It is close to P. nylanderi, especially regarding the chemistry and the soredia produced from pustules. See comments under this species for more details.

Additional specimens examined. Same data as from the holotype, M.P. Marcelli, K. Kalb \& A.E. Luchi 16075, 16079 (SP).

Parmotrema permaculatum (Hale) Kurok., Bulletin of the National Science Museum Tokyo, Ser. B, 27(1): 8. 2001.

(Fig. 39)

Basionym: Parmelia permaculata Hale, Phytologia 21(6): 425. 1971.

Type: Mexico. Veracruz: $9 \mathrm{Km}$ East of Jalapa along highway 140, $1240 \mathrm{~m}$ alt., open pasture, scattered cactus and Acacia, 


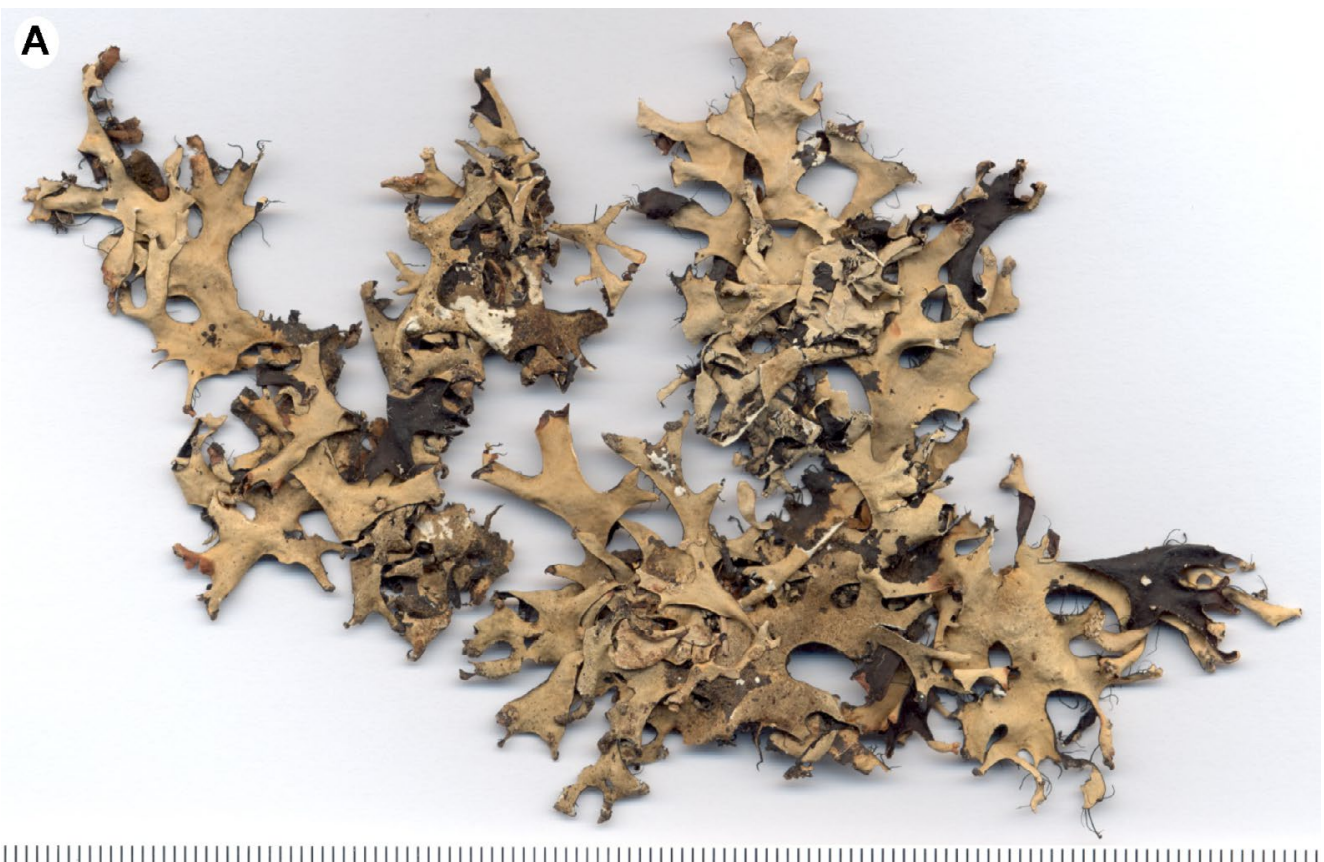

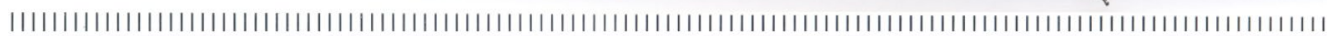

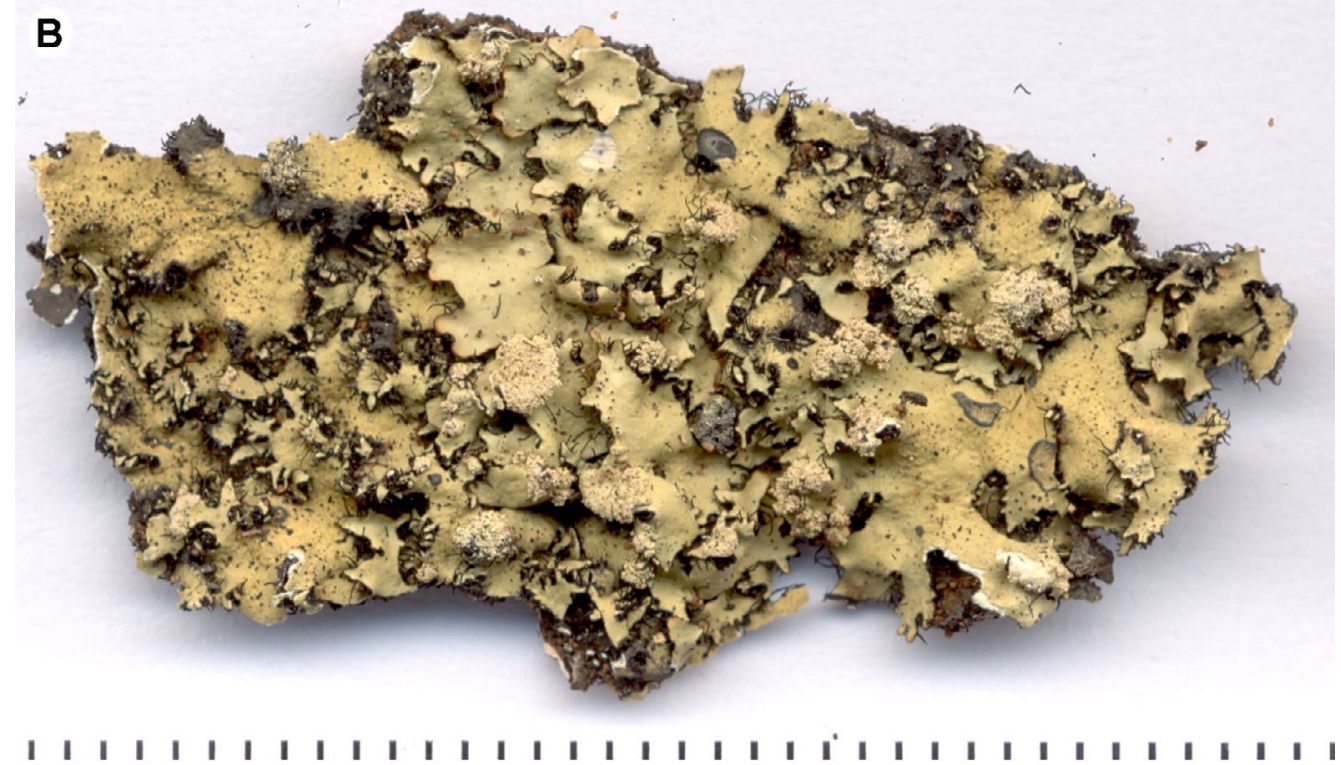

Figure 38. A - holotype of Parmotrema paramoreliense (DUKE); B - bolotype of Parmotrema pectinatum (SP). Scales in milimeters.

on deciduous trees, 13.III.1960, M.E. Hale \& T.R. Soderstrom 19406 (holotype - US!; isotypes - DUKE!, S, TNS, UPS).

Description (based on holotype). Thallus milky brown, lobate, loosely adnate, corticicolous, $15 \mathrm{~cm}$ broad. Lobes irregularly branched, laterally overlapped, 4-17 mm wide, surface continuous, smooth or with tiny depressions, lustrous, becoming rugose and reticulately cracked towards the center, sometimes with flaking off areolae; apical zone rounded; margin sinuous to broadly crenate, sometimes with deep incisions, undulated. Maculae distinct, effigurate to sometimes pseudoreticulate, laminal, originating cracks. Cilia black, sometimes pruinose, simple, up to $2 \mathrm{~mm}$ long, 0.04-0.1 mm wide, abundant. Lacinulae, pustules, soredia and isidia absent. Medulla white. Undersurface black, opaque to lustrous (satin-like), smooth, rugulose or papillate, with cracks; marginal zone brown, sometimes white mottled, lustrous, 3-7 mm wide, naked, with attenuated limit, smooth to rugulose or minutely veined; rhizines concolor to the undersurface or sometimes with whitish apices, simple to irregularly branched, up to $1.5 \mathrm{~mm}$ long, $0.01-0.1 \mathrm{~mm}$ wide, abundant, evenly distributed.

Apothecia cupuliform, up to $15 \mathrm{~mm}$ in diameter, stipitate, laminal to submarginal, margin slightly incised to lacerate, usually involute, amphithecium maculate, smooth to scrobiculate or longitudinally rugose and foveolate; ascospores ellipsoid, 13-17 × 7-9 $\mu \mathrm{m}$, episporium 0.5-1 $\mu \mathrm{m}$. Pycnidia submarginal, conspicuous, without prominent margin, frequent, ostiole black; conidia filiform, $10-15 \times \sim 1 \mu \mathrm{m}$.

Chemistry. Atranorin (minor), chloroatranorin (trace), salazinic acid (major), consalazinic acid (minor), norstictic acid (trace). Cortex $\mathrm{K}+$ yellow, UV-; medulla $\mathrm{K}+$ yellow $\rightarrow$ blood red, $\mathrm{C}-$, $\mathrm{KC}-$, $\mathrm{P}+$ strong yellow, $\mathrm{UV}-$. 


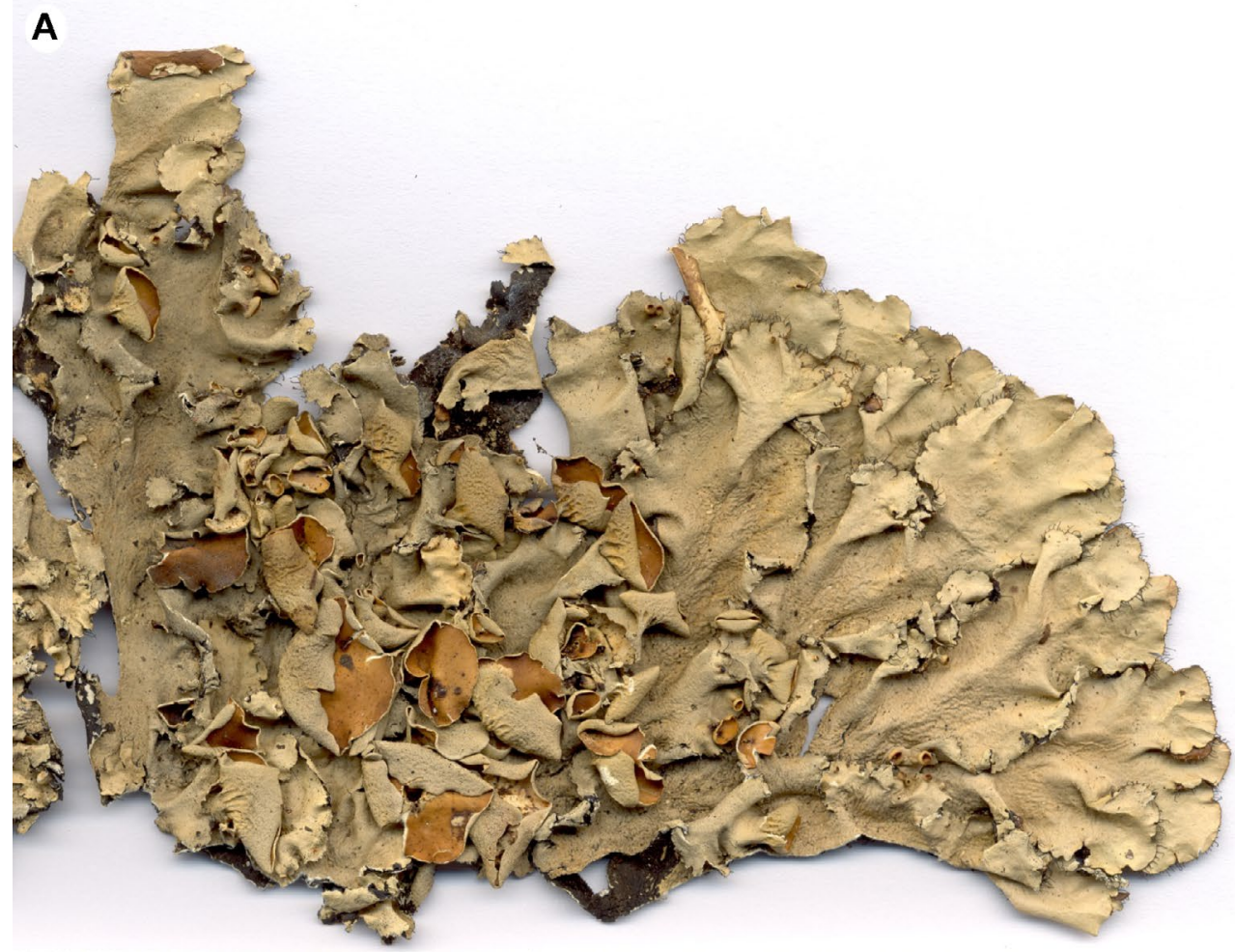

||||||||||||||||||||||||||||||||||||||||||||||||||||||||||||||||||||||||||||||||||||||||||||||||||||||||||||||||||||||||+|||||||||||||

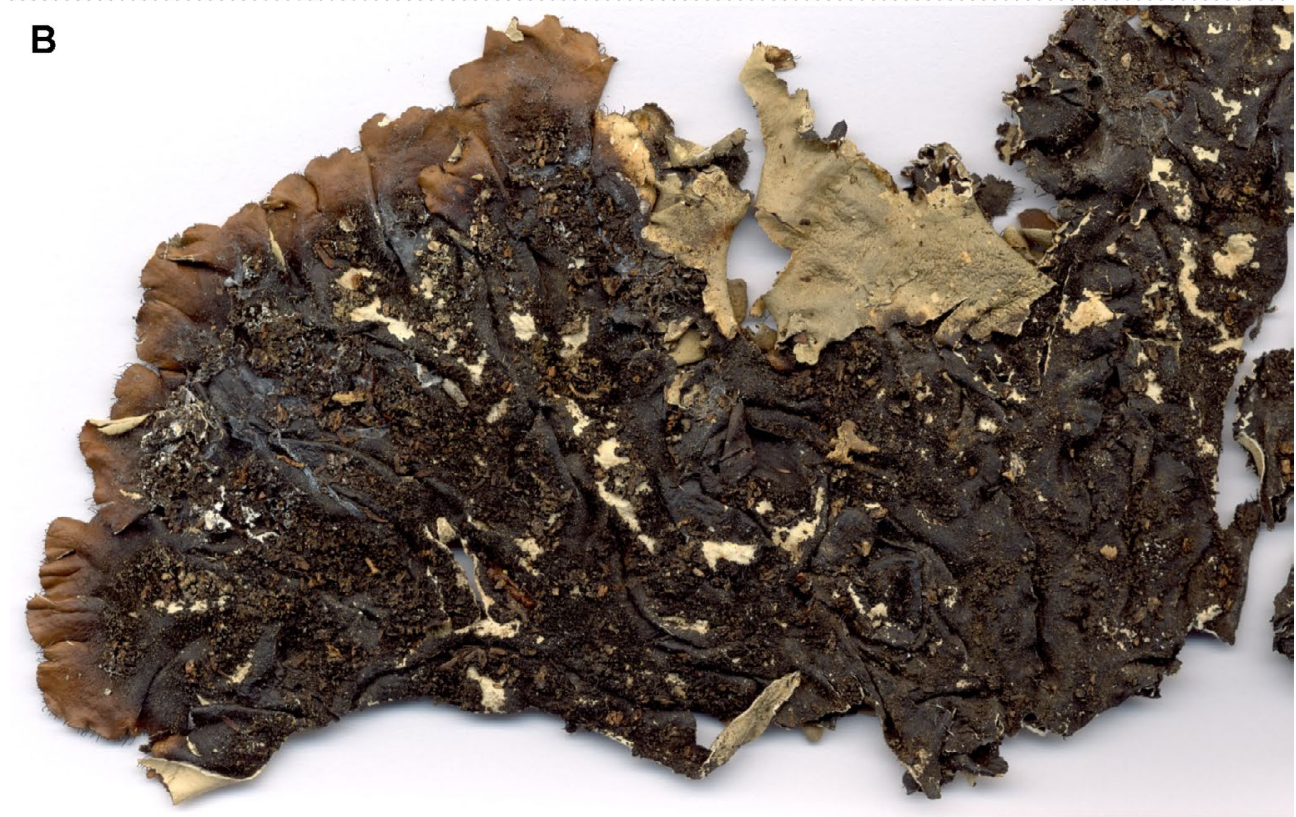

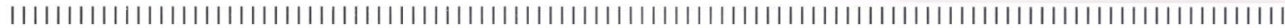

Figure 39. Holotype of Parmotrema permaculatum (US). A - upper surface; B - undersurface. Scales in milimeters.

Remarks. Parmotrema permaculatum is distinguished by the effigurate maculae (sometimes pseudoreticulate), simple or less frequently branched cilia, black undersurface and absence of vegetative propagules. It is morphologically similar to $P$. expansum, which also develops effigurate maculae, but has furcated cilia and shorter conidia (7-12 $\mu \mathrm{m})$. To compare it with other species usually confused in the literature, see comments under P. eurysacum and $P$. despectum.

The isotype of $P$. permaculatum in DUKE was not listed in the protologue (Hale 1971). It is similar in every respect with the holotype, but develops more abundant pycnidia and the venation in the undersurface is more evident. Branched cilia occur in the specimen Hale \& Soderstrom 19378 (US). This and the specimen Hale \& Soderstrom 19394 agree well with holotype. However, the specimen Hale \& Soderstrom 19529 (US) presents the margin of the lobes usually blackened, and the maculation is not as strong as in the other specimens, making the upper surface more lustrous, and the undersurface of the lobe apices is usually dark brown. Finally, in the specimen Purpus 210 (US), the maculae are also not so developed, but it presents the undersurface of the lobe apices usually pale brown. 
Distribution. United States and Mexico (Hale 1971, Kurokawa 2001, Egan et al. 2016).

Additional specimens examined. MEXICO. Veracruz: $9 \mathrm{Km}$ East of Jalapa along highway 140, $1240 \mathrm{~m}$ alt., open pasture, scattered cactus and Acacia, on deciduous trees, 13.III.1960, M.E. Hale \& T.R. Soderstrom 19394, 19378 (US). Idem, 64 Km southwest of junction of highway 140 and 155, northeast of Huatusco, $1310 \mathrm{~m}$ alt., scattered shade trees in coffee plantation, 13.III.1960, M.E. Hale \& T.R. Soderstrom 19529 (US). Idem, Mirador, an Yuccastämmen, 1000 m, 1921-1922, T.A. Purpus 210 (US).
Parmotrema petropoliense (Zahlbr.) Spielmann \& Marcelli, comb. nov.

(Fig. 40)

\section{MycoBank MB 838191}

Basionym: Parmelia petropoliensis Zahlbr., Sitzungsberichte der Kaiserlichen Akademie der Wissenschaften Wien, Mathematisch-Naturwissenschaftliche 111: 426. 1902.

Type: Brazil. Rio de Janeiro: Fazenda Inglês prope [Municipality of] Petrópolis, in forest, corticicolous, Höhnel 177 (holotype - W!).

Description (based on holotype). Thallus pale brown to brown (herbarium), lobate, loosely adnate, corticicolous,
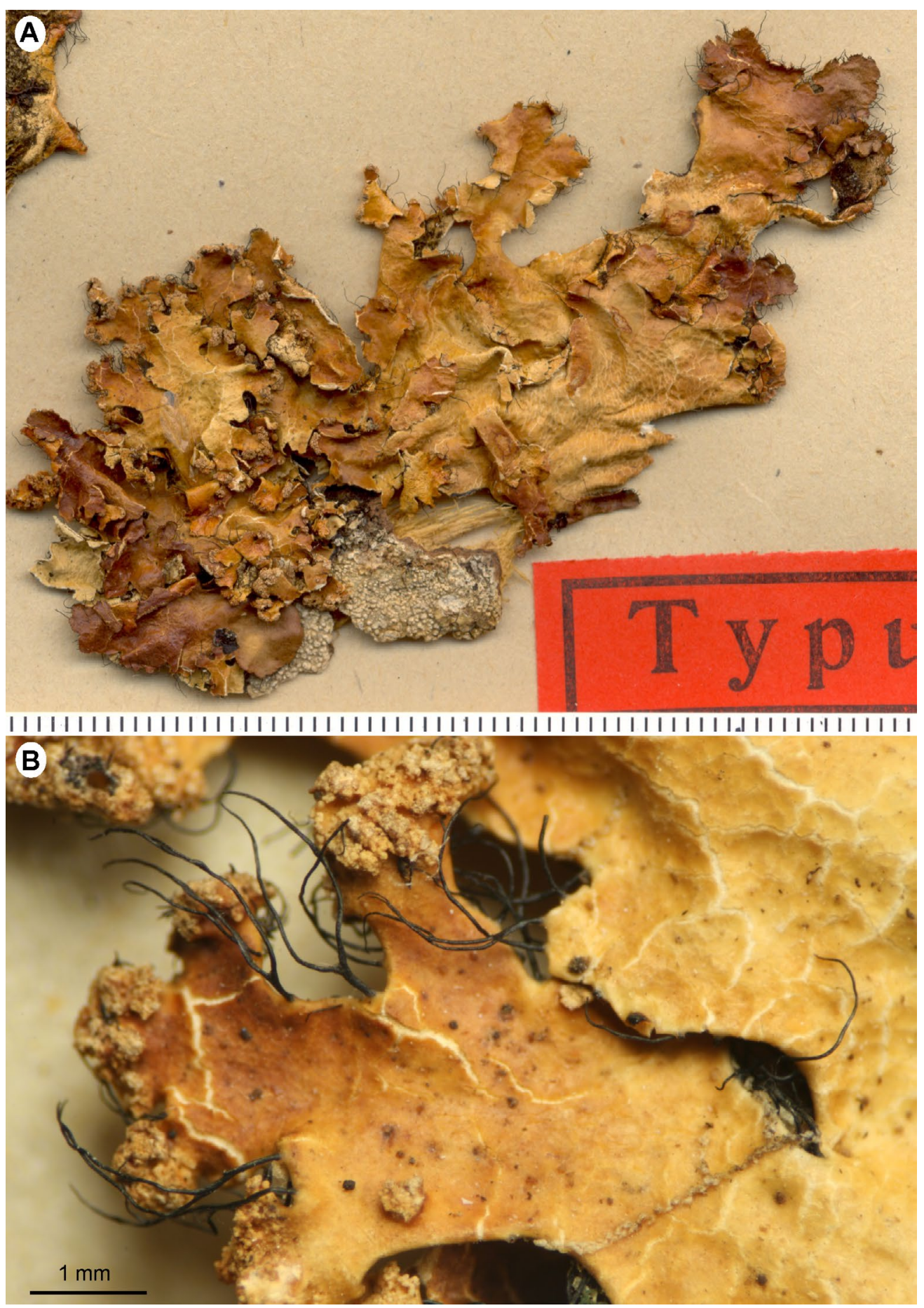

Figure 40. Holotype of Parmotrema petropoliense (W). A - thallus; B - soralia and cilia. Scales in milimeters or as indicated. 
5-7 $\mathrm{cm}$ broad. Lobes irregularly branched, laterally overlapped to quite crowded, 3-6 mm wide, surface continuous or irregularly cracked, smooth or with tiny depressions, lustrous, becoming irregularly rugose and reticulately cracked towards the center; apical zone rounded; margin crenate to incised or lacinulate, undulated. Maculae usually weak, distinct in some lobes, effigurate, laminal, originating cracks or not. Cilia black, simple or frequently furcated, up to $3 \mathrm{~mm}$ long, $0.02-0.1 \mathrm{~mm}$ wide, abundant. Lacinulae usually simple or irregularly branched, plane, apex rounded or \pm truncate, $1-4 \times 0.5-3 \mathrm{~mm}$. Soredia originated from pustuloid raised structures, marginal to subapical, rarely laminal; soredia granular, commonly developing into granules, frequently united in agglomerations and forming cilia. Isidia absent. Medulla white. Undersurface pale brown or dark reddish brown, lustrous, smooth, papillate or slightly rugose in some areas, without cracks; marginal zone absent or usually darker than the center; rhizines black, dimorphic, the shorter ones simple or furcated to dichotomous, usually curled, up to $1 \mathrm{~mm}$ long, thin, 0.01-0.04 mm wide, abundant, evenly distributed; the longer ones up to $1.5 \mathrm{~mm}$ long, thickened, $0.05-0.1 \mathrm{~mm}$ wide, simple or irregularly branched, few, distributed in groups.

Apothecia absent. Pycnidia submarginal, inconspicuous, rare, ostiole black; conidia not found.

Chemistry. Atranorin (minor), chloroatranorin (trace), salazinic acid (major), consalazinic acid (minor). Cortex $\mathrm{K}+$ yellow, UV-; medulla $\mathrm{K}+$ yellow $\rightarrow$ blood red, $\mathrm{C}-$, $\mathrm{KC}-$, $\mathrm{P}+$ strong yellow, $\mathrm{UV}-$.

Remarks. Parmotrema petropoliense is recognized by the marginal to submarginal pustuloid raised structures that give rise to soredia, long (up to $3 \mathrm{~mm}$ ), abundant and frequently furcated cilia, the brown undersurface with dichotomous rhizines and the effigurate maculae. This species has long been recognized as a synonym of $P$. subsumptum, which has extensive soralia growing in the undersurface. For more details and to differentiate also from P. margaritatum, see the comments under P. subsumptum.

The holotype collection consisted of three thalli glued on a paper card. They are well-preserved and developed, although without apothecia, and one thallus is glued by the upper surface.

Distribution. Brazil, Rio de Janeiro (Zahlbruckner 1902).

Parmotrema pontagrossense (Eliasaro \& Adler) Blanco, Crespo, Divakar, Elix \& Lumbsch, Mycologia 97(1): 157. 2005.

(Fig. 41A)

Basionym: Rimelia pontagrossensis Eliasaro \& Adler, Mycotaxon 66: 127. 1998.

Type: Brazil. Paraná: Municipality of Ponta Grossa, Buraco do Padre, corticicolous, $25^{\circ} 07^{\prime} \mathrm{S}, 50^{\circ} 15^{\prime} \mathrm{W}, 27$ January 1996 , S. Eliasaro \& M. Adler 1621 (holotype - UPCB-28650!; isotypes - BAFC-37879!, CANB).

Description (based on holotype). Thallus stramineous (herbarium), lobate, more or less closely adnate, corticicolous, $11 \times 7 \mathrm{~cm}$ broad. Lobes irregularly branched, laterally overlapped to somewhat overlapping, $5-13 \mathrm{~mm}$ wide, surface continuous or cracked, smooth to rugose and scrobiculate, lustrous, becoming almost completely reticulately cracked in the center; apical zone usually rounded; margin crenate to sublacinulate, slightly plane to undulated. Maculae distinct to strong, punctiform to effigurate, laminal, sometimes covering almost all the surface, usually connecting in pseudoreticulate formations. Cilia black, simple or more frequently $2-3$-furcated or cespitose, $0.2-1.5 \times 0.02-0.05 \mathrm{~mm}$, abundant. Isidia, lacinulae and pustules absent. Soralia marginal, usually interrupted, sometimes extensive, rarely orbicular; soredia granular. Medulla white. Undersurface black, lustrous, rugose or papillate, with some cracks; marginal zone dark brown, $1-3 \mathrm{~mm}$ wide, naked, rarely papillate or with small rhizines, with an attenuated limit; rhizines black, simple, $0.5-2(-4) \times 0.01-0.1 \mathrm{~mm}$, abundant, apparently evenly distributed, but very dense near the marginal zone.

Apothecia unknown. Pycnidia submarginal, little conspicuous, without prominent margin, few, ostiole black; conidia not found ( $\sim 20$ pycnidia investigated; the isotype from BAFC! has filiform conidia, 9-11 $\times \sim 1 \mu \mathrm{m}$ ).

Chemistry. Atranorin (minor), chloroatranorin (trace), salazinic acid (major), consalazinic acid (minor), lichexanthone (minor), lichesterinic acid (major), protolichesterinic acid (major). Cortex $\mathrm{K}+$ yellow, UV-; medulla $\mathrm{K}+$ yellow $\rightarrow$ blood red, $\mathrm{C}-, \mathrm{KC}-, \mathrm{P}+$ strong yellow, $\mathrm{UV}+$ yellow.

Remarks. Parmotrema pontagrossense is distinguished by the sorediate thallus with cespitose cilia and by the complex chemistry, with salazinic acid, lichexanthone (see comments under P. ultralucens) and the lichesterinic and protolichesterinic acids in the medulla. The branching pattern of the cilia was already well described in the protologue (Eliasaro \& Adler 1998). The same pattern can be seen in Parmotrema spinibarbe, a close species with the same overall morphology, but that can be differentiated by the formation of soredia from botryose structures, as well as by the absence of lichesterinic and protolichesterinic acids. Future collections of fertile material will perhaps provide additional differences between these two species.

The types studied are well-developed and completely similar. The undersurface is difficult to access since the thalli are closely adnate to the substrate; however, the free zone close to the margins presented sufficient diagnostic features.

Distribution. Known only from Brazil, where it was recorded from Paraná (Eliasaro \& Adler 1998; Donha 2005) and Rio Grande do Sul (Canêz 2005).

Parmotrema pseudoreticulatum (Tavares) Hale, Phytologia 28(4): 338. 1974.

(Fig. 41B)

Basionym: Parmelia pseudoreticulata Tavares, Portugaliae Acta Biologica, série B, 1(1-2): 138. 1945.

Type: Portugal. Surroundings of Lisboa, C. Tavares (holotype - LSU, isotype - F!). 

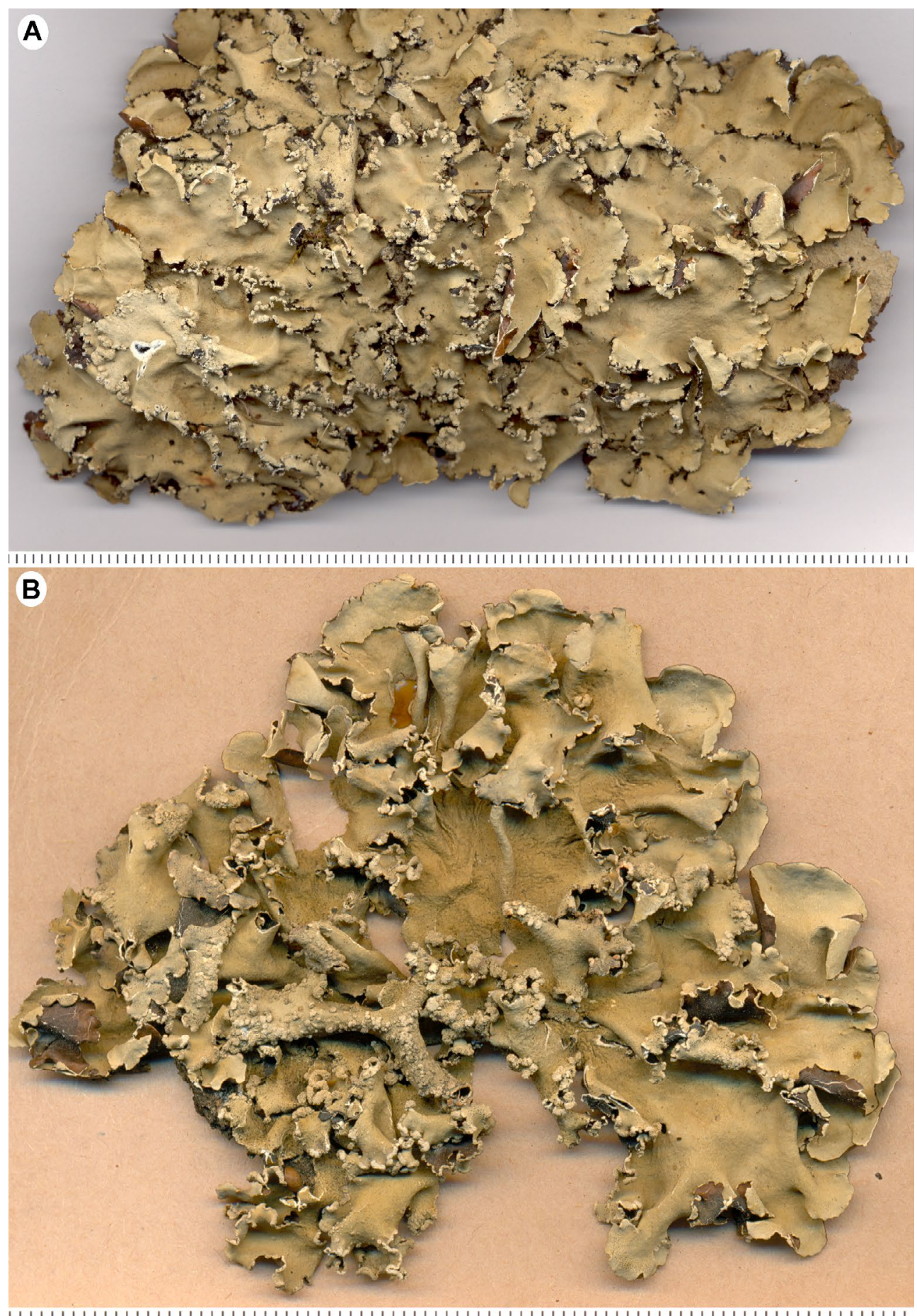

Figure 41. A - holotype of Parmotrema pontagrossense (UPCB); B - isotype of Parmotrema pseudoreticulatum (F). Scales in milimeters.

= Parmelia perlata var. olivaria Ach., Meth. Lich.: 217. 1803. Nom. rej. (Hawksworth et al. 2003).

Type: Spain. Sine loc., on Olea, 1971-93, P.K. A. Schousboë (lectotype, selected by Hawksworth et al. $2003-\mathrm{H}-\mathrm{ACH}$ 1327c), according to Divakar et al. (2005).

$\equiv$ Parmelia olivaria (Ach.) Hue, Nouv. Arch. Mus. Hist. Nat. Paris, sér. 4(1): 195. 1899. According to Divakar et al. (2005).

$\equiv$ Rimelia olivaria (Ach.) Hale \& Fletcher, The Bryologist 93(1): 28. 1990. According to Divakar et al. (2005).

Description (based on isotype from F). Thallus buff (herbarium), lobate, apparently loosely adnate, corticicolous,
8.5-7 cm broad. Lobes irregularly branched, laterally overlapped to somewhat crowded, 4-12 mm wide, surface continuous, smooth or irregular, lustrous, becoming rugose and cracked in the center; apical zone rounded, usually concave; margin smooth to crenate or broadly crenate, sometimes deeply incised, undulated. Maculae distinct, punctiform or effigurate, sometimes assuming a reticulate pattern, laminal, in some areas covering almost all the surface (hypermaculate). Cilia black, simple, up to $0.5 \mathrm{~mm}$ long, rare. Soralia marginal and linear or more commonly laminal and capitate, sometimes extensive; soredia subgranular. Lacinulae, pustules and isidia absent. 
Medulla white. Undersurface black, lustrous, usually finely rugose, with few cracks; marginal zone pale brown, lustrous, 1-5 mm wide, naked or rarely rhizinate, with an attenuated limit, smooth, rugose or papillate; rhizines black, simple, up to $1 \mathrm{~mm}$ long, abundant, evenly distributed.

Apothecia absent. Pycnidia submarginal, conspicuous, without prominent margin, abundant, ostiole black; conidia filiform, 8-14 $\times \sim 1 \mu \mathrm{m}$.

Chemistry. Atranorin (minor), chloroatranorin (trace), salazinic acid (major), consalazinic acid (minor), protocetraric acid (trace). Cortex $\mathrm{K}+$ yellow, $\mathrm{UV}-$; medulla $\mathrm{K}+$ yellow $\rightarrow$ blood red, $\mathrm{C}-$, $\mathrm{KC}-$, $\mathrm{P}+$ strong yellow, $\mathrm{UV}-$.

Remarks. Parmotrema pseudoreticulatum is distinguished by the abundant laminal and capitate soralia, the rare short cilia (up to $0.5 \mathrm{~mm}$ ), the punctiform to effigurate maculae and naked under the marginal zone. At first sight, this seems to be a typical Rimelia; however, it is easy to verify that the (false) reticulation is formed by the confluence of the maculae, i.e., the maculae are actually punctiform or effigurate as those of former Canomaculina. Parmotrema pseudoreticulatum was considered to be a synonym of $P$. reticulatum by Krog \& Swinscow (1981), which has distinct reticulate maculae, under the marginal zone rhizinate, soralia growing in short lacinulae and more numerous cilia. The distinction between them was also molecularly supported (Hawksworth et al. 2003; Divakar et al. 2005).

The isotype here described was not listed in the pertinent literature. It is well-preserved and developed, although sterile, and glued on a paper card.

Distribution. Europe and Azores (Tavares 1945; Hawksworth et al. 2003) and Africa (Divakar et al. 2005).

Parmotrema radiatum (Lynge) Spielmann \& Marcelli, comb. et stat. nov.

(Fig. 42A)

MycoBank MB 838193

Basionym: Parmelia cetrata subsp. radiata Lynge, Arkiv för Botanik 13(13): 94. 1914.

Type: Paraguay. Colonia Risso prope Río Apa, corticicolous, 23.IX.1893, G.O.A. Malme 1834 (lectotype - S!; isolectotype - UPS!).

Description (based on lectotype). Thallus brownish (herbarium), lobate, loosely adnate, corticicolous, $10.5 \mathrm{~cm}$ broad. Lobes irregularly branched, laterally overlapped, distinctly radial, 3-7.5 mm wide, surface continuous, smooth, lustrous, frequently pruinose in the lobe apices, becoming slightly rugose and reticulately cracked towards the center; apical zone rounded; margin crenate to sinous-incised, undulated. Maculae distinct, reticulate to extensive (hypermaculate), laminal, marginal, originating cracks. Cilia black, usually squarrose, less frequently simple or furcated, up to $1.5(-2) \mathrm{mm}$ long, 0.03-0.1 mm wide, abundant. Lacinulae, pustules, soredia and isidia absent. Medulla white. Undersurface black, lustrous (satin-like), smooth, sometimes papillate or veined, with abundant cracks; marginal zone dark brown, shiny, narrow, 1-2 mm wide, naked or with sparse rhizines, with attenuated limit, smooth or papillate; rhizines black, usually strongly squarrose, sometimes irregularly branched or simple, up to $3 \mathrm{~mm}$ long, thin to thickened, $0.01-0.15 \mathrm{~mm}$ wide, abundant, irregularly distributed.

Apothecia cupuliform, $1-8 \mathrm{~mm}$ in diameter, stipitate, submarginal, margin smooth to dentate, amphithecium maculate, smooth to rugose, disc brown, epruinose, perforate at maturity; ascospores ellipsoid, 11-13 $\times$ 7.5-9 $\mu \mathrm{m}$, episporium 1-1.5 $\mu \mathrm{m}$. Pycnidia submarginal, rarely laminal, conspicuous, usually with a prominent margin, frequent, ostiole black; conidia filiform, 10-15 $\times \sim 1 \mu \mathrm{m}$.

Chemistry. Atranorin (minor), chloroatranorin (trace), salazinic acid (major), consalazinic acid (minor), protocetraric acid (trace). Cortex $\mathrm{K}+$ yellow, UV-; medulla $\mathrm{K}+$ yellow $\rightarrow$ blood red, $\mathrm{C}-$, $\mathrm{KC}-$, $\mathrm{P}+$ strong yellow, $\mathrm{UV}-$.

Remarks. The most salient features of Parmotrema radiatum are the usually squarrose cilia, the upper surface reticulate-maculate or hypermaculate, the squarrose and richly branched rhizines and the shiny nude dark brown under margin. This species was included by Hale $\&$ Fletcher in the synonymy of $P$. cetratum. Nevertheless, $P$. cetratum presents only reticulate maculae, cilia never squarrose and the marginal zone is totally absent (lectotype - H-ACH).

Lynge (1914) described Parmelia cetrata subsp. radiata based in one specimen from Brazil and another from Paraguay. The Brazilian specimen belongs to a new species, here described (see P. bifidum).

The isolectotype agrees very well with the lectotype, including ascospores and conidial data. It is clearly a part of the holotype thallus. However, the chemical analysis did not demonstrate the presence of traces of protocetraric acid.

Distribution. Paraguay (Lynge 1914).

Parmotrema ramusculum (Hale) Hale, Phytologia 28(4): 338. 1974.

(Figs 5B, 43)

Basionym: Parmelia ramuscula Hale, Contributions from the United States National Herbarium 36(5): 261. 1965.

Type: Malaysia. Borneo Island: Sarawak state, Lawas, on a Rubber tree. 31.V.1955, W.M.A Brooke 10031 (holotype $\mathrm{BM}$ !; isotypes - L!, US).

Description (based on holotype). Thallus grayish, lobate, loosely adnate, corticicolous, $9.5 \mathrm{~cm}$ broad. Lobes irregularly branched, 4-10 mm wide, surface continuous, smooth, sublustrous, becoming irregularly cracked towards the center; apical zone rounded; margin smooth. Maculae weak, punctiform, laminal, more easily seen in young lobes. Cilia black, simple, up to $1.3 \mathrm{~mm}$ long, 0.04-0.1 mm wide, sparse. Lacinulae present, forming arbuscular, sorediate and pustular structures, irregularly branched, usually terete or sometimes flattened, up to $1.5 \mathrm{~cm}$ long, individual branches $0.2-1 \mathrm{~mm}$ wide. Soredia whitish, farinose or becoming more compact, developed in the arbuscular structures and in some lobe margins. True isidia absent. Medulla white. Undersurface (based on 

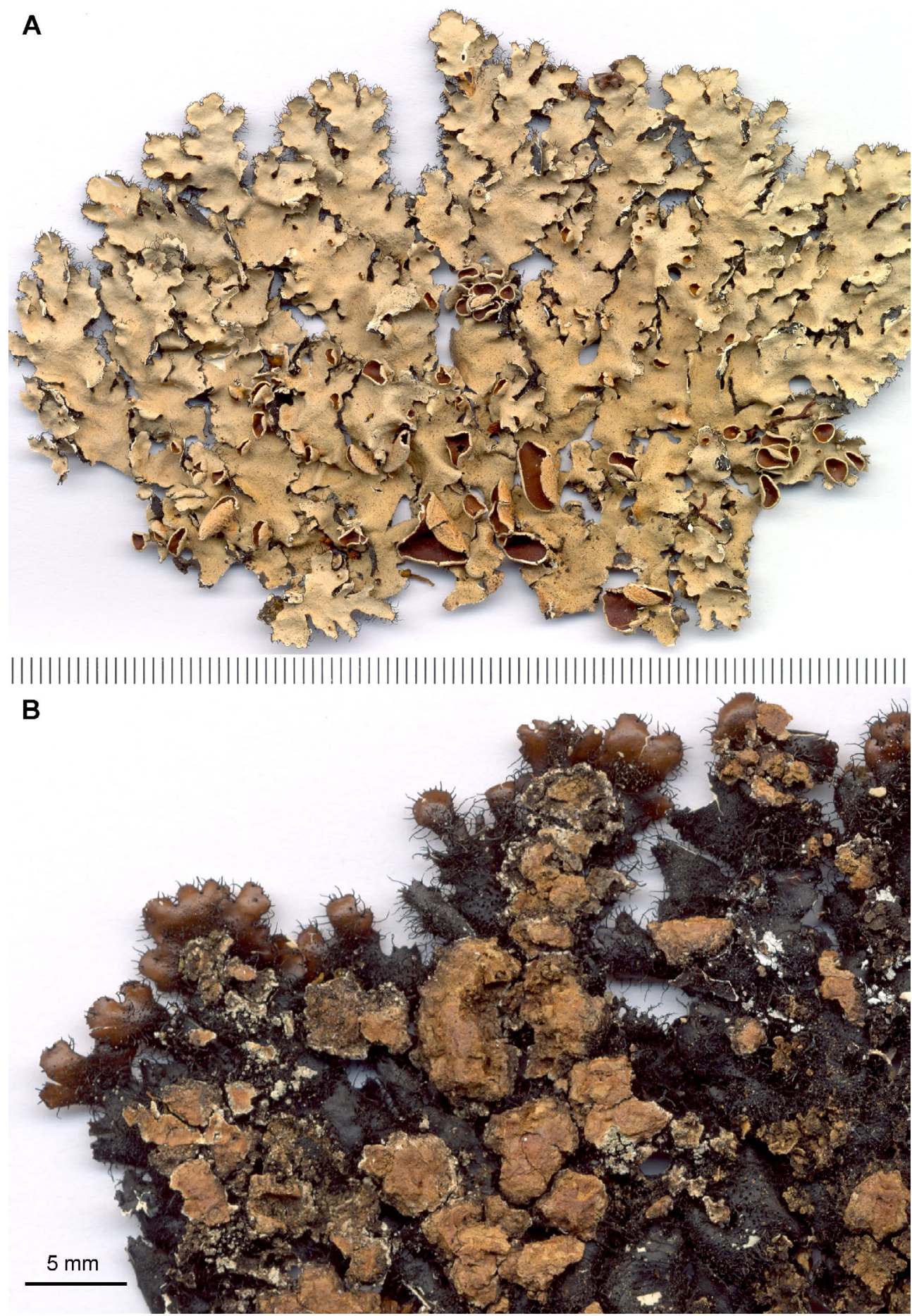

Figure 42. Lectotype of Parmotrema radiatum (S). A - upper surface; B - undersurface showing the brown nude margin. Scales in milimeters or as indicated.

the L isotype): black, lustrous, smooth to slightly rugose or rarely papillate, with numerous cracks; marginal zone absent (black) or eburneus under the lobes that give rise to the arbuscular structures, which are also usually eburneus; rhizines black, simple, up to $1 \times 0.05 \mathrm{~mm}$, rare, distributed in groups.

Apothecia and pycnidia unknown.

Chemistry. Atranorin (minor), chloroatranorin (trace), salazinic acid (major), consalazinic acid (minor). Cortex $\mathrm{K}+$ yellow, UV-; medulla $\mathrm{K}+$ yellow $\rightarrow$ blood red, $\mathrm{C}-$, $\mathrm{KC}-, \mathrm{P}+$ strong yellow, $\mathrm{UV}-$.
Remarks. Parmotrema ramusculum is recognized by the very distinct arbuscular structures that become entirely sorediate. Although these structures were already named as 'coralloid isidia' (Hale 1965), they probably deserve their own name, 'arbusculae', since they are different from anything that could be called 'isidia' in other species. Similar structures are found in P. coralliforme, although in this case they are usually ciliate and not so sorediate as in $P$. ramusculum. Additionally, $P$. coralliforme has distinct effigurate maculae, abundant cilia and rhizines and a pale brown marginal zone in the undersurface. The two other comparable species are $P$. flavotinctum (with 

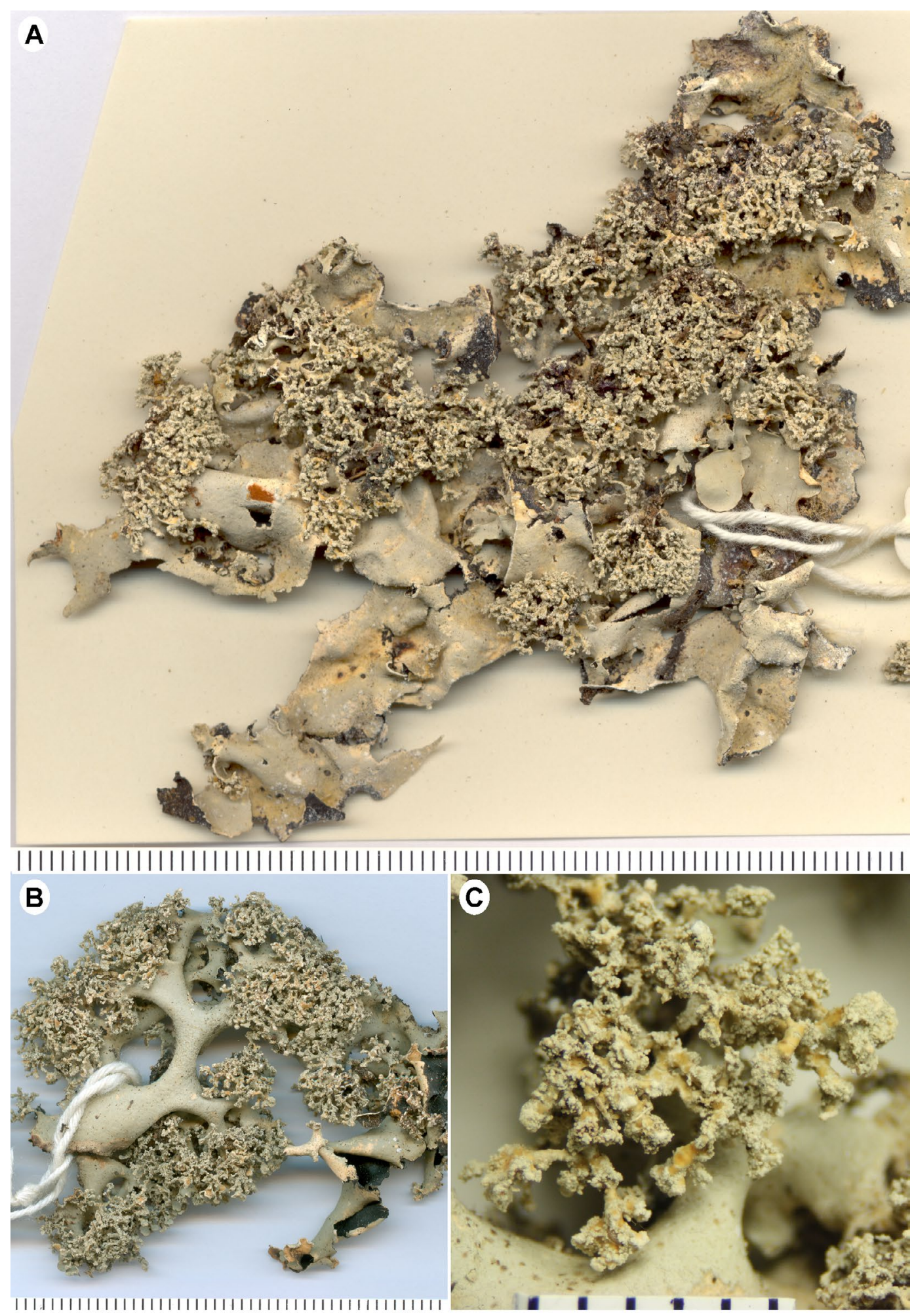

Figure 43. Parmotrema ramusculum. A - holotype (BM); B - isotype (L); C - isotype (L), showing an arbuscula. Scales in milimeters.

atranorin only) and P. fasciculatum (with a very complex chemistry, without salazinic acid, see Louwhoff \& Elix 1999). They also need to be reevaluated before these intriguing structures can adequately named.

The isotype (L) is a well-developed specimen. It has subcanaliculate lobes and more commonly furcated cilia, but in the other features, it is identical to the holotype. Since it is not glued as the holotype, it was used to describe the undersurface.
Distribution. In South America it is known from Mexico (here reported), Guyana (Sipman 1999), Brazil and Argentina (here reported). In Malaysia, it was recorded from Malaysian Borneo and Philippines (Hale 1965).

Additional specimens examined. MEXICO. Oaxaca: $77 \mathrm{Km}$ Northwest of Tehuantepec at Km 719 of on highway 190, 640 m, deciduous trees in rocky desert, 31 March 1960, M.E. Hale \& T.R. Soderstrom 20615 (US). BRAZIL. Amazonas: Manaus, margem direita Rio Solimões, 04.IX.1969, L. Xavier 602 (US). 
Amazonas: Rio Uatumã, $02^{\circ} 15^{\prime} \mathrm{S}, 59^{\circ} 04^{\prime} \mathrm{W}$, Along small stream at end of Lago de Tucumanduba, E of Igarapé Tucumanduba, transition between terra firme and campina, old yard along Rio Uatumã, downstream from campina, upper branches of avocado tree, 13.VIII.1979, W.R. Buck 2841 (US). ARGENTINA. Corrientes: San Cosme, Puerto Gonzales, en selva marginal, 21.V.1979, L. Ferraro et al. 1885 (US).

Parmotrema reitzii Hale, Mycotaxon 5(2): 439. 1977

(Fig. 44)

Type: Brazil. Santa Catarina: Lajes, Locality of Encruzilhada, 950 m alt., on bark, 24.IV.1962, R. Reitz \& R.M. Klein 12927 (holotype - US!).
ECanomaculina reitzii (Hale) Elix, Mycotaxon 65: 477. 1997.

$\equiv$ Rimeliella reitzii (Hale) Fletcher, in DePriest \& B. Hale, Mycotaxon 67: 205. 1998.

Description (based on holotype). Thallus pale brown (herbarium), lobate, loosely adnate, corticicolous, $12-14 \mathrm{~cm}$ broad. Lobes irregularly branched, laterally overlapped, $0.4-17 \mathrm{~mm}$ wide, surface continuous, smooth or with \pm rounded depressions, lustrous, becoming reticulately cracked and sometimes rugose towards the center; apical zone rounded; margin crenate-incised to sublacinulate, undulated. Maculae distinct, effigurate,

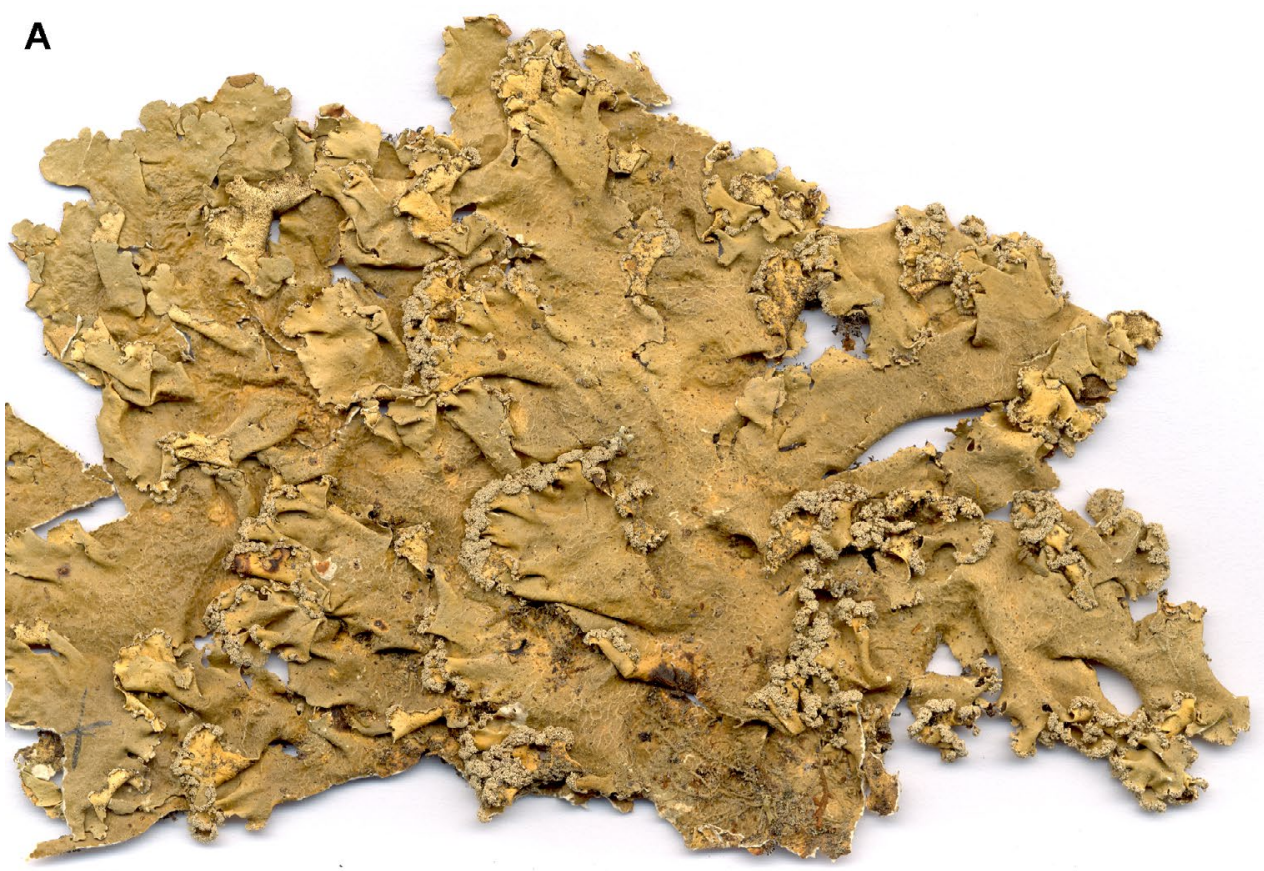

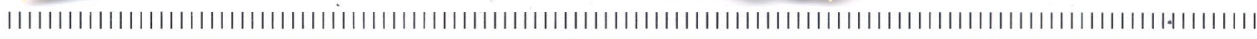

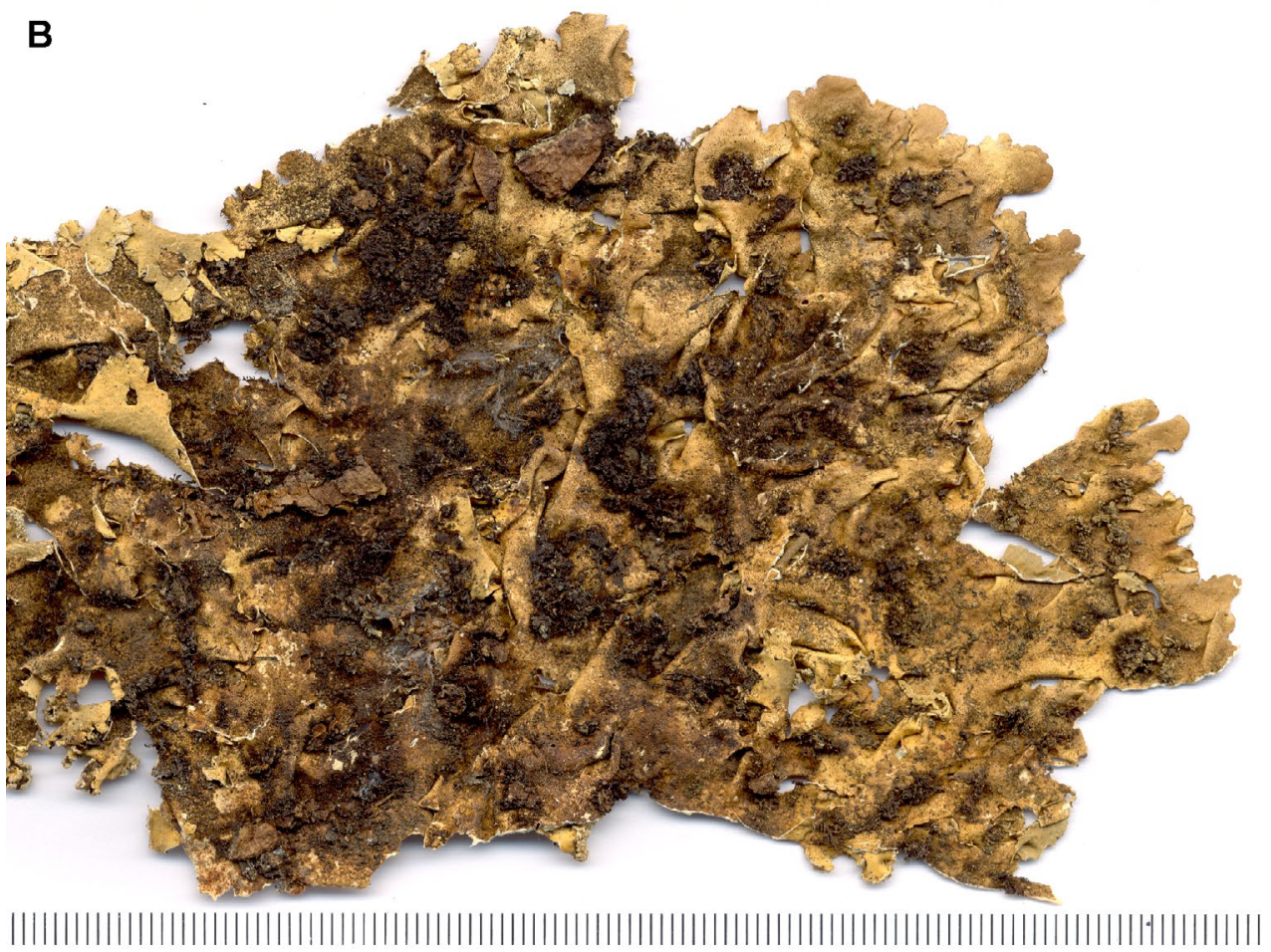

Figure 44. Holotype of Parmotrema reitzii (US). A - upper surface; B - undersurface. Scales in milimeters. 
laminal, originating cracks. Cilia black, simple or rarely with a lateral branchlet, up to $1(-1.5) \mathrm{mm}$ long, thin to somewhat thickened, $0.01-0.1 \mathrm{~mm}$ wide, frequent to few. Soralia whitish, marginal, the soredia usually piling up to form raised arbuscular or richly branched, partially corticated structures, turning the lobe apices involute, assuming a linear pattern when confluent; soredia subfarinose. Lacinulae, pustules and isidia absent. Medulla white. Undersurface pale brown (perhaps white in fresh material), sublustrous, smooth to papillate, without cracks; marginal zone absent; rhizines black or rarely dark brown, dimorphic: 1) the shorter ones simple or sometimes furcated, usually curled, up to $0.5 \mathrm{~mm}$ long, thin, $0.01-$ $0.04 \mathrm{~mm}$ wide, abundant, evenly distributed; 2) the longer ones up to $3.5 \mathrm{~mm}$ long, thickened, $0.05-0.2 \mathrm{~mm}$ wide, simple or more commonly irregularly branched, especially near the apex, frequent, distributed in groups.

Apothecia and pycnidia unknown.

Chemistry. Atranorin (minor), chloroatranorin (trace), salazinic acid (major), consalazinic acid (minor), norlobaridone (minor), loxodin (trace). Cortex $\mathrm{K}+$ yellow, $\mathrm{UV}-$; medulla $\mathrm{K}+$ yellow $\rightarrow$ blood red, $\mathrm{C}-$, $\mathrm{KC}-$, $\mathrm{P}+$ strong yellow, UV-.

Remarks. Parmotrema reitzii is recognized by the submarginal soralia, usually raised and forming branched structures, the pale brown to brown underside, with dimorphic rhizines, and the medullar chemistry, with salazinic acid and norlobaridone. Parmotrema petropoliense produces similar sorediate structures, but with different ontogeny, and has distinct lacinulae and furcated cilia, besides the absence of norlobaridone. Another close species is P. subsumptum (see comments and table under this species), where the soralia grow in the underside of the crisped lobes, and additionally does not produce norlobaridone.

Kurokawa (1991) placed $P$. reitzii as a synonym of Parmotrema conferendum Hale, while Fleig (1997) situated it as a synonym of $P$. subsumptum. The type of $P$. conferendum was not studied here, but based on of the type of $P$. subsumptum and its synonyms, $P$. reitzii is distinct both morphologically (especially the soralia ontogeny) and chemically, i.e., by the production of norlobaridone.

Distribution. South America, where it was recorded from Venezuela (Feuerer 2008) and Brazil (Hale 1977, Marcelli 2008). In Brazil, it is known from Rio Grande do Sul (Fleig 1997) and Santa Catarina (Hale 1977).

Additional specimens examined. VENEZUELA. Táchira: Vía Villa Paez-Betania, valley of Páramo de Tama, open rocky pastures, 2000-2300 m, 25 March 1975, M.E. Hale \& M. López Figueiras 45099 (US). BRAZIL. Santa Catarina: Lajes, Passo do Socorro, 700 m, em pinhal, sobre pau podre, 13 July 1963, Reitz \& Klein 15573 (US).

Parmotrema reparatum (Stirt.) Blanco, Crespo, Divakar, Elix \& Lumbsch, Mycologia 97(1): 157. 2005.

(Fig. 45A)

Basionym: Parmelia reparata Stirt., Scottish Naturalist 4: 201. 1877-78.
Type: Australia. Queensland: Cave Mountain near Brisbane, F.M. Bailey 16 (lectotype - BM!).

$\equiv$ Canomaculina reparata (Stirt.) Kurok., Bulletin of the National Science Museum Tokyo, Ser. B, 27(1): 2. 2001.

= Parmelia virens Müll. Arg., Flora 69: 255. 1886.

Type: Australia. Queensland: Toowoomba, 1882, Hartmann (holotype $-\mathrm{G}$ !).

Description (based on lectotype). Thallus brown (herbarium), lobate, loosely adnate, corticicolous, $7 \mathrm{~cm}$ broad. Lobes irregularly branched, laterally overlapped, 3-9 mm wide, surface continuous, smooth, lustrous, becoming scrobiculate and irregularly cracked towards the center; apical zone rounded; margin broadly crenate, undulated. Maculae distinct, effigurate, laminal. Cilia black, simple or rarely furcated, up to $1.5 \mathrm{~mm}$ long, $0.04-0.07 \mathrm{~mm}$ wide, frequent. Lacinulae, pustules, soredia and isidia absent. Medulla white. Undersurface black, opaque, extensively veined, without cracks; marginal zone absent (i.e., black) or dark brown to brown, then opaque to lustrous, 3-7 mm wide, rhizinate, or papillate; rhizines black or dark brown in the marginal zone, dimorphic, the short ones simple and usually curled, up to $0.5 \mathrm{~mm}$ long, $0.01-0.04 \mathrm{~mm}$ wide, abundant and evenly distributed, the longer ones simple or branched, up to $1.5 \mathrm{~mm}$ long, $0.04-0.1 \mathrm{~mm}$, frequent, distributed in groups.

Apothecia cupuliform, 2-13 $\mathrm{mm}$ in diameter, stipitate, submarginal, margin smooth to slightly incised or lacerate, usually involute, amphithecium maculate, scrobiculate to longitudinally rugose and with deep depressions, disc brown, epruinose, perforate; ascospores subglobose, $10-12.5 \times 8-9 \mu \mathrm{m}$, episporium $\sim 1 \mu \mathrm{m}$. Pycnidia mainly submarginal, conspicuous, with or without prominent margin, frequent; conidia filiform, 9-15 $\times \sim 1 \mu \mathrm{m}$.

Chemistry. Atranorin (minor), chloroatranorin (trace), salazinic acid (major), consalazinic acid (minor). Cortex $\mathrm{K}+$ yellow, $\mathrm{UV}-$; medulla $\mathrm{K}+$ yellow $\rightarrow$ blood red, $\mathrm{C}-$, $\mathrm{KC}-, \mathrm{P}+$ strong yellow, $\mathrm{UV}-$.

Remarks. Parmotrema reparatum is recognized by the effigurate maculae, simple cilia, black undersurface, dimorphic rhizines and the absence of vegetative propagules. Parmotrema subcaperatum is quite similar in overall morphology, but the marginal zone is more distinct, the ascospores larger $(14-16 \mu \mathrm{m})$, and additionally contains usnic acid. Parmelia virens has the same overall morphology of $P$. reparata, except for the darker, olivaceous upper surface. Therefore, we are accepting the synonymization proposed by Kurokawa (2001), although some comments are necessary. When describing Parmelia reparata, Stirton (1877-1878) noted ascospores 13-14 × 9-11 $\mu \mathrm{m}$. The study of the lectotype revealed ascospores briefly shorter and subglobose, $10-12.5 \times 8-9 \mu \mathrm{m}$, while the holotype of $P$. virens presented still smaller measurements, of also subglobose ascospores, 7.5-12 × 7-8.5 $\mu \mathrm{m}$. The ascospore size published by Kurokawa (2001), however, is quite distant from these: $15-18 \times 6-8 \mu \mathrm{m}$. This clearly represents ellipsoid or more probably narrowly ellipsoid ascospores. Apparently, this measurement should be referred to the additional specimens studied, not the types. 



Figure 45. A - Lectotype of Parmotrema reparatum (BM); B and C - holotype of Parmotrema reterimulosum (WU); B - upper surface; $\mathrm{C}$ - undersurface. Scales in milimeters.

Unfortunately, full comparisons of the undersurface of Parmelia reparata and $P$. virens are not possible, since the lectotype of the first species is almost totally glued to a card.

Kurokawa (2001) postulated that $P$. subcaperatum could be endemic to South America, while P. reparatum occurs in Australia and New Zealand. Nevertheless, the specimens at the 'halfway', namely Africa (especially that recorded by Krog \& Swinscow 1981), still need to be revised to corroborate this hypothesis.
The specimens listed in Hale (1965) from the United States of America and Mexico actually belong to P. permaculatum, as already indicated by Hale (1971). The specimens recorded as Canomaculina aff. reparata by Spielmann (2005) need to be checked since they have reticulate maculae and so belong to another species, not P. reparatum.

Distribution. Oceania (Kurokawa 2001). 
Parmotrema reterimulosum (J. Steiner \& Zahlbr.) Spielmann \& Marcelli, comb. nov.

(Fig. 45B-C)

\section{MycoBank MB 838194}

Basionym: Parmelia reterimulosa J. Steiner \& Zahlbr., Botanische Jahrbücher für Systematik, Pflanzengeschichte und Pflanzengeographie 60: 520. 1926.

Type: South Africa. Natal: Drackenberge, Van Reenens Pass, Brunnthaler s.n. (holotype - WU!).

Description (based on holotype). Thallus brownish (herbarium), lobate, apparently loosely adnate, corticicolous, $7 \mathrm{~cm}$ broad. Lobes irregularly branched, laterally overlapped to crowded, 2-5 mm wide, surface continuous or irregularly cracked, smooth or slightly irregular, lustrous, becoming strongly cracked in the center; apical zone rounded; margin sinuous, undulated. Lacinulae absent, although the thallus subdivision could be interpreted as forming lacinulae. Maculae distinct, reticulate, laminal, originating cracks. Cilia black, simple, up to $1.5 \mathrm{~mm}$ long, abundant, at times some 'cilia' (rhizines?) growing in the underside of the lobes. Pustules absent. Soralia whitish, extensive, submarginal and moving on to the center, present also in the apices of the sublacinulae; soredia granular. Isidia absent. Medulla white. Undersurface black, lustrous, rugose or papillate, with scars; marginal zone brown, or dark-brown to black in some areas, lustrous, 1-3 mm wide, naked or with papillate rhizines, with an attenuated limit, smooth to slightly rugose; rhizines black, usually simple, rarely with lateral branches, up to $1.5 \mathrm{~mm}$ long, more or less evenly distributed, in some areas the rhizines are strongly curly and entangled sometimes forming groups of rhizines slightly thickened.

Apothecia pressed down, apparently concave, $1 \mathrm{~mm}$ in diameter, substipitate, laminal, margin smooth crenate, amphithecium strongly rugose, disc dark brown, epruinose, perforate; ascospores ellipsoid or oblong, 12.5-17.5 $\times$ 6-7.5 $\mu \mathrm{m}$, episporium $\sim 1 \mu \mathrm{m}$. Pycnidia laminal to submarginal, conspicuous, without prominent margin, frequent, ostiole black; conidia filiform, 11-16(-18) $\times \sim 1 \mu \mathrm{m}$.

Chemistry. Atranorin (minor), chloroatranorin (trace), salazinic acid (major), consalazinic acid (minor). Cortex $\mathrm{K}+$ yellow, UV-; medulla $\mathrm{K}+$ yellow $\rightarrow$ blood red, $\mathrm{C}-$, $\mathrm{KC}-, \mathrm{P}+$ strong yellow, $\mathrm{UV}-$.

Remarks. Parmotrema reterimulosum is recognized by the soredia ontogeny, the reticulate maculae, the bare marginal zone and the filiform relatively long conidia (11-18 $\mu \mathrm{m})$. This species was described by Zahlbruckner (1926), who made important observations and provided a fully complete description. Dodge (1959) accepted it, citing several additional specimens. Hale \& Fletcher (1990) placed it as a synonym of $P$. reticulatum. However, $P$. reticulatum has a rhizinate under the marginal zone, smaller conidia $8.5-12 \mu \mathrm{m}$ long, and the soredia arise from swellings which become defragmented. In $P$. reterimulosum, the cortex becomes fragmented into minute areolae, which afterwards give rise to the soredia in extensive soralia. Usually, each areola gives rise to only one soredium. The presence of the soralia apparently turns down the lobe apices. The underside marginal zone is papillate or with very rudimentary immature rhizines, or more commonly naked.

The holotype is constituted by a broken thallus (five parts), and a small envelope with one apothecium. Together there is an isidiate, ciliate lichen, probably with stictic acid (medulla $\mathrm{K}+$ yellow).

Distribution. Africa (Zahlbruckner 1926; Dodge 1959).

Parmotrema reticulatum (Taylor) M. Choisy, Bulletin mensuel de la Société Linnéenne de Lyon 21: 175. 1952.

(Figs 2A, 46)

Basionym: Parmelia reticulata Taylor, in Mackay, J.T., Flora hibernica, part second, comprising the Musci, Hepaticae and Lichenes, 1836, p. 148.

Type: Ireland. Kerry: near Dunkerron, on rocks, common, T. Taylor s.n. (lectotype - FH!, isolectotype - BM!).

$\equiv$ Rimelia reticulata (Taylor) Hale \& Fletcher, The Bryologist 93(1): 28. 1990.

= Parmelia praeperlata Nyl., Flora 69: 319. 1886.

Type: French Southern and Antarctic Lands, St. Paul Island, Fenzl s.n. (lectotype - H-NYL 35548!).

Description (based on isolectotype from BM). Thallus slightly brownish, lobate, loosely adnate, over rock with mosses, $6.5-7 \times 4-5 \mathrm{~cm}$ broad. Lobes irregularly branched, crowded, 2-8 mm wide, surface continuous or reticulately cracked, smooth, lustrous, usually cracked in the center; apical zone usually subdivided in lacinulae, when entire rounded; margin smooth, broadly crenate, undulated. Maculae distinct, reticulate, laminal, originating cracks. Lacinulae simple or bifurcate, present in the whole thallus, plane to slightly canaliculated or rarely concave, usually with the apex involute, often covered by soredia, apex acute or sometimes rounded, 0.5-2.2 $\times$ $0.6-1.6 \mathrm{~mm}$. Cilia black, usually simple, rare irregularly branched, squarrose or bifurcated in the apex, $0.1-1 \times$ $0.02-0.05(-0.1) \mathrm{mm}$, few to frequent in the non-sorediate lobes, absent in the sorediate lacinulae. Soralia submarginal, extensive, growing backwards some millimeters in the lamina, becoming labriform in several areas, subapical in the short lacinules; soredia subgranular to farinose, rising from swellings which become fragmentary. Pustules and isidia absent. Medulla white. Undersurface black, lustrous, rugose to veined, with scars; marginal zone brown or rarely black, lustrous, $0.5-3 \mathrm{~mm}$ wide, rhizinate, rugose or papillate, with an attenuated limit; rhizines black, of two extremes: (1) simple to squarrose, slender $(0.02-0.05 \mathrm{~mm}$ wide) and usually shorter $(0.2-1.3 \mathrm{~mm})$, abundant, evenly distributed, or (2) irregularly branched, especially close to the apices, thickened $(0.10-0.25 \mathrm{~mm})$ and longer (0.5-2 mm), frequent, distributed in groups.

Apothecia immature (asci and ascospores not formed), infrequent (four found), urceolate, $3.5 \mathrm{~mm}$ in diameter, substipitate, laminal, margin dentate, sorediate or in process of soredia formation, amphithecium sorediate, disc beige, epruinose, imperforate. Pycnidia laminal to submarginal, conspicuous, without prominent margin, abundant, ostiole black; conidia filiform, $8.5-12 \times \sim 1 \mu \mathrm{m}$. 


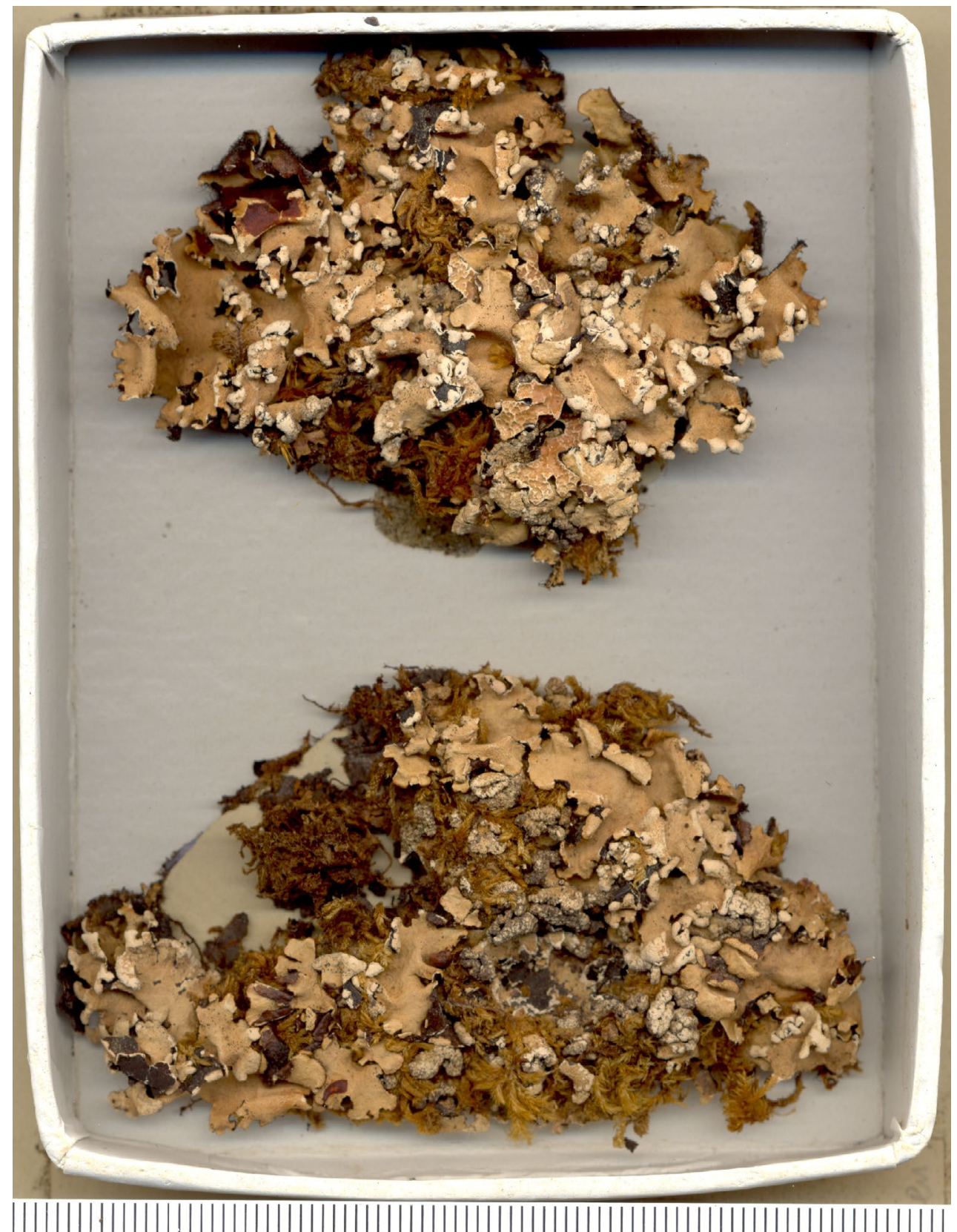

Figure 46. Isolectotype of Parmotrema reticulatum (BM). Scales in milimeters.

Chemistry. Atranorin (minor), chloroatranorin (trace), salazinic acid (major), consalazinic acid (minor). Color tests: cortex $\mathrm{K}+$ yellow, $\mathrm{UV}-$; medulla $\mathrm{K}+$ yellow $\rightarrow$ blood red, $\mathrm{C}-, \mathrm{KC}-, \mathrm{P}+$ strong yellow, $\mathrm{UV}-$.

Remarks. Parmotrema reticulatum is characterized by reticulate maculae, the presence of submarginal, extensive soralia (which also can occur in the short lacinulae) and the production of salazinic acid. It is part of a group of species earlier 'hidden' under Rimelia reticulata. Some very divergent entities were part of this complex, like pustulate species with reticulate maculae ( $P$. granulare), sorediate species with effigurate maculae ( $P$. concors, $P$. lividotessellatum) and pustulate species with effigurate maculae (P. nudum). Also, sometimes included under $P$. reticulatum, $P$. clavuliferum is distinct by the formation of closed lacinulae, sorediate only at the apices.
The rearrangement of the taxa involved lead to the conclusion that the present data on the distribution of $P$. reticulatum cannot be considered reliable, and probably this species has a much more restricted distribution, maybe only in temperate areas of Europe and North America.

Molecular studies shed much more light on this issue, e.g. Divakar et al. (2005), Del-Prado et al. (2011, 2016) and Ahn \& Moon (2016).

Interestingly the apothecia seen in the types are imperforate. According to Hale \& Fletcher (1990), species of Rimelia would always have perforate apothecia. Taylor (1967) also found only imperforate apothecia in Rimelia reticulata. However, Purvis et al. (1992) asserted that they can be sometimes perforate.

The lectotype of $P$. reticulatum $(\mathrm{FH})$ is formed by three pieces glued on a sheet. Although agreeing well with the 
isolectotype, it has structures that can resemble schizidia, since they are areolae that can give rise to soredia at their margins. A reinvestigation is necessary to be sure about these data. Also, since it does not have apothecia or pycnidia, we chose to present here the description of the isolectotype.

The isolectotype of $P$. reticulatum is composed of two thalli glued in a paper box. They are similar in soralia, branching, maculation, and conidia size and shape. There are four immature apothecia. Hale \& Fletcher (1990) asserted that the ascospores of Rimelia reticulata are 13-18 × 8-10 $\mu \mathrm{m}$. However, it is not known from what specimen or specimens these measurements were obtained. The conidia found in the isolectotype are shorter (8.5-12 $\mu \mathrm{m})$ than those cited by Hale \& Fletcher (1990): $12-16 \mu \mathrm{m}$. The soralia in the isolectotype remind Parmotrema simulans (Hale) Hale, which have only atranorin and caperatic acid and was once thought to be a chemotype of P. reticulatum (Hale \& Fletcher 1990).

In the free (not glued) undersurfaces, some thickened rhizines were found, branched and longer in relation to the more common ones. However, a gradual transition between one type to another can be observed.

Parmelia praeperlata Nyl., known only from the type locality, was published by Nylander (1875), and a more complete description was presented some years later (Nylander 1886). It is pertinent to note that Hale \& Fletcher (1990) indicated the paper of Nylander (1886) as the protologue, not Nylander (1875).

The lectotype of $P$. praeperlata has a strong black, marginal line, and sometimes develops short, branched tapering cilia (up to $0.5 \mathrm{~mm}$ ), which are a noticeable feature. However, P. reticulatum also develops a dark brown to black marginal line and similar branched cilia, although just in some lobes. A label by J.A. Elix, dated November 09, 1998, gives the following chemical data: 'TLC solvent C/HPLC: atranorin (minor), chloroatranorin (minor), salazinic acid (major), consalazinic acid (minor)'. Nylander (1886) reported the conidia of Parmelia praeperlata as $9-11 \mu \mathrm{m}$. We found it as $8.5-12 \times \sim 1 \mu \mathrm{m}$. Thus, that is the same size as $P$. reticulatum.

Since apothecia are lacking or immature in the types of $P$. praeperlata and $P$. reticulatum, additional data could not be compared and so it seems better to keep these species as synonyms, until more specimens are available.

Distribution. At this time, the distribution of this species cannot be determined with confidence due to the problems in its specific delimitation.

Parmotrema ruminatum (Zahlbr.) Blanco, Crespo, Divakar, Elix \& Lumbsch, Mycologia 97(1): 158. 2005.

(Fig. 47)

Basionym: Parmelia ruminata Zahlbr. in Magnusson \& Zahlbruckner, Arkiv för Botanik 31A(6): 107. 1944.

Type: Hawaiian Islands: 200 feet alt. $(656 \mathrm{~m})$, Brother Matthias 757 (lectotype - W! selected here, MycoBank MBT 395071).

三 Rimelia ruminata (Zahlbr.) Hale \& Fletcher, The Bryologist 93(1): 28. 1990.
= Parmelia ramescens Zahlbr. in Magnusson \& Zahlbruckner, Arkiv för Botanik 31A(6): 97. 1944.

Type: Hawaii: Maui, Iao Valley, Faurie 516 (lectotype - W!; isolectotypes - BM!, PC).

$\equiv$ Rimelia ramescens (Zahlbr.) K.H. Moon \& Kurok., Journal of Japanese Botany 76: 326. 2001.

Description (based on lectotype). Thallus brownish (herbarium), lobate, $10.5 \mathrm{~cm}$ broad. Lobes irregularly branched, \pm crowded, 2-5 mm wide, surface continuous to cracked, slightly rugose or irregular, becoming strongly rugose, cracked and pustulate towards the center, sometimes producing areolae that flake off; apical zone rounded, usually pruinose; margin smooth to sinuous or sublobulate, undulated. Maculae distinct, reticulate, laminal, originating cracks. Cilia absent to rare (see comments below). Pustules rugose, capitate or elongated, laminal, remaining entire or sometimes flaking off together with the areolae. Lacinulae, soralia and isidia absent. Medulla white. Undersurface black, lustrous, smooth to rugose, with cracks; marginal zone brown, lustrous, 1-2 mm wide, naked, with an attenuated limit, smooth; rhizines black, simple, up to $1 \mathrm{~mm}$ long, 0.01-0.04 mm wide.

Apothecia cupuliform, 1-4 mm in diameter, short-stipitate, laminal, margin crenate, pustulate, amphithecium rugose, pustulate, disc brown, epruinose, imperforate; ascospores oblong-ellipsoid, 16-20 × 7.5-9 $\mu \mathrm{m}$, episporium 1-1.5 $\mu \mathrm{m}$. Pycnidia submarginal, conspicuous, usually without prominent margin, few, ostiole black; conidia filiform, $9-13 \times \sim 1 \mu \mathrm{m}$.

Chemistry (TLC in solvent C, HPLC, J. Johnston \& G.A. Jenkins, 03.II.1988, label with the lectotype in W). Atranorin, chloroatranorin, salazinic acid (major), consalazinic acid (trace), protocetraric acid (trace), unknown RT 5.81 (trace, HPLC only). Cortex K+ yellow, UV-; medulla K+ yellow $\rightarrow$ blood red, $\mathrm{C}-$, $\mathrm{KC}-$, $\mathrm{P}+$ strong yellow, $\mathrm{UV}-$.

Remarks. Parmotrema ruminatum is characterized by the strongly pustulate upper surface, from which sometimes areolae are flaked off, and the eciliate lobe margins. It is related to $P$. austrocetratum, in which the production of areolae is much more evident, giving rise to schizidia, and the cilia are abundant and longer (up to $1.6 \mathrm{~mm}$ ).

The lectotype of P. ruminatum is well-developed and shows all features necessary for its description, except the undersurface, since the thallus is strongly glued to a paper card. Although a greenish fungus is abundant in the upper surface, it seems that it is not causing any damage to the thallus. Rare black, simple cilia, 0.1-0.6 $\times 0.02-0.05 \mathrm{~mm}$ were found. These look much more like an 'accident' (some rhizinate growing in the margin) than true cilia, and so the species is considered eciliate here.

The ascospores of this species, oblong-ellipsoid, are quite uncommon in the Parmotrema with salazinic acid. That is so strange that we first thought the measurements described in Magnusson \& Zahlbruckner (1944) could be wrong, but confirmation through the lectotype study then confirmed their data.

The typification revealed some problems. Magnusson \& Zahlbruckner (1944) listed two collections, one from 


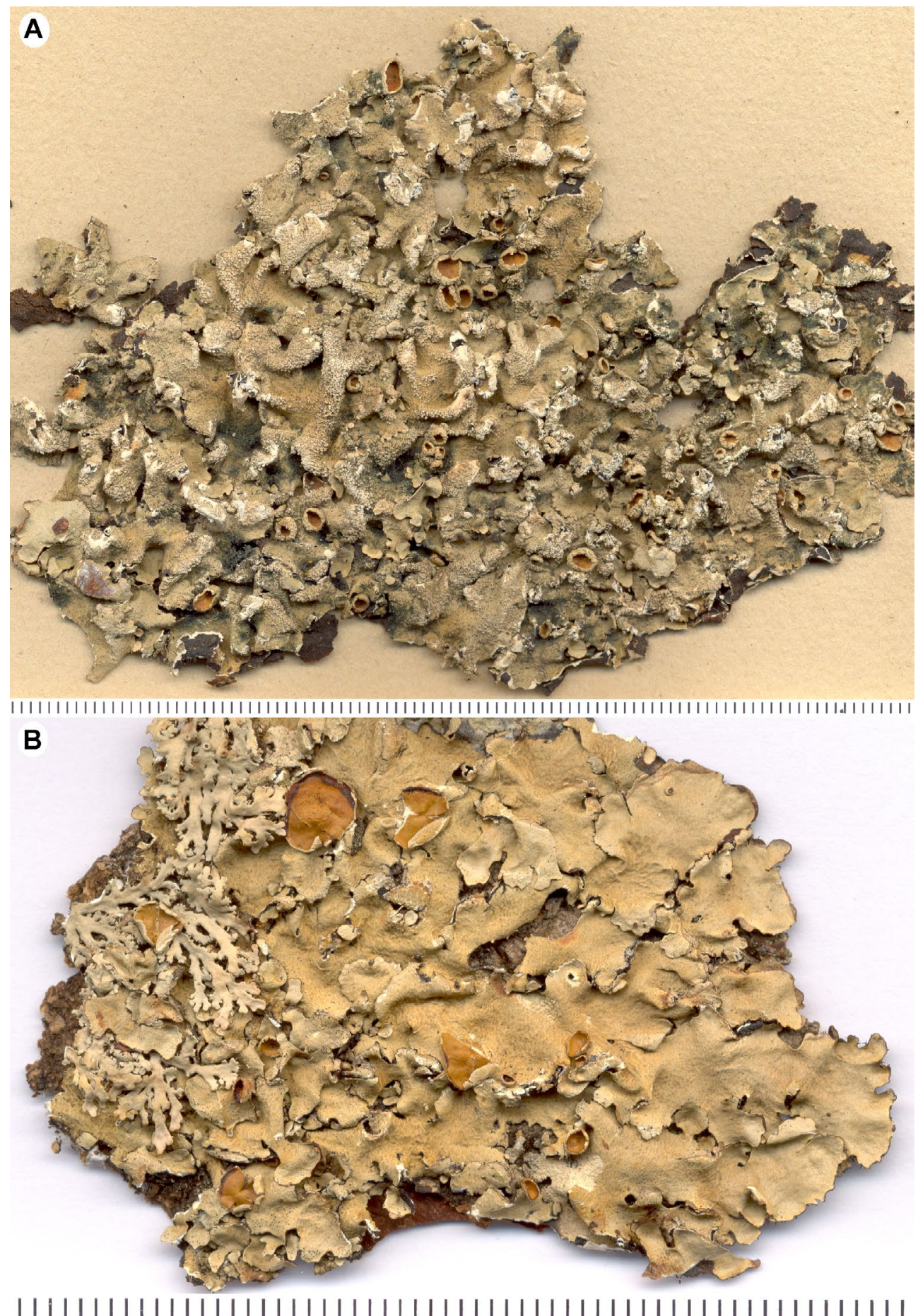

Figure 47. A - lectotype of Parmotrema ruminatum (W); B - holotype of Parmotrema ruptum (S). Scales in milimeters.

the Hawaiian Islands (Brother Matthias) and one from Hawaii (Faurie 861). According to a label from Hale (dated 1965), the specimen Brother Matthias 757 (W) is the holotype. However, Hale \& Fletcher (1990) chose as lectotype 'Brother Matthias (Faurie 861), Hawaii'. We do not know where the specimen Faurie 861 is preserved, and future studies must trace it to clarify its status. Thus, for practical purposes, the specimen Brother Matthias 757 is here being selected as lectotype.

Both the lectotype and isolectotype of Parmelia ramescens are well-developed thalli, the specimen from $\mathrm{W}$ being $10 \mathrm{~cm}$ broad and the $\mathrm{BM}$ specimen
$13 \mathrm{~cm}$ broad. The upper surface is strongly rugose and pustulate, and some lobes become canaliculated. In the other features, they agree well with the holotype of $P$. ruminata, and so are here being treated as its synonym, a position already proposed by Hale \& Fletcher (1990). Zahlbruckner (in Magnusson \& Zahlbruckner 1944) asserted that he saw a large thallus up to $20 \mathrm{~cm}$ broad. Maybe this is the specimen deposited in PC, though we have not seen it.

Conidia were found only in the isolectotype of P. ramescens $(\mathrm{BM})$. They are filiform, 9-14 $\times \sim 1 \mu \mathrm{m}$, so matching the conidia of $P$. ruminata. 
Moon et al. (2001) described Rimelia ramescens as a distinct species. Those authors asserted that it has 'a rather smooth upper surface' and 'it lacks pustules and eminent ridges'. That observation, however, does not agree with ours, made on the lectotype and its duplicate. They may refer to the additional specimen examined by those authors. The herbarium where the lectotype is hosted is actually W, not TNS, as referred to by those authors.

Parmotrema ruminatum has an indeterminate substrate. It was quoted as 'saxicolous?' by Magnusson \& Zahlbruckner (1944), corticicolous by Moon et al. (2001) and finally both in Smith (1993). The last author, nevertheless, asserted that the species is schizidiate, not pustulate, and so his identification needs to be confirmed.

Distribution. Hawaiian Islands (Magnusson \& Zahlbruckner 1944; Smith 1993; Hale \& Fletcher 1990; Moon et al. 2001).

Parmotrema ruptum (Lynge) Hale ex DePriest \& B. Hale, Mycotaxon 67: 204. 1998

(Fig. 47B)

Basionym: Parmelia rupta Lynge, Arkiv för Botanik 13(13): 40. 1914. Type: Paraguay. Gran Chaco: ad Rio Negro, 14.IX.1893, corticicolous, G.O.A. Malme (holotype - S!).

Description (based on holotype). Thallus brownish (herbarium), lobate, \pm adnate, corticicolous, $6 \mathrm{~cm}$ broad. Lobes irregularly branched to quite crowded in the center, 2-7 mm wide, surface continuous or reticulately cracked, smooth to irregular, lustrous, becoming fully reticulately cracked towards the center; apical zone rounded; margin smooth to sublacinulate or lobulate (see comments), undulated. Maculae distinct, reticulate to hypermaculate, laminal, originating cracks. Cilia black, simple or rarely furcated near the apex, short, up to $0.5 \mathrm{~mm}$ long, usually thin, but sometimes thickened, $0.02-0.1 \mathrm{~mm}$ wide, few. Sublacinulae or lobules simple, few, plane, apex usually acute to rounded, rarely truncate, $0.2-2 \times 0.2-1 \mathrm{~mm}$. Pustules, soredia and isidia absent. Medulla white. Undersurface black, lustrous, rugose, subscrobiculate, papillate or veined, with cracks; marginal zone dark brown to dark reddish brown, lustrous, $0.5-2 \mathrm{~mm}$ wide, naked, with an attenuated limit, smooth to slightly rugose; rhizines black, usually simple, up to $1 \mathrm{~mm}$ long, thin to thickened, $0.02-0.15 \mathrm{~mm}$ wide, abundant, evenly distributed.

Apothecia plane to concave or cupuliform, $1.5-5.5 \mathrm{~mm}$ in diameter, short-stipitate, usually submarginal, margin smooth, crenate or deeply incised, dividing the apothecium in parts, rarely with small lobules, amphithecium maculate, smooth or rugose, disc pale brown, epruinose, usually rugose at maturity, imperforate although with a central depression; ascospores subglobose to ellipsoid, biserial, $10-12.5 \times 6-7.5 \mu \mathrm{m}$, episporium $\sim 1 \mu \mathrm{m}$. Pycnidia submarginal or laminal, conspicuous, with or without prominent margin, abundant, ostiole black; conidia filiform, $10-12.5 \times \sim 1 \mu \mathrm{m}$.

Chemistry (TLC in solvent C, HPLC, J.A. Elix, 28.XII.2007, label with the holotype). Atranorin (minor), chloroatranorin (minor), salazinic acid (major), consalazinic acid (minor). Cortex $\mathrm{K}+$ yellow, $\mathrm{UV}-$; medulla $\mathrm{K}+$ yellow $\rightarrow$ blood red, $\mathrm{C}-, \mathrm{KC}-, \mathrm{P}+$ strong yellow, UV-.

Remarks. Parmotrema ruptum can be recognized by the strongly reticulately cracked upper surface, associated with reticulate maculae (sometimes hypermaculate), the absence of propagules, the short, rare cilia, the naked under margin, usually dark reddish-brown, and the production of salazinic acid. Fleig (1997) considered $P$. ruptum and $P$. expansum synonyms of $P$. eurysacum. However, according to the types studied, $P$. eurysacum is emaculate, and $P$. expansum has effigurate maculae. It also could be confused with $P$. cetratum, which is distinctly rhizinate up to the margin.

The specimens recorded by Canêz (2005) as Parmotrema ruptum were studied (SP). They are represented by well-developed thalli. In fact, one thallus is $22 \mathrm{~cm}$ broad. The upper surface is usually strongly maculate (hypermaculate) and whitish, resembling $P$. albinatum, a sorediate species recently described from Hawaii (Moon et al. 2001), although in some lobes the reticulate maculae are conspicuous. The cilia are quite frequently long (up to $1 \mathrm{~mm}$ ) and bifurcate, and the thallus is almost uniformly whitish. Nevertheless, the underside is practically identical to the holotype of $P$. ruptum, especially the dark reddish-brown under margin and rugose surface. The conidia also are equal. Thus, the especimens studied by Canêz (2005) really represent Parmotrema ruptum.

It must be noted that all specimens recorded by Canêz (2005) are saxicolous, while the holotype of P. ruptum is corticicolous. Unfortunately, the specimens reported by Canêz (2005) did not develop apothecia, impeding the comparison of ascospores data.

The holotype of P. ruptum is attached to a piece of bark, so some the undersurface features were not described in detail, the observations being based only on the free lobes. The thallus also forms some adventitious lobules or sublacinulae, rose on the damaged areas. In future collections of this species, special attention must be paid in these structures (if present) and also on apothecial margins. They are quite similar to the lobe margins and may give rise to apothecial cilia.

Distribution. Bolivia (Flakus et al. 2016), Brazil (Canêz 2005), Paraguay (Lynge 1914; Hale 1960) and Uruguay (Räsänen 1938; Osorio 1972).

Additional specimens examined. BRAZIL. Rio Grande do Sul: Municipality of Vacaria, Fazenda da Estrela, 28 $04^{\prime} 49.2^{\prime \prime} \mathrm{S}$, $50^{\circ} 56^{\prime} 36.9^{\prime \prime} \mathrm{W}, 850 \mathrm{~m}$, over basaltic rock, sunny place, 10.I.2004, L.S. Canêz \& A.A. Spielmann 1020, 1021, 1035, 1080 (SP).

Parmotrema sieberi (C.W. Dodge) Spielmann \& Marcelli, comb. nov.

(Fig. 48)

MycoBank MB 838195

Basionym: Parmelia sieberi C.W. Dodge, Annals of the Missouri Botanical Garden 46: 148. 1959.

Type: Mauritius. Sieber, Crypt. Exot. 44, corticole, ex herb. Sbarbaro (holotype - FH!; isotype - FH!). 
= Parmelia claudelii var. clemensae Vain., Philippine Journal of Science. 4: 659. 1909.

Type: Philippines. Mindanao: Lake Lanao, Clemens 1319 (lectotype - TUR, Vainio herb. $\mathrm{n}^{\circ} 2542$ !).

Description (based on holotype). Thallus brown, lobate, loosely adnate, apparently corticicolous, $45 \mathrm{~cm}$ broad. Lobes irregularly branched, laterally overlapped, 8-25 mm wide, surface continuous or less frequently cracked, usually smooth, lustrous, becoming rugose and cracked in the center; apical zone rounded; margin smooth or sparsely crenate, undulated. Cilia black, simple or furcated, sometimes more branched, up to $2 \mathrm{~mm}$ long, frequent, less dense in the lobe apices. Maculae absent. Soralia usually concolor to the thallus or more pale, linear continuous or interrupted, sometimes with a tendency to become extensive or labriform, or then orbicular in the apex of small lateral growths (lacinulae?), usually marginal, rarely laminal, in apothecial
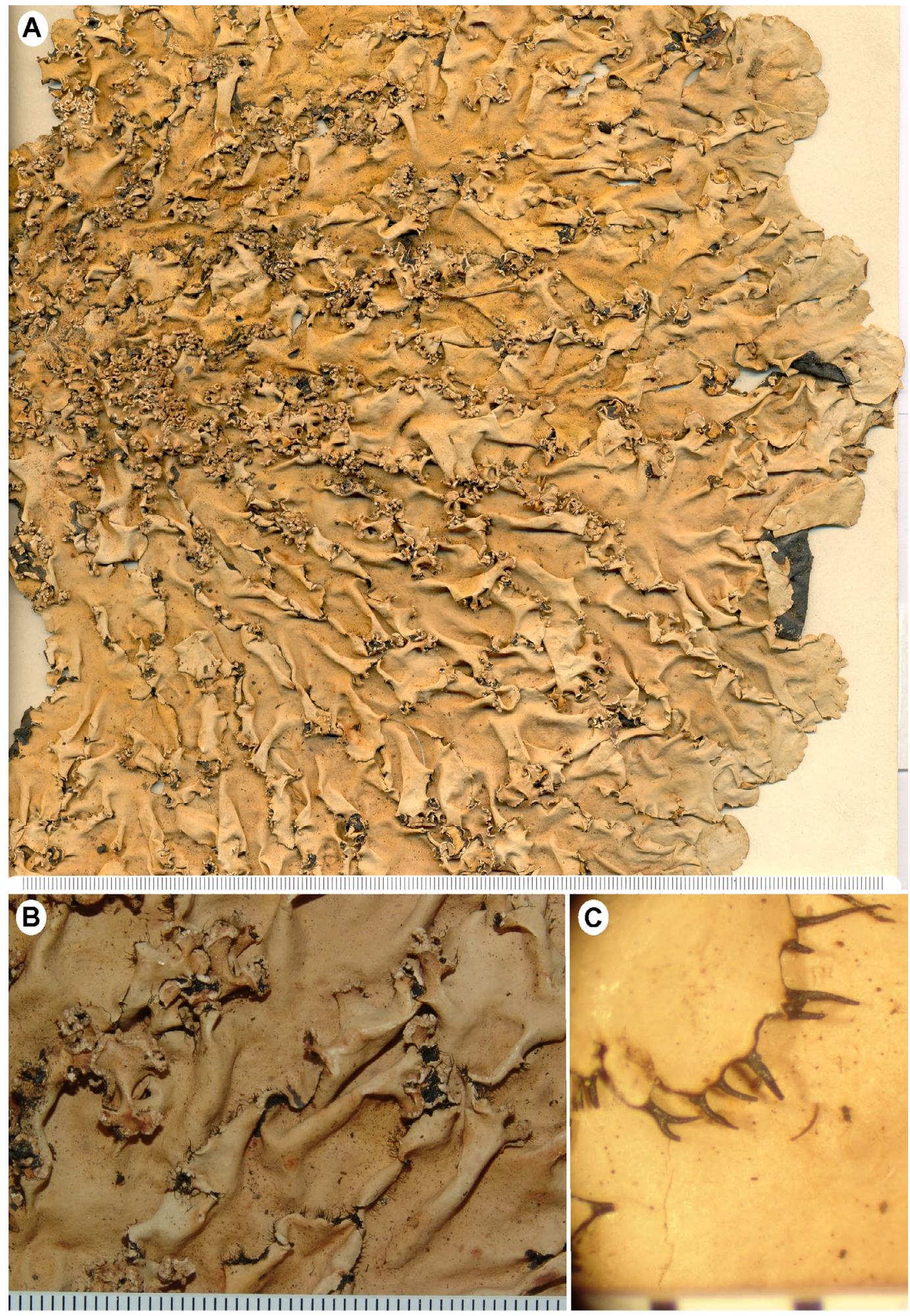

Figure 48. Holotype of Parmotrema sieberi (FH). A - thallus; B - ciliate lobes; C - cilia. Scales in milimeters. 
primordia; soredia granular. Lacinulae, isidia and pustules absent. Medulla white. Undersurface black, lustrous, smooth to rugose or papillate, with scars; marginal zone brown, lustrous, 3-12 mm wide, naked, with an attenuated limit, smooth, rugose or papillate, sometimes veined; rhizines black, simple, up to $1 \mathrm{~mm}$ long, frequent, distributed in groups.

Apothecia concave/ cupuliform, up to $3 \mathrm{~mm}$ in diameter, stipitate, laminal, margin sorediate, amphithecium sorediate, disc dark brown, epruinose, imperforate; epithecium 10-12 $\mu \mathrm{m}$; hymenium 30-34 $\mu \mathrm{m}$; subhymenium 12-14 $\mu \mathrm{m}$; ascospores ellipsoid, 25-28 × 15-18 $\mu \mathrm{m}$, episporium 2-3 $\mu \mathrm{m}$. Pycnidia laminal, conspicuous, without prominent margin, few, ostiole black; conidia not found ( $\sim 30$ pycnidia investigated).
Chemistry. Atranorin (minor), chloroatranorin (trace), salazinic acid (major), consalazinic acid (minor). Cortex $\mathrm{K}+$ yellow, $\mathrm{UV}-$; medulla $\mathrm{K}+$ yellow $\rightarrow$ blood red, $\mathrm{C}-$, $\mathrm{KC}-, \mathrm{P}+$ strong yellow, $\mathrm{UV}-$.

Remarks. Parmotrema sieberi is characterized by the sorediate thallus with wide lobes $(8-25 \mathrm{~mm})$, and simple to furcated cilia, up to $2 \mathrm{~mm}$ long. It is very similar to $P$. cristiferum, the differences being the presence of well-developed cilia (absent in P. cristiferum), wider lobes, soralia not so crisped and the absence of eumitrins. These features seem suitable for species separation at the present. On the other hand, the ascospores are similar. Besides, one of the specimens determined as P. sieberi by Dodge (Mauritius, Wight s.n., FH!), actually the
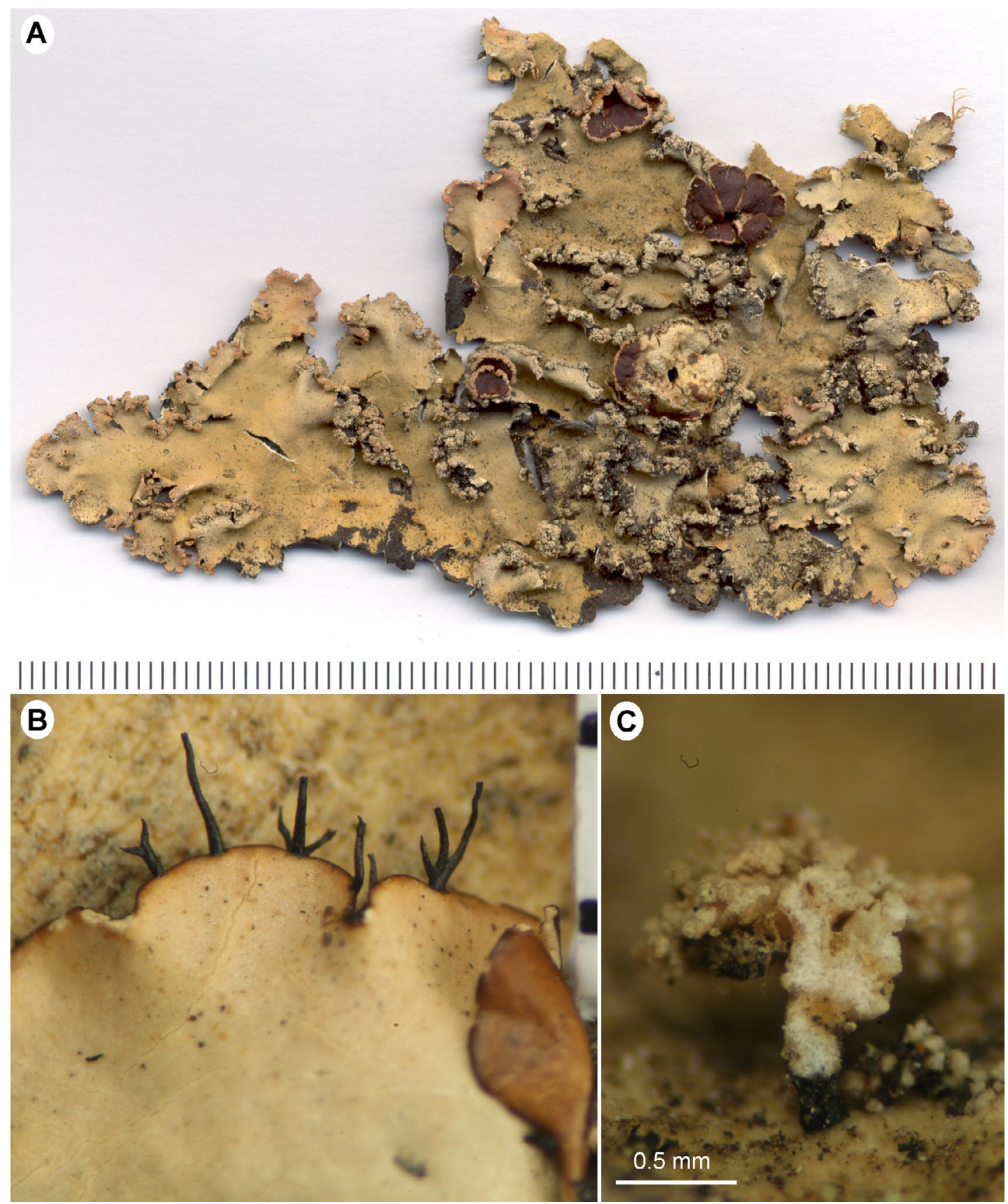

Figure 49. Parmotrema spinibarbe. A - holotype (TNS); B - holotype, showing cespitose cilia; C - isotype (G), showing the botryose structure. Scales in milimeters or as indicated. 
isolectotype of Parmelia cristifera, has sublageniform conidia, 5-7 $\times \sim 1 \mu \mathrm{m}$, equal to that described for Parmelia cristifera (see Vainio 1909a). The chemistry of both species is also the same.

If we consider $P$. sieberi as a synonym of $P$. cristifera, we must accept that Parmelia cristifera could produce well-developed cilia. Krog \& Swinscow (1981) already pointed out that occasional, rudimentary cilia could grow in the lobe axils of $P$. cristifera. In P. sieberi, however, the cilia are very well-developed, seen by the unaided eye.

Krog and Swinscow (1981) asserted that the holotype of $P$. sieberi was a collection from Wight, at Mauritius (FH). Elix, in a label, did the same. The true holotype, however, is 'Mauritius, Sieber, Crypt Exot. 44, corticole, ex herb. Sbarbaro, at Farlow Herb.', as indicated in the protologue (Dodge 1959), by a label from Dodge dated 1957 and another one from Kurokawa dated 1967.

There is also an isotype in FH, smaller than the holotype. It has very few cilia and more crisped soralia; thus, it is more adequately treated as Parmelia cristifera. Unfortunately, pycnidia were not found.

The absence of pycnidia in the lectotype of Parmelia cristifera and in the holotype and isotype of Parmelia sieberi leaves a gap, which can be filled, hopefully, with the study of additional collections.

The lectotype of Parmelia claudelii var. clemensae Vain. agrees in gross morphology, and conidia (sublageniform, 6-9 $\times \sim 1 \mu \mathrm{m}$ ) with $P$. cristiferum, although also presents well-developed cilia and the chemistry is identical with that of $P$. sieberi, and so is accepted here as a synonym of this last species.

Distribution. Africa (Dodge 1959) and Philippines (Vainio 1909b).

Parmotrema spinibarbe (Kurok.) Hale ex DePriest \& B. Hale, Mycotaxon 67: 204. 1998.

(Fig. 49)

Basionym: Parmelia spinibarbis Kurok., Bulletin of the National Science Museum Tokyo 17(4): 299. 1974.

Type: Brazil. Rio de Janeiro: Petrópolis, about $810 \mathrm{~m}$ alt., on trees, July 17, 1971, S. Kurokawa 8348 (holotype - TNS!; isotypes - DUKE!, G!, O!, US!, W!).

Description (based on holotype). Thallus brownish (herbarium), lobate, loosely adnate, corticicolous, $8-11 \mathrm{~cm}$ broad. Lobes irregularly branched, laterally overlapped, 3-15 mm wide, surface smooth to more often strongly cracked, especially at old parts, rather opaque; apical zone \pm rounded; margin crenate to usually incised, undulated. Maculae usually strong, although difficult to see at the first sight, since it covers almost all the upper surface, punctiform to effigurate, sometimes assuming a pseudoreticulate pattern (by the confluence of the dots), laminal, not originating cracks (as normally occur with real reticulate maculae). Cilia black, simple to more commonly cespitose, $0.5-1.5 \times 0.02-0.1 \mathrm{~mm}$, abundant, apparently friable, since the upper surface is abundantly covered by pieces of cilia. Soralia marginal, somewhat extensive toward the center of the thallus, or forming both laminal and marginal botryose structures fully covered by soredia; soredia granular. Lacinulae, pustules and isidia absent.
Medulla white. Undersurface black, lustrous, papillate or rugose, with many cracks; marginal zone brown (sometimes absent), lustrous, $0.5-2 \mathrm{~mm}$ wide, naked, with a sharp limit, smooth to slightly rugose or less frequently papillate; rhizines black, simple, $0.3-1.5 \times 0.02-0.1 \mathrm{~mm}$, abundant, distributed in groups.

Apothecia plane or concave, 3-10 $\mathrm{mm}$ in diameter, shortly stipitate, laminal, margin sorediate, amphithecium maculate, sorediate, disc dark brown, epruinose, perforate at maturity; ascospores ellipsoid to broadly ellipsoid, $12-13.5 \times 7-9 \mu \mathrm{m}$, episporium 1-1.5 $\mu \mathrm{m}$. Pycnidia submarginal, conspicuous, without or with a slightly prominent margin, abundant, ostiole black; conidia filiform, $7.5-10 \times \sim 1 \mu \mathrm{m}$.

Chemistry (TLC in solvent C, HPLC, J.A. Elix, 17.VII.1996, label with the holotype in TNS). Atranorin (minor), chloroatranorin (minor), lichexanthone (major), salazinic acid (major), consalazinic acid (trace). Cortex $\mathrm{K}+$ yellow, $\mathrm{UV}-$; medulla $\mathrm{K}+$ yellow $\rightarrow$ blood red, $\mathrm{C}-$, $\mathrm{KC}-, \mathrm{P}+$ strong yellow, $\mathrm{UV}+$ yellow.

Remarks. Parmotrema spinibarbe is characterized by the presence of cespitose cilia, and the marginal and less frequently laminal soredia, sometimes growing from botryose structures. In $P$. pontagrossense, otherwise similar in the cilia branching, cortical chemistry and conidial form and size, the botryose structures are absent from the examined type material (holotype, UPCB, isotype in BAFC). Additionally, it produces lichesterinic and protolichesterinic acids in the medulla. Unfortunately, apothecia are unknown in this species, and so we cannot compare ascospore data. Parmotrema diffractaicum is morphologically very similar to $P$. spinibarbe, as already noted by Fleig (1997) and Canêz (2005). Chemically, however, they are distinct since $P$. diffractaicum produces diffractaic acid instead of salazinic acid.

The holotype of $P$. spinibarbe (TNS) is in very good condition and has conidia and apothecia. All other isotypes examined agree with the holotype in every aspect. However, some notes can be added: (1) the botryose structures are much more abundant in the isotype from $\mathrm{G}$; (2) the isotype from $\mathrm{O}$ has the upper cortex damaged in some lobes that resulted in the production of many orbicular atypical soralia; additionally, the marginal cilia are almost entirely cespitose; (3) a well-developed perforate apothecium and many botryose structures were observed in the isotype from US that had already been examined by S. Eliasaro \& M. Adler (label dated 1997); (4) the isotype from W also developed abundant botryose structures, and the upper cortex is injured in some lobes, though the soralia is not so well-developed.

Within the additional specimens examined, two of them did not develop the botryose structures (Spielmann 1348 and 1350), being probably young thalli. The latest (Spielmann 1350) also has the apices of some lobes pruinose. The specimen Spielmann 4920 is $33 \mathrm{~cm}$ long, the largest thallus found.

Distribution. Known only for Brazil, being recorded from Paraná, Rio de Janeiro (Kurokawa 1974), Rio 
Grande do Sul (Fleig 1997; Canêz 2005; Spielmann 2005), Santa Catarina (Fleig 1997) and São Paulo (Fleig 1997; Ribeiro 1998; Benatti 2005).

Additional specimens examined. VENEZUELA. Táchira: Vía Villa Paez-Betania, valley of Páramo de Tama, open rocky pastures, 2000-2300 m, 25 March 1975, M.E. Hale \& M. López Figueiras 45185, 45191 (US). BRAZIL. Rio Grande do Sul: Municipality of Boqueirão do Leão, Linha Sinimbuzinho, Perau da Nega, $29^{\circ} 20^{\prime} 17.2^{\prime \prime} \mathrm{S}, 52^{\circ} 26^{\prime} 33.6^{\prime \prime} \mathrm{W}, 430 \mathrm{~m}$ alt., saxicolous, open place, near the waterfall., 23.II.2004, A.A. Spielmann \& L.S. Canêz 1348, 1349, 1350 (SP). Idem, Municipality of Santa Cruz do Sul, near the Residencial Costa Norte, $29^{\circ} 41^{\prime} 25.3^{\prime \prime} \mathrm{S}, 52^{\circ} 26^{\prime} 19.3^{\prime \prime} \mathrm{W}, 100 \mathrm{~m}$ alt., corticicolous, on forest border, 26.VI.2004, A.A. Spielmann 1168, 1171, 1172, 1200 (SP). Santa Catarina: Papanduva, Serra do Espigão, 1000 m alt., epífito em mata, 10.VII.1962, Reitz \& Klein 13063 (US). São Paulo: Municipality of Mogi-Mirim, Estação Experimental do Instituto Florestal, corticicolous, border of Cerradão vegetation, 14.V.2004, A.A. Spielmann, M.P. Marcelli, P. Jungbluth \& M.N. Benatti 4920 (SP).

Parmotrema stuppeum (Taylor) Hale, Phytologia 28(4): 339. 1974.

(Fig. 50A)

Basionym: Parmelia stuppea Taylor, London Journal of Botany 6: 175. 1847.

Type: USA California: Monterey, Beechy [not 'Beechey'] (holotype - FH!; isotypes - BM!, K).

Description (based on holotype). Thallus brownish (herbarium), lobate, apparently loosely adnate, $4 \mathrm{~cm}$ broad. Lobes irregularly branched, crowded, 3-7 mm wide, surface extensively cracked; apical zone rounded; margin smooth to dentate, undulated. Maculae apparently present in some areas, barely distinct and difficult to interpret because of the thallus state of preservation, maybe punctiform or effigurate. Cilia absent (only something similar to one cilium was found, black, $\sim 0.5 \mathrm{~mm}$, simple). Lacinulae, pustules and isidia absent. Soralia marginal or extensive; soredia farinose. Medulla white. Undersurface black and with abundant reddish brown stains, lustrous, strongly venate, naked, with scars; marginal zone black or with brown stains, naked, with veined; rhizines black, seen only through one hole in the thallus where somebody made a spot test (possibly Hale).

Apothecia plane or more usually concave, up to $7 \mathrm{~mm}$ in diameter, short-stipitate, laminal, margin smooth, crenate or with deep incisions, sorediate, amphithecium usually sorediate, disc dark brown, probably paler when freshly collected, epruinose, imperforate, often cracked; ascospores not formed or immature (Hale 1965 reported ascospores with 12-17 × 6-9 $\mu \mathrm{m}$, episporium 1-1.5 $\mu \mathrm{m})$. Pycnidia absent (according to Hale 1965, conidia 4-6 $\mu \mathrm{m}$ long).

Chemistry. Atranorin (minor), chloroatranorin (trace), salazinic acid (major), consalazinic acid (minor). Cortex $\mathrm{K}+$ yellow, $\mathrm{UV}-$; medulla $\mathrm{K}+$ yellow $\rightarrow$ blood red, $\mathrm{C}-$, $\mathrm{KC}-, \mathrm{P}+$ strong yellow, $\mathrm{UV}-$.

Remarks. Parmotrema stuppeum is recognized by the strictly marginal soralia, absent lacinulae, sublageniform conidia and the medium sized ascospores $(12-17 \times 6-9 \mu \mathrm{m}$ according to Hale 1965). It is close to $P$. cristiferum, that has larger ascospores $(24-35 \times 12-20 \mu \mathrm{m})$. Another similar species is $P$. maximum, differentiated by the sorediate lacinulae.

The holotype of $P$. stuppeum in FH is probably not very representative of the species (see Hale 1965) and the same can be said about the isotype from BM. Ascospores and conidial data could not be obtained. Taylor (1847) did not provide microscopic data. The description by Hale (1965) of a ciliate specimen reported ascospores $12-17 \times 6-9 \mu \mathrm{m}$, episporium 1-1.5 $\mu \mathrm{m}$, and conidia 4-6 $\mu \mathrm{m}$ long. However, it is not clear which specimen was studied by Hale to obtain these data, whether from the type of P. stuppea or from the type of $P$. maxima (since that was the type illustrated!), or from additional specimens examined.

There is a label from Berry (E.C.B), dated from July 02, 1937, asserting that the specimen in $\mathrm{FH}$ could be the type of Parmelia stuppea. However, in his publication (Berry 1941), he placed Parmelia stuppea as belonging to Lecanora.

Some published pictures of Parmotrema stuppeum, like that of Hale (1979) and Brodo et al. (2001), show the strictly marginal soredia not occurring in lacinulae. This concept agrees with Hale (1965: 291), where he clearly stated that Parmelia stuppea lacks distinct lacinulae (as 'laciniae'). On the other way, the conidia and ascospores data available need to be revised. The data about them included by Nash \& Elix (2002b) are exactly the same provided by Hale (1965), with the addition of the feature 'sublageniform' to the conidia.

Distribution. North America (Hale 1965; Brodo et al. 2001; Nash \& Elix 2002b; Egan et al. 2016), Central America (Hale 1965), Africa (Hale 1965) and Asia (Divakar \& Upreti 2005), Europe (Hale 1965)/

Parmotrema subcaperatum (Kremp.) Hale, Phytologia 28(4): 339. 1974.

(Fig. 50B)

Basionym: Parmelia subcaperata Kremp., Videnskabelige meddelelser fra Dansk naturhistoriske Forening i Kjöbenhavn 5: 10.1874.

Type: Brazil: [Minas Gerais: Municipality of Caeté], Serra da Piedade, ad truncos arborum, Warming 297 (holotype - M!).

$\equiv$ Rimeliella subcaperata (Kremp.) Kurok., Annals of the Tsukuba Botanical Garden 10: 7. 1991.

三 Canomaculina subcaperata (Kremp.) Elix, Mycotaxon 65: 477.1997.

= Parmelia imperforata Nyl., Acta Societates Scientiarum Fennicae 26(10): 7. 1899.

Type: Brazil. 1871, Glaziou 1839 (holotype - H-NYL 35425).

Description (based on holotype). Thallus brownish (herbarium), lobate, loosely adnate, corticicolous, $4 \mathrm{~cm}$ broad. Lobes irregularly branched, crowded, 3-7 mm wide, surface continuous, smooth to subfoveolate, lustrous, becoming rugose, cracked and foveolate towards the center; apical zone rounded; margin crenate to irregular or sublacinulate, plane to undulated. Maculae distinct or sometimes weak, effigurate, laminal, originating cracks or not. Cilia black, simple and apparently also rarely furcated, up to $1.5 \mathrm{~mm}$ long, quite thickened, $0.04-0.1 \mathrm{~mm}$ 

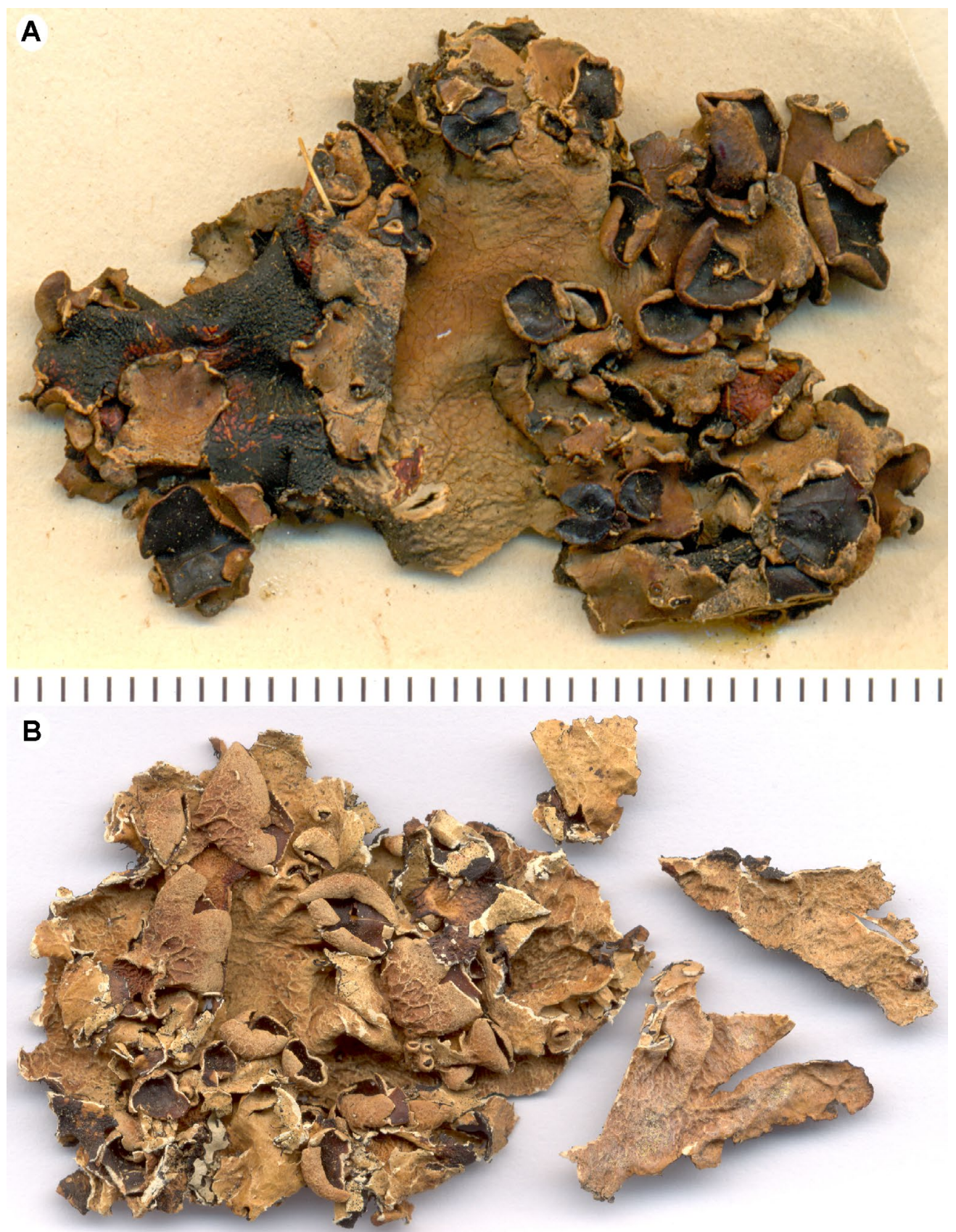

\section{||||||||||||||||||||||||||||||||||||||||||||||||||||||||}

Figure 50. A - holotype of Parmotrema stuppeum (FH); B - holotype of Parmotrema subcaperatum (M). Scales in milimeters.

wide, few. Lacinulae, pustules, soredia and isidia absent. Medulla white. Undersurface black or brown blackish, opaque, slightly rugose or papillate, with cracks; marginal zone dark brown or brown, opaque to lustrous, 3-10 $\mathrm{mm}$ wide, naked or rhizinate, with an attenuated limit, smooth to papillate or veined; rhizines black, dimorphic, the shorter ones simple, up to $1 \mathrm{~mm}$ long, thin, $0.02-0.05 \mathrm{~mm}$ wide, few, irregularly distributed, the longer ones up to $2 \mathrm{~mm}$ long, thickened, $0.05-0.1 \mathrm{~mm}$ wide, simple or irregularly branched near the apices, frequent, irregularly distributed.

Apothecia cupuliform, up to $8 \mathrm{~mm}$ in diameter, substipitate, laminal or submarginal, margin incised to lacerate, usually involute, amphithecium maculate, strongly rugose and foveolate when mature, disc dark brown to blackish, epruinose, perforate at maturity; ascospores ellipsoid, 14-16 × 9-11 $\mu \mathrm{m}$, episporium 1-1.5 $\mu \mathrm{m}$. Pycnidia submarginal to less frequently laminal, conspicuous, without prominent margin, abundant, ostiole black; conidia not found ( $\sim 30$ pycnidia examined).

Chemistry (HPLC, J.A. Elix, 23.VII.1997, label with the holotype). Atranorin (minor), usnic acid (minor), salazinic acid (major), consalazinic acid (trace). Cortex $\mathrm{K}+$ yellow, $\mathrm{UV}-$; medulla $\mathrm{K}+$ yellow $\rightarrow$ blood red, $\mathrm{C}-$, $\mathrm{KC}-$, $\mathrm{P}+$ strong yellow, UV-.

Remarks. Parmotrema subcaperatum is characterized by the effigurate maculae, dimorphic rhizines, absence of propagules and the widely black or brown-blackish 
Table 2. Main characters of Parmotrema subcaperatum and P. erubescens (from Elix 1997).

\begin{tabular}{|c|c|c|}
\hline Characteristic & Parmotrema subcaperatum & Parmotrema erubescens \\
\hline Substrate & saxicolous or rarely corticicolous & corticicolous \\
\hline Thallus & membranaceous & coriaceous \\
\hline Habitat & temperate & subtropical and tropical \\
\hline Lower surface & $\begin{array}{l}\text { black to the margins or marginal zone dark brown, } \\
\text { narrow and naked }\end{array}$ & $\begin{array}{l}\text { with a broad and brown marginal zone, papillate or with } \\
\text { short, fine rhizines }\end{array}$ \\
\hline Fine rhizines & $0.5-1 \mathrm{~mm}$ long & $0.05-0.1 \mathrm{~mm}$ long \\
\hline Coarse rhizines & solitary, rare & grouped in the center \\
\hline Ascospores & $12-19 \times 6-10 \mu \mathrm{m}$ & $10-12 \times 8-10 \mu \mathrm{m}$ \\
\hline Conidia & $9-14 \times 1 \mu \mathrm{m}$ & $10-14 \times 1 \mu \mathrm{m}$ \\
\hline
\end{tabular}

undersurface, with a marginal and narrow dark brown area. It is related to $P$. erubescens, and some authors thought they were conspecific (Hale 1965; Winnem 1975; Kurokawa 1991). However, P. subcaperatum has the undersurface black in a wide area, usually slightly rugose to veined, the marginal zone being dark brown and the upper surface subfoveolate to foveolate. On the other hand, in P. erubescens, the underside is blackish-brown only in the very center, smooth to papillate, the marginal area very light brown, and the upper surface only scrobiculate. The main characters accepted today for the separation of both species are presented in Table 2 .

Still, some problems remain and could not be here clarified. The holotype of $P$. subcaperatum is corticicolous and coriaceous, with ascospores 14-16 ×9-11 $\mu \mathrm{m}$ and, although with abundant pycnidia, and conidia were not seen. The lectotype of $P$. erubescens is corticicolous, membranaceous, without apothecia, but with conidia $8-11 \times \sim 1 \mu \mathrm{m}$. The features of the underside seem to be comparable to the characters listed by Elix (1997); thus, we are accepting these species as good taxa, at least until more material becomes available for study.

It must be noted that the holotype of $P$. subcaperatum, although full of apothecia, is devoid of several entire lobes, and some features, like lobe margins, cilia, etc., and could not be well evaluated. The rhizines also seem not so clearly dichotomous, probably because of the absence of the lobe apices, where they usually are more common.

The holotype of Parmelia imperforata is well-developed, with ascospores 11-16 $\times 10-12 \mu \mathrm{m}$, episporium $\sim 1 \mu \mathrm{m}$ and conidia $8-10 \times \sim 1 \mu \mathrm{m}$. The underside is paler that $P$. subcaperata, so we are accepting it here as a synonym with a certain reserve since this feature could not be adequately studied in the holotype of $P$. subcaperatum. Chemically, the presence of usnic acid was not detected, the holotype having atranorin (minor), chloroatranorin (trace), salazinic acid (major) and consalazinic acid (minor).

Distribution. North America (Egan et al. 2016), South America and Oceania (Kurokawa 1991). In South America, it is known from Venezuela (Vareschi 1973), Brazil (Zahlbruckner 1930a; Kurokawa 1991; Marcelli 2008), Paraguay (Osorio 1970), Uruguay (Osorio 1972) and Argentina (Calvelo \& Liberatore 2002). In Brazil, it was recorded from Minas Gerais (Kurokawa 1991), Mato Grosso do Sul (Osorio 1992a), Paraná (Osorio 1977b; Kurokawa 1991), Rio de Janeiro (Kurokawa 1991), Rio
Grande do Sul (Spielmann 2005, 2006), Santa Catarina (Gumboski \& Eliasaro 2011) and São Paulo (Kurokawa 1991; Marcelli \& Benatti 2008).

Additional specimens examined. BRAZIL. Minas Gerais: Lagoa Santa, Dr. Warming 313 (M). Rio de Janeiro: 1868, A. Glaziou 2001 (M). BRAZIL. S.d., s.1., Keller (M).

Parmotrema subisidiosum (Müll. Arg.) Hale, Phytologia 28(4): 339. 1974.

(Fig. 51A)

Basionym: Parmelia cetrata var. subisidiosa Müll. Arg., Engler Botanische Jahrbücher 20: 256. 1894.

Type: Africa. Bumba: Usambara, Holst 8772 p.p. (lectotype - G!), according to Hale \& Fletcher (1990).

$\equiv$ Parmelia subisidiosa (Müll. Arg.) Dodge, Annals of the Missouri Botanical Garden 46: 87. 1959.

三 Rimelia subisidiosa (Müll. Arg.) Hale \& Fletcher, The Bryologist 93(1): 29. 1990.

Description (based on lectotype). Thallus brownish, lobate, apparently loosely adnate, corticicolous with mosses, $5.5 \mathrm{~cm}$ broad. Lobes irregularly branched, laterally overlapped, 3-7 mm wide, surface continuous or cracked, smooth or irregularly subscrobiculate, lustrous, becoming strongly cracked and irregular towards the center; apical zone rounded; margin smooth to crenate, undulated. Maculae distinct, reticulate, laminal. Cilia black? simple, short, up to $0.6 \mathrm{~mm}$ long, $0.02-0.05 \mathrm{~mm}$ wide, few. Lacinulae, pustules and soredia absent. Isidia concolor with the thallus, apex usually darker, simple to coralloid, $0.1-0.2 \times 0.05-0.15 \mathrm{~mm}$, erect, firm, or less frequently flaking off, sometimes ciliate, laminal or marginal. Medulla white. Undersurface black, lustrous, smooth or slightly rugose, with few cracks; marginal zone dark brown, pale brown or variegating these colors, lustrous, 1-2 mm wide, naked, with an attenuated limit, smooth or papillate; rhizines black, simple, irregularly branched or squarrose, sometimes with flatted apices, up to $2 \mathrm{~mm}$ long, abundant, evenly distributed.

Apothecia absent. Pycnidia submarginal, inconspicuous, without prominent margin, rare, ostiole black; conidia not found.

Chemistry. Atranorin (minor), chloroatranorin (trace), salazinic acid (major), consalazinic acid (minor). Cortex $\mathrm{K}+$ yellow, $\mathrm{UV}-$; medulla $\mathrm{K}+$ yellow $\rightarrow$ blood red, $\mathrm{C}-$, $\mathrm{KC}-$, $\mathrm{P}+$ strong yellow, $\mathrm{UV}-$. 


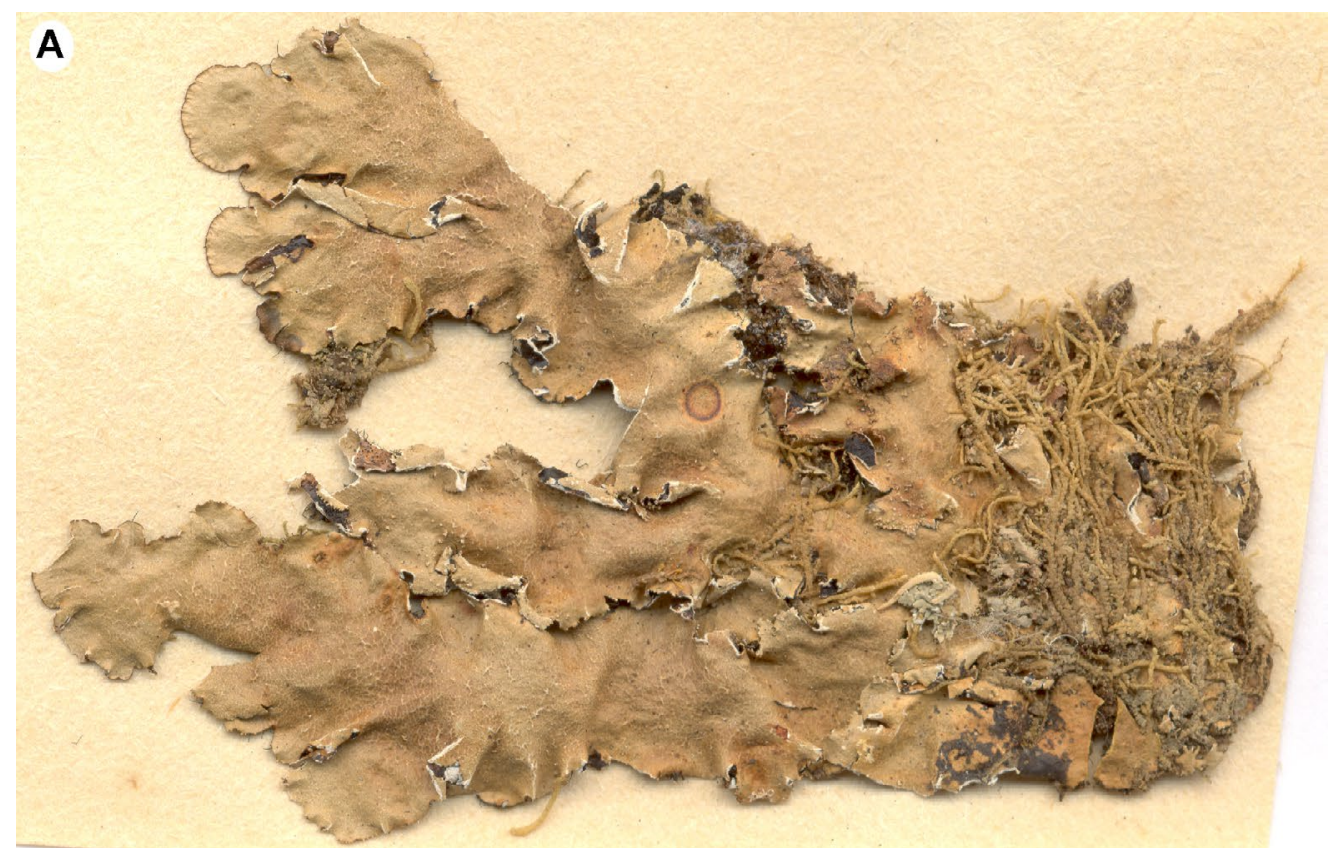

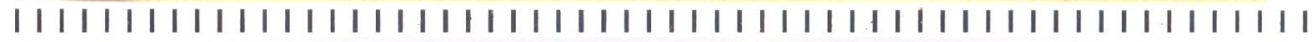

B

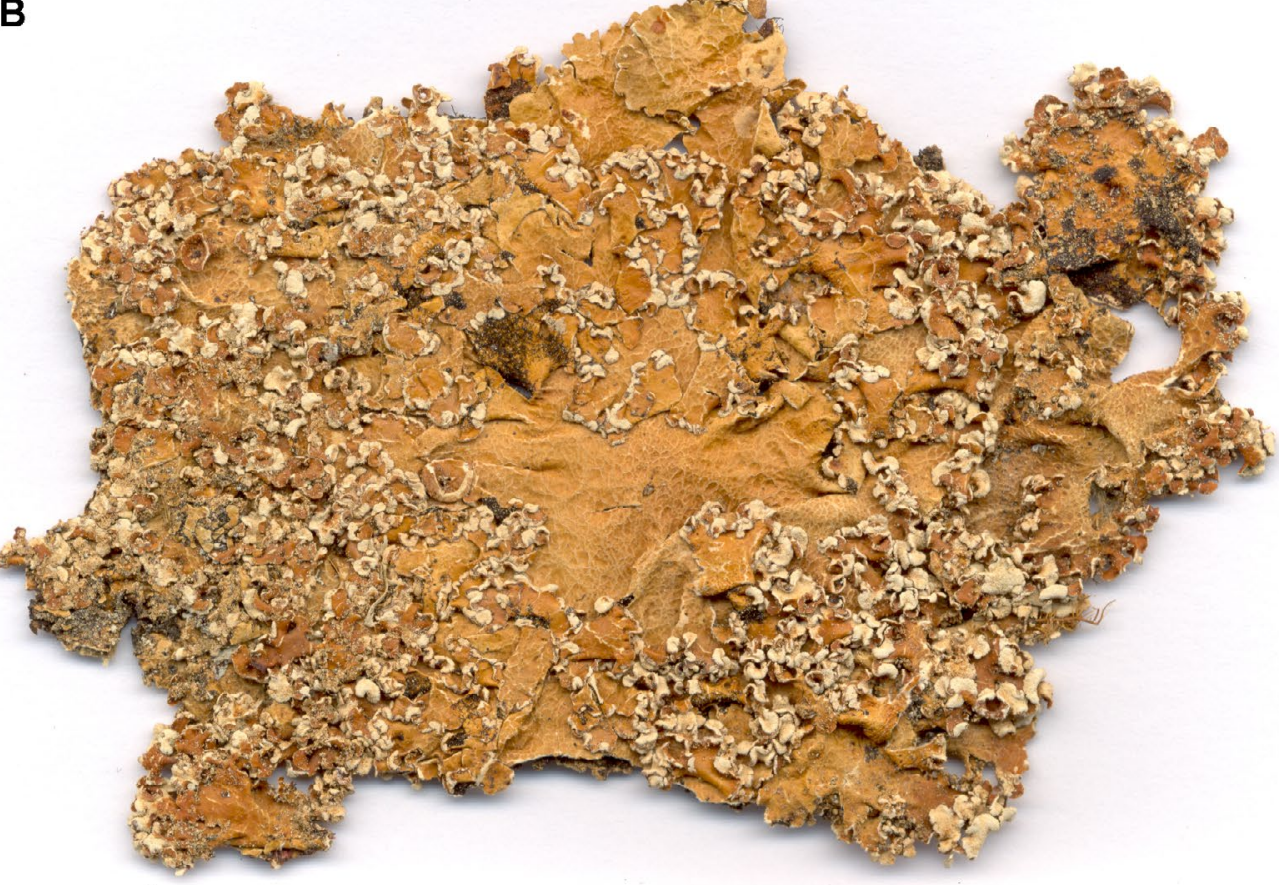

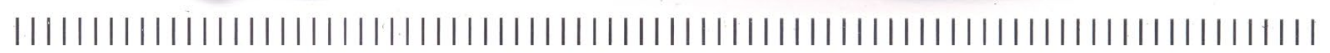

Figure 51. A - holotype of Parmotrema subisidiosum (G); B - holotype of Parmotrema subsumptum (H-NYL). Scales in milimeters.

Remarks. Parmotrema subisidiosum is characterized by the formation of simple to coralloid isidia, the reticulate maculae and the presence of salazinic acid. Parmotrema lacteum, a close species recently described (Marcelli et al. 2007), is distinguished by the formation of capitate sorediose clusters originating isidioid soredia, and the milky thallus (see comments under this species). Another species with reticulate maculae and isidia is $P$. bonplandii, distinct by the chemistry: norlobaridone and lichexanthone instead of salazinic acid (Mata García 1994).

The lectotype of P. subisidiosum is well-preserved, while glued by the underside to a paper. The observations were made using unglued parts. Unfortunately, it does not have apothecia, and conidia were not found in the rare pycnidia seen.

There is a label from $\mathrm{H}$. des Abbayes (dated from 1958) giving the spot tests and providing a new combination, 'Parmelia subisidiosa (Müll. Arg.) des Abb. comb. nov.' . A second label made by Hale in 1959, gives the combination as ' $P$. subisidiosa (Müll. Arg.) Dodge'. Indeed, Dodge (1959) published the new combination and apparently, des Abbayes did not.

Distribution. North America (Moore 1968, Dey 1978, Brodo et al. 2001, Egan et al. 2016), Central America (Tenorio et al. 2002), Tropical America (Hale \& Fletcher 1990) 
and Africa (Dodge 1959; Krog \& Swinscow 1981; Hale \& Fletcher 1990) In South America, it was recorded from Venezuela (Feuerer 2008), Ecuador, Galapagos (Bungartz \& Spielmann 2019), Bolivia (Kukwa et al. 2012), Brazil (Marcelli 2008) and Uruguay (Osorio 1992b). In Brazil, it was reported from Rio Grande do Sul, Santa Catarina (Fleig 1997) and São Paulo (Marcelli 1991; Ribeiro 1998; Benatti \& Marcelli 2008).

Parmotrema subsumptum (Nyl.) Hale, Mycotaxon 5(2): 434. 1977.

(Fig. 51B, 52A)

Basionym: Parmelia subsumpta Nyl., Flora 52: 117. 1869.

Type: Brazil. Minas Gerais: corticicolous, Glaziou s.n., s.d. (holotype - H-NYL n 35451!).

$\equiv$ Rimeliella subsumpta (Nyl.) Kurok., Annals of the Tsukuba Botanical Garden 10: 9. 1991.

三Canomaculina subsumpta (Nyl.) Elix, Mycotaxon 65: 477. 1997. 1880.

= Parmelia urceolata var. nuda Müll. Arg., Flora 63: 266.

Type: Brazil. Rio de Janeiro: prope [Municipality of] Petrópolis, s.d., Deventer 33 (holotype - G!).

= Parmelia virens var. sorediata Müll. Arg., Flora 69: 256 . 1886.

Type: Australia. Queensland: Toowoomba, 1882, Hartmann (holotype-G!).

$\equiv$ Parmelia pseudovirens Gyelnik, Repertorium specierum novarum regni vegetabilis 29: 288. 1931.

$\equiv$ Parmotrema pseudovirens (Gyelnik) Elix, Mycotaxon 47: 127. 1993

= Parmelia hypotropa var. imperialis Hue, Nouvelles Archives du Muséum d'Histoire Naturelle de Paris, ser. 4(1): 189. 1899.

Type: Brazil. Corticicolous, 1887, S. M. Dona Theresa Christina Maria, imperatrix (holotype - P!).

$\equiv$ Parmelia corrugis var. imperialis (Hue) Zahlbr., Catalogus lichenum universalis 6: 236. 1930.

= Parmelia leucoxantha $\mathrm{f}$. firma Sambo, Annali di Botanica 22(1): 18. 1939

Type: Brazil: Rio de Janeiro: Serra dos Órgãos, May 1839 , Casaretto 2444 (holotype - RO!).

Description (based on holotype). Thallus brownish (herbarium), lobate, \pm adnate, corticicolous, $8 \mathrm{~cm}$ broad. Lobes irregularly branched, crowded, usually strongly crisped, 2-10 mm wide, surface usually irregularly cracked, smooth or with irregular depressions, lustrous, becoming reticulately cracked towards the center; apical zone rounded; margin sinuous-incised, usually strongly crisped, sometimes undulated. Maculae weak, effigurate, laminal, originating cracks. Cilia black, simple, up to $1.5 \mathrm{~mm}$ long, 0.02-0.05 mm wide, rare. Lacinulae, pustules, and isidia absent. Soralia white, growing from the margin of the lobes and becoming extensive towards the undersurface, the sorediate lobe margins becoming revolute and strongly crisped; soredia farinose to subgranular. Medulla white. Undersurface dark brown to brown, blackening only in the very center, sublustrous, smooth to papillate or slightly veined, with sparse cracks; marginal zone absent (brown) or pale brown, then $1-5 \mathrm{~mm}$ wide, lustrous, naked or rhizinate, with a sharp limit, smooth to veined or with very slight depressions; rhizines black, dimorphic, the shorter ones simple or sometimes squarrose, usually curled, up to $0.5 \mathrm{~mm}$ long, thin, $0.01-0.04 \mathrm{~mm}$ wide, abundant, evenly distributed; the longer ones up to $3.5 \mathrm{~mm}$ long, thickened, $0.05-0.12 \mathrm{~mm}$ wide, simple or more commonly irregularly branched, especially near the apex, frequent, distributed in groups.

Apothecia cupuliform, 1.3-3.2 mm in diameter, stipitate, laminal, margin smooth to incised, usually involute, sorediate or not, amphithecium maculate, smooth to irregular, disc pale brown to dark brown, epruinose, perforate; ascospores not seen (11-14 × 7-9 $\mu \mathrm{m}$ according to Nylander 1869). Pycnidia submarginal, conspicuous, without prominent margin, few, ostiole black; conidia not found ( $\sim 20$ pycnidia examined). See comments below under Parmelia urceolata var. nuda.

Chemistry. Atranorin (minor), chloroatranorin (trace), salazinic acid (major), consalazinic acid (minor). Cortex $\mathrm{K}+$ yellow, UV-; medulla $\mathrm{K}+$ yellow $\rightarrow$ blood red, $\mathrm{C}-$, $\mathrm{KC}-, \mathrm{P}+$ strong yellow, $\mathrm{UV}-$.

Remarks. Parmotrema subsumptum is characterized by the strongly crisped lobes sorediate at the undersurface, the effigurate (although weak) maculae, the dichotomous rhizines and the simple and rare cilia. The ontogeny of the soralia is quite interesting since they start at the margin and extend backwards on the undersurface, not the upper surface as is common in Parmotrema. In Parmotrema petropoliense, before thought to be a synonym (Hale 1965), the soralia are formed in the margin or on the upper surface of conspicuous lacinulae that form pustuloid structures (i.e., not extensive). Additionally, it has abundant, long (up to $3 \mathrm{~mm}$ ) and usually furcated cilia. Parmotrema leucosemothetum can be distinguished by the soralia almost exclusively marginal, the strongly maculate upper cortex (with effigurate maculae), the simple, usually thickened and \pm tapering cilia, and the distinctly shiny bare marginal zone on the undersurface. Finally, Parmotrema margaritatum has the soralia growing subapically in lacinulae, the upper surface hypermaculate, and a black undersurface with monomorphic rhizines.

The holotype of Parmotrema subsumptum seems to have been pressed, as can be seen by the strongly flattened lobes. It has three poorly developed apothecia, and one tentative search for ascospores was made in the largest one. However, the hymenium was immature, and no ascospores were found. Thus, we have to trust the measurements given by Nylander. Nevertheless, he published (Nylander 1869) ascospores with 11-14 × 7-9 $\mu \mathrm{m}$, although his handwriting on the envelope states ' $14-16 \times$ $7-9 \mu \mathrm{m}$ '. Hale (1965) found ascospores $12-15 \times 7-10 \mu \mathrm{m}$.

The holotype of Parmelia urceolata var. nuda agrees well with Parmotrema subsumptum. It is completely eciliate, and the ontogeny of the soralia described for P. subsumptum is more evident here. Conidia were found, and they are filiform, 7.5-12 $\times \sim 1 \mu \mathrm{m}$. The information concerning the collector (Deventer 33) could not be confirmed since there is no label about this. Thus, that datum comes from Hale (1965). 

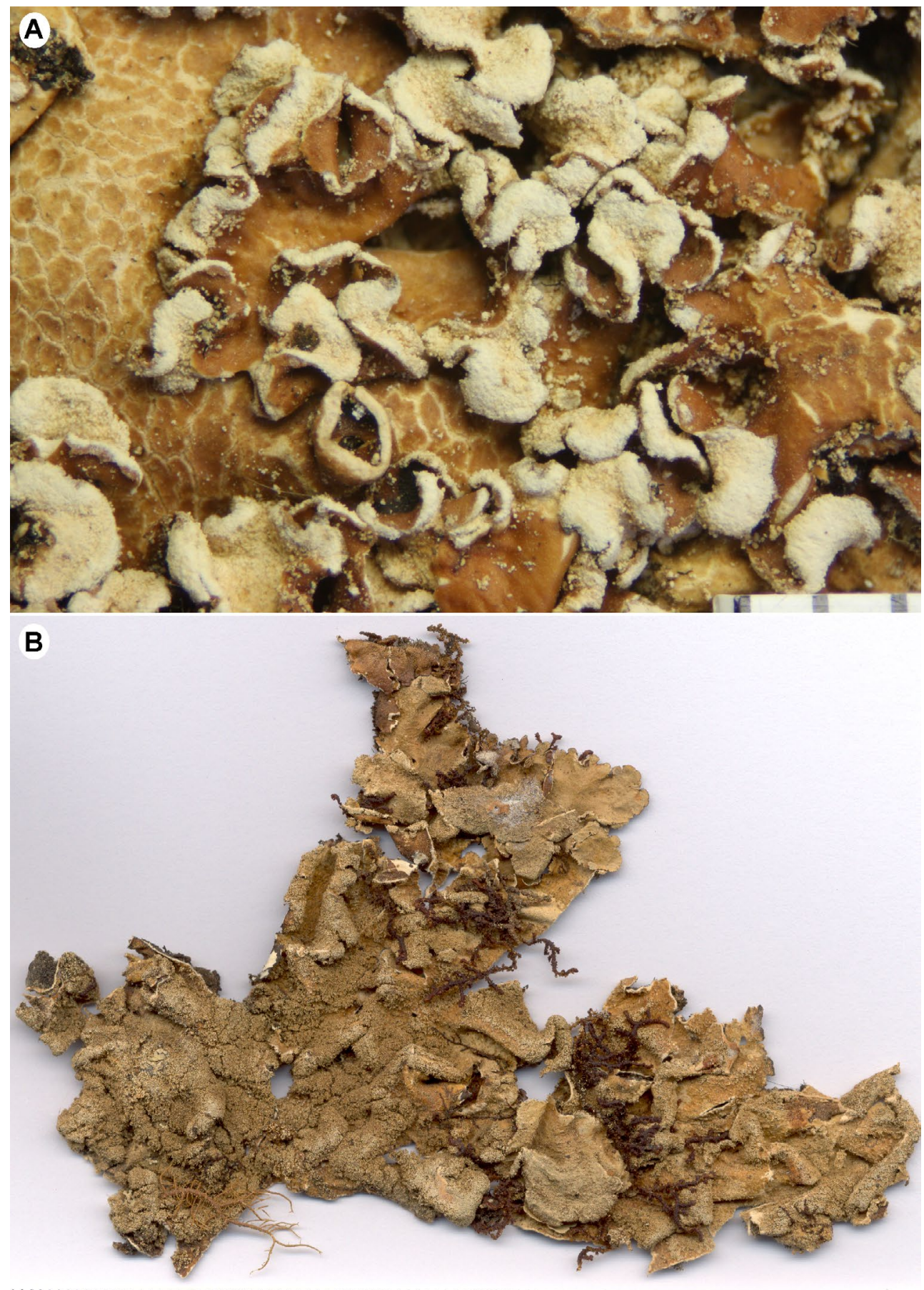

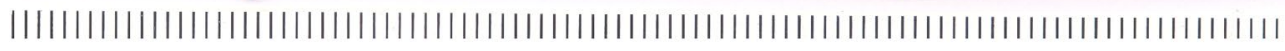

Figure 52. A - holotype of Parmotrema subsumptum (H-NYL), showing the sorediate lobes; B - holotype of Parmotrema subtinctorium (WU). Scales in milimeters.

The holotype of Parmelia hypotropa var. imperialis Hue consists of three thalli, all of them agreeing with Parmotrema subsumptum in the overall morphology, being scarcely ciliate. One thallus has several well-developed apothecia, up to $6 \mathrm{~mm}$ in diameter, laminal, substipitate to stipitate, usually strongly maculate and longitudinally rugose, disc perforate, the margin irregularly sorediate, the ascospores (most immature) being 14-16.5 $\times 7-9 \mu \mathrm{m}$. It has the undersurface extensively dark brown and black in some areas while in the larger thallus $(13 \mathrm{~cm}$ broad, lobes $5-18 \mathrm{~mm}$ wide) is entirely brown. Few pycnidia are present in this thallus, but no conidia were found
( $\sim 20$ pycnidia examined). The third thallus seems to be part of the fertile thallus. Hue's (1899) description is a combination of the features from the three thalli. The two smallest thalli are undoubtedly P. subsumptum. The largest thallus is perhaps a different species.

The holotype of Parmelia leucoxantha f. firma is also identical with the holotype of $P$. subsumptum, only the undersurface was not studied in detail since the thallus is strongly attached to bark. The chemical study revealed the presence of protolichesterinic acid (minor), besides atranorin (minor), chloroatranorin (trace), salazinic acid (major) and consalazinic acid (minor); therefore, 
additional collections are necessary to determine whether protolichesterinic acid is an accessory substance.

The holotype of Parmelia virens var. sorediata presented the same chemical profile as P. subsumptum and also shares the typical crisped sorediate lobes, effigurate maculae and dimorphic rhizines. Gyelnik (1931b) was the first to propose a new name for this lichen (Parmelia pseudovirens) and was later followed by Elix (1993), who combined it in Parmotrema. However, soon Elix (1994) placed it as a synonym of Rimelia reticulata.

Distribution. Americas (Hale 1965; Kurokawa 1991; Egan et al. 2016), Africa (Hale 1965; Winnem 1975; Krog \& Swinscow 1981), Asia (Kurokawa 1991; Kurokawa \& Lai 2001; Chen et al. 2003; Divakar \& Upreti 2005) and Oceania (Kurokawa 1991; Elix 1994; Louwhoff \& Elix 1999). In South America, it is known from Venezuela (Dodge 1957, as Parmelia hypotropa var. imperialis; Hale 1965), Bolivia (Kukwa et al. 2012), Brazil (Hue 1899), Uruguay (Osorio 1979; Kurokawa 1991) and Argentina (Hale 1965; Kurokawa 1991). In Brazil, it was reported from Minas Gerais (Nylander 1869; Hale 1965; Kurokawa 1991; Ribeiro 1998), Paraná (Eliasaro 2001), Rio de Janeiro (Müller Argoviensis 1880; Cengia Sambo 1939c; Kurokawa 1991), Rio Grande do Sul (Spielmann 2006) and São Paulo (Hale 1965; Ribeiro 1998).

Parmotrema subtinctorium (Zahlbr.) Hale, Phytologia 28(4): 339. 1974.

(Fig. 52B)

Basionym: Parmelia subtinctoria Zahlbr., in Handel-Mazetti, H.: Symbolae sinicae. Botanische Ergebnisse der Expedition der Akademie der Wissenschaften in Wien nach Südwest-China 1914/1918, III, Lichenes. J. Springer, Wien, p. 193.

Type: China, Yünnan: prope vicum Sanyingpan ad septentr. urbis Yünnanfu, $26^{\circ}$ lat., in regione calide temperata, substr. córtice Quercuum, alt. s.m. 2.400 m alt., 14.III.1914, Dr. Heinr. Frh. v. Handel-Mazzetti 5645 (Diar. Nr. 146) (holotype - WU!).

$\equiv$ Rimeliella subtinctoria (Zahlbr.) Kurok., Annals of the Tsukuba Botanical Garden 10: 10. 1991.

三 Canomaculina subtinctoria (Zahlbr.) Elix, Mycotaxon 65: 477. 1997.

= Parmelia virens f. isidiosa Müll. Arg., Annalen des K. K. naturhistorischen Hofmuseums 7: 303. 1892.

Type: Australia. Queensland: near Toowoomba, Hartmann 58 (holotype - W!; isotype - G!).

$=$ Parmelia leucosemotheta $\mathrm{f}$. isidiata Hue, Nouvelles Archives du Muséum d'Histoire Naturelle de Paris, sér. 4(1): 192. 1899. $-\mathrm{PC} !)$.

Type: USA Ohio: corticicolous, Lesquereux 262 (holotype

Description (based on holotype). Thallus brownish (herbarium), lobate, loosely adnate, corticicolous, $10 \mathrm{~cm}$ broad. Lobes irregularly branched, laterally overlapped to crowded, usually strongly curled, 4-12 mm wide, surface slightly scrobiculate, becoming strongly cracked in the center; apical zone and margins usually curled down, when visible the apical zone is rounded, and the margin crenate to incised, plane. Maculae distinct, effigurate, laminal. Cilia black, simple, up to $1 \mathrm{~mm}$ long, $0.02-0.05 \mathrm{~mm}$ wide, few and usually broke. Lacinulae, pustules and soredia absent. Isidia concolor with the thallus or a little paler, apex dark brown, simple to coralloid, $0.1-1 \times$
0.05-0.2 mm, erect, firm, apex eciliate, laminal. Medulla white. Undersurface dark brown to black in the central zone, lustrous, slightly rugose or papillate, with scars; marginal zone brown to pale brown, lustrous, $2-5 \mathrm{~mm}$ wide, naked or with initial rhizines, with an attenuated limit, difficult to distinguish, slightly rugose and papillate, except in some areas where remains smooth; rhizines black or dark brown, abundant, dimorphic, the smaller ones simple and usually curled, up to $0.5 \times 0.05 \mathrm{~mm}$, more or less evenly distributed, the larger ones simple to sometimes branched, up to $3 \times 0.2 \mathrm{~mm}$, distributed in groups.

Apothecia (from the holotype of Parmelia leucosemotheta $\mathrm{f}$. isidiata) cupuliform, 1.2-4 $\mathrm{mm}$ in diameter, substipitate, margin isidiate, amphithecium isidiate, disc brown, epruinose, imperforate; ascospores not found (8-11 × 5-8 $\mu \mathrm{m}$ according to Hale 1965). Pycnidia submarginal, conspicuous, without prominent margin, few, ostiole black; conidia filiform, 9-15 $\times \sim 1 \mu \mathrm{m}$.

Chemistry. Atranorin (minor), chloroatranorin (trace), salazinic acid (major), consalazinic acid (minor), norlobaridone (minor), loxodin (trace), protocetraric acid (trace). Cortex $\mathrm{K}+$ yellow, UV-; medulla $\mathrm{K}+$ yellow $\rightarrow$ blood red, $\mathrm{C}-, \mathrm{KC}-, \mathrm{P}+$ strong yellow, UV-.

Remarks. Parmotrema subtinctorium is distinguished by the isidiate thallus with effigurate maculae, the undersurface slightly rugose to papillate, the absence of usnic acid and the presence of norlobaridone. It is morphologically close to $P$. neotropicum, which isidia can become sorediate, the underside is abundantly veined and additionally has usnic acid and lacks norlobaridone. Kurokawa (1991) reduced Parmotrema haitiense to the synonymy of $P$. subtinctorium. That species was not studied here since it lacks salazinic acid, but we agree with Elix (1993) and Fleig (1997) that they are distinct species.

The typification of Parmelia virens f. isidiosa requires some comments. Hale (1965) reported the specimen from $\mathrm{G}$ as 'holotype', as also in a label dated 1963. However, on that same label, he added 'indeterminable scraps'. That is because there are two pieces of two different lichens in the envelope: one of them is Parmotrema subtinctorium, and the other Parmelia virens (= Parmotrema reparatum). Observing more closely the specimen in $\mathrm{W}$, it also presents the same two species, but well-developed. Obviously, the 'scraps' preserved in G were taken from the $\mathrm{W}$ collection; thus, we are proposing that the holotype is present in $\mathrm{W}$ and the isotype in $\mathrm{G}$. Additionally, the chemistry of the $\mathrm{W}$ specimen is almost identical with the holotype of $P$. subtinctorium, the only exception being the absence of traces of protocetraric acid in the $\mathrm{W}$ specimen. Traces of protocetraric acid were found in the specimen of $\mathrm{G}$, but not norlobaridone and loxodin. Maybe this can be due to the very small fragment sent for chemical analysis since the specimens are obviously the same. The morphology of the W specimen matches the holotype of $P$. subtinctorium, with the dimorphic rhizines, effigurate maculae (quite indistinct at first glance) and very rare cilia. 

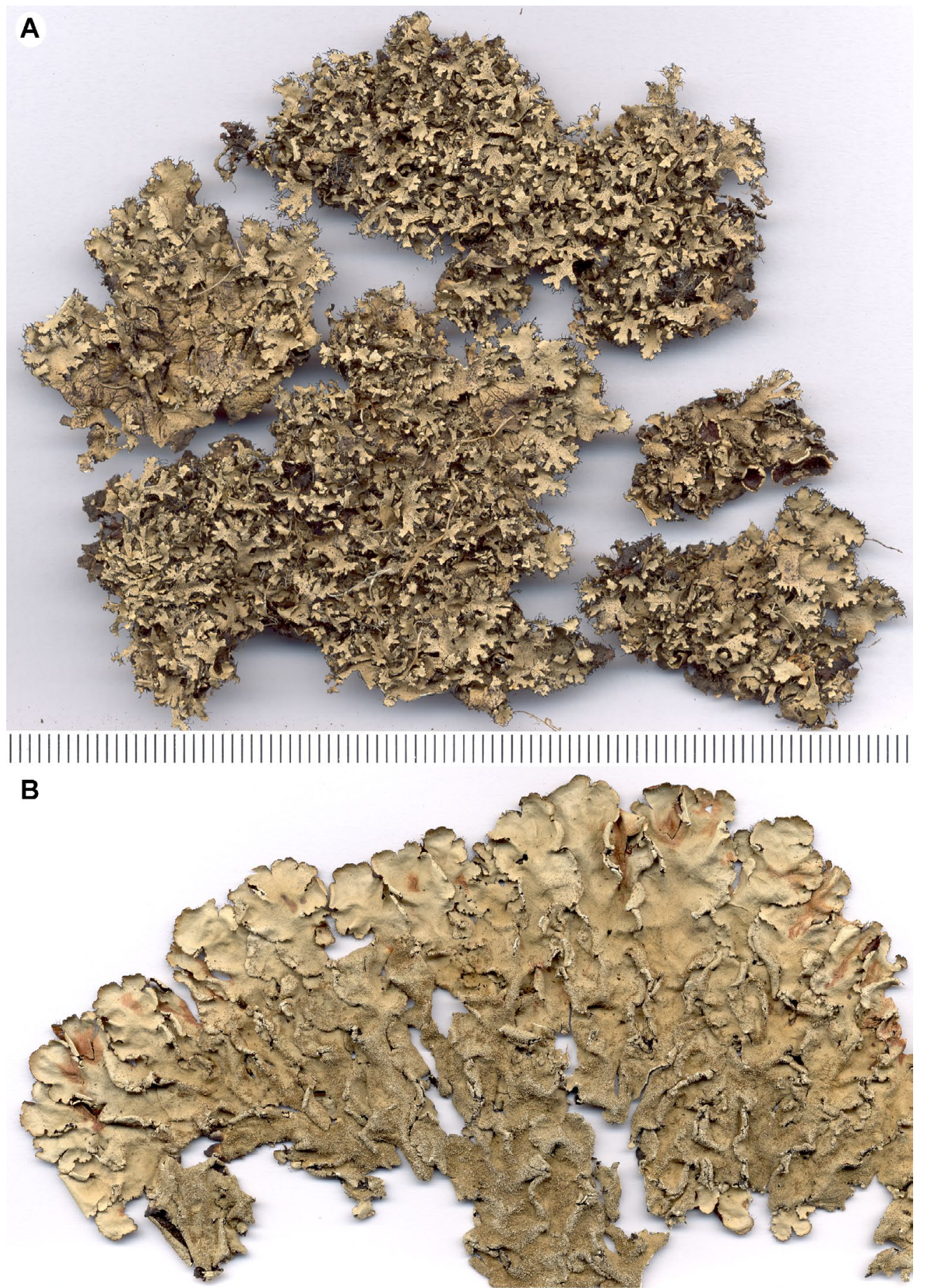

|| || || || || || || |||||||||||||||||||||||||||||||||||||||||||||||||||||||||||||||||||||||||||||||||||||||||||||||||||||||||||||||||||||||||||||||||||||||||||||

Figure 53. A - holotype of Parmotrema tandilense (BAFC); B - holotype of Parmotrema ultralucens (O). Scales in milimeters.

Since the conidia were not found in the holotype of Parmotrema subtinctorium ( $\sim 30$ pycnidia examined), we used the conidial data from the holotype of the synonym Parmelia leucosemotheta f. isidiata Hue, as well as the apothecium features. This type agrees well with the chemical and morphological features found in the holotype of P. subtinctorium, except for the absence of traces of protocetraric acid.

Hale (1965) reported several synonyms to $P$. subtinctorium, but two of them were still not investigated: Parmelia velutina Zahlbr. [non Parmelia velutina (Ach.) Wallr.], and Parmelia protovirens Gyelnik.
See also comments under Parmotrema ultralucens, especially regarding the neotype of Parmelia subcrinita.

Distribution. Americas (Hale 1965; Egan et al. 2016), Africa (Hale 1965; Winnem 1975; Krog \& Swinscow 1981) and Asia (Hale 1965; Park 1990; Kurokawa 1991; Kurokawa \& Lai 2001; Chen et al. 2003; Divakar \& Upreti 2005). In South America, it is known from Brazil (Ribeiro 1998; Donha 2005) and Paraguay (Hale 1965). In Brazil, it was recorded from Minas Gerais (Ribeiro 1998), Pernambuco (Buril 2015) and Paraná (Donha 2005). 
Parmotrema tandilense (Adler \& Elix) Blanco, Crespo, Divakar, Elix \& Lumbsch, Mycologia 97(1): 158. 2005.

(Fig. 53A)

Basionym: Canomaculina tandilensis Adler \& Elix, Mycotaxon 30: 339. 1987.

Type: Argentina. Buenos Aires: Tandil, Partido de Tandil, $37^{\circ} 20^{\prime} \mathrm{S}, 59^{\circ} 09^{\prime} \mathrm{W}, 350 \mathrm{~m}$ elev., on granite rock, on Hill above 'La Cascada', I.1987, M.T. Adler (holotype - BAFC 35.901!, isotypes - CANB!, US!).

Remarks. This species is very close to Parmotrema ventanicum, as already asserted by the original authors (Adler \& Elix 1987). The hypermaculate thallus is also very evident. Adler and Elix (1987) interpreted this type of maculae as effigurate. Parmotrema tandilense resembles $P$. herrei. Lacinulae can be indicative of some species group.

Distribution. Argentina and Uruguay (Adler \& Elix 1987).
Parmotrema ultralucens (Krog) Hale, Mycotaxon 1(2): 108. 1974.

(Fig. 53B)

Basionym: Parmelia ultralucens Krog, The Bryologist 77(2): 253. 1974.

Type: USA Georgia: Harris Co., Dowdell's Knob, on rock, 1965, H. Krog (holotype - O!; isotypes - BM!, S and US).

三 Canomaculina ultralucens (Krog) Elix \& J.B. Chen, Mycotaxon 86: 21. 2003.

= Parmelia monumentalis Asahina (not validly published, according to Krog 1974, p. 256).

Description (based on holotype). Thallus pale brownish (herbarium), lobate, loosely adnate, saxicolous, $18 \mathrm{~cm}$ broad. Lobes irregularly branched, laterally overlapped, 3-11 mm wide, surface continuous, smooth to irregular, lustrous, sometimes pruinose in the apices, becoming rugose toward the center; apical zone rounded; margin crenate, undulated. Maculae weak and inconspicuous, although covering most of the surface, punctiform to
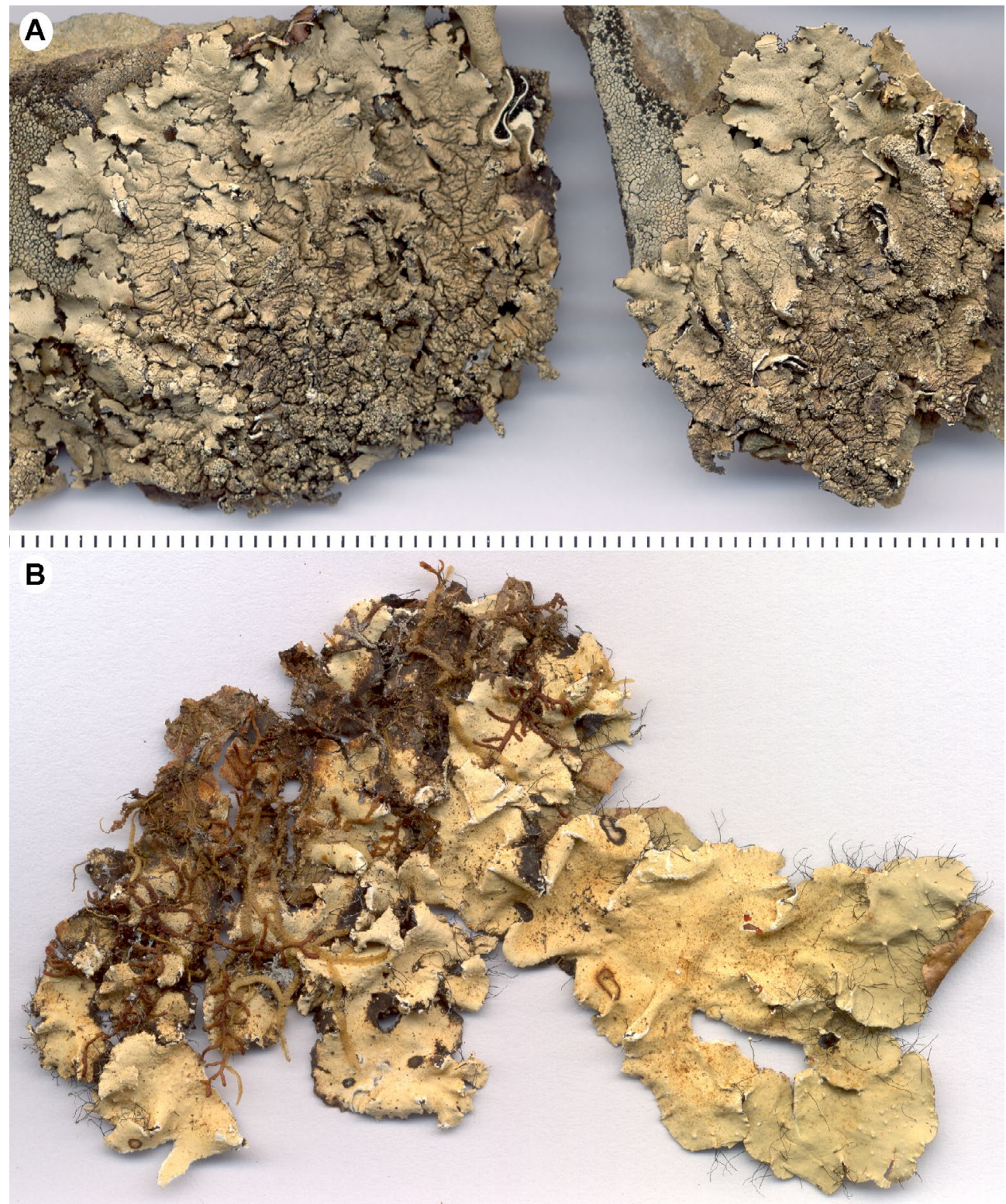

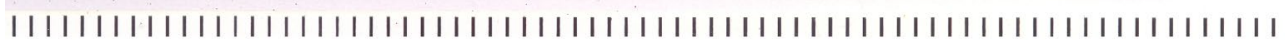

Figure 54. A - holotype of Parmotrema ventanicum (UPCB); B - holotype of Parmotrema verrucisetosum (B). Scales in milimeters. 
effigurate, usually forming a pseudoreticulate pattern. Cilia black, simple or cespitose, $0.5-1(-1.3) \times 0.02-$ $0.05 \mathrm{~mm}$, abundant. Isidia paler or darker than the cortex, apex strongly dark brown, simple to less frequently branched, sometimes coralloid, up to $0.5 \times 0.05-0.1 \mathrm{~mm}$, erect, firm, apex sometimes ciliate laterally, laminal and marginal. Lacinulae, soralia, and pustules absent. Medulla white. Undersurface black, lustrous, smooth to papillate or slightly rugose, with cracks; marginal zone dark brown, lustrous, 1.5-4 mm wide, naked, with an attenuated limit, smooth to slightly rugose; rhizines black, simple or rarely branched, up to $1.5 \mathrm{~mm} \times 0.01-0.1 \mathrm{~mm}$, abundant, evenly distributed.

Apothecia absent (according to Krog 1974, apothecia rare, up to $8 \mathrm{~mm}$ in diameter, disc imperforate, ascospores 15-17 × 10-12 $\mu \mathrm{m})$. Pycnidia submarginal, conspicuous, with or without prominent margin, few, ostiole black; conidia short filiform, $6-10 \times \sim 1 \mu \mathrm{m}$.

Chemistry. Atranorin (minor), chloroatranorin (trace), salazinic acid (major), consalazinic acid (minor), lichexanthone (minor). Cortex $\mathrm{K}+$ yellow, $\mathrm{UV}-$; medulla $\mathrm{K}+$ yellow $\rightarrow$ orange red, $\mathrm{C}-, \mathrm{KC}-, \mathrm{P}+$ strong yellow, $\mathrm{UV}+$ yellow.

Remarks. Parmotrema ultralucens is characterized by the isidiate thallus, the cespitose cilia and the presence of both lichexanthone and salazinic acid in the medulla. When describing the species, Krog (1974) asserted that it rarely has apothecia, and she does not indicate to what specimen the apothecia examined belong. However, we did not find apothecia at all in the holotype. The isotype from BM agrees well with the holotype, but it also lacks developed apothecia. Krog (1974) also reported that Hale (1965) selected as neotype of Parmelia subcrinita, he specimen H-NYL 35472; however, the specimen listed by Hale is H-NYL 35479, likely a lapsus.

The name Parmelia subcrinita was rejected by Krog (1974), according to the Article 69 of the Seattle Code (Stafleu et al. 1972). Krog argues that the neotype may not fit the original concept of $P$. subcrinita, so this is a matter of proper typification. With the current neotype, $P$. subcrinita would be an earlier name for Parmotrema subtinctorium.

Distribution. North America (Hale 1965; Esslinger 2008; Egan et al. 2016), Central America (Hale 1965), South America (Hale 1965; Krog 1974), Africa (Krog 1974; Swinscow \& Krog 1988), Asia (Hale 1965; Krog 1974; Kurokawa \& Lai 2001; Elix et al. 2002; Chen et al. 2003), Azores (Hale 1965; Krog 1974) and Oceania (Hale 1965; Krog 1974; Elix 1994; Louwhoff \& Elix 1999). In South America, it was recorded from Colombia (Hale 1965), Ecuador (Hale 1965), Ecuador, Galápagos (Bungartz \& Spielmann 2019) and Brazil (Hale 1965). In Brazil, it was cited for Minas Gerais (Hale 1965), Rio Grande do Sul (Spielmann 2006), Santa Catarina (Marcelli 1992) and São Paulo (Marcelli 1992; Benatti 2005).

Additional specimens examined. VENEZUELA. Lara: Sierra Portuguesa, en Villa Nuevita, vía Guarico - Villa Nueva, remains of primitive forests, $1300 \mathrm{~m}$, corticicolous, 30 March 1979, M. López Figueiras \& M. E. Hale 19776 (US). Mérida: La Solada along Via Azulita, 900 m, rocky open pasture, 3 February 1974, M.E. Hale 42749 (US). Táchira: Vía La Grita, Páramo del Rosal, 1440-1850 m, 30 March 1975, M.E. Hale \& M. López Figueiras 45681 (US). Táchira: Vía Villa Paez-Betania, valley of Páramo de Tama, open rocky pastures, 2000-2300 m, 25 March 1975, M.E. Hale \& M. López Figueiras 45086 (US). BRAZIL. São Paulo: Municipality of Itanhaém, Near bridge over Itanhaém River, Km 112 of BR-101 highway (Rodovia Padre Manoel da Nóbrega), on mangrove trees, July 1979, M.P. Marcelli 9 (US). Idem, Bertioga, Guaratuba beach, on mangrove trees near Guaratuba river, January 1982, M.P. Marcelli 40, 51, $52,53,55,56$ (US).

Parmotrema ventanicum (Adler \& Elix) Blanco, Crespo, Divakar, Elix \& Lumbsch, Mycologia 97(1): 158. 2005.

(Figs 4A,54)

Basionym: Canomaculina ventanica Adler \& Elix, Mycotaxon 30: 340. 1987.

Type: Argentina. Buenos Aires: Partido de Tornquist, Sierra de La Ventana, Arroyo Los Helechos, margen isquierda, frente Hotel Casino, $38^{\circ} 08^{\prime} \mathrm{S}, 61^{\circ} 53^{\prime} \mathrm{W}, 250 \mathrm{~m}$ elev., on rocks, V.1986, M.T. Adler (holotype - BAFC 35.762!; isotype - CANB!).

Description (based on holotype). Thallus milky brown (herbarium), sublaciniate, adnate, saxicolous, $\sim 10 \mathrm{~cm}$ broad. Lobes irregularly branched, laterally overlapped to somewhat crowded in some central areas, 2-7 mm wide, surface continuous to cracked, smooth to irregular, sublustrous, becoming strongly transversally cracked towards the center; apical zone subtruncate to almost rounded; margin incised, sublacinulate, subplane to undulated. Maculae extensive (hypermaculate), laminal, delimiting irregular dots. Cilia black, simple or rarely furcated, robust and tapering, usually curved downwards, up to $0.8 \mathrm{~mm}$ long, 0.05-0.1 mm wide, abundant. Pustules capitate or irregular, submarginal, originating soredia. Soredia granular. Lacinulae and isidia absent. Medulla white. Undersurface [difficult to observe since the parts of the holotype are closely attached to the rock] black, lustrous, smooth to slightly rugulose, without cracks; marginal zone blackish brown to brown or rarely pale brown, lustrous, up to $2 \mathrm{~mm}$ wide, naked or rhizinate, with attenuated limit, smooth to papillate; rhizines black, simple or rarely branched near the apices, up to $2 \mathrm{~mm}$ long, 0.02-0.2 $\mathrm{mm}$ wide, abundant, evenly distributed.

Apothecia and pycnidia unknown.

Chemistry. Atranorin, chloroatranorin, salazinic acid (major), virensic acid (major), protocetraric acid (minor) and consalazinic acid (minor) (Adler \& Elix 1987). Cortex $\mathrm{K}+$ yellow, UV-; medulla $\mathrm{K}+$ yellow $\rightarrow$ blood red, $\mathrm{C}-$, $\mathrm{KC}-, \mathrm{P}+$ strong yellow, $\mathrm{UV}-$.

Remarks. Parmotrema ventanicum is recognized by the combination of a hypermaculate thallus with robust, tapering cilia, the production of pustules and the presence of virensic acid in addition to salazinic acid and protocetraric acid. It is very close to $P$. tandilense, the main differences being the presence of pustules in $P$. ventanicum, and the presence of abundant lacinulae in $P$. tandilense. These 
taxa should be subjected to molecular studies since they are similar and could constitute actually only one species. Nevertheless, the present species concept in parmotremoid lichens supports the separation. Additionally, apothecia and conidia are unknown in $P$. ventanicum, preventing further comparisons. Other similar species are Parmotrema elixii and $P$. granulare. Both have pustules, but can be easily distinguished by the reticulate maculae, the thinner, not robust cilia, and the absence of virensic and protocetraric acids. P. granulare has abundant lacinulae, the pustules being restricted to them, while $P$. elixii does not develop lacinulae and the pustules usually form dense agglomerations.

The hypermaculate thalli in $P$. ventanicum and $P$. tandilense are very conspicuous since the maculae clearly delimit the irregular spaces without maculae. This feature is more salient on the lobe apices. This type of maculation can set both $P$. ventanicum and $P$. tandilense close to the species of the former genus Concamerella. Based on the descriptions provided by Culberson \& Culberson (1981) and Adler \& Elix (1987), the anatomy can be very similar, the algae being confined to 'algal chambers'.

The holotype is well preserved, constituted by some parts of a presumably one or few thalli, each adnate to a piece of rock. The isotype in CANB agrees in all respects with the holotype.

\section{Distribution. Argentina (Adler \& Elix 1987).}

Parmotrema verrucisetosum Sipman, Mycotaxon 44(1): 8. 1992.

(Figs 54B, 55A)

Type: Guyana. Upper Mazaruni: trail from Kamarang river to Pwipwi mountain, $\mathrm{N}$ of Waramadan, rocky savannah, c. $10 \mathrm{Km}$ $\mathrm{N}$ of Waramadan, $05^{\circ} 57^{\prime} \mathrm{N}, 60^{\circ} 45^{\prime} \mathrm{W}, \sim 800 \mathrm{~m}$ alt., 28 February 1985, H. Sipman \& A. Aptroot 19478 (holotype - B!).

Description (based on holotype). Thallus greenish-gray to whitish-straw towards the center, lobate, loosely adnate, corticicolous, 3-7.3(-10) cm broad. Lobes irregularly branched, laterally overlapped, 2-11 mm wide, surface continuous, smooth, reticulately cracked towards the center, opaque or slightly lustrous in some areas; apical zone rounded; margin crenate, plane or undulate. Lacinulae absent. Maculae absent. Cilia black, simple, furcated, dichotomous or sometimes cespitose, 0.5-3.5 $\times$ $\sim 0.05 \mathrm{~mm}$, abundant, present in the margin and on the laminal and marginal warts. Pustules, soredia and isidia absent. Warts conical or flatted, 0-2 × 1-4 mm, laminal and marginal, often with one or more cilia. Medulla white, slightly orange in some areas, probably due to the decomposition of the salazinic acid. Undersurface black, lustrous, often smooth and with many cracks, sometimes rugose or papillate, rarely scrobiculate; margin absent, beige or eburneous, lustrous, 1-4 mm wide, naked, limit to attenuate to sharp, smooth, sometimes slightly rugose or with barely distinct depressions; rhizines black, cylindrical or rarely flattened in the basal portion, simple, $0.5-3 \times$ 0.05-0.2 mm, frequent, distributed in groups.

Apothecia and pycnidia unknown.
Chemistry (TLC in solvent A and B). Atranorin and salazinic acid (Sipman \& van Aubel 1992). Cortex K+ yellow, UV-; medulla $\mathrm{K}+$ yellow $\rightarrow$ blood red, $\mathrm{C}-$, $\mathrm{KC}-$, $\mathrm{P}+$ strong yellow, UV-.

Remarks. Parmotrema verrucisetosum is characterized by the presence (often) of ciliate warts, which distinguish it from all other known Parmotrema. The cilia, on sight, seem to have numerous lateral branches (bristles). With more attention, however, one can perceive the bristles are just fungi growing on the cilia, sometimes reaching the thallus surface. Actually, these are anamorphic hyphomycetous fungi (R.A.P Grandi, pers. comm.). The under cortex presents several cracks, a feature already observed in several other parmotremoid lichens with salazinic acid. Sipman \& van Aubel (1992) described this in the protologue.

When comparing the holotype with the protologue, the first item, thallus size, is a little problematic. The holotype is composed of several pieces, one of them well-developed. There is no indication if all were part of the same thallus, and even connecting the parts, the total size does not reach $10 \mathrm{~cm}$. In the protologue, the size is reported as 'up to at least $12 \mathrm{~cm}$ '. That left us to compare the holotype with the picture in the protologue, in which the lichens seem to be entire. And they really are. However, it is not the picture of the holotype (Sipman \& Aptroot 19478), but an additional specimen studied (Sipman 26595, B, VEN), from Venezuela, not Guyana, collected in 1990. The warts detail is also from this specimen.

Distribution. Venezuela, Guyana (Sipman \& van Aubel 1992).

Parmotrema warmingii (Vain.) Spielmann \& Marcelli, comb. nov.

(Fig. 55B)

\section{MycoBank MB 838196}

Basionym: Parmelia warmingii Vain., Acta Societatis pro Fauna et Flora Fennica 7(1): 41. 1890.

Type: based on Parmelia angustata Kremp. non Pers.

$\equiv$ Parmelia angustata Kremp., Videnskabelige meddelelser fra den Naturhistoriske forening i Kjöbenhavn 5: 13, 1873. Not Parmelia angustata Pers. in Gaudichaud-Beaupré, Voyage autour du monde, exécuté sur les corvettes l'Uranie et la Physcienne, sur les ordres du Cap. L. de Freycinet, en 1817-1820, Botanique, p. 195, 1826 [三 Pannoparmelia angustata (Pers.) Zahlbr., according to Galloway (2007)].

Type: Brazil. Minas Gerais: [Municipality of Caeté], Serra da Piedade, Dr. Warming 324 (lectotype - M!; isolectotypes - C!, W!).

Description (based on lectotype). Thallus dirty beige to blackened (herbarium), laciniate, loosely adnate, saxicolous, $4 \mathrm{~cm}$ broad. Laciniae dichotomous, crowded, $0.5-2 \mathrm{~mm}$ wide, surface continuous to irregularly scared, smooth, lustrous, becoming irregularly or reticulately cracked towards the center; apical zone usually acute, sometimes truncate; margin smooth, with a conspicuous black line, plane to slightly undulated. Maculae extensive (hypermaculate), laminal, not originating cracks. Cilia black, simple, up to $2.3 \mathrm{~mm}$ long, $0.01-0.05 \mathrm{~mm}$ wide, 

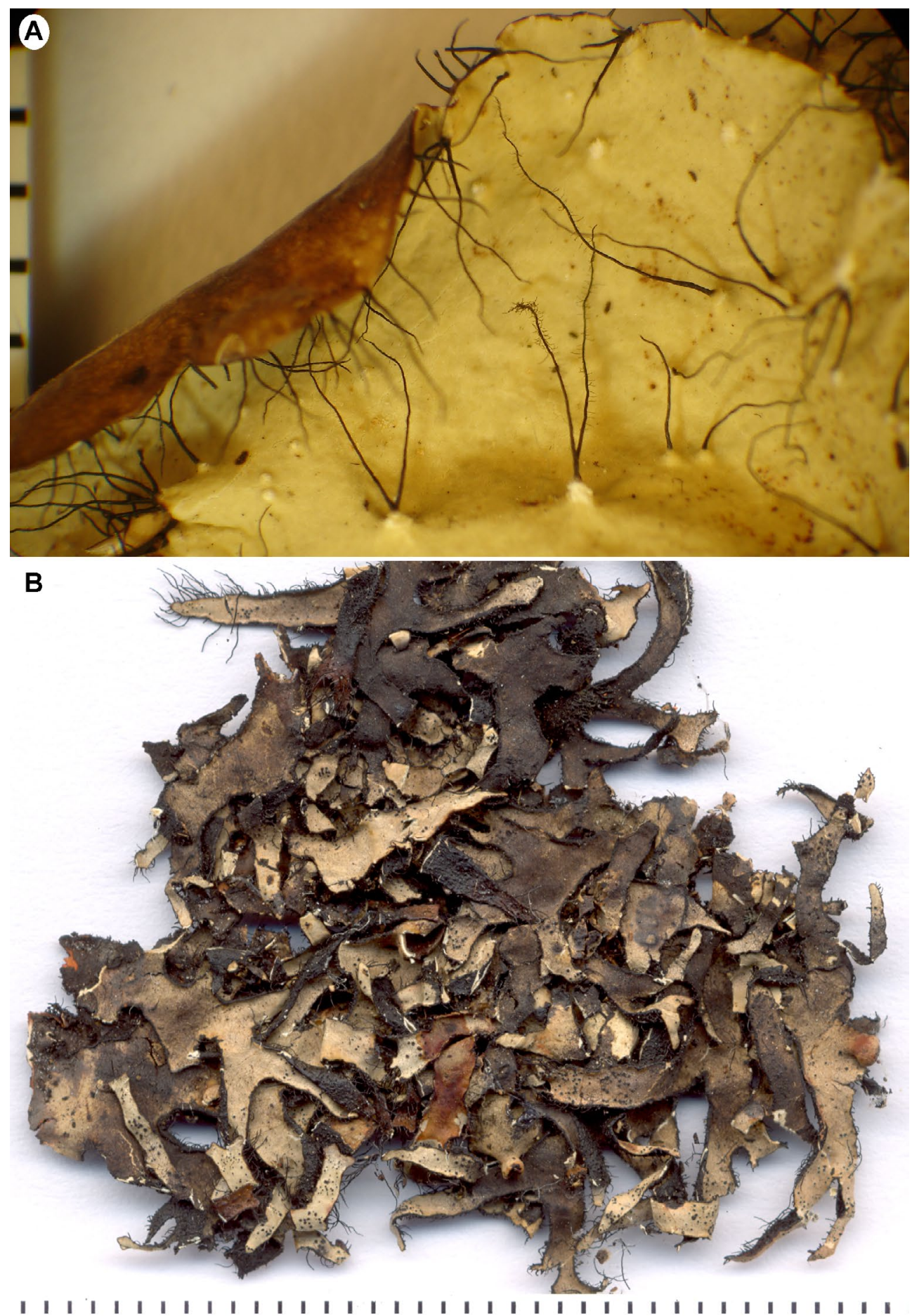

Figure 55. A - holotype of Parmotrema verrucisetosum (B), showing ciliate warts; B - hectotype of Parmotrema warmingii (M). Scales in milimeters.

abundant. Lacinulae, soredia and isidia absent. Medulla white. Undersurface black, lustrous, papillate to rugulose, with cracks; marginal zone dark brown, lustrous, $0.5-2.5 \mathrm{~mm}$ wide, rhizinate, with an attenuated limit, smooth; rhizines black, simple, usually entangled, up to $1.5 \mathrm{~mm}$ long, usually thin, rarely thickened, $0.01-0.15 \mathrm{~mm}$ wide, frequent, distributed in groups.

Apothecia cupuliform, 1-2.5 mm in diameter, sessile to substipitate, laminal or submarginal, margin incised, amphithecium maculate, smooth to irregular, disc dark brown, epruinose, imperforate; ascospores ellipsoid, 15-16 × 6-8 $\mu \mathrm{m}$, episporium 1-1.5 $\mu \mathrm{m}$. Pycnidia laminal, conspicuous, without prominent margin, abundant, ostiole black; conidia short-filiform, 6.5-10 $\times \sim 1 \mu \mathrm{m}$.

Chemistry. Atranorin (minor), chloroatranorin (trace), salazinic acid (major), consalazinic acid (minor). Cortex $\mathrm{K}+$ yellow, $\mathrm{UV}-$; medulla $\mathrm{K}+$ yellow $\rightarrow$ blood red, $\mathrm{C}-$, $\mathrm{KC}-, \mathrm{P}+$ strong yellow, $\mathrm{UV}-$.

Remarks. Parmotrema warmingii is characterized by the laciniate thallus with long cilia (up to $2.3 \mathrm{~mm}$ ) and the hypermaculate upper surface. It resembles $P$. herrei, a species here recognized and that can be differentiated by 
the branched, thickened cilia and the reticulate maculate upper surface (not hypermaculate). Another interesting feature of this lichen is the laminal distribution of the pycnidia. They are almost universally submarginal in the other species of parmotremoid lichens with salazinic acid.

The name Parmelia angustata (Krempelhuber 1873) is illegitimate since it is antedated by Parmelia angustata (in Gaudichaud-Beaupré1826) that now is Pannoparmelia angustata (Galloway 2007). Vainio (1890), aware of this situation, proposed the new name Parmelia warmingii Vain. to the taxon he recognized as distinct. This name was then used by Zahlbruckner $(1902,1909)$ for Brazilian lichens he studied and was also listed in the Catalogus Lichenum Universalis (Zahlbruckner 1930a).

Although Krempelhuber, Vainio and Zahlbruckner recognized this species, it was included by Hale and Fletcher (1990) as a synonym of Rimelia cetrata, based on a too broad species concept that included several taxa. Parmotrema cetratum is represented by a lobate thallus with lacinulae and distinct reticulate maculae (not hypermaculate) and with shorter cilia, up to $1.3 \mathrm{~mm}$ long.

The lectotype of Parmelia warmingii is well-preserved and agrees totally with the isolectotypes from $\mathrm{C}$ and $\mathrm{W}$, all being probably part of the same collection. The W duplicate has the more developed apothecia, one of them perforate. One specimen studied by Vainio (Lichenes brasiliensis exsiccati 1164, M) also has an imperforate apothecium. Therefore, the perforation seems to occur only in well-developed old apothecia.

Recent collections represented by more developed thalli (up to $10 \mathrm{~cm}$ broad) support the differential features of $P$. warmingii, mainly the laciniate thallus with long cilia, the hypermaculate upper surface and the well-developed black marginal line in the laciniae. Some specimens have little wider laciniae, like Canêz 2464 (up to $3.5 \mathrm{~mm}$ wide). The specimen Spielmann 2044 has well-developed perforate apothecia.

This species is known from Minas Gerais and São Paulo in Brazil, restricted to highlands (above $1200 \mathrm{~m}$ ). However, it it may occur in a wider area, since it was probably named as Parmotrema cetratum up to now. A good example is a specimen recently seen from South Africa (see below) that was earlier determined as Parmotrema cetratum by Hale (s.d.).

Distribution. Brazil, Minas Gerais (Krempelhuber 1873; Vainio 1890; Zahlbruckner 1902; Hale \& Fletcher 1990). Africa, South Africa (here reported).

Additional specimens examined. BRAZIL, Minas Gerais: [Municipality of Catas Altas], Caraça, 1885, Vainio Lichenes brasiliensis exsiccati 1164 (M); idem, at 'Cascudos', $20^{\circ} 05^{\prime} 38.7^{\prime \prime} \mathrm{S}, 43^{\circ} 30^{\prime} 00.3^{\prime \prime} \mathrm{W}, 1300 \mathrm{~m}$ alt., saxicolous, at the margin of the stream, partial sun, 27.III.2006, A.A. Spielmann, L.S. Canêz \& M.P. Marcelli 2009, 2017 (SP); idem, at 'Trilha para Capelinha', 2005'47.6"S, $43^{\circ} 29^{\prime} 06.4^{\prime \prime} \mathrm{W}, 1340 \mathrm{~m}$, saxicolous, shaded by a tree, A.A. Spielmann, L.S. Canêz \& M.P. Marcelli 2044 (SP), L.S. Canêz, A.A. Spielmann \& M.P. Marcelli 1550 (SP), idem, at 'Tanque Grande', 20 $06^{\circ} 10.1^{\prime} \mathrm{S}$, $43^{\circ} 29^{\prime} 38.4^{\prime \prime} \mathrm{W}, 1275 \mathrm{~m}$, saxicolous, slightly shaded, 04.IV.2006, A.A. Spielmann, L.S. Canêz \& M.P. Marcelli 2171 (SP). São
Paulo: Municipality of Piquete, Pico dos Marins, next to the first massif, $22^{\circ} 30^{\prime} 30.8^{\prime \prime} \mathrm{S}, 45^{\circ} 07^{\prime} 46.4^{\prime \prime} \mathrm{W}, 1.900 \mathrm{~m}$ alt., saxicolous, open place, 27.I.2007, L.S. Canêz, D.F. Peralta, J. Bordin \& J. Atwood 2464 (SP). AFRICA, South Africa, Transvaal., Distr. Pilgrims Rest, 4 miles S.E. of P.R., on rocks near road, 22.X.1953, O. Almborn 7810 (L).

\section{Nomina inquirenda}

The following names are untypifiable because the type specimens are presumed lost, unavailable, or too fragmentary for study.

Lichen perlatus $\alpha$ ciliatus Lam. \& DC., Flore Française 2: 403.1805 .

Type: France. Vire: Delise s.n. (lectotype - G, designated by Hale \& Fletcher 1990).

$\equiv$ Parmelia perlata g ciliata (Lam. \& DC) Duby, Bot. Gall. 2: 601.1830 .

三 Parmelia perlata var. tentaculata Wallr., Fl. Crypt. Germ. 3: 521. 1831. Based on Lichen perlatus $\alpha$ ciliatus.

$\equiv$ Parmelia ciliata (Lam. \& DC) Nyl., Flora 61: 247. 1878.

$\equiv$ Parmelia perlata var. ciliata (Lam. \& DC) Jatta, Fl. Ital. Crypt. 3: 206. 1909.

三 Parmelia ciliata (Lam. \& DC) Fink, Proc. Indiana Acad. Sci. 1918: 268. 1919. Superfluous combination, according to Hale \& Fletcher (1990).

$\equiv$ Lobaria perlata [beta] ciliata Lam. \& DC, according to B. Hale \& DePriest (1999).

Remarks. The lectotype of this species was not found in G. However, the curator (Philippe Clerc) kindly sent one specimen labeled 'Parmelia perlata var. ciliata Delise' from Vire. This is a well-developed lichen with ciliate isidia and the following chemistry (TLC in solvent C, HPLC): atranorin (minor), chloroatranorin (trace), stictic acid (major), cryptostictic acid (minor), constictic acid (minor), peristictic acid (trace), menegazziaic acid (minor) and norstictic acid (trace). The real identity is beyond the scope of the present work, but it is probably Parmotrema crinitum. Since there are no annotations from Hale (or anyone else) with the specimen and it clearly does not belong to Parmotrema reticulatum. The name Lichen perlatus $\alpha$ ciliatus remains to be clarified in the future.

Parmelia badia Pers., in Gaudichaud-Beaupré, Voyage autour du monde, exécuté sur les corvettes l'Uranie et la Physcienne, sur les ordres du Cap. L. de Freycinet, en 1817-1820, Botanique, p. 198. 1826.

(Fig. 56A)

Type: Hawaiian Islands: Gaudichaud 78 (lectotype - PC!; isolectotypes - BM, G).

Remarks. Although well preserved and not small, the lectotype (PC) is represented by a possibly burnt, poorly prepared thallus (like Parmelia maura, see below), without apothecia or pycnidia. It has very similar sorediate lobes to Parmotrema cristiferum, and the chemistry needs to be revisited. If it proves to have salazinic acid, the name Parmelia badia takes precedence over Parmelia cristifera. In the sheet of the lectotype of Parmelia badia $(\mathrm{P})$, there is a label indicating the number 79 and 'Parmelia flexuosa Delise, Parmelia badia Pers.'. The name 
Parmelia flexuosa was not found in any catalogue (Zahlbruckner1934, Lamb 1963, Index Fungorum 2009) and was possibly never published.

Parmelia cetrata f. sorediifera Vain., Acta Societatis pro Fauna et Flora Fennica 7(1): 40. 1890.

Type: Brazil. Minas Gerais: Sitio [now Antonio Carlos Municipality], Vainio, Lichenes Brasilienses Exsiccati 616 (lectotype - TUR-V!).

Remarks. This taxon is represented by a small $(2.5 \mathrm{~cm}$ broad), not well-developed thallus (it is an oligotype) without apothecia and pycnidia growing with a fertile Hypotrachyna. It has short open lacinulae, sorediate at the apices. The soralia also develop submarginally, turning the lobes concave. This is the pattern we found in many Brazilian specimens we previously named Parmotrema clavuliferum (Spielmann 2005; Benatti 2005; Jungbluth 2006) and, in respect to the submarginal soralia and short, open lacinulae, they are clearly different from the type of Parmelia clavulifera. Conidial and ascospore features could not be studied to clarify the status of this taxon, as well the chemistry, since it is an oligotype.
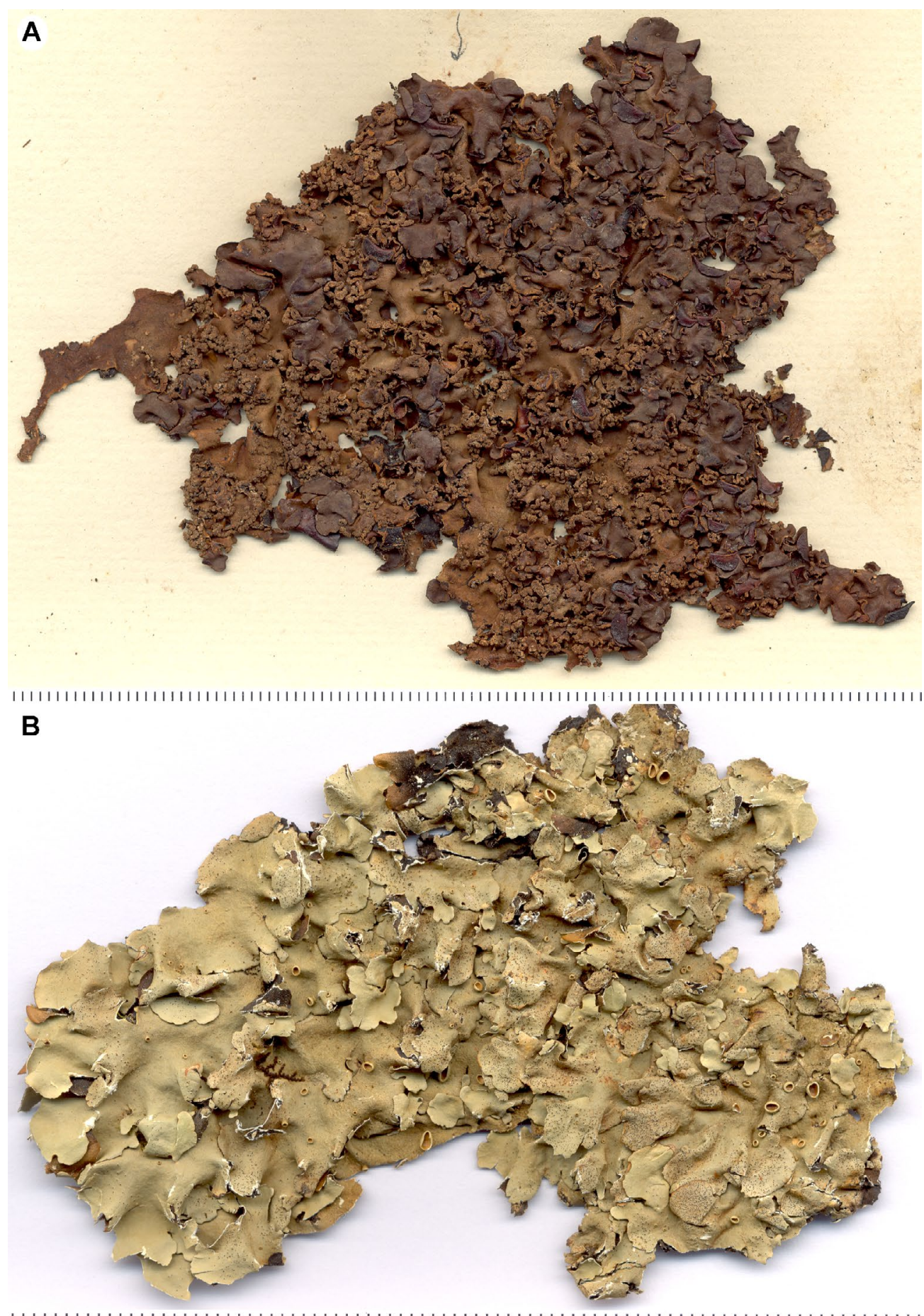

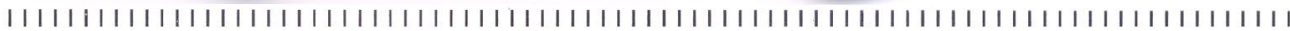

Figure 56. A - hectotype of Parmelia badia (PC); B - holotype of Parmelinella afrocetrata (B). Scales in milimeters. 
Parmelia cetrata var. sorediifera f. platyloba Vain., The Botanical Magazine Tokyo 32: 154. 1918.

Type: Japan, Kōzuke: in rupe, 03.III.1914, A. Yasuda 107 (holotype - TUR!).

Remarks. Vainio (1918) proposed this taxon based on the wider and plane lobes. In fact, the holotype has lobes that reach $16 \mathrm{~mm}$ wide. However, this is the only specimen known, and since apothecia and pycnidia are lacking, it is impossible to determine the features of the ascospores and conidia at present. As these characters have shown to be important in the resolution of taxonomical problems involving another species in this group, we are reticent to accept its status as synonym of Parmotrema reticulatum (as proposed by Hale \& Fletcher 1990) until fertile specimens could be found and examined. Its chemistry also did not help in further conclusions: atranorin (minor), chloroatranorin (trace), salazinic acid (major), consalazinic acid (minor).

Parmelia cinerascens var. saxicola Räsänen, Suom. Eläin.Kasv. Seuran Vanamo 2: 45. 1947.

Type: Uruguay. Pan de Azucar: Maldonado, Lamb (lectotype - H), according to Hale \& Fletcher (1990).

Remarks. We did not observe this type. This taxon was listed as synonym of Parmotrema cetratum by Hale \& Fletcher (1990).

Parmelia cristifera f. cinerata Zahlbr., Repertorium species novarum Fedde 33: 58. 1934.

Type: Taiwan. Kuwarus: Asahina 51 (holotype - W; isotype - BPI), according to Hale (1965).

Remarks. The holotype was not sent by W and the Herbarium Manager of BPI, Dr. Erin B. McCray, informed us (pers. comm.) that the herbarium does not have any specimens filed as Parmelia.

Parmelia gossweileri C.W. Dodge, Annals of the Missouri Botanical Garden 46: 153. 1959.

Type: Angola. Chiloango: Gossweiler 8091e (holotype - K), according to Hale (1965).

Remarks. The holotype could not be found in K. This species was listed as a synonym of Parmelia cristifera (Hale 1965).

Parmelia imerinensis C.W. Dodge, Annals of the Missouri Botanical Garden 46: 143. 1959.

Type: Madagascar. East Imerina: Hildebrandt (holotype - FH!).

Holotype description. Thallus beige (herbarium), probably greenish-gray when fresh, lobate, loosely adnate, corticicolous, $16 \mathrm{~cm}$ broad. Lobes irregularly branched, laterally overlapped, 5-13 mm wide., surface usually smooth, lustrous, extensively damaged and finely rugose; apical zone rounded; margin smooth or crenate, undulated. Cilia absent (three small formations seen, but probably rhizines). Lacinulae, maculae, isidia and pustules absent.
Soralia concolor to the thallus or whitish, usually linear and marginal, less frequently capitate and growing in the lobe crests; soredia granular. Medulla white. Undersurface black, lustrous, smooth or slightly rugose, with scars; marginal zone brown, lustrous, up to $6 \mathrm{~mm}$ wide, naked, with an attenuated limit, smooth, rugose or papillate; rhizines black, simple (few observed).

Apothecia and pycnidia absent.

Chemistry (TLC in solvent C, HPLC, J.A. Elix, 03.XI.1998). Atranorin (minor), chloroatranorin (trace), salazinic acid (major), consalazinic acid (minor), methyl pseudosalazinate, unknowns (minor/trace). Cortex $\mathrm{K}+$ yellow, UV-; medulla $\mathrm{K}+$ yellow $\rightarrow$ blood red, $\mathrm{C}-$, $\mathrm{KC}-$, $\mathrm{P}+$ strong yellow, UV-.

Remarks. Parmelia imerinensis was proposed by Dodge (1959) based on a peculiar cortical structure. The holotype is represented by a thallus with the upper cortex extensively damaged, eroded, that give it an appearance of finely rugose/granulose. In one area, the surface seems maculated, but has no maculae in the rest.

Since apothecia and pycnidia were not found, the status of Parmelia imerinensis remains unclear. There is a chemical difference between $P$. imerinensis and Parmotrema cristiferum, since the latter contains eumitrins. Morphologically, there are much more laminal soralia in $P$. imerinensis, and the marginal ones are not as crisped as in $P$. cristifera. On the other hand, cilia are absent, making this name not conspecific with Parmotrema sieberi.

The holotype is glued by the underside, so the observations were limited to the free margins.

One of the specimens determined by Dodge (label dated 1957) is clearly another species, since it does not have salazinic acid (medulla $\mathrm{K}+$ slowly yellowish), but probably protocetraric acid (Hildur Krog's label, TLC, 19..). Actually, this is the holotype of Parmelia paxinoides C.W. Dodge (see Dodge 1959). The data from the protologue agree very well with the specimen.

Parmelia maura Pers., in Gaudichaud-Beaupré, Voyage autour du monde, exécuté sur les corvettes l’Uranie et la Physcienne, sur les ordres du Cap. L. de Freycinet, en 1817-1820, Botanique, p. 198. 1826.

Type: Hawaiian Islands: Gaudichaud (lectotype - L!; isolectotype - H-NYL 35280!).

Remarks. The lectotype (L), collected in the Hawaiian Islands, is represented by an apparently burnt thallus. It contains only atranorin [minor] and chloroatranorin [major] (TLC in solvent C, HPLC - J.A. Elix, May 2009). The ascospores are ellipsoid, $16-20 \times 10-12 \mu \mathrm{m}$, episporium 1-1.5 $\mu \mathrm{m}$. Conidia were not found in this specimen, but the isolectotype (H-NYL 35280!) revealed filiform conidia, 12-16.5 $\times \sim 1 \mu \mathrm{m}$. Those features exclude this taxon as a synonym of Parmotrema cetratum (Hale $\&$ Fletcher 1990), especially the absence of salazinic acid. Otherwise, it may close to P. macrocarpum (Pers.) Hale (see also Hale \& Fletcher 1990). Studies on the type of this species and its synonym Parmelia macrocarpoides Vain. were not yet performed. 
Parmelia menziesii C.W. Dodge, Annals of the Missouri Botanical Garden 46: 101. 1959.

Type: Cape of Good Hope. Menzies s.n. (holotype - FHTuck!). Not Parmelia menziesii Ach., Meth. Lich. 221. 1803 (= Leptogium).

Remarks. The holotype (FH), from Cape of Good Hope, presents apothecia $1-4 \mathrm{~mm}$ in diameter that are concave or urceolate, stipitate, laminal, with maculate amphithecium, disc brown, epruinose, imperforate, and immature ascospores ellipsoid 15-18 × $10 \mu \mathrm{m}$, with episporium $\sim 2 \mu \mathrm{m}$. The pycnidia are submarginal, conspicuous, without prominent margin, frequent, ostiole black, conidia filiform, $12-16 \times \sim 1 \mu \mathrm{m}$. The cortex is $\mathrm{K}+$ yellow, $\mathrm{UV}-$, and the medulla $\mathrm{K}+$ yellow $\rightarrow$ blood red, $\mathrm{C}-, \mathrm{KC}-, \mathrm{P}+$ strong yellow, $\mathrm{UV}-$, so attesting the presence of salazinic acid. The more salient difference of this species is supposedly conidial, but the observations we made do not match the protologue (conidia bacillary, $5-6 \times 1 \mu \mathrm{m}$, according to Dodge 1959). The remaining morphology is difficult to evaluate due to the very fragmentary status of the type, devoid of well-developed apothecia, etc. Actually, there are only three parts from one (or more) thallus glued on a paper and only immature ascospores were found in the larger apothecium. They revealed similar measurements as described by Dodge (1959). Hale and Fletcher (1990) listed this species as a synonym of Parmotrema cetratum. However, attention should be placed in the imperforate apothecia, since in Parmotrema cetratum they are clearly perforate. It is possible they are so because they are immature, and so it seems convenient to maintain Parmelia menziesii as a nomen inquirendum until more specimens from the type locality are studied.

Parmotrema moreliense (B. de Lesd.) W.L. Culb. \& C.F. Culb., The Bryologist 84(3): 310. 1981.

Basionym: Parmelia moreliensis B. de Lesd., Lichens du Mexique: 5. 1914.

Type: Mexico. Michoacan: Morelia, Campanario No 4400 sur écorce (Bouly de Lesdain 1914).

E Everniastrum moreliense (B. de Lesd.) Hale, Mycotaxon 3(3): 348. 1976.

Remarks. This type was not located, because the information about the type and where it is located was not supplied by Bouly de Lesdain (1914), Culberson \& Culberson (1981), Hale (1976) or Egan et al. (2016).

Parmelia perforata var. ciliata Sambo, Contributi Scientifici delle Missioni Salesiane del Beato Don Bosco, Torino 6: 45. 1930.

Type: Argentina. Patagonia: Pampa, General Acha, 25-IV1910, Macchi (holotype - supposedly in RO) [non Parmelia perforata (Jacquin) Ach. var. ciliata Nyl.], according to Hale (1965).

Remarks. Through the short description and unclear illustration in the protologue (Sambo 1930), we cannot conclude the present status of this variety. Although we requested the loan of the holotype of Parmelia perforata var. ciliata Sambo from the RO Herbarium, this species was not included in that collection. Apparently, Maria Cengia Sambo collaborated with the Institute of Botany in Florence and she left her collections to the Herbarium Centrale Italicum. So maybe the type is deposited in the Museo di Storia Naturale of Florence (A. Millozza, pers. comm.).

Parmelia perforata var. microspora Räsänen, Suom. Eläin.Kasv. Seuran Vanamo 2: 45. 1947.

Type: Argentina. Tucumán: San Xavier, Herrera 2519 (lectotype - H), according to Hale \& Fletcher (1990).

Remarks. The type could not be found in H. This taxon was listed as a synonym of Parmotrema cetratum by Hale \& Fletcher (1990).

Parmelia perforata var. replicata Meyen \& Flotow, Novorum Actorum Academiae Caesareae LeopoldinoCarolinae Naturae Curiosorum Vol. 19, Supplementum 1: 218.1843.

Type: Brazil. Rio de Janeiro: near Rio de Janeiro city, saxicolous (lectotype - G!, designated by Hale \& Fletcher 1990).

Remarks. Meyen \& Flotow (1843), while describing this species, published a full color illustration of a well-developed lichen with several apothecia. The specimen preserved in $\mathrm{G}$ is represented by just one apothecium and a tiny part of the thallus: justifiably it was denominated as oligotype. Its chemistry is as follows: atranorin (minor), chloroatranorin (trace), salazinic acid (major), and consalazinic acid (minor). It undoubtedly belongs to the group of specimens frequently named as Parmotrema cetratum. Nevertheless, the apothecia showed in the color illustration are mainly imperforate apothecia, and this feature is difficult to evaluate in the lectotype. Additionally, the apothecium in the lectotype is dentate to short-lacinulate, a character up to now not known in $P$. cetratum, although we are aware this feature was present in some specimens seen (although not gathered) at the Caraça region, Minas Gerais. Several pycnidia were also examined, but they were all empty.

\section{Parmelia polita Fr., Syst. Orb. Veg. 1: 283. 1825.}

Type: USA North Carolina: Schweinitz (lectotype - UPS). 'As Müller Argoviensis (Flora 70: 318. 1887) noted, the published locality (Cape, South Africa) cited by Fries is incorrect', according to Hale \& Fletcher (1990).

Remarks. The type was not sent by UPS. This taxon was listed as synonym of Parmotrema cetratum by Hale \& Fletcher (1990).

\section{Excluded name}

Parmelinella afrocetrata (Elix, Fischer \& Killmann) Marcelli \& Spielmann, comb. nov.

(Fig. 56B)

MycoBank MB 838197 
Basionym: Parmotrema afrocetratum Elix, Fischer \& Killmann, The Lichenologist 37(2): 103. 2005.

Type: Rwanda. Butare: park of the Institut de Recherche Scientifique et Technologique, c. $1750 \mathrm{~m}$ alt., on rocks, 14.X.1999, E. Fischer, s.n. (holotype - B!; isotype - CANB).

Holotype description. Thallus yellowish gray, lobate, loosely adnate, over rocks with debris, $8 \mathrm{~cm}$ broad. Lobes irregularly branched, crowded, 4-8.5 mm wide, surface continuous or irregularly cracked, smooth, lustrous or opaque, becoming reticulate cracked towards the center; apical zone rounded; margin smooth to crenate or irregular, undulated. Maculae weak or indistinct, irregular, laminal. Cilia simple, rare in the axils, very small, up to $0.1 \times$ $0.02 \mathrm{~mm}$. Lacinulae, pustules, soredia and isidia absent. Medulla white. Undersurface black, lustrous, papillate or rugose, with cracks; marginal zone brown, lustrous, 2-4 mm wide, rhizinate, with an attenuated limit, rugose or papillate, or rarely with veins; rhizines concolor to the undersurface, simple or rarely branched, frequently with penicillate whitish apices when in the marginal zone, short and thin, up to $0.5 \mathrm{~mm}$ long, $0.01-0.04 \mathrm{~mm}$ wide, abundant, evenly distributed.

Apothecia cupuliform, $0.5-2 \mathrm{~mm}$ in diameter, stipitate, laminal, margin smooth or sometimes with a profound incision, amphithecium smooth, disc brown, epruinose, imperforate; ascospores ellipsoid, 8.5-9 × 6-6.5 $\mu \mathrm{m}$, episporium $0.5-1 \mu \mathrm{m}$. Pycnidia laminal, conspicuous, usually with prominent margin, abundant, ostiole black; conidia sublageniform, 5-7.5 $\times \sim 1 \mu \mathrm{m}$.

Chemistry (TLC in solvent C, J.A. Elix, 21.X.2003, label with the holotype). Atranorin (minor), salazinic acid (major), consalazinic acid (minor). Cortex $\mathrm{K}+$ yellow, $\mathrm{UV}-$; medulla $\mathrm{K}+$ yellow $\rightarrow$ blood red, $\mathrm{C}-, \mathrm{KC}-, \mathrm{P}+$ strong yellow, UV-.

Remarks. The rarely ciliate (only in the axils) lobes, imperforate apothecia, small ascospores, conidia sublageniform, medulla with salazinic and consalazinic acid and overall morphology, including the rhizines that develop a penicillate whitish apex when growing near the marginal zone, are indicatives that this species does not belong to Parmotrema, being more adequately treated under Parmelinella Elix \& Hale.

Benatti \& Marcelli (2007) provided a worldwide key to this genus, and two species with a brown marginal zone could be compared: P. manipurenses is the only known saxicolous species, has larger ascospores 9-14 $\mu \mathrm{m}$ and smaller conidia 2-4 $\mu \mathrm{m}$ (Singh 1980), while the corticicolous $P$. simplicior has smaller ascospores $6 \times 4 \mu \mathrm{m}$ and also shorter conidia 2-3 $\mu \mathrm{m}$ (Hale 1972).

This seems to be the first species in Parmelinella with sublageniform conidia.

Although in the protologue the substrate was described as saxicolous, the holotype has several wood pieces in the underside, as well as mosses and soil. This can indicate the thallus was growing on debris on rocks.

Distribution. Africa, Rwanda (Elix et al. 2005, Bock et al. 2007).

\section{Acknowledgments}

To FAPESP (Fundação de Amparo à Pesquisa do Estado de São Paulo, Process n ${ }^{\circ}$ 05/53740-5) and CAPES (Coordenação de Aperfeiçoamento de Pessoal de Nível Superior) for the grants received, and to the Programa de Pós-graduação em Biodiversidade Vegetal e Meio Ambiente, Instituto de Botânica de São Paulo (IBt), for the opportunity and support. We are especially grateful to the curators and investigators of the following herbaria who kindly sent specimens and helped in many ways: Dr. Thomas Nash III (ASU), Dr. Harrie Sipman (B), Dr. Mónica T. Adler, Dr. Alejandra Fazio and Dr. Andrea Romero (BAFC), Dr. Scott LaGreca, Dr. Rob Huxley and Dr. Holger Thüs (BM), Dr. Eric Hansen Steen (C), Dr. Christine Cargill and Dr. Brendan Lepschi (CANB), Dr. Aaron Wilton and Dr. Mary Korver (CHR), Dr. Tom Ranker and Dr. Tim Hogan (COLO), Dr. Lidia I. Ferraro and Dr. María Mercedes Arbo (CTES), Dr. François Lutzoni, Dr. Molly McMullen and Dr. Kathleen Pryer (DUKE), Dr. Robert Lücking (F), Dr. Piero Cuccuini (FI), Dr. Philippe Clerc (G), Dr. Leena Myllys and Dr. Soili Stenroos (H), Dr. Simon Owens, Dr. Angela Bond and Dr. Donney Nicholson (K), Dr. Erik Smets and Dr. Nicolien Sol (L), Dr. Arne Thell and Dr. Ingvar Kärnefelt (LD). Dr. Andreas Beck (M), Dr. Clifford Wetmore and Dr. Imke Schmitt (MIN), Dr. Alan Fryday (MSC), Dr. Einar Timdal (O), Dr. Bruno Denetière and Dr. Marc Pignal (PC), Dr. Kevin Thiele and Dr. Nicholas S. Lander (PERTH), Dr. Anna Millozza (RO), Dr. Anders Tehler and Dr. Marianne Hamnede (S), Dr. Hiroyuki Kashiwadani and Dr. Yoshihito Ohmura (TNS), Dr. Seppo Huhtinen (TUR), Dr. Anders Nordin, Dr. Mats Hjerstson and Dr. Monika Myrdal (UPS), Dr. Sionara Eliasaro (UPCB), Dr. Gregory McKee and Dr. Leonard Hirsch (US), Dr. Uwe Passauer and Dr. Othmar Breuss (W), and Dr. Walter Till (WU).

The FH Herbarium gave the first author a great opportunity to visit Harvard University to study the collections in loco. We are obliged to Dr. Donald H. Pfister, Dr. Emily Wood, and also the Librarian Judith A. Warnement and all of her very efficient team. To Dr. Michaela Schmull, a special thank you for all the kindness, patience and interest in our research, as well as for sending pictures of the specimens.

Dr. J.A. Elix kindly performed most of the chemical analyses on the types and the new name Parmotrema elixii is only a small part of what we can offer for him. Thank you very much Jack!

The American Bryological and Lichenological Society ABLS and International Association for Lichenology - IAL, are specially acknowledged for their help in enabling the visit to the USA and to attend the IAL - 6 Congress at Asilomar, California. Dr. Thomas (Tom) Nash III is warmly thanked.

Dr. Robert Lücking \& Dr. Eimy Rivas Plata provided all of the support and dedication that made possible a short stay at Chicago (F), as well as Dr. Thorsten Lumbsch. Dr. Mónica Adler, Dr. Lidia Ferraro and Dr. Sionara Eliasaro, always quickly and helpfully replied to our solicitations.

To all lichenologists that sent literature throughout the years, thank you so much for your help! We must mention Drs. Robert Lücking, Teuvo Ahti, Hiroyuki Kashiwadani, Philippe Clerc, John Elix, Klaus Kalb and Mónica Adler.

The Librarian of the Instituto de Botânica, Maria Helena Simões Costa Fernandes Gallo, always keeps the doors opened to our requests, helping in the search and acquisition of much old and important literature. Dr. Neli Kika Honda, from the Universidade Federal do Mato Grosso do Sul (UFMS), assisted us in an earlier workshop on lichen chemistry and helped with chemical information.

Dr. Michel Navarro Benatti, curator of the Lichen Herbarium of SP, managed our loan requests very well and always tried to solve the many problems encountered. 


\section{Supplementary electronic material}

File S1. Protocol for description of parmotremoid lichens with salazinic acid. Download file

\section{References}

Acharius, E. 1803. Methodus qua omnes detectos lichenes. Stockholm.

Acharius, E. 1814. Synopsis Methodica Lichenum. Lund.

Adler, M. T. 1988. La familia Parmeliaceae (Líquenes, Ascomycotina) en la Provincia de Buenos Aires: Estudio taxonómico-florístico. Tesis presentada para optar al título de Doctora en Ciencias Biológicas, Universidad de Buenos Aires.

Adler, M. T. 1992. Clave de los géneros y de las especies de Parmeliaceae (Lichenes, Ascomycotina) de la Provincia de Buenos Aires (Argentina). Boletín de la Sociedad Argentina de Botánica 28: $11-17$

Adler, M. T. \& Elix, J. A. 1987. Three new saxicolous species in Parmeliaceae (lichenized Ascomycotina) from Argentina. Mycotaxon 30: 339-344.

Aguirre-C, J. \& Rangel-CH, J. O. 2007. Amenazas a la conservación de las especies de musgos y líquenes en Colombia - una aproximación inicial. Caldasia 29: 235-262.

Ahn, C. \& Moon, K. H. 2016. Parmotrema clavuliferum and P. reticulatum are independent species. Journal of Species Research 5: 254-260.

Ahti, T. \& Marcelli, M. P. 1995. Taxonomy of the Cladonia verticillaris complex in South America. Bibliotheca Lichenologica 58: 5-26.

Aptroot, A. 1991. Lichens of Madagascar: new records and species of Parmeliaceae. Cryptogamie, Bryologie-Lichenologie 12(2): 149-154.

Aptroot, A. 2008. Checklist of lichens and lichenicolous fungi of Madagascar. http://www.biologie.uni-hamburg.de/checklists/africa/ madagascar_l.htm

Asahina, Y. 1940. Lichenologische Notizen XIV. Journal of Japanese Botany 16: 592-603.

Asahina, Y. 1952. Lichens of Japan. Vol. II. Genus Parmelia. Research Institute for Natural Resources, Shinjuku, Tokyo.

Asahina, Y. \& Shibata, S. 1954. Chemistry of Lichen Substances. Japanese Society for the Promotion of Science, Tokyo.

Awasthi, D. D. 1976. Lichen genus Parmelia in India I - Subgenera Parmelia and Amphigymnia. Biological Memoirs, Lichenology Series 1: 155-229.

Barros, L. M. de \& Xavier Filho, L. 1972. Catálogo dos liquens do Herbário do Departamento de Botânica da Universidade Federal de Pernambuco. Anais do XXIII Congresso Nacional de Botânica (Garanhuns, PE): 45-55.

Benatti, M. N. 2005. Os gêneros Canomaculina, Parmotrema e Rimelia (Parmeliaceae, Ascomycetes) no litoral centro-sul do Estado de São Paulo. Dissertação (mestrado). Instituto de Botânica da Secretaria de Estado do Meio Ambiente. São Paulo.

Benatti, M. N. \& Marcelli, M. P. 2007. Worldwide key for Parmelinella Elix \& Hale (Parmeliaceae, lichenized Ascomycota). In: Anais da Segunda Reunião Brasileira de Estudos Liquenológicos (2a REBEL). Porto Alegre - RS: Grupo de Estudos Liquenológicos - FZB, v.1: 62-68.

Benatti, M. N. \& Marcelli, M. P. 2008. Espécies de Parmotrema (Parmeliaceae, Ascomycetes liquenizados) com máculas reticulares do litoral centro-sul do Estado de São Paulo, Brasil. Hoehnea 35: 75-90.

Benatti, M. N., Marcelli, M. P. \& Elix, J. A. 2008. Three new species of Parmotrema containing salazinic acid from the coast of São Paulo State, southeastern Brazil. Mycotaxon 103: 41-52.

Berry, E. C. 1941. A monograph of the genus Parmelia in North America, North of Mexico. Annals of the Missouri Botanical Garden 28: 31-146.
Blanco, O., Crespo, A., Divakar, P. K., Elix, J. A. \& Lumbsch, H. T. 2005. Molecular phylogeny of parmotremoid lichens (Ascomycota, Parmeliaceae). Mycologia 97: 150-159.

Bock, C., Hauck, M. \& Fischer, E. 2007. The lichen flora of Rwanda: an annotated checklist. Willdenowia 37: 563-575.

Bouly de Lesdain, M. 1914. Lichens du Mexique (états de Puebla et du Michoacan) recueillis par le frère Arsène Brouard. Imp. I. Escalante, S.A., Mexico.

Brodo, I. M. 1965. [Review] M. E. Hale, Jr. A monograph of Parmelia subgenus Amphigymnia. Contributions from the United States National Herbarium 36: 193-358. 29 fig. 16 pl. The Bryologist 68: 374.

Brodo, I. M., Sharnoff, S. D. \& Sharnoff, S. 2001. Lichens of North America. Yale University Press, New Haven \& London.

Bungartz, F. 2001. Analysis of lichen substances. http://nhc.asu.edu/ lichens/lichen_info/tlc.jsp [accessed in June 2009]

Bungartz, F. \& Spielmann, A. A. 2019. The genus Parmotrema (Parmeliaceae, Lecanoromycetes) in the Galapagos Islands. Plant and Fungal Systematics 64: 173-231.

Buril, M. L. L. 2015. Levantamento de liquens foliosos (Parmeliaceae) do semiárido de Pernambuco - NE, Brasil. Tese (doutorado). Universidade Federal de Pernambuco.

Calvello, S. \& Liberatore, S. 2002. Catálogo de los Líquenes de la Argentina. Kurtziana 29: 7-170.

Canêz, L. S. 2005. A família Parmeliaceae na localidade de Fazenda da Estrela, município de Vacaria, Rio Grande do Sul, Brasil. Dissertação (mestrado). Instituto de Botânica da Secretaria de Estado do Meio Ambiente. São Paulo.

Canêz, L. S. \& Marcelli, M. P. 2006. Gêneros de Parmeliaceae (Ascomycetes liquenizados) na localidade de Fazenda da Estrela, Vacaria, Rio Grande do Sul, Brasil. Caderno de Pesquisa Série Biologia (Santa Cruz do Sul) 18: 38-81.

Cengia-Sambo, M. 1930. Licheni della Patagonia e di altre regioni dell' Argentina raccolti dai missionari salesiani. Contributi Scientifici delle Missioni Salesiane del Beato Don Bosco, Torino 6: 1-73, 2 maps, 9 pl.

Cengia-Sambo, M. 1939a. Lichenes. In: Cufodontis, G. Missione Biologica nel paese dei Borana. IV, p. 375-389. Raccolte Botaniche. R. Acad. Italiana Centro Studi Africa Orient. Ital.

Cengia-sambo, M. 1939b. Licheni dell’ Africa Orientali Italiana dal Console prof. Senni e dal Centurione ing. Giordano, Ufficiali della Milizia Nazionale Forestale di Addis Abeba nel 1937. Nuovo Giornale Botanico Italiano, n. ser. 46: 437-455.

Cengia-Sambo, M. 1939c. Licheni del Brasile. Annali di Botanica 22: 19-41.

Chen, J-B., Wang, S-L. \& Elix, J. A. 2003. Parmeliaceae (Ascomycota) lichens in China's Mainland I. The genera Canomaculina, Parmelina, Parmelinella and Parmelinopsis. Mycotaxon 86: 19-29.

Chen, J-B., Wang, S-L. \& Elix, J. A. 2005. Parmeliaceae (Ascomycota) lichens in China's Mainland III. The genus Parmotrema. Mycotaxon 91: 93-113.

Choisy, M. 1931. Lichens nouveaux. Bulletin de la Société Botanique de France 78: 453-460.

Choisy, M. 1952. Catalogue des lichens de la region lyonnaise. Fasc. 9. Bulletin mensuel de la Société Linnéenne de Lyon et des Société Botanique de Lyon 21: 165-180.

Christensen, S. N. \& Sipman, H. J. M. 1998. Silver moss - ornamental lichens from Brazil. British Lichen Society Bulletin 82: 11-13.

Culberson, W. L. \& Culberson, C. F. 1981. The genera Cetrariastrum and Concamerella (Parmeliaceae): a chemosystematic synopsis. The Bryologist 84: 273-314.

Culberson, W. L. 1973. The Parmelia perforata group: niche characteristics of chemical races, speciation by parallel evolution, and a new taxonomy. The Bryologist 76: 20-29. 
Cunha-Dias, I. P. R. 212. A família Parmeliaceae (fungos liquenizados) na região tocantina: ocorrência e potencial econômico/medicinal. Tese (doutorado). Universidade Federal de Pernambuco.

Del-Prado, R., Divakar, P. K. \& Crespo, A. 2011. Using genetic distances in addition to ITS molecular phylogeny to identify potential species in the Parmotrema reticulatum complex: a case study. The Lichenologist 43: 569-583.

Del-Prado R., Divakar, P. K., Lumbsch, H. T. \& Crespo, A. M. 2016. Hidden Genetic Diversity in an Asexually Reproducing Lichen Forming Fungal Group. PLoS ONE 11: e0161031.

Dey, J. P. 1978. Fruticose and foliose lichens of the High-Mountain Areas of the Southern Appalachians. The Bryologist 81: 1-93.

Divakar, P. K. \& Upreti, D. K. 2005. Parmelioid Lichens in India (a revisionary study). Bishen Singh Mahendra Pal Singh, Dehra Dun, India.

Divakar, P. K., Upreti, D. K. \& Elix, J. A. 2001. New species and new records in the lichen family Parmeliaceae (Ascomycotina) from India. Mycotaxon 80: 355-362.

Divakar, P. K., Blanco, O., Hawksworth, D. L. \& Crespo, A. 2005. Molecular phylogenetic studies on the Parmotrema reticulatum (syn. Rimelia reticulata) complex, including the confirmation of $P$. pseudoreticulatum as a distinct species. The Lichenologist 37: 55-65.

Divakar, P. K., Crespo, A., Núñez-Zapata, J., Flakus, A., Sipman, H. J. M., Elix, J. A. \& Lumbsch H. T. 2013. A molecular perspective on generic concepts in the Hypotrachyna clade (Parmeliaceae, Ascomycota). Phytotaxa 132: 21-38.

Dodge, C. W. \& Baker, G. E. 1938. The Second Byrd Antarctic Expedition. Botany. II. Lichens and lichen parasites. Annals of the Missouri Botanical Garden 25: 515-718.

Dodge, C. W. 1957. Lichens. In Julian A. Steyermark and collaborators, Contributions to the Flora of Venezuela. Fieldiana: Botany 28: 690-695.

Dodge, C. W. 1959. Some lichens of Tropical Africa, III. Parmeliaceae. Annals of the Missouri Botanical Garden 46: 39-193.

Donha, C. G. 2005. Os gêneros Canomaculina, Parmotrema e Rimelia (Ascomycota liquenizados, Parmeliaceae) na área de proteção ambiental de Guaraqueçaba - Paraná - Brasil. Dissertação (mestrado). Universidade Federal do Paraná. Curitiba.

Duby, J. E. 1830. Synopsis Plantarum in Flora Gallica descriptarum. 2a ed. Pars II: plantas cellulares continens. Paris: Desray.

Du Rietz, G. E. 1924a. Die soredien und isidien der Flechten. Svensk Botanisk Tidskrift 18: 371-396.

Du Rietz, G. E. 1924b. Kritische Bemerkungen über die Parmelia perlata-Gruppe. Nyt Magazin for Naturvidenskaberne 62: 63-82.

Egan, R. S. 1982. Parmotrema arteagum, a new lichen species from Mexico. The Bryologist 85: 79-83.

Egan, R. S., Pérez-Pérez, R. E. \& Nash III, T. H. 2016. Parmotrema in Mexico. Bibliotheca Lichenologica 110: 323-425.

Eliasaro, S. \& Adler, M. T. 1997 Two new species and new reports in the Parmeliaceae sensu stricto (lichenized Ascomycotina) from Brazil. Mycotaxon 63: 49-55.

Eliasaro, S. \& Adler, M. T. 1998 Rimelia pontagrossensis, a new species in the Parmeliaceae sensu stricto (Lichenized Ascomycotina) from Brazil. Mycotaxon 66: 127-130.

Eliasaro, S. 2001. Estudio taxonómico y florístico sobre las Parmeliaceae sensu stricto (Ascomycota Liquenizados) del Segundo Planalto del Estado de Paraná, Brasil. Buenos Aires. Tesis de Doctor (en Ciencias Biológicas). Universidad de Buenos Aires, Facultad de Ciencias Exactas y Naturales.

Eliasaro, S. 2006. Checklist of lichens and lichenicolous fungi of Paraná (Brazil). Version 1 September 2006. http://www.checklists. de [accessed in October 2008]

Elix, J. A. \& Hale, M. E. 1987. Canomaculina, Myelochroa, Parmelinella, Parmelinopsis and Parmotremopsis, five new genera in the Parmeliaceae (Lichenized Ascomycotina). Mycotaxon 29: $233-244$.

Elix, J. A. 1993. New species in the lichen family Parmeliaceae (Ascomycotina) from Australia. Mycotaxon 47: 101-129.

Elix, J. A. 1994. Parmeliaceae. Flora of Australia 55: 1-360.

Elix, J. A. 1997. The lichen genera Canomaculina and Rimeliella (Ascomycotina, Parmeliaceae). Mycotaxon 65: 475-479.

Elix, J. A. 1998 Clarification of the synonymy and chemistry of Parmotrema zollingeri and related species. Australasian Lichenology 42: 22-27.

Elix, J. A. 2001. Additional lichen records from Oceania 7. Parmeliaceae from Fiji. Australasian Lichenology 48: 34-37.

Elix, J. A. \& Johnston, J. 1988. New species in the lichen family Parmeliaceae (Ascomycotina) from the Southern Hemisphere. Mycotaxon 31: $491-510$

Elix, J. A., Bawingan, P. A. \& Flores, Y. G. 2002. A new species and further new records in the lichen family Parmeliaceae (Ascomycotina) from the Philippines. Mycotaxon 81: 251-256.

Elix, J. A., Fischer, E. \& Killmann, D. 2005. New saxicolous species of Hypotrachyna and Parmotrema (Parmeliaceae) from Rwanda. The Lichenologist 37: 101-104.

Esslinger, T. L. 2008. A cumulative checklist for the lichen-forming, lichenicolous and allied fungi of the continental United States and Canada. North Dakota State University: Fargo, North Dakota. http:// www.ndsu.nodak.edu/instruct/esslinge/chcklst/chcklst7.htm [First Posted 1 December 1997, Most Recent Version (\#14) 8 October 2008].

Fée, A. L. A. 1837. Essai sur les cryptogames des écorces exotiques officinales. 4. Supplément et Revision. Paris et Strassburg.

Ferraro, L. I. 1979. Una nueva especie de Parmeliaceae para el NE Argentino. Hickenia 1: 191-193.

Ferraro, L. I. \& Elix, J. A. 1993. Two new species of Parmeliaceae (Lichenized Ascomycota) from South America. Mycotaxon 49: 405-409.

Ferraro, L. I. \& Elix, J. A. 2000. A new species of Canomaculina (Lichenized Ascomycotina, Parmeliaceae) from Argentina. Mycotaxon 74: $391-394$

Feuerer, T. 1998. E. A. Vainio's contribution to the knowledge of the Parmeliaceae. In: Marcelli, M. P. \& Ahti, T. (eds), Recollecting Edvard August Vainio, p. 47-60. CETESB - Companhia de Tecnologia de Saneamento Ambiental - Estado de São Paulo, São Paulo, Brazil.

Feuerer, T. (ed.) 2008. Checklists of lichens and lichenicolous fungi. Version 1 May 2008. http://www.biologie.uni-hamburg.de/checklists/ lichens/portalpages/portalpage checklists switch.htm [accessed in December 2008]

Feuerer, T., Ahti, T. \& Vitikainen, O. 1998. Lichenological investigations in Bolivia. In: Marcelli, M. P. \& Seaward, M. R. D. (eds). Lichenology in Latin America: history, current knowledge and applications, p. 71-86. CETESB. São Paulo.

Fink, B. \& Fuson, S. C. 1919. Ascomycetes new to the Flora of Indiana. Proceedings of the Indiana Academy of Science: 264-275.

Flakus, A., Oset, M., Rykaczewski, M., Schiefelbein, U. \& Kukwa, M. 2016. Contribution to the knowledge of the lichen biota of Bolivia. 8. Polish Botanical Journal 61: 107-126.

Fleig, M. 1997. Os gêneros Parmotrema, Rimelia e Rimeliella (Lichenes - Ascomycotina, Parmeliaceae) no Rio Grande do Sul, Brasil. Tese (doutorado em Botânica). Instituto de Biociências, Universidade de São Paulo. São Paulo.

Fleig, M. \& Riquelme, I. 1991. Liquens de Piraputanga, Mato Grosso do Sul, Brasil. Acta Botanica Brasilica 5: 3-12.

Fries, E. 1825. Systema Orbis Vegetabilis. Pars I. Plantae homonemeae. Lund.

Galloway, D. J. 1985. Flora of New Zealand, Lichens. Wellington, New Zealand. 
Galloway, D. J. 2007. Flora of New Zealand Lichens. Revised second edition, including lichen-forming and lichenicolous fungi. Volume II: Pannaria - *Zwackhiomyces. Manaaki Whenua Press, Lincoln, New Zeland.

Gaudichaud-Beaupré, M. C. 1826. Voyage autour du monde, exécuté sur les corvettes l'Uranie et la Physcienne, sur les ordres du Cap. L. de Freycinet, en 1817-1820. Botanique. Paris.

Gerlach, A. C. L. 2012. Espécies de fungos liquenizados parmelioides (Parmeliaceae, Ascomycota) em costões rochosos na planície costeira dos estados do Paraná e Santa Catarina. Dissertação (mestrado). Universidade Federal do Paraná.

Gerlach, A. C. L. \& Eliasaro, S. 2014a. Espécies de Parmeliaceae (Ascomycota) ciliadas e sem máculas reticulares em costões rochosos dos Estados do Paraná e de Santa Catarina, Brasil. Hoehnea 41: 321-336.

Gerlach, A. C. L. \& Eliasaro, S. 2014b. Parmotrema marcellii, a new species of Parmeliaceae (lichenized Ascomycota) from Brazil. Brazilian Journal of Botany 37: 597-600.

Gumboski, E. L. \& Eliasaro, S. 2011. Checklist of lichenized fungi of Santa Catarina State (Brazil). Mycotaxon 115: 1-45.

Gyelnik, V. 1931a. Additamenta ad cognitionem Parmeliarum I. Feddes Repertorium specierum novarum regni vegetabilis 29: 149-157.

Gyelnik, V. 1931b. Additamenta ad cognitionem Parmeliarum II. Continuatio prima. Feddes Repertorium specierum novarum regni vegetabilis 29: 273-291.

Gyelnik, V. 1934. Lichenes argentinenses a professore C. C. Hosseus collecti. Feddes Repertorium specierum novarum regni vegetabilis 33: 302-309.

Hale, M. E. 1960. A revision of the South American species of Parmelia determined by Lynge. Contributions from the United States National Herbarium 36: 1-41.

Hale, M. E. 1965. A monograph of Parmelia subgenus Amphigymnia. Contributions from the United States National Herbarium 36: 193-358.

Hale, M. E. 1971. Parmelia permaculata, a new lichen from Alabama and Mexico. Phytologia 21: 425.

Hale, M. E. 1972. Four new species of Parmelia (Lichenes) from India and the Philippines. The Bryologist 75: 97-101.

Hale, M. E. 1974. New combinations in the lichen genus Parmotrema Massalongo. Phytologia 28: 334-339.

Hale, M. E. 1976. A monograph of the lichen genus Parmelina Hale (Parmeliaceae). Smithsonian Contributions to Botany 33: 1-60.

Hale, M. E. 1977. New species in the lichen genus Parmotrema Mass. Mycotaxon 5: 432-448.

Hale, M. E. 1979. How to know the Lichens. The Pictured-Key Nature Series. Dubuque, Iowa: Wm. C. Brown Company Publishers. Dubuque.

Hale, M. E. 1980. Taxonomy and distribution of the Parmelia flaventior group (Lichens: Parmeliaceae). Journal of the Hattori Botanical Laboratory 47: 75-84.

Hale, M. E. 1983. The Biology of Lichens. Third Edition. Edward Arnold, Baltimore.

Hale, M. E. 1990. New species of Parmotrema (Ascomycotina: Parmeliaceae) from Tropical America. Bibliotheca Lichenologica 38: 109-119.

Hale, M. E. \& Fletcher, A. 1990. Rimelia Hale \& Fletcher, a new lichen genus (Ascomycotina: Parmeliaceae). The Bryologist 93: 23-29.

Hale, B. W. \& DePriest, P. T. 1999. Mason E. Hale's list of epithets in the parmelioid genera. The Bryologist 102: 462-544.

Hawksworth, D. L., Ahti, T., Vitikainen, O. \& Crespo, A. 2003. (1595) Proposal to reject the name Parmelia perlata var. olivaria to protect the name Parmotrema pseudoreticulatum (Ascomycota, Lecanorales, Parmeliaceae). Taxon 52: 626-627.
Herre, A. W. C. T. 1906. The foliaceous and fruticose lichens of the Santa Cruz Peninsula, California. Proceedings of the Washington Academy of Sciences 7: 325-396.

Herre, A. W. C. T. 1910. The lichen flora of the Santa Cruz Peninsula, California. Proceedings of the Washington Academy of Sciences 12: 27-269.

Herre, A. W. C. T. 1942. [Review of] A monograph of the genus Parmelia in North America, North of Mexico, by Edward C. Berry. The Bryologist 45: 149-151.

Hue, A. 1895. Lichens de Californie récoltés par M. Diguet et déterminés par M. l'abbé Hue. Journal de Botanique 9: 108-113.

Hue, A. 1899. Lichenes extra-europaei a pluribus collectoribus ad Museum Parisiensi missi. Nouvelles Archives du Muséum d'Histoire Naturelle de Paris, ser. 4(1): 27-220. 6 pl.

Huneck, S. \& Yoshimura, I. (1996) Identification of lichen substances. Springer, Berlin.

Index Fungorum 2009. http://www.indexfungorum.org/Names/Names. asp

Jatta, A. 1909-1911. Flora italica Cryptogama III Lichenes. Tip. Cappelli $\backslash$ Rocca di S. Casciano.

Jungbluth, P. 2006. A família Parmeliaceae (fungos liquenizados) em fragmentos de cerrados do estado de São Paulo. Dissertação (mestrado). Instituto de Botânica da Secretaria de Estado do Meio Ambiente. São Paulo.

Kalb, K. 1982. Lichenes neotropici. Fascikel IV (No. 121-160): 1-12.

Killmann, D. \& Fischer, E. 2005. New Records for the Lichen Flora of Rwanda, East Africa. Willdenowia 35: 193-204.

Krempelhuber, A. 1869. Parmelia perforata Ach., ihre sichere Erkennung und Unterscheidung von verwandten Arten. Flora 52: 219-223.

Krempelhuber, A. 1873. Lichenes Brasilienses. Partic. XIV von E. Warming, Symbolae ad floram Brasiliae cognoscendum. Videnskabelige meddelelser fra den Naturhistoriske forening i Kjöbenhavn 5: $1-35+1$ plate.

Krempelhuber, A. 1876a. Lichenes brasilienses collecti a D. A. Glaziou in provincia brasiliensi Rio Janeiro. Flora (Regensburg) 59: 33-38, 56-63, 70-77, 140-144, 172-176, 217-224, 248-251, 265-271, 316-320, 378-384, 412-416, 417-423, 445-482, 475-482, 511$514,522-529$.

Krempelhuber, A. 1876b. Neue Beiträge zur Flechtenflora Neu-Seelands. Verhandlungen der zoologisch-botanischen Gesellschaft in Wien 26: 447-460.

Krempelhuber, A. 1877. Neue Beiträge zu Afrika's Flechten-flora. Linnaea 7: 135-144.

Krempelhuber, A. 1878. Lichenes, collecti in republica Argentina a Doctoribus Lorentz et Hieronymus. Flora (Regensburg) 61: 433-439, 461-464, 476-480, 492-496, 516-523.

Krempelhuber, A. 1881. Ein neuer Beitrag zur Flechten-Flora Australiens. Verhandlungen der zoologisch-botanischen Gesellschaft in Wien 30: 329-342.

Krog, H. 1974. Parmelia ultralucens, a new lichen species in subgenus Amphigymnia. The Bryologist 77(2): 253-256.

Krog, H. \& Swinscow, T. D. V. 1981. Parmelia subgenus Amphigymnia in East Africa. Bulletin of the British Museum (Natural History) Botany series 9: 143-231.

Krog, H. \& Swinscow, T. D. V. 1983. A new species and new combinations in Parmotrema (Parmeliaceae). The Lichenologist 15: 127-130.

Kukwa, M., Bach, K., Sipman, H. J. M. \& Flakus, A. 2012. Thirty-six species of the lichen genus Parmotrema (Lecanorales, Ascomycota) new to Bolivia. Polish Botanical Journal 57: 243-257.

Kurokawa, S. 1974. Four new species of Parmelia from Brazil. Bulletin of the National Science Museum Tokyo 17: 297-300 + 1 pl. 
Kurokawa, S. 1979. Enumeration of species of Parmelia in Papua New Guinea. In: S. Kurokawa (ed.): Studies on Cryptogams of Papua New Guinea, pp. 125-148. Academic Scientific Book Inc., Tokyo.

Kurokawa, S. 1991. Japanese species and genera of the Parmeliaceae. Journal of Japanese Botany 66: 152-159.

Kurokawa, S. 2001. Taxonomic notes on Parmelia reparata (Parmeliaceae, Lichenes) and the related species. Bulletin of the National Science Museum Tokyo, Ser. B 27: 1-10.

Kurokawa, S. 2003. Checklist of Japanese Lichens. National Science Museum, Tokyo.

Kurokawa, S. \& Lai, M-J. 2001. Parmelioid lichen genera and species in Taiwan. Mycotaxon 77: 225-284.

Lamarck, M. M. de \& de Candolle, A. P. 1805. Flore Francaise. Troisième edition. Vol. II. Paris.

Lamb, I. M. 1939. A review of the genus Neuropogon (Nees \& Flot.) Nyl., with special reference to the Antarctic species. Journal of the Linnean Society, Botany 52: 199-237.

Lamb, I. M. 1963. Index nominum lichenum. Inter annos 1932 et 1960 divulgatorum. Ronald Press Company, New York.

Lamb, I. M. 1977. A conspectus of the lichen genus Stereocaulon (Schreb.) Hoffm. Journal of the Hattori Botanical Laboratory 43: 191-355.

Lendemer, J. C. \& Hewitt, D. A. 2002. A catalogue of the type specimens of lichens in the Herbarium of the Academy of Natural Sciences of Philadelphia. Proceedings of the Academy of Natural Sciences of Phyladelphia 152: 173-204.

Lindsay, L. W. 1866. Observations on New Zealand Lichens. Transactions of the Linnean Society of London 25: 493-560.

Louwhoff, S. H. J. J. \& Elix, J. A. 1998. The lichen family Parmeliaceae (Ascomycotina) on Lord Howe Island, Australia. Mycotaxon 68: 429-463.

Louwhoff, S. H. J. J. \& Elix, J. A. 1999. Parmotrema and allied lichen genera in Papua New Guinea. Bibliotheca Lichenologica 73: 1-152.

Louwhoff, S. H. J. J. \& Elix, J. A. 2000. Five new species in the lichen family Parmeliaceae (Ascomycotina) from Grande Terre, New Caledonia. Mycotaxon 75: 195-203.

Lücking, R., Hodkinson, B. P. \& Leavitt, S. D. 2017a ('2016'). The 2016 classification of lichenized fungi in the Ascomycota and $\mathrm{Ba}$ sidiomycota-Approaching one thousand genera. The Bryologist 119: 361-416.

Lynge, B. 1914. Die Flechten der ersten Regnellschen Expedition. Die gattungen Pseudoparmelia gen. nov. und Parmelia Ach. Arkiv för Botanik 13(13): 1-172.

Lynge, B. 1924. On some South American lichens of the Genera Parmelia, Candelaria, Theloschistes and Pyxine. Nyt Magazin for Naturvidenskaberne 62: 83-97.

Mackay, J. T. 1836. Flora Hibernica, comprising the Flowering Plants, Characeae, Musci, Hepaticae, Lichenes and Algae of Ireland. Dublin, London \& Edinburgh

Magnusson, A. H. \& Zahlbruckner, A. 1944. Hawaiian Lichens. II. The Families Lecideaceae to Parmeliaceae. Arkiv för Botanik 31A(6): $1-109$.

Malcolm, W. M. \& Galloway, D. J. 1997. New Zealand Lichens. Checklist, Key, and Glossary. Museum of New Zealand Te Papa Tongarewa, Wellington.

Marcelli, M. P. 1991. Aspects of the foliose lichen flora of the southern-central coast of São Paulo State, Brazil. In: Galloway, D. J. (ed.). Tropical Lichens: Their Systematics, Conservation, and Ecology. Systematics Association Special Volume n ${ }^{\circ} 43$ : 151-170. Clarendon Press, Oxford.

Marcelli, M. P. 1992. Ecologia liquênica nos Manguezais do Sul-Sudeste Brasileiro. Bibliotheca lichenologica 47: I-VII + 1-288 + 31 photos in 22 pages.
Marcelli, M. P. 2008. Checklist of lichens and lichenicolous fungi of Brazil. Preliminary version 1 May 2008. http://www.biologie. uni-hamburg.de/checklists/lichens/south-america/ brazil_1.htm

Marcelli, M. P. \& Ahti, T. (eds) 1998. Recollecting Edvard August Vainio. São Paulo, CETESB.

Marcelli, M. P. \& Benatti, M. N. 2008. Espécies de Parmotrema (Parmeliaceae, Ascomycetes liquenizados) com rizinas dimórficas do litoral centro-sul do Estado de São Paulo. Hoehnea 35: 171-183.

Marcelli, M. P. \& Benatti, M. N. 2010. Espécies de Parmotrema (Parmeliaceae, Ascomycota) do litoral centro-sul do Estado de São Paulo II. Grupos químicos norstíctico e salazínico. Acta Botanica Brasilica 24: 153-168.

Marcelli, M. P. \& Ribeiro, C. H. 2002. Twenty-one new species of Parmeliaceae (lichenized fungi) from southeastern Brazil. Mitteilungen aus dem Institut für Allgemeine Botanik Hamburg 30-32: 125-155.

Marcelli, M. P., Jungbluth, P., Benatti, M. N., Spielmann, A. A., Canêz, L. S., Cunha, I. P. R. \& Martins, M. F. N. 2007. Some new species and combinations of Brazilian lichenized fungi. Bibliotheca Lichenologica 96: 209-227.

Massalongo, A. 1860. Esame comparativo di alcuni generi di licheni. Atti dell'Istituto Veneto di scienze, lettere ed arti 5(3): 247-267, 313-337.

Mata García, L. B. 1994. Rimelia bonplandii, a new lichen species (Ascomycotina: Parmeliaceae). The Bryologist 97: 432-433.

Merrill, G. K. 1909. Lichen notes, no. 9: Parmelia latissima Fée and two commonly associated species. The Bryologist 12: 29-31.

Meyen, J. \& Flotow, J. 1843. Lichenes. In: Meyen, J. \& Flotow, J. 1843. Lichenes. Novorum Actorum Academiae Caesareae Leopoldino-Carolinae Naturae Curiosorum 19(Suppl 1): 209-232.

Micheletti, A. C., Beatriz, A., Lima, D. P., Honda, N. K., Pessoa, C.Ó, Moraes, M. O., Lotufo, L. V., Magalhães, H. I. F. \& Carvalho, N. C. P. 2009. Constituintes químicos de Parmotrema lichexanthonicum Eliasaro \& Adler - isolamento, modificações estruturai e avaliação das atividades antibiotic e citotóxica. Química Nova 32: $12-20$.

Moon, K. H., Kurokawa, S. \& Kashiwadani, H. 2001. The genus Rimelia (Lichens) from the Hawaiian Islands. Journal of Japanese Botany 76: $321-328$

Moore, B. J. 1968. The Macrolichen Flora of Florida. The Bryologist 71: 161-267

Morton, J. B., Bentivenga, S.P \& Wheeler, W. W. 1993. Germ plasm in the International Collection of Arbuscular and Vesicular-arbuscular Mycorrhizal Fungi (INVAM) and procedures for culture development, documentation and storage. Mycotaxon 48: 491-528.

Müller Argoviensis, J. 1880. Lichenes Africae occidentalis a cll. Dr. Pechuel-Loesche et Soyaux e regione fluminis Quillu et ex Angola missi, in Mus. bot. reg. berolinensi servati. Linnaea 9: 31-48.

Müller Argoviensis, J. 1883. Lichenologische Beiträge 17. Flora (Regensburg) 66: 17-25, 45-48, 75-80.

Müller Argoviensis, J. 1886. Lichenologische Beiträge 23. Flora (Regensburg) 69: 124-128.

Müller Argoviensis, J. 1888. Lichenologische Beiträge 27. Flora (Regensburg) 71: 17-25, 44-48.

Müller Argoviensis, J. 1891a. Lichenologische Beiträge 35. Flora (Regensburg) 74: 371-382.

Müller Argoviensis, J. 1891b. Lichenes Schenckiane a cl. Dr. H. Schenck, Bonnensi, in Brasiliae orientalis prov. Santa Catharina, Parana, Rio de Janeiro, Minas Geraes et Pernambuco lecti. Hedwigia 30: 219-234.

Müller Argoviensis, J. 1892. Lichenes exotici Herbarii Vindobonensis - I. Lichenes in Australia et in ejus vicinitate lecti. Annalen des K. K. naturhistorischen Hofmuseums 7: 302-305.

Müller Argoviensis, J. 1893. Lichenes, in Durand, Th. \& Pittier, H., Primitiae florae Costaricensis. Séconde énumération. Bulletin de la Société royale de Botanique de Belgique 32: 122-173. 
Müller Argoviensis, J. 1894. Lichenes usambarenses. Engler's Botanische Jahrbücher 20: 238-298.

Nash III, T. H. \& Elix, J. A. 2002a. Canomaculina. In: Nash III, T. H., Ryan, B. D., Gries, C. \& Bungartz, F. (eds). Lichen Flora of the greater Sonoran Desert Region. Volume 1. Lichens Unlimited, Arizona State University, Tempe, Arizona, USA.

Nash III, T. H. \& Elix, J. A. 2002b. Parmotrema. In: Nash III, T. H., Ryan, B. D., Gries, C. \& Bungartz, F. (eds). Lichen Flora of the greater Sonoran Desert Region. Volume 1. Lichens Unlimited, Arizona State University, Tempe, Arizona, USA.

Nash III, T. H. \& Elix, J. A. 2002c. Rimelia. In: Nash III, T. H., Ryan, B. D., Gries, C. \& Bungartz, F. (eds). Lichen Flora of the greater Sonoran Desert Region. Volume 1. Lichens Unlimited, Arizona State University, Tempe, Arizona, USA.

Nylander, W. 1869. Lichenes in Brasilia a Glaziou collecti. Flora (Regensburg) 52: 117-126.

Nylander, W. 1875. Liste des lichens recueilles par M. G. de 1'Isle, aux îles Saint-Paul et d'Amsterdam et description des espèces nouvelles. Comptes Rendus Hebdomadaires des Séances de l'Académie. Séances Académie des Sciences [Paris] 81: 725-726.

Nylander, W. 1878. Addenda nova ad Lichenographiam Europaeam. Continuatio tricesima. Flora (Regensburg) 61: 241-249.

Nylander, W. 1885. Parmeliae exoticae novae. Flora (Regensburg) 68: $605-615$.

Nylander, W. 1886. Lichenes Insulae Sancti Pauli. Flora (Regensburg) 69: 318-322.

Nylander, W. 1900. Lichenes Ceylonenses et Additamentum ad Lichenes Japoniae. Acta Societatis Scientiarum Fennicae 26(10): 1-33.

Ohmura, Y., Kashiwadani, H. \& Moon, K. H. 2012. Recovery of macrolichen flora in the Imperial Palace Ground, Tokyo, Japan. Journal of Japanese Botany 87: 51-57.

Orange, A., James, P. W. \& White, F. J. 2001. Microchemical methods for the identification of lichens. British Lichen Society.

Osorio, H. S. 1970. Lichens from Cantera, South Paraguay. Comunicaciones Botánicas del Museo de Historia Natural de Montevideo 4(50): 1-3.

Osorio, H. S. 1972. Contributions to the Lichen Flora of Uruguay. VII. A preliminary catalogue. Comunicaciones Botánicas del Museo de Historia Natural de Montevideo 4(56): 1-46.

Osorio, H. S. 1976. Contribution to the Lichen Flora of Argentina VIII. Lichens from Punta Lara, Buenos Aires Province. The Bryologist 79: $358-360$.

Osorio, H. S. 1977a. Contribution to the Lichen Flora of Brazil. II. Lichens from Guarapuava, Paraná State. Dusenia 10: 101-102.

Osorio, H. S. 1977b. Contribution to the Lichen Flora of Brazil III. Lichens from Western Paraná. Acta Biologica Paranaense 6: 3-7.

Osorio, H. S. 1979. Contribution to the lichen flora of Uruguay XI. Lichens from Arazati, San Jose Department. The Bryologist 82: $472-473$.

Osorio, H. S. 1981. Contributions to the lichen flora of Argentina XIII. Lichens from Misiones Province. Communicaciones Botanicas del Museo de Historia Natural de Montevideo 4(63): 1-18.

Osorio, H. S. 1992a. Contribution to the Lichen Flora of Brazil. XXIX. Lichens from Ponta Porá, Mato Grosso do Sul. Comunicaciones Botánicas del Museo de Historia Natural de Montevideo 5(98): 1-6.

Osorio, H. S. 1992b Contribución a la flora liquénica del Uruguay. XXV. Líquenes publicados entre 1972 a 1991. Anales del Museo Nacional de Historia Natural de Montevideo 2a Serie, Vol. 8: 43-70.

Osorio, H. S. 1995 Contribution to the Lichen Flora of Uruguay. XXVIII. Lichens from Southern Rocha. Comunicaciones Botánicas del Museo de Historia Natural de Montevideo 5(103): 1-12.

Osorio, H. S. 1997. Contribution to the Lichen Flora of Brazil. XXXIV. Lichens from Lagura, Santa Catarina State. Comunicaciones Botánicas del Museo de Historia Natural de Montevideo 6(108): 1-4.
Osorio, H. S. 2003. Contribution to the lichen flora of Uruguay. XXXVIII. Some collections from Eastern Uruguay. Comunicaciones Botánicas del Museo de Historia Natural de Montevideo 6(126): 1-11.

Park, Y. S. 1990. The Macrolichen Flora of South Korea. The Bryologist 93: $105-160$.

Purvis, O. W., Coppins, B. J., Hawksworth, D. L., James, P. W. \& Moore, D. M. (eds) 1992. The Lichen Flora of Great Britain and Ireland. London: Natural History Museum.

Räsänen, V. 1938. Beiträge zur Flechtenflora Südamerikas. Uruguayische Flechten, gesammelt von W. G. Herter. Mit Berücksichtigung von Material aus anderen Ländern. Revista Sudamericana de Botánica 5(3-4): 65-72.

Räsänen, V. 1944. Lichenes novi I. Annales Botanici Societatis Zoologicae Botanicae Fennicae Vanamo 20(3): 1-34.

Räsänen, V. 1947. Lichenes novi III. Archivum societatis zoologicae botanicae fennicae Vanamo 2: 45-51.

Ribeiro, C. H. 1998. A família Parmeliaceae (Ascomycota liquenizados) em regiões montanhosas dos estados de Minas Gerais, Rio de Janeiro e São Paulo. Dissertação (mestrado em Botânica). Instituto de Biociências, Universidade de São Paulo.

Sambo, M.C 1930. Licheni della Patagonia e di altre regioni dell' Argentina raccolti dai missionari salesiani. Contributi Scientifici delle Missioni Salesiane del Beato Don Bosco, Torino 6: 1-73, 2 maps, 9 pl.

Sammy, N. 1985. Register of lichen type specimens and chemistry of lichen type specimens in the British Museum and Geneva. Western Australian Herbarium Research Notes 11: 41-52.

Singh, K. P. 1980. A new species of Parmelina from India. The Bryologist 83: 533-534.

Sipman, H. J. M. 1999. Checklist of the lichens of the Guianas. http:// botany.si.edu/BDG/aboutlich.html

Sipman, H. J. M. 2005. Mason Hale's key to Parmotrema, revised edition: key to wide-lobed parmelioid species occurring in Tropical America (genera Canomaculina, Parmotrema, Rimelia, Rimeliella). Botanischer Garten und Botanisches Museum Berlin-Dahlem, Freie Universität Berlin. http://www.bgbm.org/sipman/keys/Neoparmo. htm [accessed in April 2009]

Sipman, H. J. M. \& van Aubel, R. J. M. T. 1992. New Parmeliaceae (Lichenes) from the Guianas and surroundings. Mycotaxon 44: $1-12$.

Smith, C. W. 1993. Notes on Hawaiian Parmelioid Lichens. The Bryologist 96: 326-332.

Spielmann, A. A. 2005. A família Parmeliaceae (fungos liquenizados) nos barrancos e peraus da encosta da Serra Geral, Vale do Rio Pardo, Rio Grande do Sul, Brasil. Dissertação (mestrado). Instituto de Botânica da Secretaria de Estado do Meio Ambiente. São Paulo..

Spielmann, A. A. 2006. Checklist of lichens and lichenicolous fungi of Rio Grande do Sul (Brazil). Caderno de Pesquisa Série Biologia (Santa Cruz do Sul) 18(2): 7-125.

Spielmann, A. A. \& Marcelli, M. P. 2006. Preliminary world-wide key to the lichen genus Rimelia (Parmeliaceae, lichenized Ascomycota) In: Anais da Primeira Reunião Brasileira de Estudos Liquenológi$\cos$ (1a REBEL). São Paulo - SP: Instituto de Botânica (Grupo de Estudos Liquenológicos, GEL-IBt), v.1: 59-69.

Spielmann, A. A. \& Marcelli, M. P. 2009. Parmotrema s.1. (Parmeliaceae, lichenized Ascomycota) from Serra Geral slopes in central Rio Grande do Sul State, Brazil. Hoehnea 36: 551-595.

Stafleu, F. A., Bonner, C. E.B, McVaugh, R., Meikle, R. D., Rollins, R. C., Ross, R., Schopf, J. M., Schulze, G. M., de Vilmorin, R. and Voss, E. G. (eds) 1972. International Code of Botanical Nomenclature, adopted by the Eleventh International Botanical Congress, Seattle, August 1969.

Stirton, J. 1877. Additions to the lichen flora of South Africa. Transactions of the Glasgow Society of Field Naturalists 5: 211-220.

Stirton, J. 1877-1878. On certain lichens belonging to the genus Parmelia. Scottish Naturalist 4: 200-203, 252-254, 298-299. 
Streimann, H. 1986. Catalogue of the Lichens of Papua New Guinea and Irian Jaya. Bibliotheca Lichenologica 22: 1-145.

Swinscow, T. D. V. \& Krog, H. 1988. Macrolichens of East Africa. British Museum (Natural History), London.

Tavares, C. N. 1945. Contribuição para o estudo das Parmeliáceas Portuguesas. Portugaliae Acta Biologica, série B. 1(1-2): 1-210.

Taylor, T. 1847. New lichens, principally from the Herbarium of Sir William J. Hooker. The London Journal of Botany 6: 148-197.

Taylor, C. J. 1967. The lichens of Ohio. Part I. Foliose Lichens. The Ohio Biological Survey. Biological Notes No. 3; 1-151

Tenorio, L. U., Sipman, H. J. M. \& Lücking, R. 2002. Preliminary checklist of lichens from Costa Rica. Version 1.2 (June 2002). http://www.fieldmuseum.org/ticolichen/checklist.html [accessed in April 2009]

Turland, N. J., Wiersema, J. H., Barrie, F. R., Greuter, W., Hawksworth, D. L., Herendeen, P. S., Knapp, S., Kusber, W.-H., Li, D.-Z., Marhold, K., May, T. W., McNeill, J., Monro, A. M., Prado, J., Price, M. J. \& Smith, G. F. (eds) 2018. International Code of Nomenclature for algae, fungi, and plants (Shenzhen Code) adopted by the Nineteenth International Botanical Congress Shenzhen, China, July 2017. Regnum Vegetabile 159. Glashütten: Koeltz Botanical Books.

Vainio, E. A. 1890. Étude sur la classification naturelle et la morphologie des Lichens du Brésil. Pars prima. Acta Societatis pro Fauna et Flora Fennica 7(1): I-XXIX, 1-247.

Vainio, E. A. 1909a. Lichenes. In: Schmidt, J. Flora of Koh Chang. Contributions to the knowledge of the vegetation of the Gulf of Siam. Part. IX. Botanisk Tidsskrift 29: 104-152.

Vainio, E. A. 1909b. Lichenes insularum Philippinarum, I. Philippine Journal of Science C, Bot., IV, 5: 651-662.

Vainio, E. A. 1918. Lichenes ab A. Yasuda in Japonia collecti. Botanical Magazine [Tokyo] 32: 154-163.

Vareschi, V. 1962. Resultados liquenológicos de excursiones efectuadas en Venezuela 2. Acerca del género Parmelia en Venezuela. Acta Biologica Venezuelica 3(14): 201-232.

Vareschi, V. 1973. Resultados lichenologicos de excursiones effectuadas en Venezuela. No. 3. Catalogo de los líquenes de Venezuela. Acta Botánica Venezuelica 8(1-4): 177-245.

Wallroth, F. W. 1831. Flora cryptogamica Germaniae. Norimbergae.
White, F. J. \& James, P. W. 1985. A new guide to microchemical tecniques for the identification of the lichen substances. British Lichen Society Bulletin 57(suppl.): 1-41.

Wiggins, I. L. 1962. Albert William Christian Theodore Herre (18681962). The Bryologist 65: 268-277.

Winnem, B. 1975. Parmelia subgenus Amphigymnia in Ethiopia. Norwegian Journal of Botany 22: 139-166.

Zahlbruckner, A. 1902. Studien über brasilianische Flechten. Sitzungsberichte der kaiserlichen Akademie der Wissenschaften Wien, Mathematisch-Naturwissenschaftlichen Classe 111, Abtheilung 1: $357-432+$ tafel I-II.

Zahlbruckner, A. 1904. Lichenes a cl. Damazio in montibus Serra do Ouro Preto Brasiliae lecti in herb. Barbey-Boissier asservati. Bulletin de L'Herbier Boissier Ser. 2, 4: 134-136.

Zahlbruckner, A. 1905. Lichenes, a cl. Damazio in Brasilia lecti. II. Bulletin de L'Herbier Boissier Ser. 2, 5: 539-543.

Zahlbruckner, A. 1907. Lichenes (Flechten). Spezieller Teil, p. 49-249. In: Engler, A. \& Prantl, K. (eds). Die natürlichen Pflanzenfamilien, sect. 1. 1. Leipzig.

Zahlbruckner, A. 1908. Neue Flechten, IV. Annales Mycologici 6: 129-134.

Zahlbruckner, A. 1909. Lichenes. In: Schiffner, V. (ed.). Ergebnisse der botanischen Expedition der Kaiserlichen Akademie der Wissenschaften nach Südbrasilien 1901. Band II: Tallophyta und Bryophyta. Denskschriften der Mathematsch-Naturwissenschaftlichen Klasse der Kaiserlichen Academie der Wissenschaften 83: 87-211.

Zahlbruckner, A. 1926. Afrikanische Flechten (Lichenes). Botanische Jahrbücher für Systematik, Pflanzengeschichte und Pflanzengeographie 60: 468-552.

Zahlbruckner, A. 1928. Neue und ungenügend beschriebene javanische Flechten. Annales de Cryptogamie Exotique 1: 109-212.

Zahlbruckner, A. 1930a. Catalogus lichenum universalis. Band VI. Leipzig: Gebrüder Borntraeger..

Zahlbruckner, A. 1930b. Lichenes (Übersicht über sämtliche bisher aus China bekannten Flechten). In: Handel-Mazetti,H: Symbolae sinicae. Botanische Ergebnisse der Expedition der Akademie der Wissenschaften in Wien nach Südwest-China 1914-1918. III. J. Springer, Wien.

Zahlbruckner, A. 1934. Catalogus lichenum universalis. Band IX. Gebrüder Borntraeger, Leipzig. 